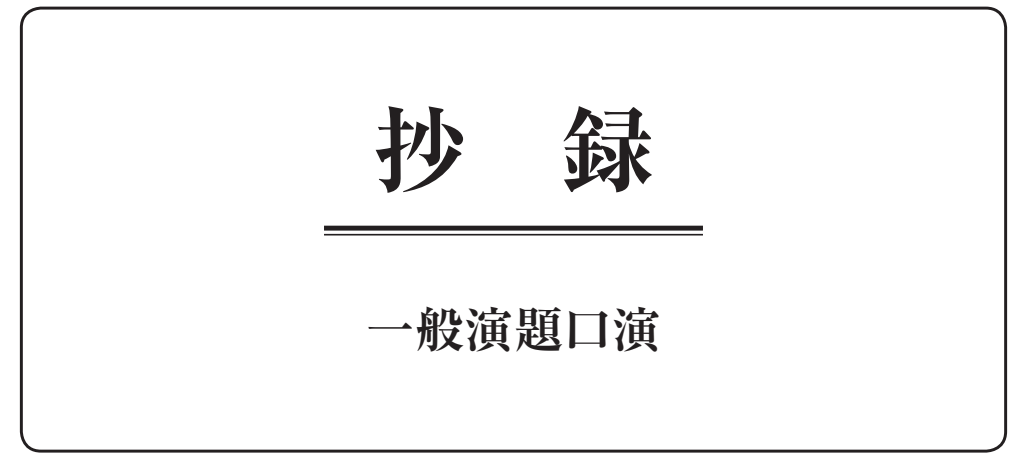




\section{1-1-1ＩGFシグナルの振動と安定化が細畇の運命を決定 する}

伯野 史彦、増田 正人 1 、渡邊 聡 ${ }^{2}$ 、高橋 伸一郎 ${ }^{1}$

${ }^{1}$ 東京大学 大学院農学生命科学研究科 応用動物科学専攻、 ${ }^{2}$ 東京大学 数理科 学研究科 数理科学専攻

インスリン様成長因子(IGF)は、正常な動物の成長・発達に必須の役割を果た しているっインスリンの血中濃度が一過的に増加するのに対して、IGFの血中 濃度に日内変動は観察されず、インスリンに比較すると常時高濃度に保たれて いることが知られている。IGFが常時存在する生体内で、IGFシグナルがどの ように活性化されているかは全く分かっていない。そこで今回、IGFシグナル のネガティブフィードバック機構を組み达んだ数理モデルを構筑し、IGFが常 時存在する状態でのIGFシグナルをシミュレーションした。その結果、IGF濃 度が低い場合にはIGFシグナルは時間経渦とともに上下動する、いわゆる振 動を繰り返すが、IGF濃度がある一定值を越えると IGFシグナルは安定的に収 束して一定值となることが予想された。そこで筋芽細胞L6を、血清除去した 後、種々の濃度の IGF-Iで刺激し、IGFシグナルの活性ダイナミクスを数日間 にわたって経時的に追跡した。その結果、 $1 \mathrm{ng} / \mathrm{ml}$ の IGF-Iで刺激した細胞で は、IGF シグナルの活性が増加、減少を繰り返し、振動することが碓認され た。これに対して、100 ng/mlのIGF-Iで刺激した場合には、IGFシグナルの 振動は観察されなかった。また、IGFシグナルが振動しているIGF濃度では筋 分化が誘導され、IGFシグナルが安定化しているIGF 濃度では細胞增殖が促進 された。これら一連の結果から、IGFの一定濃度を境にIGFシグナルは振動 安定化を状態遷移し、これが增殖と分化という細胞の運命決定に重要な役割を 果たしていることが明らかとなった。

\section{1-1-3 AFF3は中間肢異形成症の原因遺伝子である}

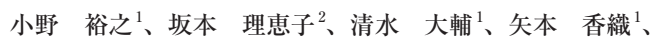

才津 浩智 ${ }^{3}$ 、西村 玄 ${ }^{4}$ 、緒方 勤 $^{1}$

${ }^{1}$ 浜松医科大学 小览科、 ${ }^{2}$ 熊本大学 小児科、 ${ }^{3}$ 浜松医科大学 医化学、 ${ }^{4}$ 埼玉医 科大学病院 難病センター

【背景】中間肢異形成症は、中間肢骨短縮を中核症状とする遺伝的・臨床的異 啠性の高い骨系統疾患である。このうち、脛骨低形成と腓骨欠損を伴う中間 肢異形成症において、AFF3 含む 2 1 11 領域の微小欠失が報告された。さ に、モデルマウスに扔いて、Aff3の部分欠失が脛骨と腓骨の重篤な形成不全を 引き超すことが報告された。これらの報告から、AFF3のハプロ不全と中間肢 異形成症発症の関連が示唆されたが、AFF3が中間肢異形成症の責任遺伝子で あることを支持する直接的な証拠は得られていない。今回、われわれは、片 側の合趾症を伴う中間肢異形成の女肾に执いて、AFF3の de novo病的ミスセン スバリアントを同定したので報告する。【症例】非血族婚の両親（父 $175 \mathrm{~cm}$ 、 母 $154 \mathrm{~cm})$ から、在胎 38 週 0 日、身長 $45.0 \mathrm{~cm}(-1.48 \mathrm{SD})$ 、体重 $2422 \mathrm{~g}(-0.89$ $\mathrm{SD})$ 、頭囲 $32.0 \mathrm{~cm}(-0.74 \mathrm{SD})$ で出生した女児である。左第 $4 \cdot 5$ 趾の合趾症が 認められ、画側腎低形成を合併していた。生後8 か月時には、四肢短縮型低身 長が㩆著となり、身長 $63.3 \mathrm{~cm}(-2.35 \mathrm{SD})$ 、体重 $6845 \mathrm{~g}(-1.34 \mathrm{SD})$ であった。 骨レントゲンに㧠いて、両側中間肢骨短縮、左第 4 中足骨の低形成、左第 $4 \cdot 5$ 趾の合趾症が認められたことから、左合趾症を伴う中間肢異形成症と診断され た。[遺伝学的解析】 全エクソーム解析に执いて、AFF3にde novo の c.697G $>$ A, p.(Ala233Thr)がヘテロ接合性に同定された。このバリアントは、データベー スに登録されておらず、ACMG criteriaで、 likely pathogenic と判定された。 【まとめ】上記の成績は、2q11.2領域の微小久失例とモデルマウスの報告と合 わせ、AFF3が中間肢異形成症の原因遺伝子であることを強く示す。

\section{1-1-5 ヒトにおいて膵 $\beta$ 細胞量減少は $\alpha$ 細胞の ARX発現 を減弱させる}

藤田 有可里 ${ }^{1,2}$ 、小澤 純二 ${ }^{1,3}$ 、米田 祥 ${ }^{1}$ 、福井 健司 ${ }^{1} 、$ 江口 英利 ${ }^{4} 、$ 岩橋 博見 ${ }^{1,3}$ 、下村 伊一郎 ${ }^{1}$

${ }^{1}$ 大阪大学 大学院医学系研究科 内分泌 - 代謝内科、 ${ }^{2}$ 大阪大学 大学院医学系 研究科 総合地域医療学寄附講座、 ${ }^{3}$ 大阪大学大学院医学系研究科 糖尿病病 態医療学寄附講座、 ${ }^{4}$ 大阪大学 大学院医学系研究科消化器外科学

【背景】これまでに動物モデルの膵島細胞において転写因子の異所性発現や欠 失に上り脱分化や他の膵島細胞への分化転換がみられることが報告されてい るが、生理的環境下でのヒト肢島におけるそれらの発生要因は明らかとなっ ていない。【目的】ヒ下滕島細胞が脱分化や分化転換を起こす要因を明らかと する。【対象・方法】対象は当院消化器外科にて滕切除術を施行された血梼 降下薬非使用の 34 名。摘出膵標本に含まれる正常部の $a$ 細胞における転写因 子 Aristaless-related homeobox gene (ARX) 陽性率と各種臨床指標や膵島組 織学的所見との関連を検討した。結果】 $a$ 細胞のARX発現率は全体で79.8 $\pm 8.4 \%$ であった。耐糖能ステージ間での差抢よび年齢、BMI、HbAlc、空 腹時血糖、空腹時Cペプチド、Cペプチドインデックス (CPI) との有意な 相関関係を認めなかったが、 $\beta$ 細胞面積と有意な正相関を認めた $(\mathrm{r}=0.34$ $\mathrm{p}=0.047$ )。また、CPI1.0未満では 1.0 以上に比べ有意に陽性率が低值であった $(731 \pm 130 \%$ 対 $812 \pm 66 \%, p=0.031) \alpha a$ 紐胞面皘や $\alpha / \beta$ と 仕有意な相 関関倸は認められなかった。【考察】膵 $\alpha$ 細胞の ARX陽性率は $\beta$ 細胞量の減少 やインスリン分泌能の低下に伴い減少した。 $\beta$ 細胞量やインスリン分泌能の低 下が $a$ 細胞の脱分化や分化転換を誘発している可能性がある。
01-1-2 From bedside to the bench: 新規ホモ接合性 IGF1R変異はGH・IGF-I・インスリン感受性低下 を示す

藤本 正伸 ${ }^{1,2} 、$ Maystadt Isabelle ${ }^{3}$, Chang Ching-Fang ${ }^{2}$ 、 Dixit Manisha 、Dauber Andrew ${ }^{5}$, Yakar Shoshana $、{ }^{4}$ Hwa Vivian ${ }^{2}$ ${ }^{1}$ 鳥取大学 医学部 周産期 - 小児医学分野、 ${ }^{2}$ Cincinnati Children's Hospital Medical Center, USA、 ${ }^{3}$ Institut de Pathologie et de Genetique, Belgium. ${ }^{4}$ New York University College of Dentistry, USA、 ${ }^{5}$ Children's National Medical Center, USA

【目的】ヘテロ接合性インスリン様成長因子受容体I型(IGF1R) 遺伝子異常症 は, 子宮内登育逑延(IUGR)及び, 出生後の成長障害々関連がある, 現在までに, ホモ接合性IGF1R 遺伝子変異を有する2家系が報告されている，私達は，低身 長姉弟例において全エクソーム解析を実施し, 新規ホモ接合性IGF1R:p.A711 E714del遺伝子異常を認めた。同変異による成長・代謝への影響を評価す る.【方法】同変異に相当する遺伝子変異をCRISPR/Cas9を用いて C57BL/6J マウスに導入し、表現型解析を実施した。また，患者及びマウス由来線維芽組 胞を用いてIGF1Rの登現及び IGF-I・インスリンへの反底を評価した【結 果】近親婚両親から生まれた姉弟は, IUGR と成長障害(姉, 9歳, HtSDS -6.2SD 弟,7歳, HtSDS - 4.5SD) を認めた. 精神発達道滞, 感音性難聴, 小頭症, 骨密度低 下, GH・IGF-I高值を認めた。 ホモ接合性(Ho) Igflr knock-in (KI) マウスは, 野 生型比 $56 \%$ の体重, $80 \%$ の体長 $(8$ 週齢) と成長障害を認めた。血清 GH・IGF-I 濃度は、患者及びHoマウスで著明な上暴を認めた，患者及びHoマウス線維芽 紐胞では, IGF-I及びインスリンへの感受性低下を認めたが, siRNAを用い変 異IGFIRをknockdown した場合改善を認めた。【結論】私達は, 生存可能な木 乇接合性Igf1r KI マウスを樹立し，その表現型及び内分泌学的特徴は患者表現 型に類似していた. Knockdown実験から, 変異IGF1Rは優势阻害効果により IGF-I及びインスリンの感受性低下に寄与すると考えられた。

\section{1-1-4＼cjkstart膵 $\alpha$ 細胞におけるSirt1 によるグルカゴン分泌制御 機構}

菊池 司 ${ }^{1} 、$ 小林 雅樹 ${ }^{1}$ 、佐々木 努 2 、北村 忠弘

${ }^{1}$ 群馬大学 生体調節研究所 代謝シグナル解析分野、 ${ }^{2}$ 京都大学大学院 農学研 究科食品生物化学専攻 栄養科学分野

【目的】糖尿病ではグルカゴン分泌異常が見られるが、その発症メカニズムは 解明されていない。NAD+依存性の脱アセチル化醅素 $\operatorname{Sirt1}$ は膵 $\beta$ 細胞におい てインスリン分泌と細胞增殖を制御するが、その発現レベルは $\beta$ 緗胞よりも膵 $a$ 細胞で高い。予備検討の結果、糖尿病モデルマウスのラ氏島ではSirt1 の発 現低下が確認された。そこで「糖毒性下のSirt1の発現低下がグルカゴン分泌 異常を引き起こす」という仮説を立て、その検証を試みた。

【方法】 $a$ 細胞特異的Sirt1ノックアウト（KO） マウスを作製し、表現型を解 析した。また $\alpha$ 細胞株を用いてSirt1 阻害郕の添加䒠験を行った

【結果】KOマウスではコントロールと比べて $a$ 細胞量が有意に増加し、自由 掑食時の血中グルカゴン濃度も增加傾向を示した。高インスリンクランプを用 いて低血糖誘導を行うと、KOマウスでは誘導早期には血中グルカゴン濃度の 低下が見られ、内因性の糖产生も低下したが、誘導後期にはそれが逆転した。 $a$ 細胞株に対するSirt1 阻害剤添加ではグルカゴン分泌の抑制が見られた。ま たUCP2 遺伝子の発現増加が見られ、ATP合成阻害を介したグルカゴン分泌 抑制が示唆された

【考察】 $a$ 細胞に扔いて Sirt1 は細胞の分化増殖を抑制する一方で、UCP2の発 現抑制を介して低血糖誘道早期のグルカゴン分泌は促進することが示唆され た。またKOマウスで見られた表現型は、糖尿病で見られる低血糖時のグルカ ゴン分泌不全と平常時の過分泌という所見と合致しており、Sirt1の発現低下 がグルカゴン分泌異常の原因の一つとなる可能性が示された。今後、セルソー 夕ーを用いて遺伝子改変マウスから $a$ 細胞を単離回収し、さらに詳細なメカニ ズムを検討する予定である。

\section{1-1-6 絶食に伴う代謝変化に対するグルカゴンの生理的 役割}

小林 雅樹 ${ }^{1}$ 菊池 司 ${ }^{1} 、$ 和田 恵梨 ${ }^{1} 、$ 河野 大輔 ${ }^{1} 、$ 林 良敬 ${ }^{2} 、$ 佐々木 努 1 , 扎村 忠弘 ${ }^{1}$

${ }^{1}$ 群馬大学 生体調節研究所 代謝シグナル解析分野、 ${ }^{2}$ 名古屋大学 環境医学研 究所、 ${ }^{3}$ 京都大学大学院 農学研究科

グルカゴンは糖新生とグリコーゲン分解を促進することで血糖值を上昇させる 血糖調節ホルモンとして知られている。しかし近年、グルカゴンのアミノ酸代 謝調節作用も知られるようになりつつあり、グルカゴンの分泌変動については 糖代謝調節以外の生理作用も考慮に入れた解析が必要である。そこで本研究 では、個体の代謝が経時的に変化をする絶食下に打ける血中グルカゴン濃度の 変化と、他の代謝パラメーターとの関わりについて解析した。野生型マウスに おいて血中インスリン濃度と肝グリコーゲン含量は絶食開始後より低下したの に対し、グルカゴンはインスリンの低下から遅れて増加した。さらにグルカゴ ンノックアウト (Geg KO) マウスにおいても、絶食により肝グリコーゲン含量 はコントロールマウスと同様に低下した。絶食開始前のGcg KOマウスのアミ ノ酸代謝関連遺伝子発現は低く、血中アミノ酸濃度は著しく高值であった。し かし絶食後、アミノ酸代謝関連遺伝子の多くは発現が増加し、血中アミノ酸は コントロールマウスと同様のパターンで変化した。絶食期間中にGcg KOマウ スの血糖值はコントロールマウスより低下することはなく、コントロールマウ スと同程度の糖新生能を維持していたことから、インスリンの低下や交感神経 系など他の因子により血糖調節能は代償されていると考えられる。一方で Gcg KOマウスは高アミノ酸血症を示すことから、グルカゴンがアミノ酸恒常性調 節に大きく関わると同時に、グルカゴンとインスリンは単なる拮抗的な血糖調 節ホルモンではなく、様々な栄養素に対する代謝調節に扔いて、それぞれが異 なる寄与度で生理的な役割を果たしていると考えられる。 


\section{1-3-1＼cjkstart栄養情報が調節するグルココルチコイド受容体の 転写制御機構の解析}

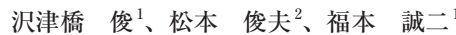

徳島大学 先端酵素学研究所オープンイノベーション領域、 ${ }^{2}$ 徳島大学 藤井 節郎記念医科学センター

グルココルチコイド (GC) は抗炎症薬として有用である一方で、本来の内分 泌ホルモンとしての作用による重䇫な副作用が課題である。これはグルココル チコイド受容体 (GR)を介したGCの作用において感受性や組織特異性を制御す る分子メカニズムが明らかでないことが一因である。我々は GRの転写活性が 細胞内のグルコース代謝状態に応答することを見出し、この栄養状態を反映す る翻訳後修飾としてO-結合型N-アセチルグルコサミン (O-GlcNAc) 修飾を同 定した。そして、O-GlcNAc転移酵素 (OGT) はGRのリガンド依存的な転写活 性を減弱させ、高グルコース条件下に扔いてGRの転写機能を負に調節するこ とを見出した。また、この修飾部位を特異的に認識する抗体を作製したとこ ろ、このO-GlcNAc修飾 GR は高グルコース依存性かつGC 依存性に核内に存 在することを明らかにした。さらに、ゲノム編集によりこの修飾部位のアミノ 酸残基に点変異を導入したマウスを作出したところ、高脂肪食誘導性の肥満に 抵抗性を示す可能性が示唆された。これらの結果は、GC作用はそのホルモン 濃度のみによらず、抹消組織の栄養状態に応じた GR 機能の増強・減弱を翻訳 後修飾によって規定される可能性を示唆している。

\section{1-3-3＼cjkstart髪の毛に含まれるコルチゾール濃度を指標とした 3交代勤務と 2交代勤務のストレス度の比較}

宮内 文久

愛媛労災病院 産婦人科

【目的】髪の毛に含まれるコルチゾール濃度を指標に、3交代勤務と 2 交代勤務 のストレス度を比較検討することで、夜間交替勤務のストレス強度を明らか にし、2交代勤務と 3 交代勤務をめぐる論争に科学的に対応することができる かどうかを検討することとした。【方法】20歳から45歳まで看護師で、規則的 な月経周期を有し、直近の 3 ケ月間に体重の増減や定期的な薬剤の服薬が無い ことを条件に、研究の趣旨を説明し、同意を得たボランテイア女性を対象と して、昼間勤務群 $(\mathrm{N}=10$ 、平均年齢 35.9 歳) と 3 交代勤務群 $(\mathrm{N}=20$ 、31.8歳)、2 交代勤務群 $(\mathrm{N}=10 、 31.3$ 歳) とを比較検討した。髮の毛を約 20 本採取し、LS/ MS-MS法で測定した。なお、本研究は愛媛労災病院の倫理員会の承認（H3089号) を得て、実施した。【結果】(1)体調の自己評価：昼間勤務のみ群では夜 間勤務有り群の 3 交代勤務群と 2 交代勤務群と比較して、有意に高値であった 夜間勤務有り群の 3 交代勤務群と 2 交代勤務群との間では、3交代勤務群が高 值を示した。(2)髪の毛0〜3cm、0〜 6 $\mathrm{cm} 、 0 \sim 9 \mathrm{~cm}$ のルルモン濃度：根元か ら $9 \mathrm{~cm}$ までの髪の毛に含まれるコルチゾール濃度を、0〜 $3 \mathrm{~cm} 、 0 \sim 6 \mathrm{~cm} 、 0 \sim$ $9 \mathrm{~cm}$ で比較検討した。2交代勤務群の濃度は昼間勤務群と比較しても、また 3 交代勤務群に比較しても有意に高值を示した。(3) 髪の毛0～9cmのホルモン濃 度 : 髪の毛の根元から $9 \mathrm{~cm}$ までに含まれるコルチゾール濃度の総量は、2交代 勤務群は尽間勤務群に比較しても、また 3 交代勤務群に比較しても有意に高值 を示した。【結論】2交代勤務群は昼間勤務群とも3交代勤務群とも大きく異な り、コルチゾール濃度は大きく逸脱する結果を得た。つまり、2交代勤務は 3 交代勤務に比較してホルモン環境が大きく影響を受け、生体の恒常性は大きく 乱れていると推測した

\section{1-3-5 中枢性尿崩症の病因と抗 rabphilin-3A抗体}

在原 善英 ${ }^{1} 、$ 桜井 華奈子 ${ }^{1}$ 、新妻 さつき 1 、佐藤 良太 ${ }^{1} 、$ 山田 正三 ${ }^{2}$ 井下 尚子 ${ }^{3}$ 、藤沢 治樹 ${ }^{4}$ 、鈴木 敦詞 ${ }^{4} 、$ 椙村 益久 ${ }^{4}$ ${ }^{1}$ 国立病院機構 仙台医療センター内分泌代謝内科、 ${ }^{2}$ 森山脳神経センター病 院 間脳下垂体センター、 ${ }^{3}$ 東京都健康長寿医療センター 病理診断科、 ${ }^{4}$ 藤田 医科大学 内分泌・代謝内科学

【はじめに】中枢性尿崩症は稀な疾患であり、種々の原因によって引き起こさ れるが、その診断には難渋することが多い。最近、抗 rabphilin-3A (Rph3A) 抗体がリンパ球性漏斗下垂体後葉炎 (LINH) の診断マーカーとして感度、特 異度が高く有用であることが報告された。今回我々は、中枢性尿崩症の病因 と抗Rph3A抗体に関して検討した。【対象】2013年4月から 2019年10月まで に当科で高張食塩水負荷試験を行い診断した中枢性尿崩症を対象にした（術 後発症例は除外)。【方法】画像検査、下垂体前葉ホルモン機能検査、下垂体 生検ほか種々の検查で原疾患を診断した。また抗Rph3A抗体を検討した。【結 果】 中枢性尿崩症 14 例 (男性 8例、女性 6例、年齢23-69歳) あり、内訳は臨 床診断を含めて、リンパ球性下垂体炎9例（LINH 6例、沉下垂体炎3例）、サ ルコイドーシス 2 例、ラトケ囊胞 1 例、頭蓋咽頭腫 1 例、肧腫 1 例であった。抗 Rph3A抗体は 13 例中 9 例で陽性 (LINH 5 例、沉下垂体炎 2 例、サルコイドー シス1例、胚腫 1 例) であった。LINH と診断した1例は結果未着。【まとめ】 中枢性尿崩症の病因としてLINHが多かった。LINHでは結果判明の全例で抗 Rph3A 抗体陽性であった。リンパ球性汎下垂体炎の症例ではMRI画像で下垂 体後葉の炎症が強いと考えられる場合、抗Rph3A抗体陽性となる印象であっ た。サルコイドーシスの陽性例は下垂体生検を行っておらず、肧腫は下垂体生 検で診断したが後葉組織は含まれておらず後葉の所見は得られなかった。【結 語】抗Rph3A抗体検査は診断に有用であると考えられた。

\section{1-3-2＼cjkstart続発性副腎不全患者におけるグルココルチコイド 補充は血中アディポネクチン濃度を上昇させる}

林 令子 ${ }^{1}$ 、玉田 大介 ${ }^{1,2}$ 、奥野 陽亮 ${ }^{1}$ 、村田 雅彦 ${ }^{1} 、$ 向井 康祐 ${ }^{1} 、$ 北村 哲宏 ${ }^{1,2}$ 、福原 淳範 ${ }^{1}$ 、大月 道夫 ${ }^{1}$ 、下村 伊一郎 ${ }^{1}$

${ }^{1}$ 大阪大学大学院医学系研究科 内分泌・代謝内科学、 ${ }^{2}$ 玉田クリニック

【背景】低アディポネクチン血症は心血管疾患リスクを上昇させる。また、副 䁂皮質機能低下症患者では健常人と比較し心血管リスクが高いことが報告さ れているが、血中アディポネクチン濃度を評価した報告はない。今回我々は、 続発性副腎皮質機能低下症患者においてグルココルチコイド(GC)補充の血中 アディポネクチン濃度への影響を検討した。また、その変化に脂肪細胞グル ココルチコイド受容体(GR)が関与する可能性について検討した。【対象と方 法】大阪大学医学部附属病院に抢いて、GC補充治療中である続発性副腎不全 症患者 12 例を対象に、 4 週毎にヒドロコルチゾン $(\mathrm{HC})$ の補充量を $10 \mathrm{mg} /$ 日、 $20 \mathrm{mg} /$ 日、30 $\mathrm{mg} /$ 日と変更する二重盲検交差試験を行い、血中アディポネク チン濃度を比較検討した。また、脂肪細胞特異的GR欠損マウス (AGRKO) と 野生型マウスの血中アディポネクチン濃度を比較した。【結果】続発性副腎不 全症患者ではHC補充量の増加に伴い、血中アディポネクチン濃度は有意に増 加した。また AGRKOでは野生型に比し血中アディポネクチン濃度の有意な 低下を認めた。【結語】副腎皮質機能低下症患者に扔いて GC 補充により血中 アディポネクチン濃度が上昇すること、脂肪細胞 GRが血中アディポネクチン 濃度の維持に関与していることが示唆された。

\section{1-3-4ＳIADHにおける低 Na血症に対するトルバプタン の有効性と安全性（国内第III相試験）}

有馬 寛 ${ }^{1} 、$ 後藤 功一 ${ }^{2} 、$ 本澤 朋久 $^{3}$ 、毛利 誠 ${ }^{3}$ 、渡部 遼 $^{3} 、$ 平野 隆弘 ${ }^{3} 、$ 石川 三衛 ${ }^{4}$ ${ }^{1}$ 名古屋大学 大学院医学研究科 糖尿病内分泌内科学、 ${ }^{2}$ 国立がん研究セン 夕一東病院 呼吸器内科、 ${ }^{3}$ 大塚製薬株式会社、 ${ }^{4}$ 国際医療福祉大学病院 糖尿 病内分泌代謝科

【背景】トルバプタンは、欧米を含む40カ国以上の地域で、SIADHにおける 低 $\mathrm{Na}$ 血症の治療薬として承認され、臨床使用されている。一方、本邦では、 SIADHに抢ける低Na血症治療薬では承認されていない。【目的】SIADH にお ける低 Na血症を有する日本人患者を対象に、トルバプタン $7.5-60 \mathrm{mg} /$ 日を 最大 30 日間投与したときの有効性及び安全性を検討した。【方法】水分摄取制 限を実施しても血清 Na濃度が正常化しないSIADH 患者16例を対象とした非 盲検試験において、トルバプタン $7.5 \mathrm{mg} 、 15 \mathrm{mg} 、 30 \mathrm{mg} 、 60 \mathrm{mg}$ を 1 日 1 回 最大 30 日間経口投与した。投与は、 1 日 $7.5 \mathrm{mg}$ より開始し、効果が不十分で 安全性に問題がない場合は段階的に漸増した。主要評価項目は、最終投与翌 日における血清 $\mathrm{Na}$ 濃度の正常化（血清 $\mathrm{Na}$ 濃度 $135 \mathrm{mEq} / \mathrm{L}$ 以上）割合とした。 【結果】トルバプタンの最終用量は $7.5 \mathrm{mg}$ が 8 例, $15 \mathrm{mg}$ が 6 例, $60 \mathrm{mg}$ が1 例であった。主要評価項目である最終投与日翌日の血清 $\mathrm{Na}$ 濃度の正常化割合 は $81.3 \%$ であった。血清 $\mathrm{Na}$ 濃度の上昇は投与開始後よりみられ，投与期間を 通じて継続した。副作用発現頻度は 16 例中 10 例であり、主な副作用は，口渴 3 例，血中クレアチニン増加 2 例及び体重減少 2 例であった。【結論】日本人 SIADH 患者に対するトルバプタン投与は、速やかで持続的な血清 $\mathrm{Na}$ 濃度の 正常化を示し、概ね安全で忍容性が良好であることが示唆された。

\section{1-3-6 下垂体腺腫に対する手術操作と中枢性尿崩症の発 生についての検討}

永田 雄一、竹内 和人、山本 太樹、水野 晃宏、若林 俊彦 名古屋大学大学院 医学系研究科 脳神経外科

【序論】下垂体腺腫に対する内視鏡下経鼻術(TSS) は確立された治療法である 一方、術後の中枢性尿崩症(DI) は患者のQOLを大きく損ないうる合併症で あり、その発生を最小限にするような手術操作が求められる。【方法】 2017 年 2 月から 2019 年 10 月の対象期間に、名古屋大学病院で下垂体腺腫に対し てTSSを施行した連続59例 (非機能性腺腫33例 (うち下垂体卒中 1 例)、機能 性腺腫26例) を対象とした。患者背景、腫瘍性状、手術手技、術後DI、術後 低Na血症の発生について後方視的調査を行った。【結果】手術手技としては conventional TSS:54例、 extended TSS:5例であり、DI発生率は一過性 DI:9例 (15.3\%)、恒久性 DI:3 例 (5.1\%) であった。術後DI群の平均腫瘍径は $29.1 \mathrm{~mm}$ であ り、non DI 群の $22.0 \mathrm{~mm}$ と比較して大きい傾向を認めた $(\mathrm{p}=0.058)$ 。手術手技と 術後DI発生との関連としては、腺腫の鞍上進展が強く手術で頭蓋内操作を必 要とした症例では有意に DI発生率が上昇したが $(\mathrm{p}=0.021) 、$ 腫瘍の被膜外摘出 はDI発生の有意な危険因子とはならなかった $(\mathrm{p}=0.362)$ 。下垂体卒中例では 術後恒久性DIを後遺した。また一過性DI群ではその他の群と比較して術後低 Na血症の発生率が高かったが $(66.7 \%$ vs $34.0 \%) 、$ 統計学的に有意な差は認めら れなかった $(\mathrm{p}=0.064)$ 【考察・結語】腫瘍が大きく、高度の頭蓋内進展を認め る症例では術後DIの発生率が高まるため、下垂体荠、後葉に対する愛護的な 手術操作が求められる。一方で被膜外摘出は術後DIの危険因子とはならない ため、特に機能性腺腫に対する被膜外摘出は有用な手術手技であると考えられ る。 


\section{1-4-1 日本人乳幼児 (0-6歳) における腹囲・腹囲身長 比基準值の作成と諸外国基準值との比較}

井ノ口 美香子 ${ }^{1,2}$ 、松尾 宣武 ${ }^{2,3,4} 、$ John I Takayama ${ }^{5}$ 、長谷川 奉延 ${ }^{2}$ ${ }^{1}$ 慶應義塾大学 保健管理センター、慶應義塾大学 医学部 小児科、 ${ }^{3}$ 国立成 育医療研究センター、 ${ }^{4}$ 練馬総合病院 医療の質向上研究所、5 カリフォルニ ア大学医学部 小児科

【背景】乳幼児の肥満評価指標は未確立で検討も不十分である。日本人乳幼児 の腹囲(WC)、腹囲身長比 (WC/S) 基準值の報告はない。

【方法】1. 対象は 1978-81 年収集(日本規格協会・通商産業省) の 0.25-6.25歳日 本人小児の全国データ(男4855人・女4 4688 人)。WC (臍の高さで計測)、WC/ $\mathrm{S}$ の基準値をLMS 法で作成。2. 日本人 (J) 基準值と、乳児(0歳)を含む既報の 基準值(オランダ：D、スウェーデン：S、トルコ：T、WCは肋骨弓下と腸 骨稜の中点で計測、基隻值はD,T: LMS 法、S. Box-Cox-power-exponential distribution 法で作成)の各50パーセンタイル值を同一グラフ上で比較。

【結果】1. 日本人基準値について、0.5, 1.0, 2.0, 4.0, 6.0歳の50パーセン夕 イル值(男/女)を示す。腹囲 (cm): 41.4/40.6, 43.1/42.0, 46.2/46.0, 48.6/48.8, 50.9/50.4。腹囲身長比: $0.62 / 0.62,0.58 / 0.57,0.55 / 0.55,0.49 / 0.49,0.45 / 0.45$ 。2. 男 女とも腹囲 : $\mathrm{J}<\mathrm{T}<\mathrm{D}<\mathrm{S}$ 、腹用身長比 : $\mathrm{J} \doteqdot \mathrm{T} \doteqdot \mathrm{D}<\mathrm{S}$ 。

【考察】本基準值は日本人乳幼児の肥満評価(WC、WC/Sの集団での大きさ、 個人の大きさの変化の評価)、また本基準值と同じ1978-81年デー夕(近年より 肥满小児が少ない基準集団)を基にした6-18歳基準值 (Ann Hum Biol 2015, Int J Obes 2016) との連続的評価に打ける一助になると考元る。WC/Sは様々な身 長の人種の国際比較において有用な指標である。スウェーデンのみが大きい WC/Sを示す理由は不明だが、違いの原因として、人種差、腹囲計測位置、研 究年 (セキュラートレンド)、基準值作成法、対象数の少なさ(特に年少乳児)に よるエッジ効果などを考える。

\section{1-4-3３歳健診での盵満予防の取り組み}

市川 剛 ${ }^{12}$ 、有阪 治 ${ }^{1} 、$ 中山 幸量 ${ }^{2} 、$ 長沼 純子 $^{2} 、$ 小山 さとみ 2 吉原 重美 $^{2}$

${ }^{1}$ 那須赤十字病院 小児科、 ${ }^{2}$ 獨協医科大学小児科

【背景】肥満は世界中で社会問題となっている。高度肥满は治療困難である ことから、予防が重要とされるが、予防法は確立していない。一方、早期 adiposity rebound (AR) は、将来の肥満に嗸がることが知られている。我々 は早期ARを臨床応用し、3歳前にBMI上昇した児が将来の肥満のハイリスク 群であることを示してきた。この知見に基づき、栃木県大田原市 $(\mathrm{O}$ 市)では 2013年〜、那須塩原市 $(\mathrm{N}$ 市) では2017年〜 3歳健診で肥满予防事業を多職種 で実施している。【目的】 3 歳健診での肥满予防における有効率や費用, 今後 の課題などを明らかにする。【方法】1) 3歳健診でBMI 16.8 以上 18.5 未满では、 1 歳半健診の時と比較してBMIが 0.5 以上上昇, 2) 3 歳健診でBMIが 18.5 以上の 時は、1歳半健診の時と比較してBMIが上升1)または2)を満たす児をハイリ スク群として介入対象とする。O市：5歳まで医師（４ケ月おき）、栄養師・臨 床心理士・保健師で介入。N市：栄養士・保健師で3ケ月おきに介入。【結果】 O市は 2274 人が健診を受診、内 121 人 $(5.3 \%)$ がハイリスクと認定。継続受診率 は74.5\%、3歳健診と比較し5歳でBMI\%が $89 \%$ の児で平均 $11 \%$ 改善した。N 市は 956 人が受診し、内 74 人がハイリスクと認定。継続受診率は約 $100 \%$ \% り、多くの児で5歳までの間にBMI\%が改善している。両市とも本事業に関し て申請している予算は0 数万円であった【考察】5歳でのBMI\%の改善が 持続するかどうかが焦点の一つであり、現在前方視的に追跡中である。人件費 は、本来の業務との兼務で行政として追加負担がないのも特筆すべき点であ る。【結論】3歳健診での肥満予防は有効率が約 $90 \%$ と高い。また、新規の予 算をつけずに実施できており、費用対効果が高い方法と考えられる。

\section{1-4-5 腎機能正常者におけるFGF23 と内臓脂肪蓄積との 関連にアディポネクチンが介在する}

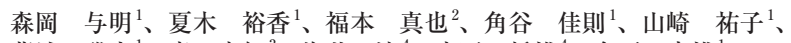

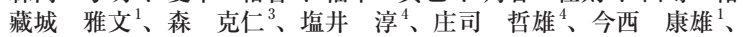

稲葉 雅章 1 、絵本 正憲

${ }^{1}$ 大阪市立大学大学院 医学研究科 代謝内分泌病態内科学、 ${ }^{2}$ 大阪市立大学大 学院 医学研究科 先端予防医療学・MedCity $21 、 3$ 大阪市立大学大学院 医学 研究科 腎臓病態内科学、 ${ }^{4}$ 大阪市立大学大学院 医学研究科 血管病態制御学

【目的】メタボリック症候群(MetS) に执ける血清リンの低值执よび血清FGF23 濃度の高値が示されているが, その機序は明らかでない.今回腎機能正常の 非糖尿病者を対象に血清 FGF 23 濃度と内臓脂肪蓄積との関連性及びそれにア デイポネクチン $(\mathrm{AdN})$ が関与する可能性につき検討した.【方法】当院附属 の健診施設 MedCity21 受診した腎機能正常 (eGFR $\geqq 60)$ の非糖尿病者 198 名

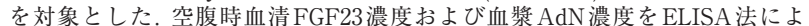
り測定し, 内臓脂肪面積 (VFA)をCTにて測定した.MetSの診断はAHA/ NHLBI (2005)の基準に準拠した。【成續] 全対象（男性52\%）において年齢 52 歳, BMI $22.4 \mathrm{~kg} / \mathrm{m}^{2}$, eGFR $77.8 \mathrm{ml} / \mathrm{min} / 1.73 \mathrm{~m}^{2}$, 血清 $P 3.3 \mathrm{mg} / \mathrm{dL}$, 血清 FGF23 $31.6 \mathrm{pg} / \mathrm{mL}$, 血漿 AdN $8.6 \mu \mathrm{g} / \mathrm{mL}, V F A 65.6 \mathrm{~cm}^{2}$ (いずれも中央値) であった.MetSあり群はなし群に比べて血清P抢よび血槳 AdNは低值を，血 清FGF23は高値の傾向を示した。血清FGF23はVFA と正相関を示し $(\rho=$ $0.258, \mathrm{p}<0.001)$, その関係は年齢, eGFR, 血清Pにて調整後もなお有意であっ た $(\beta=0.293, \mathrm{p}<0.001)$. さらに説明変数に AdNを加えた解析モデルにおいて, FGF23とVFAとの関連は有意でなく, AdNがFGF23との有意な負の関連を 示した $(\beta=-0.228, \mathrm{p}=0.011)$.【結論】腎機能正常者における血清 FGF23濃 度と内臓脂肪蓄積との正の相関関係が示され，その機序としてFGF23と AdN との負の関連性が存在することが示唆された。

\section{1-4-2 小児肥満（学童期以前の発症）から連続した成人 高度肥満患者の特徵〜小览肥満に焦点をあてた J-SMARTサブ解析〜}

田中翔、山口崇、中村祥子、岡 怜奈、渡邊康弘、

河越 尚幸、齋木 厚人、龍野一郎

東邦大学医療センター佐倉病院 糖尿病内分泌代謝センター

【目的】本邦に扔ける肥満外科治療の対象となった高度肥満患者のうち、学 童期以前に肥満を発症し、成人まで持ち越した患者の特徵を明らかにするこ と。【方法】本解析では、難治性高度肥满症の実態を明らかにするための多 施設研究J-SMART (Japanese Survey of Morbid and Treatment-Resistant Obesity) によって収集されたデータベースを用いた。対象はJ-SMARTにエ ントリーされ、スリーブ状胃切除術を施行された高度肥満患者で、小巟肥満群 として、学童期以前に肥满を発症した群と、思春期以降に発症した群とで比較 解析を行った。結果】対象患者は 322 名で、学童期以前に発症した成人高度 肥满患者の身体的な特徴として、BMIが $45.6 \pm 9.35$ vs $42.3 \pm 8.54 \quad \mathrm{P}=0.0008$ と有意に高く、皮下脂肪優位な傾向があり、悪性腫腸が多い傾向があった。生 育環境としては、両親に肥満がある傾向を認めた。また、発達障害羅患率が $9.1 \%$ vs $0.9 \% \mathrm{P}=0.0176$ と有意に高く、全検查IQ と動作性IQが低い傾向を 認めた。【結論】小児期からの肥満で、肥満外科治療の対象となった患者の特 徵として、より BMIが高く、皮下脂肪型の肥满であることが分かった。心理 面の特徵として、発達障害を有する頻度が高いことが明らかとなった。これま で小児肥満に対して、生育環境や発達の問題があることは体感としてはあった が、統計解析上もこれらの問題が明らかになったといえる。

\section{1-4-4 日本人肥満症患者における腹腔鏡下スリーブ状胃 切除術後の減量効果に寄与する因子の解析}

尾関 良則 ${ }^{1} 、$ 相良 早紀 2 、吉田 雄一 ${ }^{1}$ 、岡本 光弘 ${ }^{1}$ 、後藤 孔郎 ${ }^{1} 、$ 正木 孝幸、柴田 洋孝 ${ }^{1}$

${ }^{1}$ 大分大学 医学部 内分泌代謝 - 膠原病 - 腎臟内科学講座、 ${ }^{2}$ 大分大学 医学部

【目的】肥満外科手術は肥满症に扔ける治療法の一つであり、体重減少効果执 よび2型糖尿病の改善効果が全世界で数多く報告されている。肥满外科手術で 著明な体重減少効果が期待できる一方で、術後の体重減少にそしい症例やリバ ウンドを認める症例もみられる。しかし、体重減少効果に寄与する因子はこれ までのところ不明である。本研究では、腹胿鏡下スリーブ状胃切除術後の体重 減少効果に寄与する因子について体組成変化を中心解析することを目的とし た。【万法】2013年11月から 2017年7月までの間に大分大学医学部付属病院に て腹脭鏡下スリーブ状胃切除術が施行された肥满症患者のうち手術前、手術 2 年後に体組成評価を実施できた 22 名を対象とした。午前中に空腹で採血・血 圧測定・体重測定を実施し、体組成に関しては電気インピーダンス法である In-Body770を用いて分析した。手術 2 年後に扔ける減量効果良好群 (全体重減 少卒TWL $\% \geqq 25 \%) 、$ 減量効果不良群 $(T W L \%<25 \%)$ の 2 群に分け体組成変化を 経時的に評洒した。【結果】術後 2 年の減量不良に寄与する因子は単変量口ジ スティック回帰解析において術後 1 年での体脂肪率、全筋肉率、全筋肉量、骨 格筋量の変化量㧍よび術後半年での全筋肉量の変化量であった。多変量ロジス ティック回帰分析に执いては術後 1 年での体脂肪率、全筋肉率の変化量抽よび 術後半年での全筋肉量の変化量が寄与する因子として残る結果であった。結 語】 術後 1 年に扔ける体組成評価で体脂肪率が下がり、筋肉率が保たれるほど 2 年の減量効果は良い可能性があると考えられた。術後に体組成評価をするこ とで、その後の減量効果を予測できる可能性が示唆された。

\section{1-4-6 ヒト白色脂肪細胞からのアディポネフチンおよび レプチン分泌に及ぼすアンギオテンシン受容体阻 害薬 (ARBs) の効果}

中辻 俊哉 ${ }^{1}$ 服部 尚樹 ${ }^{1} 、$ 西田 夏華 ${ }^{1}$ 、松田 孟子 ${ }^{1}$ 、千原 一久 1 、 島津 章 $^{2}$

立命館大学 薬学部、 ${ }^{2}$ 草津総合病院先進医療センター

【目的】アンギオテンシン受容体拮抗薬(ARBs)の一部はPPAR $\gamma$ 部分アゴニス 卜としてアディポネクチン分泌を促進することが知られている今回、比 白色脂肪細胞からのアディポネクチンとレプチン分泌に対するARBsの効果を 検討した。【方法】ヒト白色脂肪細胞にピオグリタゾンとARBs（テルミサル タシ、イルベサルタン、アジルサルタン、カンデサルタン、ロサルタン、オ ルメサルタン、バルサルタン）を各 $1 \mu \mathrm{M}$ で負荷し、培養液中のアディポネク チン、レプチン濃度を醇素免疫測定法で、mRNA発現を定量的PCR 法で測定

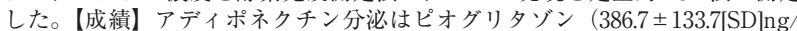

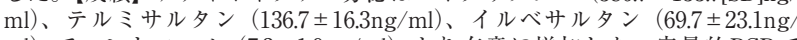
$\mathrm{ml})$ でコントロール $(7.3 \pm 1.9 \mathrm{ng} / \mathrm{ml})$ より有意に増加した。定量的PCRで アディポネクチン mRNA発現量はピオグリタゾン、テルミサルタン、イルベ サルタンで5.1倍、3.8倍、1.5倍にそれぞれ増加した。レプチン分泌はピオグ リタゾン $(27.7 \pm 5.0 \mathrm{ng} / \mathrm{ml})$ 、テルミサルタン $(38.7 \pm 4.2 \mathrm{ng} / \mathrm{ml})$ 、イルベサル タン $(62.0 \pm 7.2 \mathrm{ng} / \mathrm{ml})$ でコントロール $(82.5 \pm 3.8 \mathrm{ng} / \mathrm{ml})$ より有意に低下し た。定量的PCRでレプチン mRNA発現量は 0.5 倍、0.7倍、0.9倍に低下した。 PPAR $\gamma$ 阻害薬の GW $9662(5 \mu \mathrm{M})$ は、ピオグリタゾンとARBsによるアデイポ ネクチン分泌促進作用に拮抗したが、レプチン分泌抑制作用には捛抗しなかっ た。【結論】テルミサルタンとイルベサルタンによるアデイポネクチン分泌促 進作用はPPAR $\gamma$ を介するが、レプチン分泌抑制作用は別の機序によることが 示唆された。 


\section{1-4-7２番染色体 p 25.3部欠失が原因と考えられた遺伝 性肥満の一例}

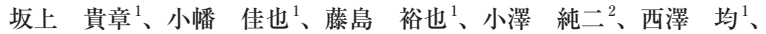
松岡 孝昭、岩橋 博胃 ${ }^{2}$ 、前田 法一 ${ }^{3}$, 大月 道夫 ${ }^{1}$ 、山本 俊至 ${ }^{4}$ 、 下村 伊一郎

${ }^{1}$ 大阪大学大学院医学系研究科 内分泌代謝内科学、 ${ }^{2}$ 大阪大学医学系研究科 糖尿病病態医療学寄附講座、 3 大阪大学医学系研究科 代謝血管学寄附講座、 ${ }^{4}$ 東京女子医科大学 ゲノム診療科

【症例】31歳女性【現病歴】体重 $3600 \mathrm{~g}$ の正期産で出生し、周産期、新生児期 に異常は認めなかった。哺乳は良好で、生後1か月で体重はすでに+2SD以上 だった。運動発達は問題なかったが、言語発達漣滞を認めた。体重は過食の ため乳児期以隆增加を続け、20歳時で100kg（BMI40.5）程度まで増加。31歳 時、体重は $122 \mathrm{~kg}$ まで增加し、 HbAlc8.7\% と糖尿病も指摘され当科紹介受診。 減量および血糖コントロール目的に当科入院した。【経過】身長 $157.2 \mathrm{~cm}$ 、体 重122.3kg、BMI49.5 と高度肥满を認めた。身体所見で左間欠性外斜視、両側 握力低下、両側白内障を認め、IQ54 と軽度知的障害を認めた。高度肥满や知 的障害の家族暦は認めなか力た。糖尿病に関しては入院後、食事療法と経口血 糖降下薬で加療を行った。病歴より2次性肥満の可能性を考え精查を施行し、 内分泌学的異常は認めずPrader-Willi症候群も否定された。染色体解析として G-band 解析とFISH 解析を施行し2番染色体短腕遠位部欠損が疑われた。更な る詳細な検查としてマイクロアレイCGHを施行し、2番染色体 $\mathrm{p} 25.3(2 \mathrm{p} 25.3)$ 部 分欠失と診断した。【考察】 $2 \mathrm{p} 25.3$ 領域の欠失により、肥満と知的障害を中心 とした症候群を呈することが知られており、現在まで34例の報告があるが本 邦からの報告はない。神経の発生に関与するMYT1L遺伝子が責任遺伝子と考 えられているが、詳細な病因は不明である。本症例では、他の家族の遺伝子検 查は施行できなかったが幼少期からの肥满や知的障害を認めず de novo と考元 られた。

\section{1-4-9 Beige脂肪細胞におけるNeuromedin B (NMB) の生理機能解析}

比嘉 涼子 ${ }^{1}$ 、森崎 郁子 ${ }^{2}$ 、鹿野 健史朗 ${ }^{1}$ 、花田 俊勝 ${ }^{2}$ 花田 礼子 ${ }^{1}$ ${ }^{1}$ 大分大学 医学部 神経生理学講座、 ${ }^{2}$ 大分大学 医学部 細胞生物学講座

熱産生機構を有する脂肪細胞である beige脂肪細胞は、全身のエネルギー代謝 量を増加させ、肥満やインスリン抵抗性などの代謝異常を改善する作用を持 つことが報告されている。beige脂肪細胞を活性化することは肥満症の改善に 役立つと考えられるが、熱産生細胞の分化・活性化の詳細な分子機構につい ては未だ不明な点が多い。我々は、beige脂肪細胞の分化・活性化制御因子を 同定するため、マウス鼠蹊部皮下脂肪組織より白色脂肪前駆細胞株と beige 脂 肪前駆細胞株を独自に樹立した。この二つの脂肪細胞の特徵を検討したとこ ろ、 beige 脂肪細胞は白色脂肪細胞に比べ成熟脂肪細胞へ分化しにくいことが 明らかとなった。そこで、樹立したbeige脂肪細胞を用いて成熟脂肪細胞へ の分化能を指標とし、shRNA ライブラリースクリーニングを行った。その結 果、 beige脂肪細胞の分化を抑制する候補遺伝子として生理活性ペプチドであ る Neuromedin B（NMB）が同定された。NMBは全身のエネルギー代謝調節 機構に関与することは知られているが、NMB と beige脂肪細胞との関連につ いては不明である。そこで我々は、beige脂肪細胞に扔けるNMBの機能を検 討するため、CRISPR-Cas9 システムを用いてNMB 遺伝子欠損マウスを樹立し た。NMB遺伝子久損マウスと野生型マウスを用いて、通常食掞よび高脂肪食 摂餌時のエネルギー代謝調節機構に関する一連の解析を行ったので報告する。

\section{1-4-11 SGLT2 阻害薬の肝糖新生応答に対する作用の検討}

橋内 咲実 ${ }^{1}$ 、稲葉 有香 ${ }^{2}$ 、渡邊 一史 ${ }^{2}$ 、小川 千尋 ${ }^{1}$ 、井上 啓 ${ }^{1,2}$ ${ }^{1}$ 金沢大学 医薬保健学総合研究科 代謝生理学分野、 ${ }^{2}$ 金沢大学 新学術創成研 究機構 栄養・代謝研究ユニット

SGLT2 阻害薬（SGLT2i）は、腎糖排泄を促進する一方で、肝糖新生を増強 する。肥満・インスリン抵抗性では、肝糖新生の増加が高血糖の誘因とな る。しかし、肥満病態で立進した肝糖新生に対して、SGLT2iが与える作用に ついては、十分な解明がなされていない。今回、健常及び肥満病態に拈ける、 SGLT2iの肝糖新生に対する作用を検討した。肝糖新生を評価する為、肝糖 新生酵素遺伝子である G6pcのプロモーター制御下に、分泌型ルシフェラーゼ （GLuc）を導入した肝 G6pcレポーターマウスを作成した。当該レポーターマ ウスでは、血中GLuc活性により、肝G6pc 発現を評価することができる。実 際、血中GLuc 活性は、肥満誘導により健常時の約 10 倍に増加する。そこで、 健常及び肥満レポーターマウスに対し、SGLT2iの単回及び長期投与（4週間） を行った。SGLT2i単回投与は、健常マウスで、血糖值・インスリン值を低下 させ、GLuc活性を上昇させた。肥満マウスでは、血糖值・インスリン值を低 下させたが、GLuc活性に変化を与えなかった。SGLT2i長期投与は、健常マウ スで、血糖值・インスリン值を低下させ、GLuc活性の一過性増加を惹起した。 一方、肥満マウスでは、血糖值・インスリン值を低下させ、肥満により増強し たGLuc 活性を低下させた。SGLT2i長期投与は、血漿インスリン值を低下さ せるが、肝Aktリン酸化は増強させた。本研究に执いて、SGLT2iの肝糖新生 応答に対する作用はインスリン抵抗性の有無で異なること、さらに、SGLT2i 長期投与は、肥満に伴うインスリン抵抗性を改善させ、肝糖新生を抑制するこ とを見出した。
01-4-8 Repressor element 1 silencing transcription factor (REST) の脂肪細胞ミトコンドリア生成に おける役割

梶田 和男、浅野 元尋、森田 浩之 岐阜大学大学院医学系研究科 総合病態内科学

【目的】我々は脂肪細胞に多くの神経細胞遺伝子の発現を見出したが、これら に機能的関連はなく、意義は不明であった。REST は幹細胞あるいは神経以外 の分化細胞に発現し、これらが神経細胞に分化するのを止めている。今回我々 はRESTを脂肪細胞特異的に欠失させたマウス (REST-KO)を作出し、神経絸 胞遺伝子の過剩発現の影響をみた。【方法】REST-floxed Adipoq-Cre と交 配してREST-KOを作出し、その表現型を傍精巣脂肪(E)、鼠経脂肪(I)、褐色 脂肪(B)でAdipoq-Creを対照として検討した。【成績】REST-KOは対照に比 脂肪(B)で Adipoq-Creを対照として検討した。【成績】REST-KO は対照に比
ベ、多くの神経細胞遺伝子の登現が増加していたが、脂肪細胞特異的遺伝子の べ、多くの神経細胞遺伝子の発現が増加していたが、脂肪細胞特異的遺伝子の しないと考えられた。一方REST-KOは対照に比心゙、脂肪重量が増加していた が、摂食量には差がなく、酸素消費量が減少ていた。MicroarrayによるEと B

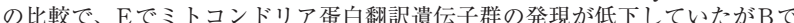

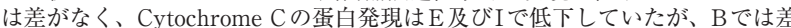
がなかった。一方 $\beta 3$-adrenergic agonistによるbrowningはE、I共、対照と 差がなかった。B、beige cellのミトコンドリア生成はPGC1 $a$ により制御され ているが、白色脂肪脂肪のミトコンドリアは別の機序により生成されていと考 えられており、RESTは後者に関与していることが示唆された。結論】REST は白色脂肪細胞のミトコンドリア生成を正に制御していると考えられた。

\section{1-4-10 新規マイオカインの同定と運動による糖・脂質・ エネルギー代謝調節メカニズムの解明}

岩部 真人、岩部 美紀、小田原 紗羅、門脇 友莉、山内 敏正、 門脇 孝 東京大学 医学部 糖尿病・代謝内科

【目的】肥満や 2 型糖尿病に対して、運動が有効な予防法・治療法であること は広く知られているが、詳細なメカニズムについては十分に解明されていな い。今回、運動によってCaMKK シグナル依存的に発現が増加する新規マイオ カイン Exercise-induced protein derived from muscle 1 (EXPM1) を同定し、 EXPM1 介代し糖・脂質・エネルギー代謝調節メカニズムの解明を行った。 【方法・結果】EXPM1 欠損マウスを作製・解析し、EXPM1 欠損マウスでは、 耐糖能障害、インスリン抵抗性、脂質代謝異常が認められた。さらに野生型、 ウスは、有酸素運動により体重が減少したが、EXPM1 欠損マウスは運動によ り体重が減少しなかった。また、野生型マウスでは、運動により酸素消費量が 増加、体温が上昇したが、EXPM1 欠損マウスではいずれも起こらなかった。 そのメカニズムについて解析したところ、野生型マウスの白色脂肪組織では運 動により、ミトコンドリア関連遺伝子、脂肪酸燃焼の関連遺伝子、ベージュ化 のマーカー遺伝子の発現が上昇したが、EXPM1 欠損マウスでは変化がなかっ た。また、糖・脂質代謝についても検討したところ、野生型マウスにおける運 動による耐糖能障害、インスリン抵抗性、脂質代謝の改善作用は、EXPM1 久 損マウスでは認められなかった。【結語】 EXPM1が運動による白色脂肪組織 のベージュ化に関与し、糖・脂質・エネルギー代謝を調節していることが分 かった。EXPM1によるベージュ化のメカニズムを明らかにすることは、運動 による代謝調節メカニズムを解明するだけでなく、肥満や 2 型糖尿病に対する 予防法・治療法の道を切り開く可能性があると考えられた。

\section{1-4-12 新規脳内因子NPGL/NPGM遺伝子欠損マウスを 用いた生理機能解析}

鹿野 健史朗 ${ }^{1}$ 、森崎 郁子 ${ }^{2}$ 、比嘉 涼子 ${ }^{1}$ 、花田 俊勝 ${ }^{2}$ 、花田 礼子 $^{1}$ ${ }^{1}$ 大分大学 医学部 神経生理学講座、 ${ }^{2}$ 大分大学 医学部 細胞生物学講座

Neurosecretory protein GL (NPGL) 及びNeurosecretory protein GM (NPGM) は鳥類やげっ歯類の視床下部から発見された分泌性小タンパク質で ある。げっ歯類において NPGL及びNPGMは視床下部の摂食中枢に局在して いることや遺伝子発現解析により NPGL/NPGMがエネルギーホメオスタシス 調節に関与することが示唆されている。先行研究では、遺伝子過剩発現実験や 投与実験により、NPGL/NPGMが摂食充進作用や脂肪組織に抢ける de novo 脂肪合成の忘進による脂肪量増加作用を有することを明らかにしてきた。この ように、これまではgain of functionの解析により NPGL/NPGMの生理作用を 追究してきたが、その生理機能や作用機序に関しては未だ不明な点が多い。本 研究では、CRISPR/Cas9システムを用いてNPGL及びNPGM 遺伝子久損マウ スを作製し、生理機能解析を行うことを目的とした。受精卵エレクトロポレー ション法を用いて、Cas9タンパク質や gRNAを受精卵に導入し、ゲノム編集 を行った。その結果、成熟 NPGLあるいはNPGMタンパク質をコードする領 域内の約 400 塩基が欠損したマウスの作出に成功した。さらに、高脂肪食給慨 下に抢いて、NPGL 遺伝子久損マウスは体重増加量の減少や脂肪組織拉よび肝 臟における脂肪量の低下が認められた。以上より、NPGL 遺伝子欠損マウスは 食餌誘導性肥満を抑制することが明らかになった。 


\section{1-4-13＼cjkstart副腎性サブフリニカルクッシング症候群の手術適 応：顕性クッシング症候群 (OCS) との比較研究}

浅井 志高 ${ }^{12.6}$ 、方波見 卓行 ${ }^{2.6} 、$ 田辺 晶代 ${ }^{3.6}$ 、成瀬 光栄 ${ }^{4.6} 、$ 伊澤 正一郎 ${ }^{6}$ 、田中 逸

${ }^{1}$ 川崎市立多摩病院 代謝・内分泌内科、 ${ }^{2}$ 聖マリアンナ医科大学横浜市西部 病院、影国立国際医療研究センター病院、 ${ }^{4}$ 京都医療センター、聖マリアン ナ医科大学、 ${ }^{6} \mathrm{ACPA}-\mathrm{J}$ 研究班

【目的・方法】確立された副腎性不顕性クッシング症候群(SCS)の手術適応 はないが、(DST) 後の血中コルチゾール (F) $\geq 5 \mu \mathrm{g} / \mathrm{dl}$ の場合は推奨との見 解が多い。そこでACPA-J参加8施設で診断され、要件を満たすSCS $(93$ 例）と副腎性顕性 CS(OCS、102例)の臨床像、併存症、治療を比較。【結果】 OCSはSCSに比べ、若年 $(470 \pm 1.3$ vs $57.0 \pm 12$ 歲、平均土標準誤差)、女性 例が多く(男/女 $=10 / 91$ vs $24 / 69$ )、血中 $\mathrm{K}$ は低值 $(3.8 \pm 0.1$ vs $4.0 \pm 0.4 \mathrm{mEq} /$ 1). $\mathrm{LDL}-\mathrm{C}(132.6 \pm 4.2 \mathrm{vs} 115,3 \pm 3.9 \mathrm{mg} / \mathrm{dl})$ と TG(142.9 $\pm 9.5 \mathrm{vs} 113.3 \pm 5.6 \mathrm{mg} /$ dl) は高値。OCS群の $1 \mathrm{mgDST}$ 後 $\mathrm{F}(18.5 \pm 0.6 \mathrm{vs} 9.4 \pm 0.4 \mu \mathrm{g} / \mathrm{dl})$ 、早朝・夜間 の $\mathrm{F}(17.7 \pm 0.6$ vs $12.1 \pm 0.4 、 17.6 \pm 0.6$ vs $9.4 \pm 0.4 \mu \mathrm{g} / \mathrm{dl}) 、 \mathrm{UFC}(280.4 \pm 34.3$ vs $56.1 \pm 5.6 \mu \mathrm{g} /$ 日 $)$ は高値で、ACTHの基礎值 $(2.3 \pm 0.4$ vs $8.7 \pm 1.0 \mathrm{pg} / \mathrm{ml})$ と CRH 目荷後媔值 $(34 \pm 0.9$ vs $26.8 \pm 47$ 弤值 $(p<0.01)$ OCSでの骨折 (odds 比：OR $4.2 、 95 \%$ CI $1.7 \sim 10.3$ ) 、骨粗㣰症(OR $2.5 、 95 \%$ CI $1.3 \sim 4.8$ ) の有病率は高值 だったが、心不全、複合心血管合併症、重症感染、高血圧、耐糖能障害、脂質 異常症に有意差なし。手術はOCSの $95 \%$ 、SCSの $61 \%$ で施行、術後グルココ ルチコイド (GC) 補償はOSCで高率 99 vs $90 \%)$ かつ長期 $(24.6 \pm 2.6$ vs $13.4 \pm$ 3.4 ケ月）。結語】 F 過剩産生はOCSで高度だが、骨合併症を除く合併疾患の 有病率に差はなく、皘極的に手術を推奖すべきと考えられる。(本研究は国立 国際医療研究センター国際医療研究開発費「30指 $1008 」$ 支援を受けた。)

\section{1-4-15１8F-FDG PET陽性を示すコルチゾール産生性副 腎Black adenomaの特徵}

石渡 一樹 ${ }^{1} 、$ 鈴木 佐和子 ${ }^{1,2}$ 、類家 裕太郎 ${ }^{1,2}$ 、内藤 久美子 ${ }^{1,2} 、$ 石田 晶子 ${ }^{1.2}$ 藤本 真德 ${ }^{1,2}$ 、出口 ハンナ ${ }^{1.2}$ 、田村 愛 $^{1.2} 、$ 志賀 明菜 ${ }^{1,2}$ 、小出 尚史 ${ }^{1,2}$ 、横手 幸太郎 1,2

千葉大学 医学部附属病院 糖尿病代謝内分泌内科、 ${ }^{2}$ 千葉大学 大学院医学研 究院 内分泌代謝・血液・老年内科学

【目的】画像の進歩により18F-fluorodeoxygulucose（18F-FDG）PET 陽性副 腎腫瘍に遭遇する機会が增え、副腎癌や転移性副腎癌との鑑別に苦慮すること をしばしば経験する。中には、経過観察中増大を認めず臨床的に良性腺腫と想 定される症例も存在するため、18F-FDG PET陽性を示す良性副腎腫瘍の特徵 につき検討を行った。【方法】対象は2013年から2018年の間に18F-FDG PET を施行し千葉大学医学部附属病院 糖尿病代謝内分泌内科で入院精查を行った コルチゾール産生副腎腫瘍 35例（腺腫、両側副袩大結節性過形成、副腎癌）。 35例の中で18F-FDG PETに拈けるSUVmaxが高い群の腫癔形態およびコル チゾール産生能の特徽、更にグルコース代謝・脂質代謝・TCA イクル関連 遺伝子発現の特徵を検討した。【結果・考察】副腎皮質癌はすべてSUVmax 5 以上であったが、良性副腎腫場でもSUVmax 5 以上を示す症例が $31 \%$ 存在し た。驚いたことにSUVmaxが高い程高いコルチゾール自律産生能を有し、脂 質成分の少ないBlack adenomaの形態を示すことが判明した。更にSUVmax 值と、良性コルチゾール産生腪塬摘出副堅検体におけるトランスポーター GLUT1・GLUT3遺伝子およびIDH1遺伝子との間に有意な正の相関を認めた。 このことから診断・治療決定の際にコルチゾール产生性副腎腺腫のうち特に Black adenomaはPET 陽性を示す可能性があることを念頭に置く必要がある と考えられた。

\section{1-4-17 原発性アルドステロン症における機能確認検査と 24 時間血圧および臟器障害との関連}

吉田 雄一 ${ }^{1} 、$ 吉村 咲紀 2 、木下 みずき 1 尾関 良則 ${ }^{1} 、$ 岡本 光弘 ${ }^{1}$ 後藤 孔郎 ${ }^{1} 、$ 正木 孝幸 ${ }^{1}$ 、柴田 洋孝 ${ }^{1}$ ${ }^{1}$ 大分大学 医学部 内分泌代謝 - 膠原病・腎臟内科学講座、 ${ }^{2}$ 大分大学 医学部 医学科

【目的】夜間高血圧は脳心血管イベントが増加すると言われており、24時間血 圧の評価は重要である。原発性アルドステロン症（PA）は血圧を同程度にコ ントロールした本態性高血压と比べて脳心血管イベントが多いが、その機能碓 認検查の結果と、24時間血圧や心血管障害との関連の報告はない。今回、24 時間血圧測定(ABPM) とPAの機能確認検查の結果を解析し、機能確認検查に よるPA重症度予測が可能か検討した

【方法】2018年1月から 2019年10月までに大分大学医学部附属病院内分泌糖 尿病内科に入院し、ABPMを実施され、機能確認検查（生理食塩水負荷試験 (SIT)、カプトプリル試験(CCT)、経口食塩負荷試験(OSLT)）の結果、PA と診 断された80例とPAが除外診断された33例 (非PA) を用いた。

【結果】 PAと非PAの血圧を换討したところ、随時血圧に差はなく、ABPMで は収縮期血圧 (24h SBP) はそれれぞれ $123.4 \pm 1.6 、 113.2 \pm 2.6 \mathrm{mmHg}$ 、拡張期血圧 (24h DBP) はそれぞれ $81.9 \pm 1.3 、 75.8 \pm 1.5$ であり PAの方が有意に高かった(と もに $<0.01$ ) 各機能確認梌查と $24 \mathrm{~h}$ SBPを比較したところ、SITとCCTでは 判定結果と 24h SBPに差を認めず、OSLTでは陽性例と陰性例の $24 \mathrm{~h}$ SBPが それぞれ $129.4 \pm 3.1 、 119.9 \pm 3.0 \mathrm{mmHg}$ であり、陽性例は有意に24h SBPが高 值だった $(\mathrm{p}=0.036)$ 。さらにOSLTの陽性例と陰性例を比較したところ、2 群 の HbA1cに差はなく、尿中アルブミン (U-Alb) 值はそれぞれ $51.6 \pm 22.5 、 3.0 \pm$ $0.3 \mathrm{mg} /$ 日であり、陽性例は有意にU-Albが増加していた $(\mathrm{p}=0.043)$

【考察】機能確認検查の中で経口食塩負荷試験の結果は心血管合併症やPA重 症度の予測因子となり得ることが初めて明らかとなった。

\section{1-4-14＼cjkstart副腎性フッシング症候群/サブフリニカルクッシン グ症候群における心血管合併症の実態}

伊澤 正一郎 ${ }^{1,6}$ 、田辺 晶代 ${ }^{2,6}$ 、成瀬 光栄 ${ }^{3,6}$ 、方波見 卓行 ${ }^{4,6}$ 吉本 貴宣 ${ }^{5,6} 、$ 大月 道夫 ${ }^{6} 、$ 曽根 正勝 ${ }^{6} 、$ 武田 仁勇 ${ }^{6} 、$ 岡村 真太郎 ${ }^{6}$ 、一城 貴政 ${ }^{6}$

鳥取大学医学部 病態情報内科学分野、 ${ }^{2}$ 国立国際医療研究センター病院 糖 尿病内分泌代謝科、 ${ }^{3}$ 京都医療センター・武田総合病院内分泌センター、 4 聖 マリアンナ医科大学 横浜市西部病院、 ${ }^{5}$ 東京都立広尾病院、 ${ }^{6} \mathrm{JRAS} / \mathrm{ACPA}-\mathrm{J}$ 研究班

【背景】副腎性クッシング症候群 (CS) と潜在性CS (SCS) では合併症について診 断後の管理が推奨されるが、心血管合併症と内分泌学的重症度の関連を示す報告

は少ない。 【。方法】2006年1月～2016年12月にACPA-J研究に参加の 8 施設にてCS/SCS と 診断した患者のカルテ情報を登録用WEBによる電子的臨床検查情報収集にて抽 出、初回診断時の所見を解析した

【結果】286例 (平均年齢55 515 歳、男女比 72:214) を解析した。CSと診断した 113 例（平均年齢 $48 \pm 14$ 歳、男女比 12:101）とSCS と診断した 173 例 (平均年齢 $59 \pm 14$ 歳、男女比 60:113) を比較すると、CSは有意に女性に多く若年発症であっ た $(\mathrm{p}<0.001)$ 。心血管合併症はCSの $18 / 113$ 例 $(15.9 \%)$ 、SCSの $30 / 171$ 例 $(17.5 \%)$
で認められたが有意差は認めなかった。しかし心不全はCSの7/113例 $(6.1 \%) 、$ で認められたが有意差は認めなかった。しかし心不全はCSの7/113例 (6.1\%)、 疾患、脳血管障害、腎機能障害の頻度も解析したが、有意差は認めなかった。 【考察】CS/SCSでは心血管合併症の合併頻度が高い点は既知だが、本検討て は内分泌学的重症度と心不全の関連性が示唆された。今後の症例蓄積、外科 治療によるイベント抑制効果等の検証が必要である。(研究資金：国立国際 医療研究センター国際医療研究開発費「24指1402」・「30指 1008」、AMED JP18ek0109352)

\section{1-4-16 原発性アルドステロン症における腎障害は心血管 イベントと異なり血中アルドステロン值と直接相 関する}

川島 彰透 ${ }^{1} 、$ 曽根 正勝 ${ }^{1} 、$ 稲垣 暢也 ${ }^{1} 、$ 武田 仁勇 ${ }^{2} 、$ 伊藤 裕 $^{3} 、$ 栗原 勲 ${ }^{3} 、$ 一城 貴政 ${ }^{4} 、$ 方波見 卓行 ${ }^{5}$ 、和田 典男 ${ }^{6}$ 、小川 佳宏 ${ }^{7}$ 、 宮内 省蔵、鈴木 知子 9 、成瀬 光栄 ${ }^{10}$ 、 JPAS and JRAS Study Group ${ }^{10}$

京都大学、 ${ }^{2}$ 金沢大学、 ${ }^{3}$ 慶應義塾大学、 ${ }^{4}$ 済生会横浜市東部病院、 ${ }^{5}$ 聖マリア ンナ医科大学、 ${ }^{6}$ 市立札幌病院、 $九$ 州大学、 ${ }^{8}$ 愛媛県立中央病院、9 国際医療 福祉大学、 ${ }^{10}$ 武田総合病院

【目的】原発性アルドステロン症 (PA)はしばしば腎障害を合併する．PAにおける 腎障害の有病率と，そのオッズ比を増加させる因子を解析した。

【方法】日本におけるPA患者の多施設共同研究 (JPAS)のデー夕ベース、および 本態性高血圧症 (EHT)患者のデータを後ろ向きに解析した．年齢，性別，収縮期 血圧，罹病期間をマッチコせたEHTの患者とPA患者のchronic kidney disease (CKD) 蛋白尿推算糸球体瀘過量 (eGFR) 低下 0 有病率を比較 れらの婜障害のオッズ比を増加させる因子を多変量ロジスティック回帰分析で解析

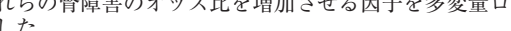
【成績】 2366 人のPA患者を解析した。腎障害の有病率は, CKD 19.7\%, 蛋白尿 10.3\%, eGFR低下 $11.6 \%$ であった。背景因子をマッチさせたEHT患者との比較て は，PA患者において蛋白尿が有意に多かったが (16.8\% vs 4.4\%, $p=0.002), C K D$, eGFR低下の割合は有意差を認めなかった $(28.9 \%$ vs $19.1 \%, p=0.079,17.2 \%$ vs $15.0 \%, p=0.628)$. 多変量ロジスティック回帰分析では, 既存のリスク因子で調整 しても血漿アルドステロン濃度 (PAC) は, CKD, 蛋白尿, eGFR低下のオッズ比を 増加させる因子であった。

【結論】PA患者における腎障害はPACと密接に相関していた。我々は最近，同じ データベースを用いた研究で, PA患者に打ける心血管合併症はPAC自体との直線 的な相関を証めないことを報告しており今忠者の結果とは対昭的である, PA患者 に扔ける腎障害は大血管合併症と異なる機序が想定され，興味深い結果であった。

\section{1-4-18 原発性アルドステロン症患者における糖尿病合併 は脳心血管イベントと顕性蛋白尿リスクを上昇さ せる}

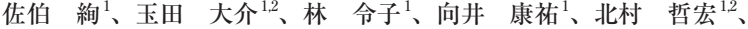
大月道夫 ${ }^{1}$ 、下村 伊一郎 ${ }^{1}$ 、成瀬 光栄 ${ }^{3} 、 J P A S / J R A S$ 研究班 ${ }^{1,3}$ ${ }^{1}$ 大阪大学大学院医学系研究科 内分泌・代謝内科学、 ${ }^{2}$ 玉田クリニック、 ${ }^{3}$ 京 都医療センター・医仁会 武田総合病院

【背景】原発性アルドステロン症(PA)において糖尿病(DM)の合併は 82-23.0\% であり、一般人口に比べ高率である。PA と DMは両者ともに脳心血管(CCV) イベントや腎障害のリスクとなるが、PAに拉いてDM合併がそれらのリスク 因子となるかは不明である。【方法】JPAS/JRAS登録PA患者のうち、コルチ ゾール自律分泌を認めないPA 2524 例を対象とし、DM合併PA群(DM群) と $\mathrm{DM}$ 非合併 $\mathrm{PA}$ 群 ( $\mathrm{nDM}$ 群)の臨床的背景、CCV イベント、腎障害を比較検討 した。【結果】 DM群は389例(15.4\%)であり、nDM群(2135例)に比し、有意に 男性が多く、高齢であり、BMIが高く、高血圧罹病期間が長く、降圧薬数が 多く、脂質異常症の頻度が高く、喫煙の頻度が高く、CCV イベント $(13.9 \%$ vs. $6.0 \%)$ 抢よび顕性蛋白尿 (24.8\% vs. 9.6\%)の頻度が高かった。また、CCVイベン 卜、顕性蛋白尿を従属変数とした多変量解析に扔いて、DMはCCVイベント (OR 159，95\% CI. 1.05-241) 顕性蛋白尿(OR 225,95\% CI. 1.59-3.16)の独立L たリスク因子であった。結論】本研究により PA患者においても DMの合併 は、CCVイベントや顕性蛋白尿の独立したリスク因子となることが明らかと なった。PA治療はCCV イベント発症や腎症の進行を防ぐのみならず、耐糖能 障害の改善、また高血糖状態自体が腎臓におけるミネラロコルチコイド受容 体(MR)遺伝子発現上昇やMR蛋白の安定化を招くことが報告されている。以 上より、PAばかりでなく DMへの治療介入により、CCVイベントや顕性蛋 白尿リスクをさらに軽減できる可能性が示された。(AMED-JP17ek0109122) JP19ek0109352) 
01-4-19 原発性アルドステロン症における副腎静脈サンプ リングの診断効率に関する検討（国際共同研究 AVSTAT study)

成瀬 光栄 1.2 、大野 洋一 ${ }^{3}$ 、兽根 正勝 ${ }^{3} 、$ 方波見 卓行 ${ }^{4} 、$

一城 貴政 ${ }^{5}$ 、角谷 美樹、立木 美香 2 、JRAS研究班 ${ }^{2}$

1 医仁会武田総合病院 内分泌センター、京都医療センター 臨床研究セン

夕ー、 3 京都大学 糖尿病・内分泌・栄養内科学、 ${ }^{4}$ 聖マリアンナ医大横浜市 西部病院、 ${ }^{5}$ 済生会横浜市東部病院 糖尿病・内分泌センター、 ${ }^{6}$ 兵庫医大 糖 尿病・内分泌・代謝科

PAの片側性診断にAVSが推奖されるが、診断効率の詳細は不明。【目的】PA でのAVS害施、副䁂摘出術（ADX）選択における活用の実態を解明。【方 法】 ENS@T 10施設、日本 6施設が参加。2006年から2018年の4818例を 対象。患者数、AVS実施数、病型、ADX率、片側PAの非 ADXの理由を解 析。【成績】 患者数、AVS 実施数は過去 10 年間で約 3 倍に増加。片側PAの割 合 $(42.7 \rightarrow 37.3 \%) 、 \mathrm{ADX}$ 率 $(40.8 \rightarrow 34.9 \%)$ は低下。非 $\mathrm{ADX}$ 率はAVS成功 例 (75.8 vs. $53.4 \%$ )、片側 PA (19.9 vs. $8.6 \%$ ) 共に、日本が有意に高值。非 ADX の $66.6 \%$ で医師が関与し、判断理由は血厈良好、正常 K 血症、合併症 (DMな ど、、CT陰性、AVS結果の乘離など。【結論】両側PAの頻度の高さと片側 例での非ADXがAVSの診断勃率に大きく影響。1）非侵襲的病型診断法の開 発と2）より䈌密に手術適応を考慮したAVS実施が必要。(共同研究者：和 田典男、田辺晶代、Beuschlein F, Caprino MP, Deinum J, Drake W, Fallo F, Fuss CT, Grytaas MA, Darko Kastelan D. Kraljevic I Kocjan T Mulatero P. O'Toole S) (AMED/ JP17ek0109122, JP19ek0109352; NCGM/24-1402, 301008)

\section{1-4-21 副腎静脈サンプリング（AVS）におけるACTH負 荷の臨床的意義について}

小林 洋輝 ${ }^{1} 、$ 阿部 雅紀 ${ }^{1} 、$ 栗原 勲 ${ }^{2} 、$ 一城 貴政 ${ }^{3}$ 、方波見 卓行 ${ }^{4} 、$ 田辺 晶代 $、$ 成瀬 光栄 6 JPAS/JRAS研究班 ${ }^{6}$

日本大学 医学部 腎臓高血压内分泌内科、慶應義熟大学 医学部腎臟内分 泌代謝内科、 ${ }^{3}$ 济生会横浜市東部病院 糖尿病・内分泌セン多一、聖マリア ン十医科大学横浜市西部病院、国立国際医療研究センター 糖尿病内分泌代 謝科、尓京都医療センター 臨床研究センター

【背景】原発性アルドステロン症に扔けるAVS施行時のACTH負荷の臨床的 羲については未確立である。本研究ではAVS中の ACTH負荷が術後のア ウトカム予測に与える影響を明らかにすることを目的とする。方法】 JPAS データベースから、ACTH負荷前後でAVSが実施され副㹂摘出術が行われた 314症例の内、ACTH負荷前の lateralization index (前LI) $\geqq 2$ 加 ACTH負荷 後の LI (後 $\mathrm{LI}) \geq 4$ の群 (Unilateral (U) to U 群, $\mathrm{n}=245$ ); 前 $\mathrm{LI}<2$ かつ後 $\mathrm{LI} \geq 4$ の 群(Bilateral (B) to U群, $\mathrm{n}=15$ ); 前 $\mathrm{LI} \geqq 2$ から後 $\mathrm{LI}<4$ の群 (U to B 群, $\mathrm{n}=54$ )を解 析対象とした。各群における術後 6 个月-1年でのアウトカムを比較検討した。 【結果】U to U 群と比較 LU to B 群では clinical及びbiochemical アウトカムが 有意に悪く、術後病理所見では腺腫の割合が有意に少なかった。又、U to B 群 において clinical及び biochemical アウトカムでいずれも改善を認めた症例で は全症例が病理所見上腺腫であり、重要なことに後LIではなく前LIで区別す ることができた。U to B 群の患者に扰いて良好な術後アウトカムの予測に対 するROC解析では前LIのカットオフを 8.3 とたた時の特異度 $84 \%$ 、感度 $63 \%$ (c statistic, 0.77)であった。【結論】以上より ACTH負荷前後のAVSの結果が術 後アウトカムを予測する上でいずれも有用であることが示された。研究資金 AMED/JP17ek0109122.JP19ek0109352:NCGM/30-1008

\section{1-4-23 KCNJ5およびATP1A1・ATP2B3・CACNA1D 体細胞遺伝子变異陽性アルドステロン産生腺腫の 病理学的特徴}

小野 美澄 ${ }^{1,2}$ 、山崎 有人 ${ }^{3} 、$ 尾股 慧 1,2 、Rainey William $\mathrm{E}^{2}$ Beuschlein Felix 、Mulatero Paulo ${ }^{5} 、$ Carling Tobias ${ }^{6}$ 、伊藤 貞嘉 ${ }^{1} 、$ 笹野 公伸 ${ }^{3}$ 、佐藤 文俊 ${ }^{1}$

${ }^{1}$ 東北大学病院堅・高血压・内分泌科、 ${ }^{2}$ ミシガン大学、 ${ }^{3}$ 東北大学大学院医学 系研究科病理診断学分野、 ${ }^{4}$ ミュンヘン大学、 ${ }^{5}$ 卜リj大学、6 1 イール大学

【背景】原発性アルドステロン症の病因の一つであるアルドステロン産生腺 腫(APA)は脂質が豊富な淡明細胞と好酸性の緻密細胞の 2 種類の腫揚細胞で 主に構成される。APAにおいてKCNJ5を始めとしてATP1A1・ATP2B3 CACNA1D等の体細胞遺伝子変異が近年相次いで報告されている。これら の変異はAPAの約 $90 \%$ 程度で同定されるとされており特にKCNJ5変異は 40-70\%の APAで認め、KCNJ5以外の変異は頻度が少なくいわゆるRare mutation と呼ばれる。これら各変異群における既報の病理学的解析は eyeball estimationによる比較的再現性が低い解析が主であった一方、我々はdigital mage analysis(DIA)による定量的かつ再現性の高い病理組織学的解析手法を 確立している。【方法】米・独・伊各国共同研究施設より提供された KCNJ5 およびATP1A1 ・ ATP2B3・CACNA1Dの各体細胞遺伝子変異陽性 APA 計39症例に対して、DIAを用いて腫瘍内の淡明、繳密各々の練胞成分の割 合やCYP11B2 とCYP17A1発現強度(H-score)を解析した。結果】KCNJ5 とATP2B3群では淡明細胞が緻密細胞に比較して優位であり、ATP1A1と CACNA1Dは淡明細胞と緻密細胞の分布に有意差は認めなかった。CYP11B2 とCYP17A1のH-scoreはKCNJ5群において正相関呈する一方、ATP1A1 群においては負の相関を呈していた。結語】APAにおける最多変異である KCNJ5群はその他Rare mutation 群と比較して異なる特徵を呈することがDIA により示された。

\section{1-4-20 副腎静眽サンプリングにおいて左下横隔静脈は ピットフォールとなるか?}

荒木 拓次 ${ }^{1}$ 、今泉 瑛 ${ }^{1}$ 岡田 大樹 ${ }^{1}$ 、佐々木 優 ${ }^{1}$ 、原井 望 ${ }^{2} 、$ 一條 昌志 ${ }^{2}$ 、土屋 恭一郎 ${ }^{2}$ 、古屋 文彦 ${ }^{2}$ 大西 洋 $^{2}$ 山梨大学 医学部 放射線科、 ${ }^{2}$ 山梨大学 医学部 内科学講座第 3 教室

【目的】副監実質から左下横隔静脈(LIPV)に潜在的吻合が存在する。このこ とからLIPVが副㹂静脈サンプリング(AVS)結果に影響を与えるか否か検討 する。【方法と対象】対象は2017年 2 月から 2019 年7月までに原発性アルドス テロン症と診断され、AVSを施行した連続する65例のうち、左下横隔静脈 (LIPV) が存在し採血可能であった 49 例。LIPV との合流後の副腎静脈共通管 (LAV)、副腎中心静脈(cLAV)、右副腎静脈、下大静脈 (IVC)、LIPV の採血 を ACTH負荷後、15分から 30 分の間で施行し、血墏中アルドステロン (PAC) コルチゾールを測定した。LIPV のPAC とコルチゾール值につき、CLAV IVCと比較した。また、LAVとcLAVを比較した。ACTH負荷後、CLAV、 LAVのコルチゾール值が $200 \mu \mathrm{g} / \mathrm{dL}$ 以上でAVS成功とし、過唾分泌はPAC $\geqq 14000 \mathrm{pg} / \mathrm{mL}$ 、片側性（LR）は>4で有意とした。【結果】 LAVはcLAV に対し、IVCに対するLIPVのコルチゾール值比は、中央值 480\%(範囲 1004112\%)、cLAVに対するLIPVのPAC、コルチゾール值比は、18\%(1.1-185\%)、 15.7\%(2-105\%)であった。1例で、cLAV、LAVで過剩分泌なく、LIPVで過剩 分泌が認められ、LRがcLAVからは右側片側性とされたが、LIPVからは片側 性なしと結果が乘離した。LAVはcLAVに対し、PAC 76\%(22.3-1061\%)、コ ルチゾール值 77\%(14.7-131\%)であった。1例でLAVのみで過剩分泌あり、 外側孤状枝域の腺腫からの左㹂被膜静脈への流出が原因と考えられた。【結語】 LIPV は左副腎から様々な程度で血流を受けている。この中で、過㮃分泌領 域からの血流が主として下横隔静脈へ流出する可能性があり、AVSのピット フォールとなりうる

\section{1-4-22 アルドステロン症において非機能性と診断される 副腎腫摥からも微量のコルチゾール自律分泌があ り予後に影響する}

大野 洋一 ${ }^{1}$ 、曽根 正勝 ${ }^{1}$ 、稲垣 暢也 ${ }^{1}$ 、武田 仁勇 ${ }^{2}$ 、栗原 勲 $^{3} 、$ 立木 美香 ${ }^{4}$ 、一城 貴政 ${ }^{5}$ 、和田 典夫 ${ }^{6}$ 、成瀬 光栄 ${ }^{4} 、 \mathrm{JPAS}$ 研究班 ${ }^{4}$ 京都大学、 ${ }^{2}$ 金沢大学、 ${ }^{3}$ 慶応義塾大学、 ${ }^{4}$ 京都医療センター、 ${ }^{5}$ 横浜市東部病 院、 ${ }^{6}$ 札棍大学

【目的】原発性アルドステロン症では画像上認められる腫瘍がアルドステロン 産生腫瘍とは限らず、両側からのアルドステロン自律產生に非機能性副腎腫 瘍を合併している例もある。そこで非機能性副㷂腫瘍が臨床的に与える影響 に関して検討した。【方法】全国 29 施設共同で構築したPA患者データベース (JPAS)から、副腎静脈サンプリングにて lateralized ratio<2のPA患者データ を抽出し、CT 上で副腎腫瘍あり群となし群の二群に分け、年齢、性別、蛋白 尿、糖尿病といった患者背景や、PAC、PRA、cortisol、ACTH基礎值、1mg デキサメサゾン抑制試験(DST)後の cortisol值といったホルモン值の比較を 行った。さらにホルモン值と腫瘍サイズの相関関係に関して検討した。なお $1 \mathrm{mgDST}$ 後の cortisol值が $1.8 \mu \mathrm{g} / \mathrm{dL}$ 以上の症例は除外した。【結果】196例の 腫瘍あり群と 331 例の腫瘍なし群を比較した所、PAC、cortisol基礎值は両群 で差を認めなかったが、1mgDST 後 cortisol值は腫瘍あり群で有意に高く、糖 尿病、蛋白尿有病率も高かった。さらにACTH、PRAの基礎值は腫瘍あり群 で有意に低かった。患者背景調整後も $1 \mathrm{mgDST}$ 後 cortisol値は腫瘍あり群で 有意に高く、PRA值は有意に低かった。また腫瘍サイズは1mgDST後コルチ ゾール值と正の相関を、ACTH基礎值は負の相関を認めた。【結語】これま で $1 \mathrm{mgDST}$ で cortisol值 $1.8 \mu \mathrm{g} / \mathrm{dL}$ 未満に抑制される副腎腫瘍は非機能性と考 えられていたが、cortisol 自律産生能がないと診断された副腎腫瘍でも微量な cortisol 産生能が存在し、糖尿病や蛋白尿を引き起こす可能性が示唆された。

\section{1-6-1 乳がん内分泌療法に対する耐性予測因子TRIM47 によるNF- $\kappa$ Bシグナル活性化}

東 浩太郎 ${ }^{1}$ 、池田 和博 ${ }^{2}$ 、鈴木 貴 $^{3}$ 、堀江 公仁子 ${ }^{2}$ 、井上 聡 ${ }^{1,2}$ 東京都健康長寿医療センター研究所 システム加齢医学、 ${ }^{2}$ 埼玉医科大学ケ ノム医学研究センター、 ${ }^{3}$ 東北大学大学院医学系研究科

【背景】 TRIM(Tripartite motif-containing)ファミリー蛋白質は、RINGフィン ガー等の共通ドメイン構造を有する 70 以上の蛋白質が同定されており、多く の生理的・病理的現象への関与が報告されている。我々はこれまでに、エスト ロゲン受容体(ER)標的である TRIM 25 が乳がん悪性化に重要であることを明 らかにし、TRIM $25 に$ 近似する構造のTRIM47が前立腺がんの予後覀化因子で あることを最近見出した。

【目的】ER陽性乳がんにおいてTRIM47蛋白質の発現が予後因子になるかを検 討し、さらにその機能を解析することを目的とした。

【対象と方法】倫理基準を満たした術後夕モキシフェン (Tam) 治療を受けた患 者の診断時乳がん組織を、TRIM47抗体を用いた免疫組織化学法による染色強 度と予後との関連性を解析した。乳がん細胞におけるTRIM47 の機能につい て、ER陽性細胞とその $4 \mathrm{OH}-\mathrm{Tam}$ 耐性株を用いて検討した。

【結果】 TRIM47 の強免疫染色性は、術後Tam療法患者の遠隔無再発生存率低 下と有意に相関した。多変量解析において、TRIM47染色性は独立した予後因 子であった。乳癌細胞株において、TRIM47の発現は細胞増殖の促進、40HTam耐性、およびNF- B シグナルの活性化と相関した。また、TRIM47は その結合蛋白質として同定したPRKD3(Protein Kinase D3)の安定化をもたら し、細胞増殖および NF- $\kappa \mathrm{B}$ シグナル活性化に寄与することが示された

【考察】TRIM47は乳がんのホルモン療法耐性化の予後予測因子であり、がん 悪性化にPRKD3の安定化およびNF- $\kappa \mathrm{B}$ シグナル活性化が関わることが示唆 された。TRIM47とその関連因子は、新たな乳がん診断・治療標的となる可能 性が示された。 


\section{1-6-2 悪性裼色細胞腫に対する新規内用療法 $\alpha$ 線放出 薬剤 ${ }^{211}$ At-MABG のマウス褐色細胞腫モデルに おける腫瘍増殖抑制効果の検討 $-\beta$ 線放出薬浏 ${ }^{11}$ I-MIBG との比較}

熟野 弘明 ${ }^{1}$ 、趙 松吉 ${ }^{2}$ 、吉永 恵一郎 ${ }^{1} 、$ 粟生木 美穂 ${ }^{2}$ 、西嶋 剣一 ${ }^{2} 、$ 下山 彩希 ${ }^{2} 、$ 右近 直之 ${ }^{2} 、$ 高 峰英 ${ }^{2} 、$ 暨山 幸信 ${ }^{2} 、$ 伊東 奈津江 ${ }^{1} 、$ 吉岡 菜穂 ${ }^{1} 、$ 田村 菜穂美 ${ }^{3} 、$ 高橋 和弘 ${ }^{2} 、$ 伊藤 浩 $^{4}$ 、東 達也 ${ }^{1}$ 1 量子科学技術研究開発機構 放射線医学総合研究所、2 福島県立医科大学 先 端臨床研究センター、3情報・システム研究機構 統計数理研究所 医療健康 データ科学センター、福島県立医科大学 放射線医学講座

【目的】 $a$ 線を放出する meta- ${ }^{211} \mathrm{At}$-astato-benzylguanidine(MABG)は、転 移性褐色細胞腫や傍神経節腫の治療に従来から用いられる $\mathrm{meta}^{131} \mathrm{I}$ iodobenzylguanidine(MIBG) より高い治療効果が期待されるが、十分な抗腫瘍効 果の検討はなされていない。本研究の目的は、ラット褐色細胞腫 PC-12移植、 ウスにおける ${ }^{211} \mathrm{At}-\mathrm{MABG}$ の腫㰾增殖抑制効果を ${ }^{131} \mathrm{I}-\mathrm{MIBG}$ と比較换討すること である。

【方法】 PC-12細胞移植ヌードマウスに、 ${ }^{211} \mathrm{At}-\mathrm{MABG}(1.11 \mathrm{MBq} / 匹 ： \mathrm{n}=6)$ 、 ${ }^{31} \mathrm{I}-\mathrm{MIBG}(31 \mathrm{MBq} /$ 匹 : $\mathrm{n}=3)$ 又は対照群として溶媒 $(\mathrm{n}=6)$ を尾静脈内投与した。 腫韵体積等を週 3 回観察した

【結果】 投与 14 日後、対照群の腫韵体積は $328.8 \pm 83.7 \mathrm{~mm}^{3}$ から $3568.8 \pm 693.2 \mathrm{~mm}^{3}$

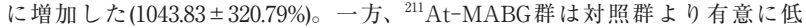
い腫愓体積增加率(\%)を示した $(-5.0 \pm 15.99 \%$ vs. $1043.83 \pm 320.79 \% ： \mathrm{P}<0.001)$ 。 ${ }^{131} \mathrm{I}$-MIBG 群も同様に対照群より有意に低い腫㰾体積増加率を示した $(-34.33 \pm$ $21.39 \%$ vs. $1043.82 \pm 320.79 \%: \mathrm{P}<0.001$ ) 一一方、 ${ }^{211} \mathrm{At}-\mathrm{MABG}$ 群と ${ }^{131} \mathrm{I}-\mathrm{MIBG}$ 群の 間では、体積增加率に有意な差はなかった $(\mathrm{P}=0.052)$ 。

【結論】 薬剤投与14 日後、 ${ }^{211} \mathrm{At}-\mathrm{MABG}$ は対照群に比較し有意な腄場体積縮小効 果を示し、 ${ }^{131} \mathrm{I}-\mathrm{MIBG}$ と同様の効果を示した。 ${ }^{21} \mathrm{At}-\mathrm{MABG}$ は転移性褐色細胞腄 の治療選択肢になる可能性がある。

\section{1-6-4 Acromegaly患者における悪性腫惶発生頻度の検討 〜次世代シークエンサーを用いた高感度、網羅的 miRNAの解析〜}

池田 秀敏 ${ }^{1,2}$ 、池田 拓磨 ${ }^{1,3}$

市たまと体のヘルスケアクリニック神田、総合南東北病院、3岩見沢市立 病院

【緒言】IGF-1は、強力な細胞増殖因子であることが知られている。アクロメ ガリー患者での長期間の高IGF-1 血症、高 GH 血症が悪性腫瘍の発症に促進的 に作用する。アクロメガリー症例で、悪性腫㾔の発生率を検討した。【対象と 方法】アクロメガリーで、集学的治療をおこない，血清IGF-1 值が正常化した 患者 13 例を検討した。男性 5 例、女性 8 例。年龄は 31 歳 $~ 73$ 歳、平均 48 歳で あった。担癌の判定は、われわれが近年開発された、次世代シークエンサー を用いた網羅的 miRNAの解析を行い、その結果のアルゴリズムをExpression score（ES）として坦癌の有無、癌リスクの程度を判定した。ESの特異性は、 $99 \%$ て感度は、直径 0.1 ミリの癌から検出できる精度である。ES と治療前の 最高IGF-1值、高IGF-1血症の罪病期間、悪性腄瘍（甲状腺がん、大腸がん、 乳がん、肺がん、前立腺癌、子宮がん、す心臓がん、食道がん）の発生頻度と の関係を検討した。【結果】 IGF-1值は、545ng/ml。IGF-1值が異常高値を示 した期間は、4.8年であった。早期癌が発見された確率は、13例中 9 例 $(69 \%$ であった。大腸癌、甲状腺癌、前立腺癌、膵楉癌、のいずれもが担癌確率は 0\%であった。一方、肺がん（N=8）のリクは63\%、乳がん（N=4）のリ スクは、50\%、子宮頸がん（N=2）のリスクは、100\%であった。担癌確率と IGF-1值、高IGF-1 血症の罪病期間とに相関は認められなかった。アクロメガ リーでは、IGF-1值、䍜病期間にかかわらず、担癌確率は、50代の対象症例の 癌罹患率の $0.68 \%$ に比べ高かった。結論】アクロメガリー患者の担癌確率を、 マクロRNA解析を用いた高感度の早期がん診断の結果、乳癌、肺がんの担癌 確率が高かった。

\section{1-6-6 小児・AYA世代がん患者の内分泌診療における成 人診療科への移行の現状と問題点}

三善 陽子 ${ }^{1,2}$ 、依藤 亨 $^{2} 、$ 清水 千佳子 ${ }^{3} 、$ 長崎 啓祐 $^{2} 、 川$ 井 正信 ${ }^{2} 、$ 石黒 寬之 ${ }^{2}$ 岡田 賢、菅野 潤子 2 、田久保 憲行 ${ }^{2} 、$ 室谷 浩二 2 、 伊藤 純子 2 堀川 玲子 ${ }^{2}$ 、横谷 進 $^{2} 、$ 大䓟 恵一 ${ }^{1}$

${ }^{1}$ 大阪大学大学院医学系研究科小児科学、 ${ }^{2}$ 日本小児内分泌学会 CCS 委員会、 国立国際医療研究センター乳腺腫場内科

【背景】小児・AYA世代がん経験者は内分泌異常の発症リスクがあり、長期 フォローアップのために小児科から成人診療科への円滑な移行（トラシジショ ン) が求められる。

【目的】がん患者の内分泌骖療に扔ける移行期医療の問題点の解明

【対象と方法】日本小览内分泌学会評議員(183名、137施設)を対象とし、施設 代表者1名が質問紙に回答。

【結果】アンケート回答数 131 部、回答評議員数 174 名、回答率 $95.1 \%$ 。1）施 設の診療状況：小児がん治療医 $(50 \%)$ 、内分泌代謝内科医 $(65 \%)$ 、長期フォ ローアップ外来 (44\%) は一定数存在したが、移行支援プログラム $(8 \%)$ と 移行支援チーム $(7 \%)$ は少数であった。2) 移行期医療についての考元; 移行 期患者の診療の主な担い手として望ましいのは成人内分泌医 $(89 \%) 、$ 、診療を 引き受けてくれる成人諩療科医は存在する（89\%）と考えていたが、やや不足 $(42 \%)$ ，大幅に不足 $(26 \%)$ と感じていた。最近 1 年間に移行した患者数は $89 \%$ が 4 名以下と少数だった。 3 ) 移行期医療の問題点 : 妊㝋性 $(64 \%)$ 、肥满 $(35 \%)$ 、妊娠・分婏 $(30 \%)$ 、性腺機能異常 $(30 \%)$ の順で診療に困難感あり と回答。医療側では人員や診療時間の不足、患者側では複数診療科の受診（専 門分化）、家庭側では親（過保護、過干渉）が負担の最上位にあげられた。

【まとめ】小児・AYA世代がん患者の移行期には世代特有の問題点が多数存在 するため支援体制が必要と考えられた。

【結語】小児・AYA世代がん患者の長期健康管理に向けて診療科間の連携が重 要である。

\section{1-6-3 HOXC遺伝子を軸としたビタミンD3によるヒト 前立腺癌の抗增殖作用の分子機序}

諏佐 崇生 ${ }^{1}$ 、小高 尚貴 ${ }^{2} 、$ 飯塚 眞由 ${ }^{1}$ 、安達 三美 ${ }^{1} 、$

渡部 多真紀 ${ }^{3}$ 、渡辺 茂和 $^{2}$ 、岡崎 具樹 $^{1}$

${ }^{1}$ 帝京大学 医学部 生化学講座、 ${ }^{2}$ 帝京大学 薬学部 薬学実習推進研究セン

夕ー、3 帝京大学 薬学部 実務薬学研究室

前立腺癌はDHTなどのアンドロゲン依存的に増殖するに対し、活性型ビタミ ンD3（D3）は逆に増殖を抑制する。D3はアポトーシスを惹起した抗増殖作用 を前立腺癌に示すが、その作用がアンドロゲン依存的とも報告されており、そ の分子機序の全てが明らかであるとは言えない。そこで本研究では、ヒト前立 腺癌 $\mathrm{LNCaP}$ 細胞における DHT と D3の標的遺伝子を網羅的に解析することか ら、D3に上る抗増殖機序の解析を試みた。

DHTとD3を投与したLNCaP細胞の遺伝子発現を網羅的に解析した結果、 HOXC9の発現がDHTにより 0.36 倍に抑制され、一方D3には 2.77 倍に促進さ れることを見出した。HOXC遺伝子の内、HOXC9 と 13 の 2 遺伝子が共通した 拮抗的な制御を受けていた。DHTによる転写抑制は5-Azacitizine（5-Aza） により解除されたことから DNAのメチル化を介した転写抑制であると考え られた。さらにここのHOXC9 発現が抑制されない5-Aza処理時において、 DHTにより促進されるPSAなどの標的遺伝子の発現も減弱していた。ルシ フェラーゼアッセイでの検証から、HOXC9 と 13 は ARの DHT 依存性なプロ モーター活性を減弱させることが明らかとなった。

本研究により、LNCaP細胞においてDHTはARの転写活性を阻害する HOXC9 13 の発現をDNAのメチル化を介して抑制することで、ARが機能 して増殖し易い細胞内環境を形成していると考えられた。一方、D3はHOXC9 と13の発現を促進することでARの機能を妨害していると考えられ、これが D3による抗増殖作用の分子機序の一端であると考えられた。

\section{1-6-5 血清テストステロン低下率 $95 \%$ は、前立腺癌ホル モン療法患者の予後を予測する}

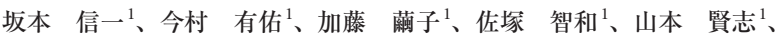

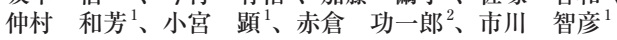

千葉大学医学部付属病院 泌尿器科、 ${ }^{2} \mathrm{JCHO}$ 東京新宿メディカルセンター

【目的】過去に我々は、Nadir テストステロン（TST） $20 \mathrm{ng} / \mathrm{dL}$ が予後と関連 することを報告した。今回、我々は、血清テストステロン低下率と予後との 関連について解析したので報告する。【方法】2013年4月から 2017 年 9 月まて の期間、当院でホルモン療法施行した前立腺癌患者 222 例につき、一次内分泌 療法中の血清テストステロン（TST）值を含めた臨床因子と予後（無増悪生 存期間：PFS と全生存期間：OS）との関連について統計学的に解析した。【結 果】患者年齢の中央值 73歳。観察期間は、中央值で 44.7 か月であった。PSA と治療前TSTの中央值はそれぞれ、86.0 ng $/ \mathrm{ml} 、 482 \mathrm{ng} / \mathrm{dl}$ であった。PFSに 関して、多変量解析の結果、Nadir PSA (HR 4.65, p<0.0001) と Nadir TST $\geqq$ $15 \mathrm{ng} / \mathrm{dL} （ \mathrm{HR} 0.29, \mathrm{p}=0.006$ ） とが独立した予測因子であった。TST低下 $\geqq$ $95 \%$ はFSと関連を認めなかった $(\mathrm{p}=0.414)$ OSに関しては、単変量解 析にてNadir TST $\leqq 20 \mathrm{ng} / \mathrm{dL}$ と TST低下 $\geqq 95 \%$ が有意な因子として残る 中、多変量解析ではTST 低下 $\geqq 95 \%$ が唯一の独立した予測因子であった（HR 0.29、 $\mathrm{p}=0.015)$ 。Kaplan Meier生存曲線に打いても、TST低下 $\geqq 95 \%$ を達成 した症例は、有意にOSを延長した $(\mathrm{p}<0.001)$ 。二群解析では、TST低下 $95 \%$ を详成した症例は、有意に治療前TST值が高く（523ng/dL vs $411 \mathrm{ng}$ / dL)、Nadir TSTが低く(8.5ng/dL vs $26 \mathrm{ng} / \mathrm{dL}) 、 N a d i r$ TSTまでの期間が長 い(428day vs 194day) 結果であった。【結論】前立腺癌ホルモン療法患者に おいて、血清 TST の低下率がNadirの值以上に予後を予測する上で有用な可 能性が示唆された。

\section{1-8-1 甲状腺の内部エコー不均一は甲状腺自己抗体陽性 者における抗PD-1 抗体関連甲状腺障害の高リス クマーカーとなる}

岡田 則男、岩間 信太郎、伊藤 雅晃、奥地 剛之、小林 朋子、 安田 康紀、有馬 寬

名古屋大学大学院 糖尿病 - 内分泌内科学

【背景】甲状腺自己抗体は抗PD-1抗体による甲状腺障害の高リスクマーカー であることを報告したが、甲状腺自己抗体陽性例においてリスクを判別でき る指標はない。【目的】甲状腺自己抗体陽性例における甲状腺エコー所見と抗 PD-1抗体による甲状腺障害発症との関連を明らかにする。【対象と方法】当院 で抗PD-1抗体を使用した 209 例について、治療開始前と開始後 6 週毎に 24 週 後まで甲状腺機能を測定、24 週以降は臨床上必要と判断した場合に甲状腺機 能を評価。抗PD-1抗体治療開始前に甲状腺自己抗体(抗サイログロブリン抗 体および抗TPO抗体)を湘定し、いずれかが陽性であった場合は甲状腺エコー を施行。【結果】209例中、19例 (9.1\%)で破壊性甲状腺炎または甲状腺機能低下 症 (TD)、1例で甲状腺機能充進症が認められた。治療開始前の甲状腺自己抗体 陽性例の TD 累積発症率は、陰性例に比べ有意に高値[15/44 (34.1\%) vs. 4/165 $(2.4 \%), \mathrm{p}<0.001$ 。甲状腺自己抗体陽性 42例について甲状腺内部エコーを評 価内部エコー不均一例のTD累皘発症摔は、均一例に比べ有音に高值 $[13 / 23$ (56.5\%) vs. 1/19 (5.3\%), p = 0.001]。24 週以降にTDの発症は認めなかった。【考 察】抗PD-1抗体による TDは投与開始後 24 週以内に認められ、そのリスクは 投与開始前の甲状腺自己抗体と甲状腺内部エコー所見により判別できること が示された。【結語】甲状腺自己抗体と甲状腺内部エコーを評価することで抗 PD-1抗体によるTDのリスクを判別できる。 


\section{1-8-2 免疫チェックポイント阻害薬による甲状腺機能障 害の発症に関する検討}

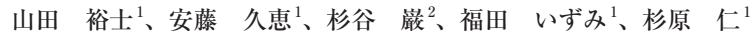
${ }^{1}$ 日本医科大学大学院医学研究科 内分泌糖尿病代謝内科学分野、 ${ }^{2}$ 日本医科 大学大学院医学研究科 内分泌外科学分野

【背景】免疫チェックポイント阻害薬による免疫関連副作用 (irAE) は時に重篤 な転帰を来たすが発症機序や詳細な経過はまだ不明な点も多い。【目的】当院 での免疫チェックポイント阻害薬による甲状腺機能障害の臨床像について検 討した。【方法】 2014〜2019年の期間に免疫チェックポイント阻害薬投与後 に甲状腺機能障害をきたした 21 例について発症前の状況、甲状腺機能障害の 経過、合併症などを検討した。【結果】男性/女性は13/8名で平均年齢は 65.8 \pm 2.1 歳、原疾患は肺癌 17 、腎癌 2 、悪性黑色腫 1 、中咽頭癌 1 名で使用薬剤は pembrolizumab 8、nivolumab 7、atezolizumab 4、durvalumab 2名であった。 $17 / 21$ 例 (80.0\%) で破壊性甲状腺炎を呈した。治療前後で甲状腺自己抗体を測 定した 8 例中 3 例で薬剤投与後に自己抗体の陽転化を認めた。一方、治療前後 とも陰性の症例が 3 例、治療前後とも陽性が 2 例であった。薬剤投与開始から 発症までの期間は $85.5 \pm 21.7$ 日、投与回数は $5.8 \pm 1.4$ 回で薬剤間に有意差はな かった17例でチラージンSの補充を要した。合併症としてACTH単独欠損 症 4 例、劇症 1 型糖尿病 1 例、小脳炎 1 例が認められた。【考察】 irAEの発症 を予測するバイオマーカーとして甲状腺自己抗体やHLAの関与が示唆されて いるが、今回の検討では抗体が陽転化した症例と陰性のままの症例が認めら れており、自己抗体のみでは説明し得ない発症機序が存在するものと考えら れた。またACTH単独欠損症の合併も $20 \%$ に認めることから irAEの適切なマ ネージメントが必要である。

\section{1-8-4 46,XY DSDのみを呈するMYRF遺伝子変異陽性患} 者

大久保 由美子 ${ }^{1}$ 、村井 雄紀 ${ }^{1}$ 、寺尾 紗世 ${ }^{1}$ 、佐久間 美佳 ${ }^{1} 、$

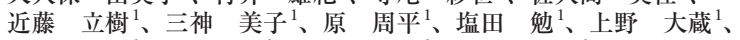
太田 達樹 ${ }^{1} 、$ 佐藤 恵 ${ }^{1} 、$ 森下 雄大 ${ }^{1}$ 、福岡 哲哉 ${ }^{1} 、$ 増永 陽平 ${ }^{2} 、$ 緒方 勤 ${ }^{2}$

${ }^{1}$ 静岡済生会総合病院 小览科、 ${ }^{2}$ 浜松医科大学 小览科

【背景】MYRFは体腔上皮の発生分化に必須の遺伝子である。最近、MYRF のへテロ変異が、46,XXと 46,XY性分化疾患、中枢神経異常、横隔膜へルニ ア、心奇形など、体腔上皮由来の臓器・組織に打いて多彩な臨床症状を招く ことが報告されている。われわれは、46,XY DSDのみを呈するMYRF遺伝 子変異陽性患者を同定したので報告する。【症例】39週6日、2856g で出生し た社会的男児である。胎児期の超音波検査では性別は女児と判定されていた。 日齢 4 日、性分化疾患のため当院内分泌外来を紹介された。小精巣 $(<1 \mathrm{~mL})$ 、 小陰茥 (㓌茥長 $1 \mathrm{~cm}$ )、停留精巣 (両側鼠径部)、尿道下裂（陰茎基部開口 型）が認められ、染色体は46,XY (SRY+)であった。生後7カ月時、GnRH 試 験でLH $0.3 \rightarrow 8.4 \mathrm{mIU} / \mathrm{ml}$, FSH $3.4 \rightarrow 23.9 \mathrm{mIU} / \mathrm{ml}$. hCG 試験で testosterone $0.03 \rightarrow 0.78 \mathrm{ng} / \mathrm{ml}$ と、高ゴナドトロピン性精巣機能不全が認められた。また、 $\mathrm{AMH}$ は $15.0 \mathrm{ng} / \mathrm{mL}$ と低值であった。全エクソーム解析でMYRFに de novo c.1301A >C:p.(Gln443Pro)へテロ変異が同定された。これは、一般集団に存在 せず、高度に病原性を有すると評価された。他にDSDを発症する遺伝子に異 常は認められなかった。【考察】以上の所見は、MYRFのへテロ変異が $46, \mathrm{XY}$ DSDのみを招きうることを示すものである。さらに、DSDの原因が、精巣形 成不全およびそれに起因する男性ホルモン產生低下に起因することを示唆す る。

\section{1-8-6 $11 \beta$ 水酸化酵素欠損症に対するAAVベクターに よる遺伝子治療の試み}

内木 康博 ${ }^{1}$ 、宮戸 真美 ${ }^{2}$ 、堀川 玲子 ${ }^{1}$ 、高田 修治 ${ }^{3}$ 、勝又 規行 $^{2}$ 、 深見 真紀 ${ }^{2}$

${ }^{1}$ 国立成育医療研究センター 内分泌代謝科、 ${ }^{2}$ 国立成育医療研究センター研 究所 分子内分泌研究部、 ${ }^{3}$ 国立成育医療研究センター研究所 システム発生. 再生医学研究部

【背景】これまでに 21 水酸化酵素欠損症モデルマウスに副腎皮質外にアデノ ウィルス随伴ウィルスベクター (AAV)でCyp21a1 遺伝子を導入することでス テロイド代謝が改善し、患者線維芽細胞にAAVによる遺伝子導入によって 21 水酸化酵素の活性が得られたが $11 \beta$ 水酸化酵素欠損症では得られなったこ とを報告した。今回は $11 \beta$ 水酸化酵素欠損症モデルマウスに対する遺伝子導 入を試みたので報告する。【目的】11 $\beta$ 水酸化酵素欠損症モデルマウスを作成 し、副㹂へAAVで遺伝子導入することでステロイド代謝が改善するかを検 証した。【方法】ゲノム編集技術を用いCyp11b1 欠損マウス（Cyp11b1D）を 作成した。Cyp11b1を含んだ血清型9型AAV (AAV9-Cyp11b1) を作製し た。Cyp11bDの背部から目視下に左副腎にAAV9-Cyp11b1を注入した。投 与前、投与後 5 か月まで1か月毎にマウス血清中のデオキシコルチコステロン (DOC) とコルチコステロン (B)をLC-MS/MSで測定した。遺伝子の発現はRT - PCRを用いて確認した【結果】作成したマウス血清中の DOC/B比は著し く上昇して抢り生化学的に $11 \beta$ 水酸化酵素欠損を確認した。このCyp11b1D に対してAAV9-Cyp11b1接種後1か月より著明に改善し、投与後5か月まで 持続した。欠損症マウスに扔いて副腎皮質の久損酵素の上流のCyp11a1遺伝 子の発現増加とCyp $11 \mathrm{~b} 1$ 遺伝子の発現低下、さらにべクター注入側に扔ける Cyp11b1遺伝子の発現増加はわずかであることを認めた。【結語】CYP11B1な どミトコンドリア性ステロイド合成酵素欠損においてAAV9ベクターを用い た副腎内への遺伝子導入による遺伝子治療の可能性を示唆する。

\section{1-8-3＼cjkstart兔疫チェックポイント阻害剤による甲状腺障害の バイオマーカー}

栗本 千晶、稲葉 秀文、北原 千愛、小瀬川 真美、中尾 友美、 上田陽子、过 智也、浦木 進丞、竹島健、山岡 博之、 森田 修平、古川 安志、岩倉浩、有安宏之、古田浩人、 西 理宏、赤水 尚史 和歌山県立医科大学 内科学第一講座

【背景】免疫チェックポイント阻害剂（ICI）治療は効果的ながん免疫療法で ある一方で、高率に内分泌免疫関連有害事象 (irAE) を発症する。特に甲状 腺irAEが高頻度に発症するが、その予測因子については十分解明されていな い。そこで我々は、甲状腺 irAE早期診断のバイオマーカーとなりうる因子に ついて検討を行った。【方法】当院でICI療法（抗PD1抗体、抗CTLA-4抗 体、または併用療法）を受けた進行悪性疾患（悪性黒色腫、非扁平上皮肺癌、 胃癌、腎細胞癌、尿路上皮癌）の患者に対し、24か月間前向きの観察を行っ た。生化学検查、甲状腺機能、甲状腺自己抗体はベースライン時抢よびICIの 初回治療後 4 週間ごとに評価し、サイトカイン/ケモカインはベースライン時 と4週間後に測定した。【結果】ICI治療を受けた悪性疾患の患者 26 名に対し て解析を行った。甲状腺irAE発症群(13名)とirAE非発症群(13名)の 2 群間で 比較すると、irAE発症群のほうがベースライン時の甲状腺自己抗体陽性例が 多かった。血清サイログロブリン $(\mathrm{Tg})$ 值と甲状腺自己抗体の早期增加（4週 間以内）がirAE発症群で見られた $(\mathrm{P}<0.05)$ 。ベースラインでの IL-2等の高 值、抢よびIL-8等の早期減少は、甲状腺 irAEの発症と有意な相関が見られた $(\mathrm{P}<0.05)$ 【結論】 Tg、甲状腺自己抗体、およびサイトカインレベルの早期変 化が甲状腺 irAEのバイオマーカーとなる可能性が示唆された。

\section{1-8-5 先天性副腎過形成の新生児マス・スクリーニングで は日齢 11 までに治療開始できる体制が求められる}

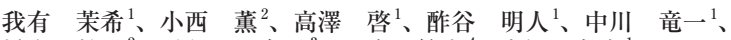
橋本 敦子 ${ }^{2}$ 、長谷川 奉延 ${ }^{3}$ 、田島 敏広、森尾 友宏 ${ }^{1}$ 、 鹿島田 健一

${ }^{1}$ 東京医科歯科大学 発生発達病態学分野、 ${ }^{2}$ 東京都子防医学協会母子保健検 査部 小児マススクリーニング科、 ${ }^{3}$ 慶應義塾大学医学部 小児科学教室、 ${ }^{4}$ 自 治医科大学 とちぎ子ども医療センター小児科

【背景】先天性副腎過形成(CAH)の新生児マス・スクリーニング(NBS)では、 来院時に塩泼失を来している症例は少なくない。安全なNBSのためには重篤 な塩袈失を生じる前に治療を開始する必要があるが、adrenal crisisの発症予 防とNBSの適正なあり方を精査時の児の状態から検討した報告はない。【目 的】CAHの適正なNBSのあり方を治療開始時の塩䘫失の状態から検討する。 【方法と結果】1989〜2017年度に初回精査となった古典型CAH 100 人を対象 とし後方視的に検討を行った。受診時の血清 $\mathrm{Na}$ 值と $\mathrm{K}$ 值は有意に負の相関 を示し $\left(\mathrm{R}^{2}=0.37\right.$ )、血清 $\mathrm{Na} 130 \mathrm{mEq} / \mathrm{L}$ に相当する血清 $\mathrm{K}$ 值は $6.7 \mathrm{mEq} / \mathrm{L}$ 、この 時の $\mathrm{Na} / \mathrm{K}$ 比は19.4であった。以上より $\mathrm{Na}<130 \mathrm{mEq} / \mathrm{L} 、 \mathrm{~K}>7 \mathrm{mEq} / \mathrm{L} 、 \mathrm{Na} /$ K比く20のいずれかを満たす場合を、生命を脅かす危険がある重篤な塩裝失 (severe salt losing: SSL) と定義した。受診日齢と血清 $\mathrm{Na}, \mathrm{Na} / \mathrm{K}$ は負の相関 $\left(\mathrm{R}^{2}=0.38, \mathrm{R}^{2}=0.34\right)$ 、受診日齢と血清 $\mathrm{K}$ は正の相関を示した $\left(\mathrm{R}^{2}=0.25\right)$ 。SSLを呈 する予測日齢はそれぞれ11.1日，10.9日，12.2日であった。SSLは1例を除き日 齢7以降に出現し、その割合は日齢7-11では $45.0 \%(27 / 60)$ であるが、日齢 12

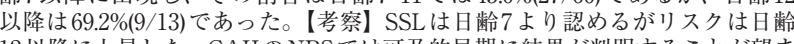
12 以降に上昇した。CAHのNBSでは可及的早期に結果が判明することが望ま しいが、遅くとも日齢 11 までに治療開始できる体制が必要と考えられる。【結 論】CAHのNBSでは遅くとも日齢 11 までに治療開始する体制が必要である。

\section{1-9-1ラット下垂体の生後におけるラトケ遺残腔の観察}

堀口 幸太郎 ${ }^{1,2}$ 、藤原 研 ${ }^{3}$ 、吉田 彩舟 ${ }^{2}$ 、中倉 敬 ${ }^{4}$ 、塚田 岳大 ${ }^{5}$ 、

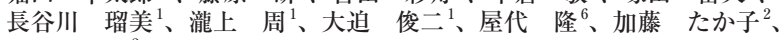
加藤 幸雄 $^{2}$

杏林大学 保健学部、 ${ }^{2}$ 明治大学 内分泌研、 ${ }^{3}$ 自治医科大学 医学部、 ${ }^{4}$ 帝京大 学 医学部、 ${ }^{5}$ 東邦大学 理学部、 ${ }^{6}$ 帝京平成大学 健康メディカル

下垂体前葉は、5種類のホルモン産生細胞と、SOX2 陽性の幹・前駆細胞、濾 胞星状細胞、毛細血管を形成する内皮細胞および周皮細胞などから構成され る。これらの細胞群の中で、SOX2 陽性の幹・前駆細胞は、ラトケの遺残腔 に接する中葉と前葉にまたがる Marginal Cell Layer (MCL) や実質層に局在 乙、他の下垂体構成細胞を供給すると考之られている。我々は、膜タンパク 質CD9がラット下垂体の前葉側抢よび中葉側 MCL と実質層のSOX2 陽性細胞 のほとんどに発現し、後葉および中葉の害質層では陰性であることを見出して いる。すでに、CD9の抗体を利用して、前葉側 MCL と実質層のCD9 陽性細胞 の分画法を樹立し、特性を報告した。さらに、中葉側 MCLと前葉側 MCL の SOX2 陽性細胞群の形態的、機能的な違いの有無を明らかにするために、本研 究では、生後初期から成体期における光学顕微鏡および走査型電子顕微鏡によ る MCLの観察、そしてCD9/SOX2二重陽性細胞の単離およびホルモン産生細 胞への分化能の有無を調べた。その結果、中葉側 MCLの $25 \%$ が線毛を有する 細胞であり、その $99 \%$ がCD9 陽性であった。線毛細胞の数は生後 5 日齢に比 べ、成体期において倍増することも明らかとなった。一方、前葉側 MCLでは、 線毛細胞の割合は $3 \%$ ほどで日齢による変化は観察できなかった。次に、中葉 側 MCL の CD9 陽性細胞の単離を行い、単離したCD9陽性細胞は pituisphere 形成能をもち、前葉の5種のホルモン産生細胞に分化した。これらは、ラット 下垂体の中葉側 MCL も前葉実質層の細胞供給部位である可能性を強く示唆す る結果である。 


\section{1-9-2＼cjkstart兔疫チェックポイント阻害薬による下垂体障害に 関連する自己抗体の網羅的解析}

奥地 剛之、岩間 信太郎、伊藤 雅晃、岡田 則男、小林 朋子、 安田 康紀、有馬 宽

名古屋大学大学院 医学系研究科 糖尿病 - 内分泌内科学

【背景】免疫チェックポイント阻害薬（ICI）関連下垂体障害の高リスクマー カーは明らかではない。【目的】ICI関連下垂体障害の高りスクマーカーとな り得る自己抗体をプロテインアレイによる網羅的解析で同定する。【方法】イ ピリムマブ誘発下垂体炎 $(\mathrm{Ipi}-\mathrm{H})$ 発症 3 例、非発症 2 例と、抗PD-1抗体誘発 ACTH 単独欠損症 (PD-1-IAD) 発症 3 例、非発症 2 例の治療開始前血清を用 い、プロテインアレイによる網羅的解析から各々に特異的な自己抗原候補を抽 出した。次に, Ipi-H発症 4例、非発症9例と、PD-1-IAD 発症10例、非発症 14例の治療開始前血清を用い、抽出した候補蛋白に対する自己抗体を ELISA で定量評価した。また、マウス下垂体における候補蛋白の発現を免疫組織化 学(IHC)で解析した。【結果】プロテインアレイにより、自己抗原候補として Ipi-Hで8種、PD-1-IADで6種をそれぞれ抽出した。ELISAにおいて、Ipi-H の 8 種中 3 種、PD-1-IAD の 6 種中 5 種で発症例の抗体価が非発症例と比べ有意 に高值であったIHCでは、Ipi-Hで同定された3種の候補蛋白の下垂体にお ける発現が認められた。【結語】ICI関連下垂体障害発症例の治療開始前血清 に拈いて高抗体価を示す新規自己抗体を Ipi-Hで 3 種、PD-1-IAD ゙ 5 種同定 した。これらの自己抗体は、ICI関連下垂体障害の高リスクマーカーとなる可 能性が示唆された。

\section{1-9-4 脳一脾相関からみた肥満による全身性慢性炎症の 発症メカニズム}

後藤 孔郎 ${ }^{1} 、$ 吉田 雄一 ${ }^{1} 、$ 尾関 良則 ${ }^{1} 、$ 穴井 学 ${ }^{1} 、$ 岡本 光弘、 正木 孝幸 ${ }^{1}$ 加隈 哲也 ${ }^{2}$ 、柴田 洋孝

${ }^{1}$ 大分大学 医学部 内分泌代謝 - 膠原病 - 腎臓内科学講座、 ${ }^{2}$ 大分大学 保健管 理センター

【目的】我々は、肥満による脾臓からのIL-10発現低下が多臓器に炎症性変化 をもたらすことを明らかにしている。しかし肥満がどのようなメカニズムで脾 臓由来IL-10発現を低下させるのかについては、不明のままである。近年、肥 満による脳内ミクログリアの活性を抑制させると、中枢神経内で炎症性変化の みならず末梢臟器での炎症性変化も軽減されるという報告がある。また以前よ り、中枢神経から脾臓への遠心性神経が存在することが知られている。今回、 肥満による脳内での炎症性変化を抑制させることが脾臓への遠心性神経を介し て脾臟由来IL-10合成および末梢臓器に影響を及ほすすか検討した。【方法】食 事誘導性肥満雄ラットを脾臟への遠心性神経切断（SpX）群と非切断（Sham） 群に分ける。さらに各群に対してIL-10中枢投与群と PBS群に分ける。1）脾 臟内での IL-10発現、IL-10産生に関与する制御性T細胞発現、2）炎症性、 クロファージ (M1) 浸潤や炎TNF- $\alpha$ 発現による小腸内炎症性変化、を評価 項目とした。【成績】1) 肥満モデル動物にIL-10を中枢投与すると脾臟内の IL-10合成および制御性 T 細胞の発現が増加するが、その増加が SpXにより消 失した。また、IL-10中枢投与により脾臓内での NGF含有量が増加し、SpX によってその増加が抑制された。2）小腸内の炎症性変化についても、IL-10 中枢投与により小腸内 M1 浸潤や TNF- $\alpha$ 発現が抑制されるが SpXによってこ のような変化が消失した。【結論】肥満による小腸の炎症性変化には、中枢神 経内での炎症性変化による遠心性神経を介したNGF分泌および脾臟IL-から の10発現低下が関与していると推測された。

\section{1-9-6 血漿中XOR活性と血管内皮機能との関連}

藏城 雅文 ${ }^{1}$ 、福本 真也 ${ }^{2}$ 、吉田 潮 $^{1}$ 、村瀬 貴代 ${ }^{3}$ 、中村 敬志 $^{3}$ 、 吉田 寿子 ${ }^{4}$ 、森岡 与明 ${ }^{1}$ 、森 克仁 ${ }^{5}$ 、今西 康雄 ${ }^{1}$ 、絵本 正憲 ${ }^{1}$ ${ }^{1}$ 大阪市立大学大学院医学研究科 代謝内分泌病態内科学、 ${ }^{2}$ 先端予防医療学、 ${ }^{3}$ 三和化学研究所 三重研究パーク、 ${ }^{4}$ 医療統計学、 ${ }^{5}$ 腎臓病態内科学

【背景】キサンチン酸化還元酵素(XOR)は、尿酸㧍よび活性酸素を産生する 酵素である。XOR阻害薬の投与は、血管内皮機能を改善させるが、血清尿酸 值の変化とは関連しないことが明らかとなっている。しかしながら、血漿中 XOR活性と血管内皮機能との関連性は明らかではない。【方法】対象は先端予 防医療附属クリニック MedCity 21 の人間ドックを受診し、血清尿酸值に影響 を及ほす薬剤を服用していない193名(男性91名、女性102名)。血槳中XOR 活性、血清尿酸值を測定し、上腕動脈血流介在血管拡張反応 $(F M D)$ との関連 性を横断的に検討した。なお、血漿中XOR活性は (株) 三和化学研究所で確 立した安定同位体基質として $[13 \mathrm{C} 2,15 \mathrm{~N} 2]$ キサンチンと三連四重極質量分析計 (LC/TQMS) を利用した方法で評価した。【結果】血漿中XOR活性、血清尿酸 值、FMDの中央值はそれぞれ $26.1 \mathrm{pmol} / \mathrm{h} / \mathrm{mL} 、 5.6 \mathrm{mg} / \mathrm{dL} 、 6.2 \%$ あった。 血漿中 XOR活性、血清尿酸値及び年齢、性別、高血圧、糖尿病、脂質異常、 喫煙、心血管既往の有無、内臓脂肪面積、eGFRを含む重回帰分析において、 血漿中XOR活性 $(\beta=-0,113, \mathrm{p}=0.168)$ おょび゙血清尿酸值 $(\beta=0.020, \mathrm{p}=0.836)$ は FMD と有意な関連性を認めなかった。しかしながら、血漿中XOR活性は、非 高血圧群 (138名) $(\beta=-0.211, \mathrm{p}=0.031, \mathrm{p}$ for interaction $=0.053)$ 、非糖尿病群 $(168$ 名) $(\beta=-0.151, \mathrm{p}=0.080, \mathrm{p}$ for interaction $=0.104)$ では、FMD と負の関連性を認 めたが、血清尿酸值は有意な関連性を認めなかった。【結論】心血管リスクの 低い群において、XORがROS産生を介し、血管内皮機能障害に寄与している ことが示唆された。

\section{1-9-3 ラット下垂体に存在する運動線毛保有細胞の分子 形態学的性質}

中倉 敬 ${ }^{1} 、$ 鈴木 健史 ${ }^{2} 、$ 堀口 幸太郎 ${ }^{3} 、$ 藤原 研 ${ }^{4,5}$ 、塚田 岳大 ${ }^{6}$ 、 萩原 治夫 ${ }^{1}$

${ }^{1}$ 帝京大学 医学部 解剖学講座、 ${ }^{2}$ 札医大 医育 生物、 ${ }^{3}$ 杏林大 保健、 ${ }^{4}$ 自治医 大 医 解剖、 ${ }^{5}$ 神奈川大 理、 ${ }^{6}$ 東邦大 理 生物分子

下垂体の前・中葉間に位置する一層の特殊な細胞層 Marginal cell layer (MCL) や前葉の実質内部には、ホルモンを合成しないS100 $\beta$ タンパク質陽 性の細胞集団が存在している。近年の研究から、その多くが幹細胞マーカー SOX2を発現するとともに、ホルモン産生細胞への分化能を有するなど、下垂 体の構造形成や機能維持に不可欠な、多様性を持った細胞群であることが明ら かになりつつある。興味深いことに、MCLや前葉内の濾胞構造には運動線毛 を保有する上皮系細胞（以下、線毛細胞）が存在することが報告されている。 一般的に、運動線毛は物質や細胞の攪挥・運搬に加え、細胞外環境の化学セン サーとして働くことが知られるが、下垂体線毛細胞に打ける細胞生物学的性 質や役割に関する知見は乏しい。このため本研究では、アセチル化 $\alpha$-tubulin (線毛マーカー)、 $\gamma$-tubulin（基底小体マーカー）、S100 $\beta$ 、SOX2、㧍よび運 動線毛の形成に必須の転写因子FOXI1 を対象に峃光免疫染色を行うことで、 下垂体線毛細胞の分子形態学的性質について調べた。その結果、下垂体線毛細 胞はSOX2 と FOXJ1を特異的に発現する新規のS100 $\beta$ 陽性細胞であり、MCL や前葉実質の濾胞構造はS100 $\beta$ /SOX2/FOXJ1陽性線毛細胞とS100 $\beta$ /SOX2 陽性非線毛細胞により構成されていることが明らかとなった。しかし、下垂体 に打ける線毛細胞の存在意義についてはいまだ不明なため、今後は下垂体機能 との関係を調べる必要がある。

\section{1-9-5 脂肪肝再生過程で生じる細胞死の新規誘導メカニ ズム}

稲葉 有香 ${ }^{1}$ 、橋内 咲実 ${ }^{2}$ 、小川 千尋 ${ }^{2}$ 、渡邊 一史 ${ }^{1}$ 、井上 啓 ${ }^{1,2}$ ${ }^{1}$ 金沢大学 新学術創成研究機構 栄養 · 代謝研究ユニット、 ${ }^{2}$ 金沢大学 医薬保 健学総合研究科 代謝生理学分野

【背景】肝細胞死の増加は、脂肪肝再生障害を引き起こし、非アルコール性脂 肪性肝疾患の進行に関与する。高度脂肪肝では、肝再生過程の細胞内ストレス 応答が増大し、細胞死（アポトーシス・ネクロプトーシス）が誘導され、重篤 な肝障害を引き起す。我々は、この高度脂肪肝再生過程では、ストレス誘導 性転写因子ATF3の発現が増加することを見出している。【目的】高度脂肪肝 再生過程で生じる細胞死誘導において、ATF3が果たす役割を解明する。【方 法】高度脂肪肝モデルの作成は、ATF3 欠損マウスおよび野生型マウスに対㐫 る16週間の高脂肪食負荷により行った。高度脂肪肝を $70 \%$ 切除した後、再生 過程の肝臓及び血漿を採取した。肝障害を血漿 ALT值により評価した。肝細 胞死をTUNEL染色により、細胞死様式をTUNEL・活性型カスパーゼ 3 蛍光 二重染色により評価した。遺伝子発現を定量PCR、タンパク発現をウエスタ ンブロットにより評価した。【結果】肝臟切除前の脂肪肝の程度は、両群で同 等であった。ATF3 久損群では、高度脂肪肝再生過程のALT值が低下し、肝 細胞死が減少した。特に、対照群で発症した広沉細胞死が、ATF3 欠損群では 認められなかった。さらに、TUNEL・活性型カスパーゼ 3 蛍光二重染色の結 果から、ネクロプトーシスがATF3欠損群で減少したことが明らかになった。 遺伝子発現・タンパク発現の検討では、ネクロプトーシス関連因子の発現が、 ATF3欠損群で有意に減少した。一方、アポトーシス関連因子の発現は、対照 と同程度であった。【結論】高度脂肪肝再生過程で増加するATF3は、ネクロ プトーシスの誘導に重要な役割を担うことを明らかにした。

\section{2-1-1＼cjkstart骨芽細胞機能制御におけるIII型ナトリウム/リン 酸共輸送担体の役割}

山崎 美和 ${ }^{1}$ 、川井 正信 ${ }^{1}$ 、大薗 恵一 ${ }^{2}$ 、道上 敏美 ${ }^{1}$

${ }^{1}$ 地方独立行政法人 大阪府立病院機構 大阪母子医療センター 研究所 骨発育 疾患研究部門、 ${ }^{2}$ 大阪大学大学院医学系研究科 小児科学

骨芽細胞や基質小胞の膜上にはIII型ナトリウム/リン酸 $\left(\mathrm{Na}^{+} / \mathrm{Pi}\right)$ 共輸送担体 であるPit-1やPit-2が存在する。本研究においては、骨芽細胞の機能制御に掠 けるこれらの $\mathrm{Na}^{+} / \mathrm{Pi}$ 共輸送担体の役割を明確にするため、マウス骨芽細胞系 細胞株MC3T3-E1 Subclone 4にCRISPR/Cas9を適用し、Pit1 欠損細胞 (Pit1$\mathrm{KO}) 、 \mathrm{Pit} 2$ 欠損細胞(Pit2-KO)を樹立した。いずれの細胞でも $\mathrm{Pi}$ 取り込み能が減 弱していたが、 $3 \mathrm{mM}$ Pi存在下で培養した際の石灰化はむしろ㠵進していた。 このことから、石灰化が細胞外で生じる事象であることが確認された。次に、 石灰化阻害物質であるピロリン酸 (PPi) およびATPの代謝について検討した。 PPiの代謝については、細胞外PPiがPit1-KO、Pit2-KOで上昇しており、7 $\mathrm{mM} \mathrm{Pi}$ 刺激でさらに増加した。細胞内PPiは逆にPit1-KO、Pit2-KOで減少し ており、24時間の $7 \mathrm{mM}$ Pi刺激により全ての細胞で低下した。PPiを細胞外 へ輸送するAnkの発現は $7 \mathrm{mM} \mathrm{Pi}$ 刺激で上昇し、Pi刺激による細胞内PPi 低 下の原因であると考えられた。ATP代謝については、1 mM Pi 存在下の細胞 外ATP量がPit1-KO、Pit2-KOで上昇しており、いずれの細胞でも $7 \mathrm{mM} \mathrm{Pi}$ 刺激でさらに増加した。細胞内 ATP量には細胞間で差を認めなかった。ATP 受容体P2Y2の発現は、Pit1-KO、Pit2-KOで減少していた。以上より、Pit1 Pit2が骨芽細胞に打ける細胞外基質石灰化やPPi - ATPの代謝制御に関わるこ とが示唆された 


\section{2-1-2＼cjkstart副甲状腺ホルモンによる破骨細胞/骨芽細胞カップ リング因子Cthrc1/Waif1 の変化}

永田 友貴、今西 康雄、宮岡 大知、都井 律和、山田 真介、 絵本 正憲、稲葉 雅章

大阪市立大学大学院 医学研究科 代謝内分泌病態内科学

副甲状腺ホルモン (PTH) は骨・腎臟に作用し、血中カルシウムの恒常性を維持 している。また、骨組織においては骨形成㧍上び骨吸収を促進し、骨代謝回転 を立進させる。骨りモデリングは、破骨細胞による骨吸収の後に、骨芽細胞 によって新たな骨が再度形成されるという、破骨細胞/骨芽紐胞カップリング の平衡状態が保持されている。近年様々な破骨細胞/骨芽細胞カップリング因 子が発見されており、破骨細胞が分泌するCthrc1およ゙骨芽細胞に発現する Waif1 はカップリング因子のひとつとして近年報告されたが、PTHによる骨代 謝元進に随伴して起きる、これらの因子の変化は現在のところ梌討されていな い。【目的】 PTHによる骨代謝回転光進とCthrc1/Waif1発現変化の検討【結 果】 PTH持続投与マウス骨組織・抽出液でCthrc1及びWaif1 発現はWTマウ スと比較し増加した。PTH添加し培養した初代培養の骨芽細胞拉よび骨芽細 胞様株UMR-106ではWaif1 増加を認めた。抗RANKL抗体を投与したWTマ ウ又骨形熊計眼で Oc.S/BS、NOc/BS、ES/BSは有意に低下し、同マウス骨抽 出液の Cthrc1発現も有意に低下した。WTマウスへのRANKL投与では骨組 織Cthrc1発現の増加が認められた。【考察】PTHは破骨細胞を直接刺激しな い。PTHによって骨芽細胞が増殖・分化することで破骨細胞分化誘導因子で あるRANKL発現が増加し、破骨細胞が増加抢よび分化するに伴って Cthrc1 が増加すると考えられた【結諭】 PTHに上って骨代謝回転が方准した状能で は、破骨細胞由来のCthrc1発現は増加し、骨芽細胞由来の Waifl も増加する。 骨芽緗胞由来の Waif1 はPTHによって増加し、破骨緗胞由来Cthrc1発現は骨 吸収状態と並行して增減する。

\section{2-1-4 BrosumabによるX染色体遺伝性低リン血症性く る病の治療効果の検討}

原田 大輔 ${ }^{1}$ 柏木 博子 ${ }^{1} 、$ 上山 薰 ${ }^{1}$ 折山 恭子 ${ }^{1}$ 、難波 範行 $^{2}$ 、 清野 佳紀 ${ }^{1}$

地域医療機能推進機構（JCHO）大阪病院 小児科、 ${ }^{2}$ 鳥取大学医学部周産期 小児医学分野

【背景】X染色体遺伝性低リン血症性くる病（XLH）は、リンの腎排泄を允 進させるFGF23の過㮃分泌が原因とされる。2019年に抗FGF23抗体である BrosumabがXLHに対する治療薬として保换承認された。

目的】小児XLH患者におけるBrosumab治療の効果を検討する。

【方法】対象は当院でBrosumabを投与している小児XLH 7名。活性型ビ夕 今ンと中性リン製郕に上る従来治療加ら Brosumab 治療に変更前後 2 年間 に行なった生化学的検查抢よび骨単純X線像の評価（RSS：Rickets Severity Score) の推移を後方視的に比較検討した。

【結果】平均値を比較したところ (従来治療 v.s. Brosumab治療)、Burosumab 治療でRSS $(6.1 \pm 2.7$ v.s. $3.3 \pm 1.5 、 \mathrm{p}<0.01)$ が改善し、\%TRP $(78.4 \pm 9.4 \%$ v.s $91.6 \pm 5.6 \% 、 \mathrm{p}<0.01)$ が上昇した。また、正常範囲内であるが $\mathrm{PTTH}(25.4 \pm$ $11.4 \mathrm{pg} / \mathrm{ml}$ v.s. $58.0 \pm 14.7 \mathrm{pg} / \mathrm{ml} 、 \mathrm{p}<0.01)$ の上昇と尿中 $\mathrm{Ca} / \mathrm{Cre}$ 比 $(0.339 \pm$ 0.202 v.s. $0.083 \pm 0.122 、 \mathrm{p}<0.01 ）$ の低下を認めた。血清中の $\mathrm{P} 、 \mathrm{Ca}$ は両治療法 で有意差がなかった。

【考察】Burosumab治療は骨のくる病所見を改善させるとともにリンの再吸 収率が改善した。これはFGF23が抑制された結果と考えられ、抗体治療を行 う上で病勢コントロールの指標となり得る。また、Burosumab 治療は高Ca尿 症を改善し、従来治療中に起きる腎石灰化を抑制できる可能性が期待される さらに、Burosumab治療中に $\mathrm{PTTH}$ が上昇した機序は不明であるが、XLHの 高FGF23 血症によるPTH 産生抑制をBurosumabが解除した可能性も考えら

【結論】Brosumab治療はXLHに扔いてFGF23の抑制を介して、骨所見および 血液中・尿中の電解質異常を改善し、根本治療として有用である。

\section{2-1-6 X染色体連鎖性低リン血症性くる病成人患者にお ける勒帯 / 腱・関節・歯科・腎合併症に関する検討}

加藤 創生、古家 美菜絵、伊東 伸朗

東京大学医学部附属病院 腎臓内分泌内科

【背景】X染色体連鎖性低リン血症性くる病 $(X L H)$ はPHEX遺伝子異常を原因 とする遺伝性疾患で、FGF23過剩産生による低リン血症によってくる病をき たす。一方で、成人期における勒帯/腱・関節の合併症に関してはその発症 機序や頻度など不明な点が多い。【方法】当院当科に通院中の成人XLH患者 に打ける勒带骨化症、腱付着部症、変形性関節症、歯科合併症、腎石灰化) の頻度㧍上び重症度について後方視的に解析した。【結果】対象任男性11名 女性 12 名、平均年齢は39.7歳(18-72歳)。87\%(23名中 20 名)で勒带骨化症(前 縱勒带骨化症(OALL)、後綎勒带骨化症(OPLL)、黄色勒带骨化症(OFL) ) 認 め、OA index、OP index、OF index、OS indexはそれぞれ3.6 (0-11)、1.5(012)、1.8(0-20)、7.2(0-28)であった。腱付着部症は73\%(23名中 17 例) で、変形

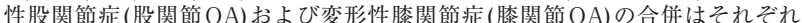
$100 \%(23$ 名中 23 名)、 $87 \%(23$ 名中 20 名)であった。歯科受診した 12 人の歯残在 数は25.2(15-32)本で、うち無治療桠残存数は13.3(0-32)本であった。腎石灰化 は70\%(20例中 14 例)で認めた。【考察】XLHにおける勒带/腱・関節合併症の 頻度は一般人口に扔ける頻度と比較して高頻度で、より重症である。XLH未 診断の OPLL・OFL症例が多く存在している可能性がある。XLHが成人期に なり多彩な䩗鱼/腱・関節・㹂合併症を起こしうることを念頭においた小児 成人期の綿密なフォローアップが必要と考えられる。また、本邦でも使用可能 となったFGF23抗体：ブロスマブのこのような合併症の抑制効果に関しても データの集積が求められる。

\section{2-1-3 レトロトランスポゾン挿入により偽性副甲状腺機 能低下症を発症した 1 家系}

鏡 雅代 ${ }^{1}$ 、湯野 暁子 ${ }^{2}$ 、佐野 伸一朗 ${ }^{1,3}$ 、中村 明枝 ${ }^{1,4}$ 、川嶋 明香 ${ }^{1} 、$ 松原 圭子 ${ }^{1}$ 、細道 一善 ${ }^{5}$ 、哚見 真紀 ${ }^{1}$ 、白井 健 ${ }^{6}$ 、才津 浩智 ${ }^{3}$ 、 緒方 勤 $^{3}$

${ }^{1}$ 国立成育医療研究センター研究所分子内分泌研究部、2 勤医協中央病院内 科、 ${ }^{3}$ 浜松医科大学、 ${ }^{4}$ 北海道大学医学部小児科、 ${ }^{5}$ 金沢大学医薬保健研究域 医学系 革新ゲノム情報学分野、6 静岡県立総合病院遺伝診療科

【背景】偽性副甲状腺機能低下症 (PHP) はGs $\alpha$ の発現異常による PTH不応 性による。Gs $\alpha$ が含まれるGNAS 領域は複数のインプリント遺伝子が存在し、 Gs $\alpha$ は尿細管など一部組織で母性発現する。【目的】レトロトランスポゾン挿 入により発症した家族性 PHPの解析から、遺伝子発現制御機構を解明する。 【方法と結果】母 (死亡)、兄、妹がPHPと診断されていた。兄と妹はGNAS A/B-DMR の軽度低メチル化、XLAS-, AS-, NESP55-DMRの正常メチル化 を示した。全ゲノムシーケンスによりGNAS A/B-DMRの上流にSVA型レ トロトランスポゾンの挿入を同定した。患者皮膚繊維芽細胞でのRNAseqは、 GNAS A/Bの発現増加を認めたが、NESP55, XLAS, ASについては低発現て 評価不能であった。異常 transcriptsも同定されなかった。GNAS領域全体の target Methyl-Seqでは、GNAS A/B-DMR の軽度低メチル化を認めるのみ で、レトロトランスポゾン挿入領域周辺のメチル化変化は認めなかった。【考 察】GNAS領域の遺伝子発現制御機構は不明な点が多い。STX16、NESP55の 母アレル欠失家系でGNAS A/B-DMRの低メチル化が報告されている。本症 例では、NESP55とGNAS A/B-DMR 間のレトロトランスポゾン挿入が周辺 領域のメチル化異常を引き起こし GNAS A/B-DMRの異常メチル化を引き起 こしたということは否定された。レトロトランスポゾン㨂入によるGNAS A B-DMR と転写因子などの結合阻害もしくはcisに作用する transcriptsの発現 異常が予想され、さらなる検討が必要である。

\section{2-1-5 蛍光ナノ粒子 (PID) 染色標本による組織での FGF23 産生定量法の開発}

古家 美菜絵 ${ }^{1}$ 、加藤 創生 ${ }^{1} 、$ 二谷 悦子 ${ }^{2}$ 、小林 寛 $^{3} 、$ 田中 健之 ${ }^{3} 、$ 牧瀬 尚大 ${ }^{4}$ 、牛久 哲男 ${ }^{4}$ 、伊東 伸朗

東京大学医学部附属病院 㹂臟・内分泌内科、2 コニカミノル夕株式会社、 東京大学医学部附属病院 整形外科、 ${ }^{4}$ 東京大学医学系研究科人体病理学. 病理診断学分野

【緒言】腫瘍性骨軟化症(TIO) は骨や軟部組織などに生じた FGF23 産生腫瘍に より、低リン血症性骨軟化症を惹起する疾患である。腫瘍の局在診断はしばし ば困難であり、当院では 43 例中 7 例で腫瘍が未同定である。

TIOでは腫瘍のFGF23産生が六進する一方で正常骨組織のFGF23产生は抑 制される。従って臣床的にTIO と診断されるも腫瘍が未同定である症例の骨 組織に抢けるFGF23産生の抑制の有無により、その症例が FGF23産生腫瘍を 有するか推測することが可能となる。しかし従来の免疫染色ではFGF23の産 生抑制を確認し得る感度は得られなかった。PID (Phosphor Integrated Dot nanoparticles) 技術は標的蛋白質の発現をより高感度に検出し、さらに粒子数 として定量的に評価できる。そこで我々はPIDを用いたFGF23免疫染色標本で FGF23の産生量を検討した。

【方法】当院整形外科で人工股関節置換術を施行された腎機能正常症例 (STD 群)13例、透析症例(HD 群)2例、TIO で腫瘍摘出術を施行された症例の正常骨 組織(TIO群)2例を対象とした。各病理検体についてPIDによるFGF23免疫染 色を行い、細胞核から $5.5 \mu \mathrm{m}$ 以内に存在するPID粒子数を計測した (帰属法)。 【結果】帰属法による1細胞核毎のPID 粒子数の平均值はSTD群 153.7、HD群 357.7、TIO群 19.0であり、STD群と TIO群に有意な差を認めた $(\mathrm{P}<0.001)$ 。 【考察】STD群と比較し TIO 症例の正常骨組織ではPID粒子数が有意に低值で あり FGF23 産生の抑制が確認できた。本手法により原因腫瘍が未同定である 症例の骨生検組織の FGF23 産生量から、本来の病因を推測することが可能とな

\section{2-1-7 1 1型糖尿病ではインスリン分泌能が骨密度に影響 を与える}

鈴木 正睴 ${ }^{1}$ 、浦井 伸 ${ }^{1}$ 、福岡 秀規 ${ }^{1}$ 、廣田 勇士 ${ }^{1}$ 、山本 雅昭 $^{1} 、$ 岡田 裕子 ${ }^{1}$ 、井口 元三 ${ }^{2}$ 、小川 涉 ${ }^{3}$ 、高橋 裕

1 神戸大学医学部附属病院 糖尿病・内分泌内科、 ${ }^{2}$ 神戸大学保健管理七ン 夕一・医学研究科病態情報学、 3 神戸大学大学院医学研究科 糖尿病 - 内分泌 内科学

【背景】1型糖尿病(T1DM)では骨密度(BMD)の低下を認め, 要因の一つに内 因性インスリン不足が考えられているが T1DMにおけるBMD低下の病態や 発症様式との関連は不明である。【目的】 T1DMを劇症 $(\mathrm{F})$, 急性発症 $(A)$, 緩 徐進行 (SP) に分類し, BMD 低下の病態を明らかにする。【方法】単施設後向 き横断研究. T1DM患者を F ; 12例, A ; 51例, SP ; 37例の三群に層別化 し, 腰椎と大腿骨頚部のBMD Z-scoreを検討した、【結果】F群，A群，SP 群のLS Z-score(以下 LS) はそれぞれ-0.35 $\pm 1.01 ，-0.25 \pm 0.96 ， 0.38 \pm 1.08 \mathrm{SD}$, FN Z-score(以下FN)はそれぞれ-0.56 $00.70,-0.44 \pm 1.00,0.03 \pm 1.01$ SDであ り，LS，FNともにF，A群に抢いてSP群より低下傾向を認め, LSはSP群と 比してA群で有意に低值であった $(p=0.02)$. 全体の単相関分析でLSは発症年 齢，食後(pp)CPR，IGF-I SDS と正，TDD/kg と負，FNはBMI，グルカゴン 負荷試験頂值 (GST)CPR と正，TDD $/ \mathrm{kg}$ と負の相関を認めた。重回帰分析で は、ISは有意な関連因子を喼めず，FNはBMI と正の関連を認めた $(\beta=0.38$, $p<0.01)$. 次に A 群とSP群で䍜病期間を 5 年毎に層別化し検討した。内因性 インスリン分泌と BMDについてSP群はA 群と比べ, GST CPRが1-9年で, $\mathrm{BMD}$ は5-14年で有意に高值であったが、その後それぞれ低下傾向を認め, 差 を認めなかった．以上からSP群では内因性インスリン分泌枯渴に伴い BMD 低下が起こっていることが示唆された。【考察】本検討でT1DMでは発症様式 によるBMD低下への影響が異なることが初めて明らかになり，内因性インス リン分泌枯渇とともにBMD低下が生じる可能性が示唆された。 


\section{2-1-8 肥満外科治療前後における天然型ビヌミンD補充 量に関する検討}

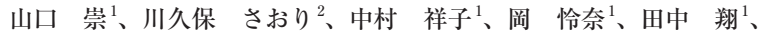
渡邊康弘 ${ }^{1}$ 、河越 尚幸 ${ }^{1}$ 、川名 秀俊 1 、大平 征宏 ${ }^{1}$ 、齋木 厚人 1 、

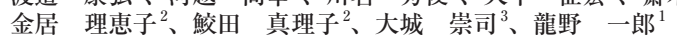

${ }^{1}$ 東邦大学医療センター佐倉病院 糖尿病内分泌代謝セン夕ー、 ${ }^{2}$ 東邦大学医 療センター佐倉病院 栄養部、淔東邦大学医療センター佐倉病院 外科

【目的】ビタミン $\mathrm{D}(\mathrm{VD})$ 欠乏 $(25(\mathrm{OH}) \mathrm{D}<20 \mathrm{ng} / \mathrm{mL})$ を呈するの日本人高度肥 満患者に対する天然型 VD補充が血中 $25(\mathrm{OH}) \mathrm{D}$ 濃度に及ほす影響を明らかに すること。【方法】対象は任意時点の検査でVD欠乏と診断した高度肥満( 往含む)患者 31 例 (内科治療 (LM) 群6 例 (平均BMI37.9)、スリーブ術後(LSG) 群 19 例 (平均 BMI38.5, 術後 $32 \mathrm{Mo}$ )、バイパス術後 (BP) 群6 例 (平均BMI31.4 術後 $40 \mathrm{Mo})) 。$ 天然型 VDサプリの掑取を指導し平均 3.5Mo補充後の血中 $25(\mathrm{OH}) \mathrm{D}$ レ ベルを調查した。【結果】指導後のVD摃取量はLM群 48.8, LSG 群51.3, BP 群 $51.2 \mu \mathrm{g} /$ 日。全例解析で補充前 $25(\mathrm{OH}) \mathrm{D}$ レベルはBMI と逆相関 $(\mathrm{r}=-0.363)$ 、野 外活動時間と正相関 $(\mathrm{r}=0.405)$ を認めた。補充後 $25(\mathrm{OH}) \mathrm{D}$ は全例上昇し、LM 群 5/6例、LSG 群 $13 / 19$ 例、BP群 5/6例が 25(OH)D $220 \mathrm{ng} / \mathrm{mL}$ に到達したが、 $30 \mathrm{ng} / \mathrm{mL}$ 一到達したのは全群 $15 \%$ 程度にとどまった。25(OH)D 変化量はVD 摂取量、補充期間と関連を認めず、LM群+10.8、LSG 群+11.0、BP 群 +8.1ng/ $\mathrm{mL}$ と $\mathrm{BP}$ 群で小さい傾向を認めた。【結論】VD久乏の日本人高度症肥満患者 に対する $50 \mu \mathrm{g} /$ 日の天然型 VD補充は肥満外科治療の有無をとわず $25(\mathrm{OH}) \mathrm{D}$ レベル上昇に有効であるが、不足域を脱するには不十分である。

\section{2-3-1 膵 $\beta$ 細胞脱分化は 2 型糖尿病の病態進展に関連する}

田部 勝也 ${ }^{1}$ 、椎木 幾久子 ${ }^{2}$ 、幡中 雅行 $^{1}$ 、谷澤 幸生 $^{1}$ ${ }^{1}$ 山口大学大学院医学系研究科病態制御内科学、 ${ }^{2}$ 山口大学医学部分子代謝制 御学

近年、糖尿病と膵島細胞の可塑性に注目が集まっている。我々は、Wolfram 症 候群では $\beta$ 細胞脱分化が糖尿病の成因であることを明らかにしてきた。本研 究では、 2 型糖尿病 (T2D) の $\beta$ 細胞の病理と $\beta$ 細胞脱分化の関連について病 能進展の中で解明することを目的とした【方法】膵癌を含む膵胆道疾患によ り外科切除された膵組織標本を用いた。患者; 糖尿病の家族歴がなく全経過で 過体重を認め年齢、手術対象疾患をマッチさせた正常耐糖能患者（対照群）と T2D 患者を対象とし、T2D 群を罪病期間 (5 年以下 vs. 10 年以上)、糖尿病合 併症（無 vs. 細小血管障害を一つ以上有する)、インスリンおよびSU薬（無 vs. 1 年以上の薬剂使用) より早期群と進展群に分類した。組織解析 ; 主要膵 ホルモン (INS、GCG、SMS、PP)、クロモグラニンA(ChgA)に対する抗体を用 い免疫組織染色を行った。膵面積に対するINS陽性面積比 ( $\beta$ ) およびGCG 陽性面積比 $(a)$ を計測し、膵島量としてChgA陽性面積比を計測した。膵島 内 ChgA 陽性細胞に対する INS 陽性（ $\beta$ i ）、GCG 陽性細胞数比（ $\alpha$ i ）を計測 した。主要膵ホルモン陰性ChgA陽性細胞を脱分化細胞とし、ChgA 陽性細胞 に対する細胞数比を計湘した。【結果】T2Dの膵島量、 $\beta$ および $\alpha$ は多様であ り代謝病態の多様性が推察された。T2D膵島では $\beta$ i 低下、 $\alpha$ i増加、 $\alpha \mathrm{i} / \beta \mathrm{i}$ 増加とともに脱分化細胞が顕著に増加した。さらに進展群では早期群に比し脱 分化細胞が有意に増加し、脱分化細胞量は 3 群間で進行性に低下するCPI と有 意な逆相関を示した。【結論】 T2Dにおける膵島細胞の可塑性と $\beta$ 細胞の病態 進展における脱分化の重要性が示唆された。

\section{2-3-3 1 型糖尿病の残存膵 $\beta$ 細胞ではHIF1 $\alpha /$ PFKFB3 経 路が活性化し解糖系がえ進する}

野本 博司 ${ }^{1}$ 、Slavica Tudzarova ${ }^{2}$ 、Lina Pei ${ }^{2} 、$ Chiara Montemurro ${ }^{2}$ 、 Tatyana Gurlo 、Peter C Butler ${ }^{2}$ 、中村 昭伸 ${ }^{1}$ 、渥美 達也 ${ }^{1}$ ${ }^{1}$ 北海道大学大学院医学院医学研究院 免疫 ·代謝内科学教室、 ${ }^{2}$ Larry L Hillblom Islet Research Center, University of California, Los Angeles

【背景と目的】1型糖尿病(T1D)では膵 $\beta$ 細胞の破壊に伴う減少を生じるが、発 症後早期には膵 $\beta$ 細胞量は比較的保たれることが知られている。このような減 少・破壊過程の膵 $\beta$ 細胞において、膵島内代謝にどのような変化が生じている かを知ることは病態を理解するうえで重要である。近年われわれはヒト型islet amyloid polypeptideを発現した糖尿病モデル動物や 2 型糖尿病 (T2D) 患者膵島 において、HIF1 $\alpha /$ PFKFB3 経路が活性化することで膵 $\beta$ 細胞の細胞内代謝が 解糖系にシフトしていることを報告した。そこで今回われわれはT1D患者剖 検膵ならびに非糖尿病単離膵島へのサイトカイン負荷モデルを用いて、これら の状態下に抢ける膵 $\beta$ 細胞の HIF1 $\alpha / \mathrm{PFKFB} 3$ 経路活性化の有無について検討 した。

【結果】T1D膝島のRNA-Seqでは、PFKFB3を含むHIF1 $a$ の標的遺伝子な らびに解糖系酵素群の遺伝子発現の上昇を認めた。T1D患者剖検膵では、残 存膵 $\beta$ 細胞に扔けるPFKFB3の染色強度・陽性細胞比が非糖尿病患者と比し 有意に六進していた。さらにミトコンドリア染色では膵 $\beta$ 細胞内ミトコンド リアの断片化と密度の減少を認めた。単離膵島へのサイトカイン刺激により、 PFKFB3などの解糖系酵素の㠵進に伴い乳酸産生の上昇が認められた。 【結語】T1D膵島や膵島へのサイトカイン頁荷モデルにおいて、膵 $\beta$ 細胞にお ける HIF1 $\alpha$ /PFKFB3 経路が活性化し、TCAサイクルから解糖系への代謝リ モデリングをきたしていることが明らかとなった。

\section{2-1-9 副甲状腺に対する赤外線カメラを用いた蛍光につ いての検討}

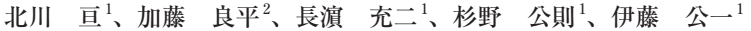
${ }^{1}$ 伊藤病院 外科、 ${ }^{2}$ 伊藤病院 病理診断科

【目的】近年、甲状腺・副甲状腺手術に抢いて術中赤外線をあてることで、副 甲状腺が内因性に蛍光し術中の補助診断に用いることが報告されている。し かし、内因性に蛍光する機序は明らかになっていない。今回、蛍光の強い副 甲状腺と弱い副甲状腺について検討を加えた。【対象と方法】2018年1月か ら8月まで原発性副甲状腺機能立進症で手術した45例中、パラフィンブロッ クの蛍光が 150 以上あった 10 例 (High 群、以後 $\mathrm{H}$ 群) と蛍光が 80 以下の 8 例 (Low 群、以後L 群)。年齢中央值と性別はH 群68歳（54-78）女性 10例、L 群 53歳（26-70）男性 1例、女性 7例。撮像は赤外線カメラ (pde-neo：浜松ホ卜 ニクス社）を使用し、パラフィンブロックから $15 \mathrm{~cm}$ の距離から同一条件（明 るさ-1.0、コントラスト 4.0、励起光5.0) で行った。撮像画面から浜松ホト ニクス社製輝度解析ソフトROIsを使用し、蛍光の強さを解析した。H群、L 群それぞれのPTH-I值、血清カルシウム值、最大径、重量、病理組織（主細 胞、明細胞、好酸性細胞の比率) を比較検討した。【結果】蛍光值は $\mathrm{H}$ 群 174 (154-255)（中央值、range）、L群63.5（51-80）であったPTH-I值、血清力 ルシウム值、最大径、重量はそれぞれ、H群 $153.5 \mathrm{pg} / \mathrm{ml}$ （75.3-352)、11.6 $\mathrm{mg} / \mathrm{dL}(10.4-12.7) 、 20 \mathrm{~mm}(11-32) 、 580 \mathrm{mg}(133-3010) 、 \mathrm{~L}$ 群 $120.5 \mathrm{pg} / \mathrm{ml}$ $(73.2-354) 、 11.0 \mathrm{mg} / \mathrm{mL}(10.0-11.8) 、 13 \mathrm{~mm}(9-22) 、 380 \mathrm{mg}(19-2240)$ で 有意差はなかった。病理組織の主細胞、明細胞、好酸性細胞の比率は、H群、 $30 \%(0-100) 、 2.5 \%(0-70) 、 55 \%(0-100) 、$ L 群 $99 \%(0-100) 、 0 \%(0-$ 100)、0\% (0-2) で好酸性細胞の比率が L 群に比べ、有意にH群で高かった。 【まとめ】副甲状腺の内因性の赤外線蛍光に好酸性細胞が関連している可能性 が示唆された。

\section{2-3-2 糖尿病関連遺伝子UBE2E2の膵 $\beta$ 細胞における役割}

桜井 賛孝 ${ }^{1}$ 、窪田 直人 ${ }^{1,2,3}$ 、高本 偉碩 ${ }^{4}$ 、和田 亘弘 ${ }^{3}$ 、林 高則 ${ }^{3} 、$ 窪田 哲也 ${ }^{3}$ 、䈎子 敬洋 ${ }^{1}$ 、門脇 孝 $^{1}$ 、山内 敏正 ${ }^{1}$

${ }^{1}$ 東京大学大学院医学系研究科 糖尿病 - 代謝内科、 ${ }^{2}$ 東京大学医学部附属病 院 病態栄養治療部、 ${ }^{3}$ 医薬基盤・健康 · 栄養研究所 臨床栄養研究部、 ${ }^{4}$ 練馬 光が丘病院 糖尿病内分泌内科

【背景と目的】GWASに上り東アジア人に特徵的な 2 型糖尿病関連遺伝子とし てユビキチン修飾系関連分子であるUBE2E2が報告されているが,その機序は 不明である.そこで膵 $\beta$ 細胞特異的UBE2E2 トランスジェニック (TG) マウスを 作製し表現型を解析した.【方法】マウス膵島の mRNA由来のcDNAをもとに UBE2E2蛋白をコードする exon2-6の領域をクローニングし,RIP プロモーター 下に配置したコンストラクトを構築し作製した。結果】独立した 2 ラインの TGマウスの膵島に扔けるUBE2E2 は蛋白レベルで十分に過剩発現されており 過剩発現は膵 $\beta$ 細胞に特異的であった.また,摄慨量,体重,随時血糖,インスリ ン感受性のいずれも対照群と同等であったが,経口/経腹腔的糖負荷試験のい ずれにおいてもインスリン分泌低下を伴う高血糖を呈し,膵組織像では $\beta$ 細胞 量の減少を認めた.同様の所見は若週齢でも認め,高脂肪食負荷ではより顕在化 した一方，単離膵島のインスリン遺伝子発現やグルコース応答性インスリン分 泌は対称群と同等であった.プロテオーム解析の結果,TGマウスの膵島では膵 癌等で高発現している Mesothelin(MSLN)の著明な低下を認め,この発現低下は mRNAレベルでも認めた.MSLN遺伝子は他の組織に比較して膵島で高発現で あった.また,MSLNの免疫組織染色では,アダルト期よりも生後 1-2 週齢で著明 な発現増加を認めたが,同時期においても TGマウスの膵島のMSLNの発現は 低かった。【結論】膵 $\beta$ 細胞のUBE2E2の過剩発現は膵 $\beta$ 細胞量の低下を介し てin vivoに扔ける糖負荷後のインスリン分泌低下に関与していることが示唆 された

\section{2-3-4 腸管NAMPT-NAD+合成系はインクレチン合成 を調節し、糖代謝障害発症を制御する}

永久 太年、山口 慎太郎 ${ }^{1}$ 、小杉 将太郎 ${ }^{1} 、$ 宇都 飛鳥 ${ }^{1} 、$ 宮下 和季 ${ }^{1}$ 、吉野 純 $^{2}$ 、入江 潤一郎 ${ }^{1}$ 、伊藤 裕 ${ }^{1}$ 慶應義塾大学 医学部 腎臟内分泌代謝内科、 ${ }^{2}$ ワシントン大学医学部 内科

【目的】哺乳類 NAD + 合成系の鍵醅素であるNAMPTは環境・栄養状態に応 答することでNAD + 量を調節し、生物学的な多彩な局面で重要な役割を果な す。我々は脂肪組織の NAMPT-NAD+合成系が、インスリン抵抗性やエネル ギー代謝を制御することを報告している (Yamaguchi et al. PNAS 2019)。さら に近年、高脂肪食に伴う腸管炎症がインスリン抵抗性発症過程で最も早期の変 化であることを見出した。本研究では腸管NAMPT-NAD+合成系の糖代謝制 御に打ける役割を検討する。【結果・考察】C57/BL6マウスに高脂肪食を負荷 し、腸管Namptの経時的変化を qRT-PCRで検証した。高脂肪食 4 週では、通 常食に比し、小腸Nampt及び随時血糖に有意差を認めなかった。一方、高脂 肪食8 週では、小腸 Nampt は有意に低下し、随時血糖は上昇傾向 (通常食 vs 高脂肪食: $195.6 \pm 17.2$ vs $247.8 \pm 21.6 \mathrm{mg} / \mathrm{dl}, \mathrm{p}=0.09$ )を示した。そこで、高脂 肪食に伴う腸管Nampt低下の糖代謝における意義を検討するため、腸管特異 的Namptノックアウトマウス $(\mathrm{KO})$ を作成した。KOマウスでは、controlマウ スと比し、摄餌量・体重に差を認めなかった。また、腹胿内糖負荷試験では、 2群間で有意な差を認めない一方、経口糖負荷試験では KO 群で血糖曲線下面 積の有意な増悪 (control vs KO: $31460.8 \pm 796.8$ vs $36615.7 \pm 976.1 \mathrm{mg} / \mathrm{dl} * \mathrm{~min}$, $\mathrm{p}<0.01)$ を呈した。またKOマウスでは、インクレチン合成に関与する回腸 Proglucagonの低下 (control vs KO: $1.0 \pm 0.16$ vs $0.46 \pm 0.13, \mathrm{p}=0.02$ ) を認めた。 以上より、腸管NAMPT-NAD+合成系がインクレチン合成を調節し、全身の 糖代謝を制御する可能性が示唆された。 


\section{2-3-5 ABCD1 欠損によるペルオキシソーム機能障害が 肥満病龍に及ぼす影響}

和田 努 ${ }^{1}$ 、渡邊 愛理 ${ }^{1}$ 長谷川 堸 ${ }^{1}$ 渡辺 志朗 ${ }^{2}$ 、守田 雅志 ${ }^{3} 、$ 恒枝 宏史 ${ }^{1}$ 、笹岡 利安 $^{1}$

${ }^{1}$ 富山大学 病態制御薬理学、 ${ }^{2}$ 富山大学 和漢医薬学総合研究所 栄養代謝学分 野、3 富山大学 分子細胞機能学

【目的・方法】ペルオキシソームは栄養状態の変化に迅速に対応してその $\beta$ 酸 化能を向上させ、脂質代謝の恒常性維持に寄与する細胞内オルガネラである。 極長鎖脂肪酸輸送体ATP Binding Cassette Protein Subfamily D 1 (ABCD1) はペルオキシソームにのみ発現し、その機能に重要であるが、その久損による ペルオキシソーム機能低下が肥满病態に及ぼす影響は未知である。そこで本研 究では、 $\mathrm{ABCD} 1$ 欠損マウス $(\mathrm{KO})$ と野生型マウス(WT)に通常食または高脂肪 食(HFD)を給慨し、エネルギーおよび糖脂質代謝に及ほす影響を検討した。 【成績】HFD負荷によりKOはWTと比較し、体重増加、組織重量変化、工 ネルギー代謝に変化を示さなかったが、糖・インスリン頁荷試験の顕著 な増悪を呈した。HFD負荷KOとWT間で内瀻脂肪組織の慢性炎症には 変化を認めなかった。一方、 $\mathrm{KO}$ は肝臟の $\mathrm{CD} 45^{\mathrm{N}} \mathrm{F} 4 / 80^{\mathrm{hi}}$ クッパー細胞数 と CD45 ${ }^{+} \mathrm{CD} 11 \mathrm{~b}^{\mathrm{hi}} \mathrm{CD} 11 \mathrm{c}^{+}$浸潤M1マクロファージ数の増加、拈上びIL1bと NLRP3の発現增加を示した。その機序を解明するために肝荿の脂肪酸を解析 した結果、KOではアラキドン酸の有意な増加、拉よびステアリン酸からオレ イン酸への代謝障害が示唆された。さらに、KOマウス由来の骨髄由来マクロ ファージ $(\mathrm{M} \Phi)$ は、 in vitroでLPS刺激に対する有意な炎症反応性の元進を示 したことから、その機序を細胞内代謝の観点から検討している。

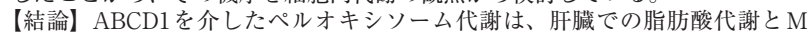
Ф系細胞の炎症活性を調節することで慢性炎症促進を抑制し、糖代謝恒常性維 持に寄与することが明らかとなった。

\section{2-3-7 盰臓におけるHNF4 $\alpha$ を介した糖新生遺伝子の転 写機構の解明}

門間 里奈、宮入 優里、横山 敦、菅原 明

東北大学 大学大学院医学系研究科 分子内分泌学分野

【目的】糖新生経路の六進メカニズムの解明は新規糖尿病治療薬の開発に重要 である。グルカゴンに上る糖新生経路律速醏素の登現にはPGCl $a$ をはじめ とした様々な因子の関与が知られており、核内受容体HNF4 $a$ もその1つであ る。糖新生遺伝子の発現における HNF4 $a$ と PGCl $a$ との相互作用は明らかに なっているが、他の因子の存在は未だ不明である。本研究の目的は、HNF4 a がどのような因子と相互作用し、糖新生遺伝子転写を調節しているのかを解 明することである。【方法】ヒト肝がん細胞HepG2が糖新生を誘道するPKA シグナルに応答するかを確認するために、同細胞を forskolin $25 \mu \mathrm{M}$ で刺激 した後にレポーターアッセイを行った。さらに、糖新生遺伝子 G6PCのプロ モーター上に存在するHNF4 $a$ 結合配列への変異の有無で転写活性に差が出 るかをルシフェラーゼアッセイにより確認した。また、HepG2 とマウスの肝 組織を用いてChIPアッセイを行い, HNF4 $a$ が糖新生遺伝子のプロモーター 上にリクルートされるのかを検討したささらにHepG2やマウスの肝組織を 用いてRIME(Rapid immunoprecipitation mass spectrometry of endogenous proteins)法を行い、HNF4 $a$ が形成する転写複合体の精製・同定を行った。 【成績・結論】G6PCのプロモーター上にある HNF4 $a$ 結合配列に変異を入れる と、野生型のプロモーターと比較してルシフェラーゼ活性が大きく抑制される ことが確認された。またChIPアッセイでは、HepG2、マウス肝組織の両方 でHNF4 aが糖新生遺伝子のプロモータートヘリクルートされている結果が得 られた。これら結果から HNF4 $a$ が糖新生遺伝子の発現に大きく関与している ことが確認できた。現在、HepG2 細胞を用いてRIME法を行った結果得られ たPIN1 という因子に着目して検討を進めている。

\section{2-3-9 盰臓 2型自然免疫細胞の血糖低下作用機序の検 討-RNA-seq/ATAC-seq/GATA3-ChIP-seq/ MASSを用いた統合解析一}

藤本 真德 ${ }^{1}$ 、横山 真隆 ${ }^{2}$ 、姚 躍 ${ }^{2}$ 、横手 幸太郎 ${ }^{1}$ 、田中 知明 ${ }^{2}$ ${ }^{1}$ 千葉大学医学部附属病院 糖尿病 - 代謝 - 内分泌内科、 ${ }^{2}$ 千葉大学医学研究 院 分子病態解析学

【緒言】2型自然リンパ球(ILC2)は近年見出された免疫細胞である。最近では、 IL33により活性化された脂肪組織中のILC2の、血糖改善作用も報告され、そ の作用が注目を集めている。かし他の贜器におけるILC2の機能的役割は殆 ど分かっていない。我々は免疫細胞ILC2が持つ糖代謝機能について、その全 身分布と併せて検討した。【方法と結果】まずILC2 活性化を担う IL-33投与 が、空腹時血糖に与える影響を観察したところ、野生型マウスや成熟 T細胞 を欠損したNudeマウスではIL-33投与により空腹時血糖が有意に低下した そして、ILC2を含む免疫細胞を欠損したNSG (NOD/SCID II2rg(-/-)) マウス では、この血糖低下作用は消失した。IL33刺激後のILC2 は特に肝臟におい てIL13の産生を著明に增加させることがFACSの検討で明らかとなり、NSG マウスに肝㴅ILC2を移植すると有意な血糖低下作用を認めた。この効果は IL13(-/-) 由来の肝臟ILC2移植では消失したため、肝臟ILC2 由来のIL13に着 目した。IL13を初代培養肝細胞へ添加すると、G6pcやPck1などの糖新生醉 素の発現が直接抑制されることがわかった。次に、肝臟ILC2におけるIL13 産生機序を検討するため、肝㖑 ILC2、肺 ILC2、脾臓ILC2、肝臟Th2を用い て、RNA-seq·ChIP-seq $\cdot$ LC-MS/MSの統合解析を行った。その結果、肝 臓ILC2ではIL13のプロモーター領域に転写因子GATA3の強い結合 peak 認 め、さらに由来臓器ごとに他の基本転写因子と転写複合体を形成していること が判明した【結語】肝蔔ILC2の新たな機能的役割として肝糖新生抑制を介し た血糖改善作用を初めて示し、その機序におけるIL33/GATA3/IL13軸の重要 性を明らかにした。
02-3-6 HIF安定化薬は糖尿病によって生じる腎エネルギー 代謝変化を軽減する

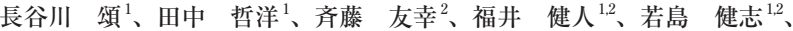
南学 正臣 ${ }^{1}$

東京大学 医学部 腎臓・内分泌内科、 ${ }^{2} \mathrm{JT}$ 医薬総合研究所

【背景】HIF（hypoxia-inducible factor）安定化薬は内因性のエリスロポエチ ン産生を高める次世代の腎性貧血治療である。糖尿病性腎障害（DKD）では、 腎臟が低酸素状態に晒されているのと同時にエネルギー代謝にダイナミック な変化が生じている。一方、HIFは低酸素環境への適応として、酸素を使う TCA 回路から酸素を使わない解糖系へと細胞の代謝をシフトさせることから、 HIF 安定化薬が糖尿病で生じる腎臟内のエネルギー代謝変化に拮抗する働きを するとの仮説を抱き、コンセプトの検証害験を行った。

【方法】8週龄SD ラットを2群に分け、vehicle $(\mathrm{n}=5$; 対照群) および streptozotocin を経静脈投与した。1 週後に streptozotocinを投与したラットか ら DKD群 $(\mathrm{n}=7)$ およびDKD + HIF安定化薬群 $(\mathrm{n}=7)$ を作り、2週後に 㛑皮質のトランスクリプトーム・メタボロームの統合解析を行った

【結果】DKD群の㹂臟では対照群と比較して脂質・アミノ酸代謝に関連する遺 伝子群の発現が充進し、解糖系・TCA 回路の中間代謝物が蓄皘しており、尿 細管が過剩な糖を吸収するためのエネルギー需要を反映していると考えられ た。一方、HIF安定化薬投与は糖尿病とは対称的な代謝変化を引き起こした。 すなわち、糖代謝関連遺伝子群の発現が元進し、解糖系・TCA 回路の中間代 謝物の蓄積が解消され、酸化ストレスを反映する酸化型グルタチオンも低下し たさらにalloxan誘道糖㡾病マウスでも同样の傾向が確認できた。

【結論】 HIF 安定化薬は糖尿病で生じた腎エネルギー代謝変化に拮抗するよう に働き、正常な状態に近つけることが示された。本研究で用いたエネルギー代 謝変化を俯略的に把握する手法は、代謝をターゲットにした治療開発に慗がる 可能性がある

\section{2-3-8 不動化は $\mathrm{Ca}^{2+}$ シグナルの減弱を通じて筋萎縮を制 御する}

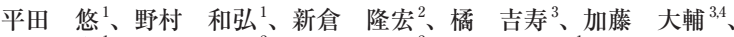
内山 奏、福井 友章 ${ }^{2}$ 大江 啓介 ${ }^{2}$ 、細岡 哲也、和氣 弘明 $^{3.4} 、$ 黑田 良祐 ${ }^{2} 、$ 小川 涉

神戸大学大学院医学研究科 糖尿病 - 内分泌内科学、 ${ }^{2}$ 神戸大学大学院医学 研究科 整形外科学、 ${ }^{3}$ 神戸大学大学院医学研究科 システム生理学、 ${ }^{4}$ 名古屋 大学大学院医学系研究科 分子細胞学分野

【目的】骨格筋はインスリンの主要な作用の場であり、サルコペニアは筋隇少 と身体活動低下の両者を通じ、耐糖能の悪化を引き起こす。また、身体活動の 低下自体が筋量を減少させることも知られているが、そのメカニズムは明らか ではない。本研究では、活動低下・不動化による筋量減少の分子機構について 解析した。【方法と結果】下肢ギプス固定による不動化性筋萎縮モデルマウス の骨格筋では転写因子 KLF15の遺伝子発現が増加し、骨格筋特異的KLF15 久 損マウスでは不動化による筋量減少や萎縮関連遺伝子の発現増加が抑制され た。不動化によるKLF15の発現増強には転写因子 C/EBP $\beta$ および $\delta$ が重要な 機能を担い、培養筋細胞やマウス個体ではCaMKK阻害薬の投与によってC EBP $\mathrm{KLF} 15$ の発現増加など、不動化性筋萎縮時の遺伝子発現変化が模做さ

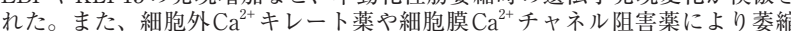
時の遺伝子発現変化が生じたことから、細胞外からの $\mathrm{Ca}^{2+}$ 流入減弱により筋 㫫減少シグナルが活性化されると考えられたギプス固定に上る䈌菱縮患者の 筋生検試料では、KLF15の発現量は C/EBP P筋萎縮関連遺伝子の発現量と強 い正相関を示し、ヒトの筋菜縮に拈いても C/EBP-KLF15による遺伝子転写力 スケードの活性化が重要な役割を担うと考えられた。【結論】不動化では細胞

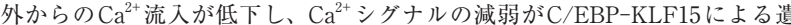
伝子転写カスケードを活性化し、筋萎縮を惹起すると考えられた。

\section{2-4-1 クッシング病下垂体腺腫におけるCYP3A4発現と POMC 発現の関連性}

竹下 章 ${ }^{1}$ 右高 潤子 ${ }^{3}$ 、荻久保 明香 ${ }^{1} 、$ 辰島 啓太 ${ }^{1}$ 、福原 紀章 ${ }^{2} 、$ 岡田 満夫 ${ }^{2}$ 、西岡 宏 2 、井下 尚子 ${ }^{4} 、$ 山田 正三 ${ }^{2.5}$ 、竹内 靖博 ${ }^{1}$ 1 虎の門病院 内分泌代謝科、年虎の門病院 間脳下垂体外科、 ${ }^{3}$ 聖マリアンナ医 科大学 解剖学講座機能組織学、 ${ }^{4}$ 東京都健康長寿医療センター 病理診断学 科、5 森山脳神経センター病院 間脳下垂体センター

【背景】ACTH 產生下垂体腫癔が原因であるクッシング病では、コルチゾール によるACTH分泌の抑制、即ちネガティブフィードバック (NF) 機構が破綻し て扔り ACTHの持続的分泌を生じる。しかしながらクッシシグ病における NF 機構破綻のメカニズムは不明である。

【方法と結果】 ACTH産生下垂体腫瘍から抽出したRNAのうち、ACTHの 前駆体であるPOMC 遺伝子の発現が高い腫瘍 3 例と、低い腫癔3例を選び、 DNA マイクロアレイを用いて両群での遺伝子発現プロファイルを比較した ところ、POMC連伝子の発現が高い腫瘍で、主に胿搭や腸管に登現しコルチ ゾール代謝に関わるCYP3A4遺伝子発現が高かった。このため50例の腫瘍 RNAを用いて定量リアルタイムPCRを行い検証したところPOMC mRNA と CYP3A4 mRNA 発現量に正の相関が認められた。CYP3A4モノクローナル 抗体を用いた免疫染色を 71 例の ACTH 産生下垂体腫瘍で行ったところ、約 $50 \%$ は発現陰性であったが約 $35 \%$ が弱陽性、約15\%が強陽性であった。また POMC mRNA とCYP3A4免疫染色スコア、CYP3A4 mRNA とCYP3A4免疫 染色スコアに正の相関が認められた

【考察】ACTH産生下垂体腫境の約半数にCYP3A4の発現が認められ、 CYP3A4発現が高いほどPOMC発現も高いことから、CYP3A4による腫瘍組 胞内コルチゾール代謝の促進がクッシング病における NF 機構の破綻の成因の ひとつに関与する可能性が示唆された。 


\section{2-4-2＼cjkstart糖質コルチコイドによる正のフィードバック機構 の関与が想定されるクッシング病}

辻本 泰貴 ${ }^{1} 、$ 志智 大城 ${ }^{2}$ 福岡 秀規 ${ }^{3}$ 、中村 友昭 ${ }^{1}$ 神澤 真紀 $、$ 石田 敦士 $、$ 、山田 正三 、小川 涉 ${ }^{2}$ 、高橋 裕 $^{2}$ 、千原 和夫 $^{1}$ ${ }^{1}$ 明石医療センター 糖尿病・内分泌内科、 ${ }^{2}$ 神戸大学大学院医学研究科糖尿 病 - 内分泌科学、 ${ }^{3}$ 神戸大学医学部附属病院糖尿病 - 内分泌内科、 ${ }^{4}$ 同病理 診断科、啝山脳神経センター病院 間脳下垂体センター

【症例】 62 歳女性。満月粎顔貌、中心性肥満、高血圧、低 $K$ 血症、椎体圧迫骨 折を認め、早朝血清コルチゾール (F) $28 \mu \mathrm{g} / \mathrm{dL}$ 、血漿 $\mathrm{ACTH} 299 \mathrm{pg} / \mathrm{mL}$ 、夜間 血清F $43 \mu \mathrm{g} / \mathrm{dL}$ 、蓄尿遊離 $\mathrm{F} 988 \mu \mathrm{g} /$ 日 と高値、CRH刺激試験で血漿 $\mathrm{ACTH}$ の增加反応を示し、下垂体MRIで $14 \mathrm{~mm}$ の腫瘍を認めた。しかし、1 $\mathrm{mg}$ 拉よ び8mgデキサメタゾン(Dex)抑制試験のいずれでも血清 $\mathrm{F}$ は抑制されず、奇異 性の上昇を認めた。糖質コルチコイド (GC)による正のフィードバック (FB) 機 構が作動している可能性を想定し、正の FB機構を遮断する目的でメチラポン $1000 \mathrm{mg}$ / 日の投与を開始したところ、血清 $\mathrm{F}$ と血漿 $\mathrm{ACTH}$ が有意に低下した のみならず、驚いたことに下垂体腫湟の縮小も認められた。下垂体腫韵摘出術 後8日目、血清F7.6 $\mu \mathrm{g} / \mathrm{dL}$ 、血漿 $\mathrm{ACTH} 35.8 \mathrm{pg} / \mathrm{mL}$ まで低下したが、腫瘍の

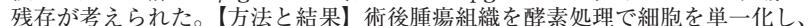
3D培養系でDex0.1-10nM 处理したところ、培地への ACTH 分泌は 0.1、1nM では差がなかったが、10nMの 48、72時間処理でともに 1.3 倍 $(\mathrm{p}<0.05 、 \mathrm{p}<0.01)$ の上昇を認めた。【考察】DexによってACTH分泌が増加した症例は、過去に 5例報告されている。しかし GCによる正の FB機構を想定してメトピロン投与 を行い、ACTH分泌の低下並びに下垂体豚瘍サイズの縮小を観察した報告は 無く世界初である。クッシング病の多椂性、治療戦略を考案する上で示唆に富 む症例である。

\section{2-4-4アフロメガリーに対する手術治療の進歩}

天野 耕作、小田 侑一、川俣 貴一

東京女子医科大学 脳神経外科

【はじめに】アクロメガリー治療の第一選択は経鼻的腫瘍摘出術であり、手術 技術の向上がその治療成績・予後に大きく影響する。手術のみで完治できない 症例に対する複合的治療の進歩も著しいが、その治療妏果をより一層高める ためには、全摘出ができないまでも可及的に腫瘍を摘出することは重要な意 味を持つまた全摘出をなし得た症例でも患者の満足度は必ずしも高いとは 限らず、症例に応じて様々な対応が求められる。腫瘍の摘出率向上を目指し た手術手技の工夫、患者の満足度向上に向けた工夫、その治療成績を報告す る。【対象・方法】 2004 年 12 月から 2018 年 9 月までの間に当科で経鼻的経媒形 骨手術を施行したアクロメガリー自験 133例（年齢10-75歳、平均50.2歳、男 女比 50:83)。これを第一期 $(-2008 / 3: 41$ 例)、第二期 $(-2012 / 5: 45$ 例)、第 三期 $(-2018 / 9: 47$ 例 $)$ に分類し治療成績を比較検討した。第二期以降では海 綿静脈洞 (CS) 内に侵潤した腫瘴を内視鏡斜視鏡下に積極的に摘出を行った。 第三期では更にCS内壁の摘出も積極的に行った。【結果】 Cortina consensus に基づく remission rateは全体： $82.7 \%$ 、第一期 $73.1 \%$ 、第二期 $84.4 \%$ 、第三期 89.4 \%であった。CS浸潤高度な Knosp grade 3-4 症例では第一期 $20 \%$ 、第二期 $33.3 \%$ 、第三期 $69.2 \%$ あ゙った。【考察・結語】アクロメガリーの摘出率が経 時的に向上した理由としては、1.内視鏡下手技の向上、2.内視鏡斜視鏡下操作 に適した器具の開発、3. 積極的なCS内壁・CS内腫瘍の摘出、4. 止血手技の向 上、5.外眼筋モニターの導入、などが考えられた。

\section{2-4-6 GH産生下垂体腫瘍における SDHxの体細胞copy 数減少症例は治療抵抗性を示す}

大和 梓 ${ }^{1}$ 、永野 秀和 ${ }^{1}$ 、山形 一行 ${ }^{1}$ 、橋本 直子 ${ }^{1}$ 、高 躍 ${ }^{1,2}$ 、 岩立 康男 ${ }^{2}$ 、福世 真樹 $^{3}$ 、金田 篤志 ${ }^{3}$ 、井下 尚子 $^{4}$ 、福原 紀章 5 、 西岡 宏 ${ }^{5}$, 山田 正三 6 、田中 知明 ${ }^{1}$

${ }^{1}$ 千葉大学大学院 医学研究院 分子病態解析学、 ${ }^{2}$ 千葉大学病院脳神経外科、 ${ }^{3}$ 千葉大学大学院 医学研究院 分子腫瘍学、 ${ }^{4}$ 東京都健康長寿医療センター 病 理診断科、 ${ }^{5}$ 虎の門病院 間脳下垂体外科、 ${ }^{6}$ 東京脳神経センター病院

【背景】GH産生下垂体腫瘍(GHoma)の30 50\%でGNAS体細胞変異を認め る.GNAS変異例は腫癔が小さく薬物治療の効果が良好である傾向がある一方, 治療抵抗性を示す症例の遺伝的背景は充分に解明されていない.【目的・方 法】対象は千葉大学拉よび虎の門病院で手術を施行されたGHoma106 例. NGS を用いたターゲットシークエンスで 36 遺伝子の変異解析ならびに対象遺伝子 の copy 数解析を行い, 臨床的特徎 - 遗伝子発理解析・病理学的特性との関連 を検討した。【結果】遺伝子変異解析では 29 遺伝子に 78 変異を認め 1 症例あた りの変異遺伝子数の中央值は 3.0 (範囲0.0-9.0) であった.GNAS変異は5 59 症例 (55.7％)に認めた.GNAS以外に genotype-phenotype 相関は認めなかった.Copy 数解析では 2 症例にcopy 数増加, 6 症例にcopy 数減少を認めた.Copy 数減少 を認めた全症例でSDHx の copy 数隇少を有し,これらの症例は有意に腫癔体皘 が大きく $(\mathrm{p}=0.014)$. Knosp grade高值だった $(\mathrm{p}=0.016)$. またりマトスタチンア ナログの投与による腫愓体積減少率が有意に低く $(\mathrm{p}=0.002)$, 術後治療を要し た症例の割合が有意に多かった $(\mathrm{p}<0.05)$. SSTR2 遺伝子発現は有意に低かった $(\mathrm{p}=0.023)$.【結論】 $\mathrm{SDHx}$ の体細胞 copy 数解析はGHomaの新たな治療予後予測 因子となる可能性がある。

\section{2-4-3 クッシング病に対する静脈洞サンプリングの診断 成績と問題点}

福原 紀章 $1,2,3$ 井下 尚子 ${ }^{1,2,3,4}$ 、福原 宏和 ${ }^{1}$ 岡田 満夫 ${ }^{1} 、$ 辰島 啓太 ${ }^{5}$ 、竹下 章 ${ }^{3,5}$ 、伊藤 純子 ${ }^{6}$ 、竹内 靖博 ${ }^{3,5}$ 、西岡 宏 ${ }^{1,3}$ ${ }^{1}$ 虎の門病院 間脳下垂体外科、 ${ }^{2}$ 東京医科歯科大学 大学院医歯学総合研究科 包括病理学分野、 ${ }^{3}$ 沖中成人病研究所、 ${ }^{4}$ 東京都健康長寿医療センター 病理 診断科、 ${ }^{5}$ 虎の門病院 内分泌代謝科、 ${ }^{6}$ 虎の門病院 小児科

【序論】かつてはクッシング病（CD）診断に抢ける静脈洞サンプリング（VS） は診断のゴールドスタンダードとされていた。しかし、近年MRIの発達によ り微小腺腫の診断成績が向上し、VSの必要性が少なくなっている。今回、当 院でのVSの成績を検討した。【方法】VSを受けたCD53例を対象とした。う ち31例はMRIで下垂体腺腫が認められた。VSは20例が海綿静脈洞で、33例 が下錐体静脈洞で $\mathrm{CRH}$ 負荷を行って施行された。VSおよび他の画像検査で異 所性 ACTH 産生腫瘍が疑われたもの、周期性または偽性クッシング症候群で 宽解したものは下垂体手術の適応とならなかった。41例が下垂体手術を施行 され、34例がCD と確定診断された。41例のVSの結果よりVSの診断成績と 問題点を後方視的に検討した。【結果】38例がVSで中枢性と診断され、うち 31 例 $(82 \%)$ がCDであった。VSで異所性の所見であった3例はすべて CDで あった。MRIで腫瘍が認められた 30 例では 28 例 $(93 \%)$ がCDで、腫瘍が認 められなかった 11 例では6例 (55\%) がCDであった。VSと MRIを組み合わ せた場合、MRIで腫瘍がありVSが中枢性の場合 $90 \%$ (25/27例) が、MRIで 腫瘍があり VSが異所性の場合 $100 \%$ （3/3例）が、MRIで腫瘍がなくVSが中 枢性の場合55\%（6/11例）がCDであった。結語】MRIが登達した現在に扔 いては、MRIでの腫瘍の存在が大きく診断に影響し、VSの診断意義は決して 高いものではなかった。

\section{2-4-5末端肥大症症例における術中成長ホルモンモニタ リングと内分泌学的寬解についての検討}

山口 玲、登坂 雅彦、好本 裕平

群馬大学医学部脳神経外科

【はじめに】 GH 産生腺腫の外科的治療の目的は内分泌学的寛解である。その ため、術中の迅速 $\mathrm{GH}$ 測定が試されてきたが、評価方法、有用性は定まってい ない。そこで、術中 $\mathrm{GH}$ 測定結果と術後内分泌学的宽解との関連について検討 を行った。【方法】2011年4月から2019年4月までに群馬大学脳神経外科で内 視鏡下経蝶形骨洞的下垂体腫瘍摘出術を施行された $\mathrm{GH}$ 産生腺腫 36 例中、術 中 $\mathrm{GH}$ モニタリングを施行した 32 例を検討した。術後 2 年以内にIGF-1正常 化かつ $\mathrm{GH}<1.0 \mathrm{ng} / \mathrm{mL}$ または $75 \mathrm{gOGTT}$ 底值 $<0.4 \mathrm{ng} / \mathrm{mL}$ を満たした症例を治 癒例とした。術中 $\mathrm{GH}$ 測定は手術開始後で腫瘍摘出前に前値を測定し、術者 が摘出終了と判断した時点から 30 分、60分、90分、120分後に採血を行った。

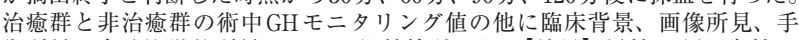
術所見、内分泌学的所見について比較検討した。【結果】男性 13 例、女性 20 例、平均年齢は 46.8 歳であった。治癒群 23 例 $(72 \%) 、$ 非治癒群は 9 例であった。 Knosp grade(3-4)は9例 (28\%)、再発、Knosp grade(3-4)は非治癒群で有意 に多かった $(\mathrm{p}=0.004,0000)$ 。術前の腫瘍径、腫瘍実質 T2 intensity は両群で関 連を認めなかった。術前の $\mathrm{GH}$ は 2 群間で差を認めなかったが、術後 30 分、60 分、90 分、 120 分後の GHは治癒群で有意に低かった(全て $\mathrm{p}=0.000)$ 。 120 分後

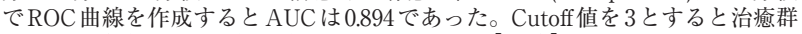
に対する感度は $89 \%$ 、特異度は $87 \%$ であった。【結論】術中 GHモニタリング は、現在まで度々試行されてきた。術後の内分泌学的宽解を予想する基準と して、Abeらの「60分後の GH<4.5 $\mu \mathrm{g} / \mathrm{L} 」$ 、Bergらの「25分後の $\mathrm{GH}$ が前值 の半減」等が報告されている。今回の我々の検討では、 120 分後の $\mathrm{GH} \leqq 3 \mathrm{ng} /$ $\mathrm{mL}$ 以下が術後の内分泌学的宽解とよく関連した。

\section{2-4-8 男性の先端巨大症ではLH分泌の抑制と精巣におけ るLH反応性の低下がテストステロン分泌の低下に 関与する}

西尾 理恵 ${ }^{1,2}$ 、竹下 章 $^{2} 、$ 内田 豊義 ${ }^{1} 、$ 福原 紀章 ${ }^{3}$ 、岡田 満夫 $^{3} 、$ 西岡 宏 ${ }^{3}$ 、山田 正三 ${ }^{3,4}$ 、綿田 裕孝 ${ }^{1}$ 、竹内 靖博 ${ }^{2}$

${ }^{1}$ 順天堂大学大学院 医学研究科 代謝内分泌内科学、 ${ }^{2}$ 虎の門病院 内分泌代謝 科、 ${ }^{3}$ 虎の門病院 間脳下垂体外科、 ${ }^{4}$ 森山脳神経センター病院 間脳下垂体セ ンター

【背景】先端巨大症男性患者では、高頻度に性腺機能低下症を合併するが、過 剩な $\mathrm{GH}$ が、どのような機序で性腺機能低下をきたすのか明らかでない。

【方法】高PRL血症を合併していない未治療の先端巨大症男性患者 112 例を対 象に、外科的治療前の下垂体機能を含む臨床的因子を後方的に収集し、 total testosterone (TT)值およびfree testosterone $(\mathrm{FT})$ 值との関連性を統計学的に検 討した。術後半年から 1 年間にデータを収集できた 56 例に関しては、術後変化 も検討した。

【結果】術前 TTが $230 \mathrm{ng} / \mathrm{dL}$ を回る症例は 112 例中 43 例 (38.4\%)、FTが年 齢別基準值を下回る症例は 86 例 (76.8\%) であった。術前 TT と FT の両者とも GH、IGF-1、腫瘍最大径と負の、LHと正の相関を呈した。重回帰分析によ り、GHがLHとは独立してTT及びFTに最も強い影響を与えることが判明し た。術後 GHは全例で低下し、TTは56例中 45 例 (80.4\%)で上昇、FTは49例 (87.5\%)で上昇した。なお LHは術前 $2.6 \pm 1.6$ から術後 $3.0 \pm 1.5 \mathrm{IU} / \mathrm{L}$ と僅かに増 加、TT/LHおよびFT/LH比は術後、各々 $1.50 \pm 0.84$ 倍 $(\mathrm{p}=0.02) 、 1.68 \pm 1.05$ 倍 $(\mathrm{p}<0.001)$ に増加した。

【考察】高PRL血症を伴わない先端巨大症男性患者では、GH過剩が性腺機能 低下に最も強い影響を与える因子であり、手術によるその是正は性腺機能を 改善した。術後TT/LHおよびFT/LH比が上昇することから、GH過剩による LHの抑制のみならず、精巣での LH応答性の低下も性腺機能低下症の原因と なる可能性が明らかとなった。 


\section{2-4-9 非機能性下垂体腺腫における腫暘径とプロラクチ ン値の関係性の検討}

福原 宏和、福原 紀章、岡田 満夫、西岡 宏 虎の門病院 間脳下垂体外科

【はじめに】高プロラクチン（PRL）血症の原因としてはプロラクチン産生下 垂体腺腫の頻度が最も多いが、視床下部や下垂体茎の障害でも高PRLを引き

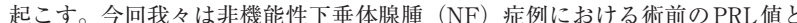
上下方向の腫瘍径との関係を検討した。【対象と方法】2017年1月から2018年 12 月に当院で内視鏡下経蝶形骨洞的下垂体腫噋摘出術 (eTSS) を施行され、 病理所見でNFと診断された158症例（25〜88歳、男性81例、女性 77 例 $)$ の 中から術前のPRL最大值と、術前面像で上下方向の腫瘍径を検討した。ただ し、腎機能障害、甲状腺機能低下症、マクロプロラクチン血症、薬剤性など下 垂体腺腫以外に高プロラクチン血症を引き及ぼす恐九のある症例は除外した。 【結果】術前プロラクチン值は $1 \sim 1051 \mathrm{ng} / \mathrm{mL}$ (中央值 : $21.1 \mathrm{ng} / \mathrm{mL}$ )、上下 方向の腫癔径は8〜 $65 \mathrm{~mm}$ (中央值： $20 \mathrm{~mm}$ ）であった。当院でのプロラク チン值基準值以下 ( $4.4 \mathrm{ng} / \mathrm{mL}$ 以下) となった症例は 4 例であり全例で沉下垂 体機能低下の状態であった。逆に当院での基準値以上 $(31.2 \mathrm{ng} / \mathrm{mL}$ 以上）で あった症例は54例であった。その内訳は男性14例、女性 40例、年秢 $33 \sim 83$ 歳、上下方向の腫瘍径 $11 \sim 65 \mathrm{~mm}$ であった。PRL值と上下方向の腫瘍径との 関係性は認めなかった。【考察・結語】プロラクチン産生下垂体腺腫に扔いて は腫韵径とプロラクチン値はある程度の正関係があるとされている。今回はあ くまで随時プロラクチン值での検討であり、特に女性の年齢や閉経時期、生理 周期などは考慮していなが、上下方向の腫瘍径と PRL值の検到ではそれぞれ の関倸性は認められなかった。垂体茥障害は腄稕の大きさだけではなくどの ように圧排されるかが関倸するのではないかと考えられる。

\section{2-4-11 自己免疫性溶血性貧血を伴った悪性胸腺腫合併抗 PIT-1 下垂体炎の 1 例}

蟹江 慶太郎 ${ }^{1}$ 、井口 元三 ${ }^{2}$ 、山本 雅昭 ${ }^{3}$ 、浦井 伸 ${ }^{3}$ 、志智 大城 ${ }^{1}$ 、 藤田 泰功 ${ }^{1}$ 、福岡 秀規 ${ }^{3}$ 、小川 涉 $^{1}$ 、高橋 裕 $^{1}$

神戸大学大学院医学研究科糖尿病 - 内分泌内科学、 ${ }^{2}$ 神戸大学保健管理七 ンター・医学研究科病態情報学、 ${ }^{3}$ 神戸大学医学部附属病院 糖尿病. 内分泌 内科

【背景】これまで我々は新規疾患概念抗PIT-1下垂体炎(抗PIT-1抗体症候群) を報告し、その機序として胸腺腫に㧍ける異所性PIT-1発現によって自己反 応性細胞障害性 T細胞が生じ、下垂体の特異的細胞障害が引き起こされるこ とを示した。その後本疾患は胸腺腄だけでなく他の悪性腫瘍にも伴う傍腫癔症 候群であることを見出した。今回本疾患第一例の長期経過について報告する [症例】 57 歳男性。42歳時に $\mathrm{GH} \cdot \mathrm{TSH} \cdot \mathrm{PRL}$ の特異的欠損を認め、本疾患と診 断、52歳時に胸腺腫 (正网分類 stage II) と診断され摘出術を施行。55歳時に胸 膜播種性病変が出現、生検で悪性胸腺腫再発と診断され、化学療法(ADOC療 法)を施行し、胸膜播種、後腹膜転移巣は著明に縮小した。57歲時に正球性正 色素性貧血が出現し、ハプトグロビン低值、LDH·間接Bil 高值、網赤血球増 多打よび寒冷凝集素症価上昇から自己免疫性溶血性筫血 (AIHA, 寒冷凝集素 症)と考えられたが、5 ケ月後に自然宽解した。悪性胸腺腫は宽解を維持して いる。【考察】抗PIT-1下垂体炎では、多瀻器に打ける自己免疫性病変を合併 することがある。AIHA では抗赤血球抗体が生じ、補体・食食細胞による溶血 をきたすが、続発性AIHAの基碟疾患として自己免疫疾患やリンパ系腫瘍があ り、寒冷凝集素症では特に固形がんの合併が多いことが報告されている。また その機序としてがん細胞における自己抗原の異所性発現が報告されている。本 例は悪性胸腺腫に伴う続発性AIHA として寒冷凝集素症を発症した可能性があ り、傍腫瘍症候群としての抗PIT-1抗体症候群の新たな合併症と考えられた。

\section{2-4-13 成人成長木ルモン分泌不全症におけるソマプシタ ン週 1 回投与の有効性及び安全性を模討した国際 共同第3相臨床試験（REAL 1 延長試験）}

高野 幸路 1 、Johannsson Gudmundur²、Gordon Murray ${ }^{3} 、$

Rasmussen Michael Hojby ${ }^{4}$ Hakonsson Ida Holme ${ }^{4}$ Svarke Claus 4 田原 重志、 5 Biller Beverly MK ${ }^{6}$

${ }^{1}$ 北里大学 医学部 内分泌代謝内科学、 ${ }^{2}$ Sahlgrenska University Hospital、 ${ }^{3}$ Allegheny General Hospital、 ${ }^{4}$ Novo Nordisk A/S、 ${ }^{5}$ 日本医科大学 脳神経 外科、 ${ }^{6}$ Massachusetts General Hospital

【目的】成人成長ホルモン分泌不全症患者を対象とし、週 1 回投与製郕ソマプ シタンを最大 86 週間投与し、有效性及び安全性を検討した

【方法】主要試験の完了後、ソマプシタン群の患者はソマプシタンによる治療 を継続し、プラセボ群の患者はソマプシタンの投与に切り替えられた。ノル ディトロピンツ群の患者はソマプシタン群又はノルディトロピン群に $1: 1 の$ 比率で無作為に割り付けられた。

【結果】主要試験では 300 例の患者が治験薬の投与を受け、うち272例 (91\%) が延長試験に組み入れられた。治療開始86週後の IGF-I SD スコアは、全群に おいて基準範囲内であった（平均値 [標準偏差]:ソマプシタン/ソマプシタン

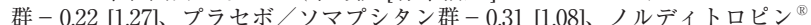
ノノルディトロピン群 -0.24 [1.32]、ノルディトロピン®/ソマプシタン群 $0.39[1.12]) 。$ 体組成関連項目の変化量に、ソマプシタンノソマプシタン群と, ルディトロピン®ノノルデイトロピン®群間で統計的有意差は認められなかっ た（ $\mathrm{p}>0.05 ）$ 有害事象の発現率及び程度は、各群に执いて同様であった。抗 ソマプシタン抗体は検出されなかった。

【結論】主要試験で観察された IGF-I SD スコア及び体組成関連項目における効 果は、延長試験においても認められた。ソマプシタンにおける安全性と忍容性 はノルディトロピン®と同等であった。

\section{2-4-10 当院の免疫チェックポイント阻害薬治療212名の 内分泌分野有害事象の発症予測とその特徵}

類家 裕太郎 ${ }^{1,2}$ 、鈴木 佐和子 1,2 、石渡一樹 ${ }^{1,2}$ 、内藤 久美子 ${ }^{1,2}$ 、

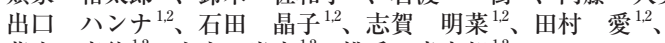
藤本 真德 ${ }^{1,2}$ 、小出 尚史 ${ }^{1,2}$ 、横手 幸太郎 ${ }^{1,2}$

千葉大学医学部附属病院 糖尿病代謝内分泌内科、 ${ }^{2}$ 千葉大学大学院医学研 究院 内分泌代謝・血液・老年内科学

【緒言】癌治療の新たな潮流となった免疫チェックポイント阻害剈(ICI) は、そ の保険適応の拡大に伴い、ICIが併用されるケースも増えている。今後、内分 泌代謝分野の免疫関連有害事象（irAE）に遭遇する機会も更に増加すること が予想される。【方法】過去 5 年間、当院で抗PD- 1 抗体薬（ニボルマブまた はペムブロリズマブ，抗CTLA-4抗体薬（イピリムマブ）にて加療を行った 212 名を対象に甲状腺 irAE と下垂体irAEの更なる発症予測因子を検討すると ともにその特徴を解析した。【結果・考察】甲状腺 irAEは22名に認如られ腎 癌・咽頭癌で多く、ロジステイック解析を用いた発症予測因子解析で、甲状腺 自己抗体に加えて、喫煙歴、分子標的薬の先行治療が同定された。一方、下垂 体irAE発症は16名に訒められ要性里色腪で多く、抗PD-1抗体と抗CTLA-4 抗体の併用で有意に多く、患者背景・治療歴では影響を受けなかった。下垂体 irAEはACTHに加えて、LH, FSH, GH, TSH といった複数のホルモンが同時 に障害されていた。下垂体irAE発症群、甲状腺i AE発症群ともに非発症群に 比較して有意にICI開始後の生存曲線が上昇しており比較的予後良好な群と考 えられた。他科で下垂体i AEとして経過観察されていた症例の中に他の irAE に対するプレドニンによる続発性副㹂不全や副堅性副㹂不全が含まれており。 内分泌代謝専門医でなくとも判断可能な体制を整えることが必須である。

\section{2-4-12 免疫チェックポイント阻害剤によるACTH分泌不 全症亡臨床像、HLAとの関連の検討}

大野 万葉、福田 いずみ、山田 裕士、北島 優子、名尾 敬子、 稲垣 恭子、杉原 仁

日本医科大学付属病院 糖尿病・内分泌代謝内科

【目的】免疫チェックポイント阻害薬(iCI: immune-checkpoint inhibitor)の免 疫関連有害事象 (irAE) のうち迅速な治療を要する点でACTH分泌不全症の 早期診断は重要である。ACTH分泌不全症の発症と HLA の関連についての報 告は少なく、今回、 $\mathrm{iCI}$ でACTH分泌不全症を発症した患者の臨床像と HLA を解析し、発症の予測因子としての有用性を検討した。【方法】 2014-2019 年に当院でiCIにより ACTH分泌不全症を発症した症例の年齢、性別、原疾 患、投与されたiCIの種類、内分泌及び下垂体炎関連検查所見、下垂体MRI、 HLA、副腎不全時の臨床症状・検查所見の解析を行った。【結果】症例は男 性 5例/女性 1 例 (70-83歳) で、肺癌 3 人に Pembrolizmab、悪性黑色腫 2 人に Nivolumab+Ipilimumab、膀脱癌1人にPembrolizmabが投与された。6例と も頭部MRIに異常はなく、Pembrolizmab投与による4例ではACTH 単独久 損を呈した。Nivolumab+Ipilimumab投与により1例はACTH単独欠損と1型 糖尿病を合併、もう1例はACTH, TSH, GH 分泌不全を認めた。抗下垂体抗体 は1例で弱陽性、IgG4 は2 例で高值 (>135 m $/ \mathrm{dL})$ であった。iCI投与から症 状出現までは60-210日であり、症状発現から発見までに2-50日間を要してい た。検查所見では低血糖 3 例、好酸球上昇 3 例、低 $\mathrm{Na}$ 血症 2 例と、5/6 例でい ずれかの所見を認めた。畽瘍縮小効果は $5 / 6$ 例で認めた。 HLA は A24(24:02) HLA-DR15(15：01、15：02)の頻度が多かった(A24 (4/6))、DR15(5/6例))。【考 察】一般検查所見 (血糖、好酸球数、 $\mathrm{Na}$ 值)の組合せで $83 \%$ (5例)の検出が可能 であった。HLAについては日本人出現率が高いものであり、発症りスクの予 測因子となり得るかについてはさらなる検討が必要である。

\section{2-4-14 日本人成人成長木ルモン分泌不全症患者における ソマプシタン週 1 回投与の安全性及び有効性を検 討した国内第3相臨床試験 (REAL JP)}

大塚 文男 ${ }^{1}$ 、高橋 裕 $^{2} 、$ 田原 重志 ${ }^{3} 、$ Rasmussen Michael Hojby ${ }^{4} 、$ 小川 憲久 ${ }^{5}$ 、高野 幸路 ${ }^{6}$

${ }^{1}$ 岡山大学大学院 医歯薬学総合研究科、2 神戸大学大学院 医学研究科、 ${ }^{3}$ 日本 医科大学、 ${ }^{4}$ Novo Nordisk A/S、 ${ }^{5}$ ノボノルディスクファーマ株式会社、 ${ }^{6}$ 北里大学 医学部

【目的】日本人成人成長ホルモン $(\mathrm{GH})$ 分泌不全症患者を対象に週 1 回投与製 剂ソマプシタンと1日1回投与製郕ノルディトロピン® 52 週投与し、安全性、 有効性及び治療満足度を比較する。

【方法】成人 $\mathrm{GH}$ 分泌不全症と診断され、すでに 1 日 1 回投与の $\mathrm{GH}$ 製郕で治療 中の患者を 3:1 の割合でソマプシタン群又はノルデイトロピン®群に割り付け、 20 週間の用量調整後、32 週間維持用量にて治療した。

【結果】62例中46例の患者がソマプシタン群に、16例がノルディトロピン®群 に無作為割り付けされ、60例が試験を完了した。ソマプシタン及びノルディ トロピン®群の有害事象の発現率は同様であった（ソマプシタン群: 312.7/100 人・年、ノルディトロピン®群: 309.8/100人・年)。投与期間中、抗ソマプシ タン抗体の産生は認められなかった。 52 週後のIGF-I SD スコアの平均值士 標準偏差は、ソマプシタン群 $0.61 \pm 0.68$ 、ノルディトロピン®群 $0.52 \pm 0.57$ で あった。52週後、総脂肪組織、皮下脂肪組織及び内臟脂肪組織の変化量に両 群間で差は認められなかった（群間差の推定値 [95\% CI]: - 1.74 [-18.13; 14.66]、 $-11.53[-35.54 ; 12.48]$ 及及び-12.85 [-47.31; 21.62] $\left.\mathrm{cm}^{2}\right)$ 。

【結論】日本人成人 $\mathrm{GH}$ 分泌不全症患者に拀けるソマプシタンの安全性と忍容性 はノルディトロピン®と同等であった。ソマプシタンの投与により IGF-I SD スコアの平均値は基準範囲にコントロールされ、脂肪組織の変化量はノルディ トロピンツ群と同様であった。 


\section{2-4-15 小肾頭蓋咽頭腫患者11例における成長の検討}

平野 泰大 ${ }^{1} 、$ 土岐 真智子 ${ }^{1}$ 、新田 祐佳 $^{1}$ 、花川 純子 $^{1}$ 、

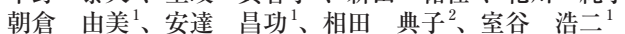

1神奈川県立こども医療センター内分泌代謝科、 ${ }^{2}$ 同 放射線科

【背景】頭蓋咽頭腫では、腫瘍による圧迫、ないし、治療による合併症として 視床下部・下垂体障害による沉下垂体機能低下症が生じうる。また、治療後に GH分泌不全を伴うにもかかわらず成長率が保たれる growth without growth hormone (GWGH) が知られているが、明確な機序は解明されていない。【方 法】過去 20 年間に当院に通院歴がある小児頭蓋咽頭腫の患者 11 例について 術後の成長パターンにより GWGHと考えられる5名（GWGHあり群）とそ れ以外の6例（GWGHなし群）に分け、術前の成長率や術前後のBMIの変化 について検討した。【結果】術後1年の成長率SDSは、GWGHあり群で+4.60 $(+0.81-+9.20)$ であったのに対し、GWGHなし群で-5.30 (-9.19--1.89) であった。術前の成長率SDSは、GWGHあり群で-2.00 $(-4.46-+0.76)$ GWGH なし群で-3.88 (-7.17--2.04) であった。BMI-SDSの変化は、GWGH あり群で $+1.4(+0.15-+2.79) 、 G W G H な し$ 群で+0.10 $(-2.07-+3.44)$ で あった。【考察】GWGHなし群では、術前から成長率の低下を認め、術後さら に成長率の低下傾向を認めた。一方、GWGHあり群では、術後にBMIの急激 な上昇を認めることが多いものの、必ずしもインスリン高值を認めなかった。 また、術前の成長率は多くの症例で保たれていたが、一部の症例で低下してい た。このことから、GWGHには術後の栄養やホルモン分泌の変化で説明でき ない要素があるものと推測される。GWGH現象の機序解明には、さらなる症 例の蓄積が必要である。

\section{2-4-17 QT延長，致死性不整眽を呈したACTH分泌不全 症の3例}

浦井 伸 ${ }^{1}$ 、山本 雅昭 ${ }^{2}$ 、福岡 秀規 ${ }^{2}$ 桂 由佳梨 ${ }^{2} 、$ 内山 奏 ${ }^{1} 、$

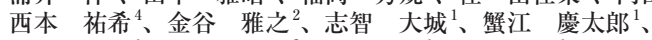

藤田 泰功 ${ }^{1}$ 、井口 元三 ${ }^{3}$ 小川 涉 ${ }^{1}$ 高橋 裕 $^{1}$

1神戸大学大学院医学研究科糖尿病 - 内分泌内科学、 ${ }^{2}$ 神戸大学医学部附属 病院 糖尿病・内分泌内科、 ${ }^{3}$ 神戸大学保健管理センター・医学研究科病態情 報学、 ${ }^{4}$ 兵庫県立姫路循環器病センター 糖尿病・内分泌内科

【背景】ACTH 分泌不全症では, QT 延長と心室頻拍(VT), 心室細動(VF)など致 死性不整脈を呈することがある。

【症例1】60歳女性. 56 歳時意識消失て搬送, QT 時間 $(\mathrm{QTc})$ 延長 $(577 \mathrm{~ms}), \mathrm{VT}$, VFを認め, ACTH $2.3 \mathrm{pg} / \mathrm{mL}, \mathrm{F}<0.2 \mu \mathrm{g} / \mathrm{dL}$, その他の下垂体ホルモンや下 垂体MRIに異常なく, ACTH単独欠賣症と診断, ヒドロコルチゾン (HC) 開始後 QTcは $469 \mathrm{~ms}$ へ改善した

【症例2】 35歳女性, 31歳時甲状腺機能低下症，32歳時に意識障害を来し， QT c 延長 $(770 \mathrm{~ms})$, VT, VFを認め, 部分型下垂体機能低下症 $(\mathrm{ACTH}, \mathrm{TSH}$ 分泌不 全)と診断, empty sellaを呈していた. HCとLT4補充でQTcは449 msへ改善 した。経過中に HCを $10 \mathrm{mg}$ へ減量すると QTcが $488 \mathrm{~ms}$ まで再度延長を認めた。 【症例3! 64歳女性. 食思不振の精查で受診, empty sella, 部分型下垂体機能低 下症 (ACTH, TSH 分泌不全) と診断, HC と LT4 補充を開始した。初診時 QTC 延長 $(476 \mathrm{~ms})$ を認めたが，補充後 $421 \mathrm{~ms}$ 一改善，HC非内服下ではQTcが再度 延長 $(443 \mathrm{~ms})$ した.

【考察】今回 HC 補充によって QTc 延長が可逆的に改善することを確認し得た 3 例を経験した。糖質コルチコイドは筋小胞体での Ca輸送，Kチャネル発現を制 御しているが，原発性より中枢性副腎不全でのQT延長や致死性不整脈がより 多く報告されている点，動物実験で $a$ MSHの抗不整脈効果が示されている点か ら、糖質コルチコイドに加え ACTH分泌の低下がその発症機序に関与している のかもしれない

\section{2-4-19 新生児マススクリーニングを契機に発見された先 天性甲状腺機能低下症のBMIの検討}

中山 加奈子 ${ }^{1}$ 、菱村 希 ${ }^{1}$ 、山口 健史 ${ }^{1}$ 、石津 桂 $^{2}$ 、山岸 卓也 ${ }^{3} 、$ 田島 敏広 4 、中村 明枝

${ }^{1}$ 北海道大学医学部 小児科、 ${ }^{2}$ 北円山 杜のこどもクリニック、 ${ }^{3}$ 札幌市衛生 研究所、“とちぎ子ども医療センター小児科

【背景】先天性甲状腺機能低下症 (CH) は本邦の出生 3,000-5,000名に対して1名 と推定されている。CHの新生児マススクリーニング (NMS) は全国実施に先 駆け、札幌市では1978年6月から開始され、長期的に経過をみている症例は 増加している。CHは一般集団と比較して adiposity rebound (AR)が早いこと が報告されており、早期ARは成人期肥满と相関するとされる。【目的】 NMS を契機に診断され、当院で加療を受けたCH患者の AR る。【方法と結果】対象は1994年4月以降にNMSで発見され、当院を受診し た $\mathrm{CH}$ 患者のうち2019年10月時点で15歳以上かつ評価時に補充療法を継続し ていた症例。治療開始時、AR時、15歲以上 19 歲未满時占の情報を診療録を用 いて後方視的に検討した。症例数は 32 例 (男性14例、女性 18 例)、治療開始日 齢中央值は18日 (10-67日) だった。ARの平均年齢は男性 4.4 \pm 2.4 歳 (1.0-8.9 歳)、女性 $5.5 \pm 2.4$ 歳 $(1.2-8.9$ 歳）であり、Koyama らの報告と比較すると女 性のみ有意に高かった $(\mathrm{p}=0.021)$ 。評価時年齢は男性 $17.1 \pm 1.2$ 歳、女性 $16.3 \pm$ 12 歲であった。 BMI は男性 $21.3 \pm 30$ 女性 $201 \pm 27$ で、平成29年度国民栄盖 健康調查に打ける15-19歳の BMI (男性 21.1 1 3.6、女性 20.7 2 2.5) と有意差は なく $(\mathrm{p}=0.088 、 \mathrm{p}=0.426) 、 \mathrm{AR}$ 時の BMI、月齢と弱い相関を認めた。【考察】当 院に㧍ける検討ではCH患者は一般集団と比較してARの時期は同等あるいは 遅れており、15-18歳時のBMIは有意差を認めなかった。定期受診により体重 增加に早めに介入されたと推察される。結論】 NMSにより発見された $\mathrm{CH} の$ 15-18歳時BMIは一般集団と有意差を認めない。

\section{2-4-16 中枢性副腎不全に対するDHEA-Sの対数变換・年 齢性別毎SDスコアの診断的有用性の検討}

石渡 千聖、江戸 直樹、盛田 幸司、佐山 遥平、鈴木 崇史、 中島 利菜、平田 帆奈美、眞弓 大輝、坂本 美貴、岡本尔扔り、 内野 卓也、男澤 悠貴、宇野 健司、塚本 和久、石川 敏夫 帝京大学 医学部 内分泌代謝・糖尿病内科

【背景】中枢性副腎不全 (CAI) の診断には、インスリン負荷試験や迅速 ACTH負荷試験が用いられる。一方、血清DHEA - S も参考になるが、年齢 性別で基準值が異なるのが難点である。

【目的】 CAI診断での DHEA - Sの意義を検討する。

【対象】2014年4月～2019年7月に迅速 ACTH負荷試験と DHEA - S測定を 行った 例・ 女性 33 例

【方法】迅速 ACTH負荷試験コルチゾール頂値（Fmax） $18 \mu \mathrm{g} / \mathrm{dL}$ をカットオ フにCAI群と非CAI群に分け、DHEA - S 值をU検定で比較。また全体を対 象に DHEA - S值と Fmax の相関を Spearman 検定で評洒した。次に正規性を 仮定するため DHEA - S 実測值と年齢性別毎基準值を対数変換しln DHEA S SD スコアとL、Fmaxとの単回㷌分析、CAI有無に関するロジスティック 回帰分析とROC解析を行った。

【結果】CAI群（30例）では非CAI群（28例）に比LDHEA - S は有意に低 值で（ $p<0.01$ 、CAI群：239.0 $(20-2950) \mu \mathrm{g} / \mathrm{dL}$ 、非CAI群 : $814.5(160$ - 2210） $\mu \mathrm{g} / \mathrm{dL}) 、 F \max$ と有意に相関した $(\rho=0.589 、 p<0.01)$ 。また、 $\mathrm{ln}$ DHEA-S SD スコアは、単回帰分析でFmaxの有意な説明変数となり $(\beta=$ $3.78(2.74-4.83) 、 p<0.01) 、 \mathrm{CAI}$ 有無に関しても有意な説明変数となっ た $(\mathrm{OR}=0.23(0.11-0.50) 、 p<0.01)$ 。 ROC 解析では本スコア -0.268 で感度 $82.1 \%$ 、特異度 $76.7 \%$ 、AUC $: 0.861(0.762-0.96)$ となった。

【考察】本スコアは副腎皮質機能評価の一助となった。特にー 0.82 以下では全 例CAI と判定される症例であり、補助診断としての有用性が示唆された。

\section{2-4-18 CRH負荷試験による副腎皮質機能低下症・不全症 カットオフ值策定の試み}

三井 由加里 ${ }^{1} 、$ 飯塚 裕斗 ${ }^{1,2} 、$ 田中 智明 ${ }^{1,2} 、$ 遠藤 逸朗 ${ }^{1,2} 、$

倉橋 清衛 ${ }^{1,3}$ 、吉田 守美子 ${ }^{1} 、$ 山口 佑樹、山上 紘規 ${ }^{4}$ 、

藤中 雄一 ${ }^{4}$ 、森本 佳奈 ${ }^{5}$ 、白神 敦久 ${ }^{5}$ 、福本 誠二 ${ }^{6}$ 、松本 俊夫 ${ }^{6}$

1 徳島大学病院内分泌代謝内科、 2 德島大学大学院医歯薬学研究部血液内分泌 代謝内科学、 ${ }^{3}$ 徳島大学大学院医歯薬学研究部生体機能解析学分野、 ${ }^{4}$ 徳島県 鳴門病院内科、 ${ }^{5}$ 德島県立中央病院糖尿病 - 代謝内科、 ${ }^{6}$ 德島大学藤井節郎記 念医科学センター

【背景】副㹂皮梊機能低下症・不全症(AI) は生命に関わる重篤な状熊であり、 その診断は正確になされるべきである。われわれは、 $\mathrm{CRH}$ 負荷試験結果を用 いて簡易なカットオフ值策定が可能かどうか検討した。【方法・結果】德島大 学病院扔よび関連施設にて 2011/4から 2018/12 までにCRH負荷試験を行った 209 症例(平均年齢57.8) について解析した。 CRH 負荷試験後に屯用を含むコー トリル補充を行った症例を AI、CRH負荷武験後にコートリル補充を行わな かった症例を副婜機能正常(AS) と定義した。AS抢よびAIに拈いてF前値 30 分值,peak 值はそれぞれ、 $11.32+-4.16$ vs $3.60+-4.11 ; \mathrm{p}<0.0001,17.76+-4.60$ vs $5.22+-5.30 ; \mathrm{p}<0.00001,19.61+-4.54$ vs $5.74+-5.79 \mu \mathrm{g} / \mathrm{dl} ; \mathrm{p}<0.00001$ であり、い ずれも ASで高值であった。さらにF前值5.9以下(ROC AUC 0.901; $\mathrm{p}<0.001$ ) F頂值 13 以下 (ROC AUC 0.962; $\mathrm{p}<0.0001) 、 \mathrm{~F}$ 前值 + 頂值 21.7 以下 (ROC AUC 0.959. $\mathrm{p}<0.0001) 、 F 30$ 分值 +頂值 24.4 以下 $($ ROC AUC 0.965. $\mathrm{p}<0.0001) 、 \mathrm{~F}$ 前值 + 30 分值+頂値 34.7 以下 (ROC AUC 0.958; $\mathrm{p}<0.0001)$ がAIのカットオフとして 決定された。AI診断において、ACTH值や年齢性別基準を勘案したDHEA-S 值などを組み合わせた AUC 值は、ここで示したF予備能パラメーターのAUC 値を上回ることはなかった。【結論】 CRH負荷試験における F30分值＋頂值24.4 以下を $\mathrm{AI}$ のカットオフ值として提唱したい。

\section{2-4-20 新規ヨードトランスポーターSLC26A7遺伝子変 異による甲状腺機能低下症の発見と臨床的課題}

鈴木 敦詞 ${ }^{1} 、$ 青山 幸平 ${ }^{1} 、$ 吉田 あや ${ }^{1} 、$ 山口 直哉 1 、田中 達之 ${ }^{1,4}$ 石井 順 ${ }^{2,3}$ 、菅間 博 ${ }^{2}$ 、齋藤 伸治 ${ }^{1}$ 、水野 晴夫 ${ }^{1,5}$

名古屋市立大学大学院医学研究科 新生児 - 小児医学分野、 ${ }^{2}$ 杏林大学医学 部 病理学教室、 ${ }^{3}$ 獨協医科大学医学部 病理学講座、 ${ }^{4}$ 豊橋市民病院 小览科、 5 国際医療福祉大学医学部 小児科学

【背景】我々は2019年に甲状腺滤胞細胞の管腔側に存在する新規ヨードトラン

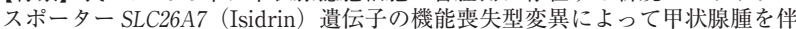
う先天性甲状腺機能低下症 $(\mathrm{CH})$ を発症することを報告したきヨードトラン スポーター遺伝子変異による疾患は一般的に、ヨード摂取状況によってその表 現型が変化することが知られており、この疾患の臨床的問題点について考察 する。【症例 1 ：兄】 現在、22歳、男性。新生睍マススクリーニング陽性でCH と診断。2歳で治療中止としたが、7歳時に再度、甲状腺機能低下症ならびに 甲状腺腫を認め、LT4内服を再開した。症例 2 ：妹】現在、20歳、女性。新 生児マススクリーニングは正常。5 歳時に甲状腺腫を主訴に当科を受診。甲状 腺機能低下症求よび著明な甲状腺腫を認め、LT4 内服を開始した。両症例に SLC26A7 遺伝子のナンセンス変異 (c.1498C > T;p.Gln500Ter) をホモ接合性に 同定した。【考察】症例 2 は症例 1 と同様の null変異を有しながらも新生児マス スクリーニングが正常であったこここと㤌高ヨード摄取環境にある本邦で は、本遺伝子変異によるCHの一部がマススクリーニングで見つからず、低身 長などの合併症が生じてから発見される可能性を示唆するものである。また過 去の報告のほとんどがnull変異であり、より遺伝学的インパクトの弱い変異で は甲状腺腫の久を示す症例も存在する可能性がある。その臨床像を把握するべ く、成人症例に対象を広げて検討することが急務である。 


\section{2-4-21 サイロブロブリン遺伝子異常症患者における甲状 腺体樍と甲状腺ホルモンバランス}

笠原 俊彦、伊藤 充、樑田 修司、中村 友彦、高坂 和芳、 久門 真子、工藤 工、西原 永潤、西川 光重、中村 浩淑、 宮内 昭

隈病院

【背景と目的】我々は、橋本病において甲状腺体積（TV）依存性にFT3 FT4比が高值となることを報告した（Endocrine. 2019;64:584-590、Endocr J. 2019;66:763-768)。甲状腺ホルモン合成障害も甲状腺が腫大し時に巨大甲状腺 腫を呈するが、今回、サイログロブリン遺伝子異常症（TGM）患者のTVと FT3/FT4比の関連性を検討した。【対象と方法】遺伝子解析にてTGM と診 断された46例のうち、初診時にLT4 補充を受けていなかった 7 例（年齢中央 值 46歳; $24-73$ 歳, 男性 3例, 女性 4 例) を診療データベースから抽出した。 FT4值、FT3值、FT3/FT4比とTVの相関について検討した。【結果】FT3 FT4比は、TVと有意な正相関を示した $(\mathrm{r}=0.8209, \mathrm{p}<0.05)$ 。 FT3はTVと 正の相関（r=0.3685, $\mathrm{p}<0.05 ）$ を示す一方、FT4は TVと負の相関（r=0.1813, p <0.05) を示した。考察】Kanouらは、TGMにおける FT3/FT4 比高値とD2 活性立進について報告した（JCEM 2007;92:1451-1457）。我々は、橋本病巨大 甲状腺腫において、D1,D2 活性の克進、さらに各酵素と TVの正相関について 報告した (Endocrine. 2019;64:584-590)。今回の検討により、橋本病と同様、 TGMにおいても TV 依存性にFT3/FT4比が高值となり、脱ヨウ素活性立進の 関与が示唆された。【結論】TGMにおいてもFT3/FT4比は、TVと有意な正 相関を示す。

\section{2-4-23 ベザフィブラートによる甲状腺機能低下をきたし た甲状腺ホルモン不応症の 1 例}

山下 貴史 ${ }^{1,2}$ 、山内 一郎 ${ }^{1}$ 、花岡 郁子 ${ }^{2}$ 、兒井 健 ${ }^{3}$ 、伯田 琭郎 ${ }^{1}$ 、 植田 洋平 ${ }^{1}$ 、藤井 寿人 1 、稲垣 暢也 ${ }^{1}$

京都大学大学院 医学研究科 糖尿病・内分泌・栄養内科学、 ${ }^{2}$ 市立岸和田市 民病院 代謝· 内分泌内科、3 静岡県立総合病院 遺伝診療科

【背景】以前に報告した甲状腺ホルモン不応症 (RTH $\beta$ ) の症例（日本内分 泌学会雑誌. 94;693:2018) についてその後興味深い経過を呈したため再度報 告する。【症例】 51 歳男性。X-4年よりべザフィブラート (BZ) $200 \mathrm{mg} /$ 日の 内服が開始されていた。X年に体重減少を主訴に当科初診となり、TSH 4.67 $\mu \mathrm{IU} / \mathrm{mL} 、 \mathrm{fT} 34.06 \mathrm{pg} / \mathrm{mL}$ fT4 $2.52 \mathrm{ng} / \mathrm{dL}$ と異常を認めた。TgAb $12.0 \mathrm{IU} /$ $\mathrm{mL} 、 \mathrm{TPOAb} 5.0 \mathrm{IU} / \mathrm{mL} 、 \mathrm{TRAb} 1.0 \mathrm{IU} / \mathrm{L}$ と陰性で、MRIでは下垂体に腫瘍は 指摘されず、THRB遺伝子にG347R 変異を認めRTH $\beta$ と診断した。X+1年頃 から徐々にTSHの上昇、fT3及びfT4の低下を認め、X+3年にはTSH $92.19 \mu$ $\mathrm{IU} / \mathrm{mL} 、 \mathrm{fT} 33.05 \mathrm{pg} / \mathrm{mL} 、 \mathrm{fT} 40.62 \mathrm{ng} / \mathrm{dL}$ と顕性の甲状腺機能低下症を呈した。 TSH 上昇を抑えるためレボチロキシン (IT4) $100 \mu \mathrm{g} /$ 日の投与を行うもTSH $69.80 \mu \mathrm{IU} / \mathrm{mL} 、 \mathrm{fT} 33.36 \mathrm{pg} / \mathrm{mL} 、 \mathrm{fT} 41.70 \mathrm{ng} / \mathrm{dL}$ と効果にそしかった。BZを 中止した所 3 週間後にはTSH $13.10 \mu \mathrm{IU} / \mathrm{mL} 、 \mathrm{fT} 35.05 \mathrm{pg} / \mathrm{mL} 、 \mathrm{fT} 42.45 \mathrm{ng} /$ $\mathrm{dL}$ と甲状腺機能低下症の改善を認め、LT4中止後も TSH $0.98 \mu \mathrm{IU} / \mathrm{mL} 、 \mathrm{fT} 3$ $8.10 \mathrm{pg} / \mathrm{mL}$ 、fT4 $2.86 \mathrm{ng} / \mathrm{dL}$ と甲状腺機能低下は認めていない。rT3/FT4 比は BZ内服中 0.30 、内服中止後 0.16 であった。【考察】少なくとも G347R 変異を有 するRTH $\beta$ 症例に扔いてはBZ投与により甲状腺機能低下が惹起される事が 明らかとなった。我々のRTH $\beta$ マウスモデルの検討では、BZ投与で肝での 3 型脱ヨード酵素の mRNA 発現増加が見られており、本症例でも BZ投与中に $\mathrm{rT} 3 / \mathrm{FT} 4$ 比の増加を認めていた事と矛盾しない。同様の報告はなく、RTH $\beta$ の治療を考える上で重要な症例であり報告する。

\section{2-4-25 甲状腺癌全摘後TSH抑制療法患者における血清甲 状腺ホルモン測定に関する再考}

伊藤 充、羽田 幹子、正木 ゆづき、南方 瑞穂、中村 友彦、

高坂 和芳、笠原 俊彦、工藤 工、郷司 克己、西原 永潤、 深田 修司、西川 光重、中村 浩淑、宮内 昭 隈病院

【背景と目的】甲状腺癌全摘後は、再発リスクに応じてTSH值を指標に $\mathrm{LT}_{4}$ の 投与が行われる。我々は、TSH完全抑制でFT 身体指標は甲状腺中毒傾向となり、TSH軽度抑制でFT は術前と同等、代謝 身体指標は機能正常傾向、TSH正常で $\mathrm{FT}_{3}$ は低值、代謝・身体指標は機能低 下傾向となり、一方、 $\mathrm{FT}_{4}$ は全群で術前に比して高値となることを報告した (Thyroid27p484, Endocr J in press)。今回、甲状腺機能の指標として $\mathrm{FT}_{4}$ ない し $\mathrm{FT}_{3}$ を測定した場合の基準範囲との適合性について検討した。【対象と方法】 2019年 1 月以降に当院学㟝し、術後 6 ケ月以上経過した甲状腺乳頭癌全摘後 TSH抑制療法患者 3213例(男性581例、女性 2632例)。治療指標は低リスク症 例がTSH軽度抑制、高リスク症例がTSH完全抑制であった。TSHに加えFT ないし $\mathrm{FT}_{3}$ を測定していた場合の基準範囲内に占める割合を比較した。ホルモ ン測定にはエクルーシス試薬(Roche)を用いた。【結果】(1)3213例中、FT $\mathrm{FT}_{4}$ 測 定が591件、 $\mathrm{FT}_{3}$ 測定が 2675 件であった。FT、測定件数の内、149件 $(25.2 \%)$ が 基淮籁囲内、442件 $(74.8 \%)$ が高值であった $\mathrm{FT}_{3}$ 湘定件数の内、46件(1.7\%)が 低值、2477件 (92.6\%)が基準範囲内、152件 (5.7\%) が高值であった。(2)FT 3 高值 となっている152件のうち 143 件 (94.1\%)に抢いて、TSH完全抑制 ( $\mathrm{mL}$ )となっていた。【結論】全摘後 TSH 抑制療法に执いて、FT測定を行うこ とは、病態把握のみならず基準範囲との適合性からも $\mathrm{FT}_{4}$ 測定よりも有用であ ることが示された。FT 高值となっている患者は甲状腺中毒状態が疑われ、低 リスク症例あるいは合併症が疑われる場合は $\mathrm{LT}_{4}$ 減量が妥当である。

\section{2-4-22 甲状腺ホルモン不応症と自己免疫性甲状腺疾患の 合併例の臨床像の検討}

羽田 幹子、西原 永潤、中村 友彦、高坂 和芳、笠原 俊彦、 工藤 工、伊藤 充、郷司 克己、深田 修司、西川 光重、 中村 浩淑、宮内 昭

隈病院

【目的】甲状腺ホルモン不応症 (RTH $\beta$ ) は自己免疫性甲状腺疾患 (AITD)の合併 が多い可能性が報告されている. 本邦でも RTH $\beta$ にバセドウ病や慢性甲状腺 炎を合併した症例は散見されるが, 合併頻度は明らかでない. 本邦のRTH $\beta$ と AITD合併の臨床像を明らかにすることを目的に検討した。【方法】当院でTR $\beta$ 遺伝子変異を認めた RTH $\beta 43$ 家系, 60 症例 (男性 18例, 女性 42 例, 診断年齢 34(25-50)歲 フォロー期間 3.1(0-6.5) 年, 変異30種)を対象に甲状腺自己抗体の 陽性率, 陽性例の臨床像を検討した. nonTR-RTH14 例 (男性 7例, 女性 7例)の 抗体陽性率も検討した.【結果】 60 症例のうち, 抗 TPO抗体, 抗 Tg抗体のいず れかが陽性の例は 23 例, 男性 8/18例(44.4\%), 女性 16/42例 (38.1\%) であった 経過中 AITDにより甲状腺機能異常を呈した例が 7 例 (甲状腺機能低下症 5 例, 無痛性甲状腺炎 1 例, バセドウ病 1 例)あり，いずれも抗体陽性例であった 7 例 中甲状腺機能低下症 2 例, 無痛性甲状腺炎, バセドウ病合併の 4 例は同一家系に 属していた. nonTR-RTH14例の抗体陽性例は 1 例 (女性, 抗 TPO抗体陽性)で あった.【考察】本邦の検診の抗Tg抗体/抗TPO抗体の陽性率は $18 \%$ (男性 $11 \%$ ，女性 $25 \%$ ) と報告されている.今回の検討結果で,一般と比較してRTH $\beta$ で抗体陽性率が高く，特に男性で高いことが示された RTH $\beta$ と同様の臨床 像を示す nonTR-RTH14例では抗体陽性率は高くなく, 抗体陽性となる機序を 考える上で興味深い結果であった. RTH $\beta$ にバセドウ病や甲状腺機能低下症を 合併した場合, 治療には格別の注意が必要となる. RTH $\beta$ ではAITDを合併し ている可能性が高いことを理解し，抗体陽性症例では甲状腺機能の変化を注意 深くみていく必要がある。

\section{2-4-24 フィブラート製剤投与に伴い甲状腺機能の変動を 認めた 1 例と自験例での検討}

須川 玩、山内 一郎、山下 貴史、伯田 珧郎、植田 洋平、 藤井 寿人、田浦 大輔、曽根 正勝、稲坦 暢也 京都大学大学院 医学研究科 糖尿病・内分泌・栄養内科学

【症例】 56 歳女性【主訴】浮腫【現病歴】X-2 年 5 月に甲状腺腫大を指摘され た。X-1年 6 月に手足の浮腫を認め受診したところ、甲状腺機能低下症を認 め (FT4 $0.09 \mathrm{ng} / \mathrm{dL}$ 、TSH $131.2 \mu \mathrm{IU} / \mathrm{mL}$ )、抗TPO抗体 $600 \mathrm{IU} / \mathrm{mL}$ 、抗 Tg 抗体 $1156 \mathrm{IU} / \mathrm{mL}$ であり橋本病と診断された。レボチロキシンを $100 \mu \mathrm{g} /$ 日 まで漸増され、甲状腺機能は正常となっていた。【経過】X年5月（FT4 1.45 $\mathrm{ng} / \mathrm{dL} 、 \mathrm{TSH} 4.088 \mu \mathrm{IU} / \mathrm{mL}$ ) に高中性脂肪血症に対しフェノフィブラート $80 \mathrm{mg} /$ 日を開始したところ、X年7月の受診時にFT4が上昇していた（FT4 $1.77 \mathrm{ng} / \mathrm{dL} 、 \mathrm{TSH} 6.911 \mu \mathrm{IU} / \mathrm{mL})$ 。その後、湿疹が出現したためフェノフィ ブラート内服を自己中断され、X 年 9 月に受診した際にはFT4 4 年 5 月の開 始前と同程度であった（FT4 $1.46 \mathrm{ng} / \mathrm{dL} 、 \mathrm{TSH} 5.436 \mu \mathrm{IU} / \mathrm{mL})$ 。ベザフィブ ラート $200 \mathrm{mg} /$ 日にて高中性脂肪血症に対する治療を再開したが、X年11月 の受診時にFT4の上昇とTSHの低下を認めた（FT4 $1.78 \mathrm{ng} / \mathrm{dL} 、 \mathrm{TSH} 1.573$ $\mu \mathrm{IU} / \mathrm{mL})$ 。ベザフィブラート投与前後に甲状腺機能を測定していた自験 7 例を検討したところ (中央值、四分位範囲で記載)、FT4は投与前 $1.16 \mathrm{ng}$ /

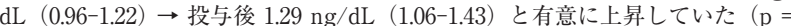
0.006)。【結語】フィブラート製剂投与にてFT4が上昇した1例を経験したが、 既報が全くないため自験例での検討を追加し、他の症例でも同様の現象が生じ ることを確認した。本症例の経過からはフィブラート製郕間で差異がある可能 性もある。

\section{2-4-26 肝細胞癌患者40例のレンバチニブによる甲状腺機 能への影響}

中島 康代 ${ }^{1}$ 、畑中 健 $^{3}$ 、五十嵐 隆通 ${ }^{4}$ 堀口 和彦 ${ }^{1}$ 、吉野 聡 $^{1} 、$ 松本 俊一 1 、石田 恵美 ${ }^{1} 、$ 山田 英二郎 ${ }^{1} 、$ 柿崎 暁 ${ }^{2}$ 調 憲 ${ }^{4} 、$ 山田 正信 ${ }^{1}$

${ }^{1}$ 群馬大学 大学院 医学系研究科 内分泌代謝内科学、 ${ }^{2}$ 群馬大学大学院医学系 研究科消化器肝臓内科学、 ${ }^{3}$ 群馬県済生会前橋病院、 ${ }^{4}$ 群馬大学大学院医学系 研究科肝胆膵外科学

【緒言】2018年3月、レンバチニブは切除不能な肝細胞癌の一次治療薬として 世界に先駆け本邦で最初に承認された。チロシンキナーゼ阻害郕による甲状腺 機能障害はこれまでも報告があるが、肝機能障害や肝硬変を合併する肝細胞癌 患者に対するレンバチニブによる甲状腺機能障害の詳細は検討されていない 今回我々は当院などでレンバチニブを投与されたTSH正常範囲内の肝細胞癌 患者 40 例(平均年齢 $71 \pm 10$ 歳)に扔ける甲状腺機能障害の実態を調查した。【結 果】レンバチニブ投与後初回採血でTSH值は有意に上昇し(使用前 TSH $(\mu \mathrm{U})$ $\mathrm{ml})$ 中央值 2.3 , 使用後 5.8 観察期間中央值 15.5 日 paired $\mathrm{T} \mathrm{p}<0.01)$ 、上昇した TSH は薬剂使用中は多くで高值のままであった。TSH $\mu \mathrm{U} / \mathrm{ml}$ 以上の上昇例 は2 23 例 $55 \%$ と高率であった。FT3值は薬剤使用後 2 回目採血で有意に低下し、 (使用前 $\mathrm{FT} 3(\mathrm{pg} / \mathrm{ml}) 2.3$ ，使用後 2.2 観察期間中央值 42.5 日，paired $\mathrm{T} \mathrm{p}<0.05$ )、 薬剤使用中はFT3は低值のままであったが、FT4值は使用前後で明らかな変 化は認めなかった。甲状腺の Grade3 以上の有害事像例はいなかった。年齢や 性別、薬剤投与量、HCV 感染、PS, Child- Pugh score, BCLC scoreなどの甲 状腺機能変化への関与は明らかでなかった。【結語】レンバチニブによる甲状 腺機能変化は早期より高率に出現するが、多くは軽度の変化であり、患者は高 齢者で肝予備能低下例が多いことから、甲状腺ホルモン製剂の使用は慎重に検 討すべきと考えられた。 


\section{2-4-27 マクロTSH血症におけるTSH値の乘離に関する検 討}

星山 綾子 ${ }^{1}$ 、杉澤 千穂 ${ }^{1} 、 川 口 \quad$ 明子 ${ }^{1}$ 、盛崎 瑞葉 ${ }^{1} 、$

蛭間 真梨乃 ${ }^{1} 、$ 鈴木 菜美 ${ }^{1} 、$ 鈴木 美穂 ${ }^{1}$ 松本 雅子 ${ }^{1}$ 、國井 葉 ${ }^{1} 、$ 吉原 愛 ${ }^{1}$ 、渡邊 奈津子 ${ }^{1}$ 、服部 尚樹 ${ }^{2}$ 、吉村 弘 $^{1}$ 、杉野 公則 ${ }^{1}$ 、

伊藤 公一

${ }^{1}$ 伊藤病院、 ${ }^{2}$ 立命館大学薬学部

【背景】マクロTSH血症では臨床症状を欠くことが特徵とされるが、潜在性 甲状腺機能低下症でも無症状例は多く、症状の有無によりマクロTSH血症を 疑うことは容易ではない。このため、マクロTSH 血症報告症例と未治療橋本 病症例における予湘TSH值との乘離について解析し、マクロTSH血症の診 断の参考となるか検討した。【対象と方法】コントロール群 (C 群) として2013 年 1 月から 6 月に当院へ初診した未治療橋本病の内、顕性甲状腺機能低下症 を除外した 1559 例 [年齢中央值 40歳(範囲11-87)、男女比1:27] 用い、 $\mathrm{FT}_{4}$ とTSHの関係を多項式にあてはめて $\mathrm{FT}_{4}$ から予測されるTSH值(予測 TSH 值)を求めた。報告例 31 例と当院経験例 1 例をマクロ TSH 血症群(M 群) とし て用い、実測 TSH值と予測TSHを比較した。【結果】C群から、TSH予測 式:TSH $=6.3004073-3.168156 \times \mathrm{FT} 4+15.58633 \times\left(\mathrm{FT}_{4}-1.17098\right)^{2}-80.551289 \times$ $\left(\mathrm{FT}_{4}-1.17098\right)^{3}+23.77637 \times\left(\mathrm{FT}_{4}-1.17098\right)^{4}$ が得られた。M群のTSH值は予測 $\mathrm{TSH}$ に比較し中央值 $11.4 \mu \mathrm{IU} / \mathrm{ml}$ (範囲 4.05-716) と 3.7 倍高值で、32例中 17 例 (53\%)で95\%信頼区間をはずれ高値を呈した。TSH区分別のマクロTSH 血 症の頻度はTSH值 $(\mu \mathrm{IU} / \mathrm{ml})$ により 0.2-2.5.0/848(0\%)、2.51-4.5.1/413(0.2\%)、 $4.51-10.0: 13 / 261(4.7 \%) 、 10.1-20.0: 8 / 70(10.3 \%) 、 21.1-30.0: 4 / 17(19.1 \%) 、 30.1$ 40.0:3/12(25\%)、40.1 以上:3/62(4.8\%)で、TSHが上昇するにつれ高くなる傾向を みとめた。【結語】 $\mathrm{FT}_{4}$ 值から予測されるTSH值を超えたTSH異常高值はマ クロ TSH 血症の診断の一助となる可能性が考えられる。

\section{2-4-29 ラトケ囊胞手術に伴う下垂体機能障害}

木下 康之 、田口 慧 ${ }^{1}$ 、富永 篤 ${ }^{2}$ 、迫口 哲彦 ${ }^{2}$ 、有田 和德 ${ }^{3} 、$ 栗栖 薰 ${ }^{1}$

${ }^{1}$ 広島大学大学院医系科学研究科 脳神経外科学、 ${ }^{2}$ 県立広島病院 脳神経外 科・脳血管内治療科、 ${ }^{3}$ 出水郡医師会広域医療センター脳神経外科

【背景と目的】ラトケ囊胞壁の摘出は下垂体機能障害を引き起こすため、部分 摘出あるいは生検にとどめることが一般的である。それでも術後下垂体機能障 害を生じることがあり、本研究ではラトケ囊胞の手術に伴う下垂体機能障害の 頻度を明らかにすることを目的とした。

【対象と方法】2000年以降に初回手術を行ったラトケ囊胞 94 例を対象とした。 男性 38例、女性56例、平均49.7歳(10-81歳)、追跡期間は平均 69 ヶ月。手術 は囊胞壁の部分摘出あるいは生検、霊胞内の洗浄、鞍上槽または蝶形骨洞への 造㾇術を組み合わせて行った。手術前後のホルモン補充 (副腎皮質/甲状腺/抗 利尿ホルモン) と重症 $\mathrm{GH}$ 分泌不全症( $\mathrm{sGHD}$ )の頻度について検討し、下垂体機 能悪化を予測する因子 (年齢、性別、MR所見、手術手技、病理所見) も検討 した。

【結果】術後に新たなホルモン補充を必要とした症例(機能悪化例) は9例 (9.6\%) であった。一方、sGHDの頻度は術前 $35.4 \%$ 、術後 $24.4 \%$ であり、術前 sGHD 患者の $41 \%$ で術後に回復が認められた。機能悪化例には、術前からホルモン 補充を必要とし術後に上乗せされた 3 例、初回手術後も再手術を繰り返した難 治な 2 例、黄色肉芽腫の病理所見も伴った 1 例、そして思い当たる原因なく術 後新たな補充を必要とした 3 例であった。術後の機能悪化例の予測因子とし て、病理所見に打ける囊胞壁上皮の多層化・扁平上皮化生が挙げられた

【結語】ラトケ囊胞の病態は多彩で、手術により sGHDが回復するような症例 と術後新たにホルモン補充を必要とするような症例が混在する。ラトケ囊胞術 後に新たなホルモン補充を必要とする症例は少なくないことに注意する必要が ある。

\section{2-4-3136年の長期を経て低Na血症を契機に診断に至っ たSheehan症候群の 1 例}

北村 拓也、和田 直樹、上羽 瑶子、湯川 弘、金井 有吾、

森 栄作、米光 新、武呂 誠司

大阪赤十字病院 糖尿病 · 内分泌内科

【症例】63歳女性【臨床経過】X-36年に帝王切開施行し、分婏時の出血量は 中等度であった。その後無月経が継続し、授乳も不可能であった。X-1 ケ月に 癒着性イレウスで外科入院中に倦总感やふらつきが出現した。 $\mathrm{Na} 112 \mathrm{mEq} / \mathrm{L}$ と低值であり、血中コルチゾール $3.19 \mu \mathrm{g} / \mathrm{dL} 、 \mathrm{ACTH} 29.6 \mathrm{pg} / \mathrm{mL}$ と副腎皮質 機能低下が疑われた。精查でfT4 $0.54 \mathrm{ng} / \mathrm{dL}$ 、TSH $1.61 \mu \mathrm{IU} / \mathrm{mL} 、 \mathrm{IGF}-1$ 感度 以下、LH $1.2 \mathrm{mIU} / \mathrm{mL} 、$ FSH $6.1 \mathrm{mIU} / \mathrm{mL} 、 \mathrm{E} 2$ 感度以下と汎下垂体機能低下 が疑われた。視床下部ホルモン4者負荷試験及びGHRP-2負荷試験でいずれも 反応不良であり、汎下垂体機能低下症と診断した。頭部MRI検査では empty sellaの所見であった。病歴から出産時発症したSheehan 症候群に伴うものと 判断した。迅速 ACTH負荷試験ではコルチゾール前值 $4.91 \mu \mathrm{g} / \mathrm{dL}$ 、頂值 10.7 $\mu \mathrm{g} / \mathrm{dL}$ と前值の 2 倍に増加し、 24 時間尿中コルチゾールは $17.8 \mu \mathrm{g} / \mathrm{day}$ と比 較的 ACTH-コルチゾール系は保たれていた。ヒドロコルチゾンの先行補充の 後、レボチロキシンナトリウムの内服で速やかに症状は改善した。推定発症 36 年を経て低 $\mathrm{Na}$ で顕在化した稀な症例を経験したので、若干の文献的考察を 加えて報告する。

\section{2-4-28 神経学的には無症候だが内分泌障害を来たす下垂 体腺腫}

押野 悟 ${ }^{1}$ 、齋藤 洋一 ${ }^{2}$ 、向井 康祐 ${ }^{3}$ 、大月 道夫 ${ }^{3}$ 、梅原 徹 ${ }^{1} 、$ 木下 学 ${ }^{1}$ 、貴島 晴彦 ${ }^{1}$

${ }^{1}$ 大阪大学大学院 医学系研究科 脳神経外科学、 ${ }^{2}$ 大阪大学大学院 医学系研究 科 脳神経機能再生学、 ${ }^{3}$ 大阪大学大学院 医学系研究科 内分泌 ·代謝内科学

【目的】非機能性下垂体腺腫(NF)で視野障害等の自覚症状の有無や、画像での 視交叉圧排の程度が手術適応の基準となる。しかし、視交叉圧排もない腺腫な のに下垂体機能不全で発症する例に遭遇することがあり、早期の手術でそれら が予防できるなら新たな治療指標になりうる。本研究では神経学的に無症候で も下垂体機能、特に副腎系の障害を来した腺腫の特徴について検討した。

【対象】2011年から2019年3月までに当科を受診した下垂体腺腫517例中、NF 初発の手術150例と経過観察となったマクロNF66例を対象とした。視覚の 自覚症状の有無で症候性か否かを定義した。術前評価の結果、ヒドロコルチ ゾン $(\mathrm{F})$ が処方された例 (シックデイ頓用含む)を $\mathrm{F}$ 群とし、視交叉圧排有無や Knosp Grade(KG 0-4) との関連を検討した。

【結果】 F群は症候例の $40 \%(32 / 81$ 例 $) 、$ 無症候例の $28 \%(19 / 69)$ にみられ頻 度に有意差はなかった。手術例の $\mathrm{F}$ 群と非 $\mathrm{F}$ 群では年齢や視交叉压排には差が なかったが、 $\mathrm{KG}$ はF群で有意に低く $(\mathrm{P}<0.01)$ 、無症候例でのF群には KG4は いなかった。経過観察した66例中 11 例がF群、11例がKG4だったが、F群で KG4は 1 例のみだった。手術例のうち無症候で F 群だった 19 例中 5 例 $(26 \%)$ で 補充が不要となった。

【結論】神経症状を呈さない程度のNFでも副腎機能低下例が一定数存在した。 このタイプは海綿静脈洞への進展がなく、腫瘍が拡がらない分、逆に正常下垂 体への圧迫が強かったと推測される。術後に機能回復する例もあり、これらに 対しては下垂体機能低下が悪化する前に積極的な外科治療を考慮してもよいと 考える。

\section{2-4-30 インスリン負荷試験時のインスリン投与量に関す る検討}

鬼頭 健一 ${ }^{1}$ 、永井 聡 ${ }^{1}$ 重沢 郁美 ${ }^{2}$ 、半田 喬久 ${ }^{1} 、$ 枝川 幸子 ${ }^{1}$ 、 北尾 直之 ${ }^{3}$ 、吉岡 成人 ${ }^{1}$

${ }^{1} \mathrm{NTT}$ 東日本札幌病院 糖尿病内分泌内科、 ${ }^{2}$ 北海道大学病院 内科 $2 、{ }^{3}$ 滝川市 立病院 内科

【目的】インスリン負荷試験(ITT) はGHならびにACTH系の標準検查として 広く行われているが, 低血糖を来さず不成功となることがある. その原因にイ ンスリン抵抗性が関与し，不成功にHOMA-R高值が独立因子として報告され ている. 我々はITT 時のIns投与量の決定にHOMA-R を用い, Ins 投与量(IU) = HOMA-Rx0.1x患者体重 $(\mathrm{kg})$ とした場合の試験成功率を報告したが 十分な 成功率とは言えなかった。今回Ins投与量 $(\mathrm{IU})=$ HOMA-Rx0.15x患者体重 $(\mathrm{kg})$ [0.15 群] とした場合について, 試験成功率をIns投与量 (IU) = HOMA-Rx0.1x患 者体重 $(\mathrm{kg})[0.1$ 群]の場合と比較検討したので, 報告する.【方法】対象は 2017 年 4 月から 2019年11月に当科で下垂体疾患が疑われITTを行い, Ins 投与量の決 定にHOMA-Rを用いた 29 名. インスリン投与前, 15 分. 30 分 45 分, 60 分. 90 分, 120 分で血糖測定を行い, 試験成功は血糖 $45 \mathrm{mg} / \mathrm{dL}$ 以下とた。試験成功率を 患者の背景因子で調整し, 比較検討した。【結果】年齢は $49 \pm 14$ 歳, 男性 11 名 女性18名, 体重 $66.1 \pm 19.8 \mathrm{~kg}$, BMI は $25.4 \pm 6.0 \mathrm{~kg} / \mathrm{m} 2$ であった. HOMA-R は $1.6 \pm 1.4$, nadirの血糖は $42 \pm 7 \mathrm{mg} / \mathrm{dL}$ でり, 試験成功は[0.1群] vs. [0.15] 群で13例 (68.4\%)vs. 9例 (90\%) と有意に[0.15群]で高值であった，全例でITTに よる合併症は認めなかった。【結語】HOMA-Rを用いたIns投与量の決定に関 し, 投与量 $(\mathrm{IU})=$ HOMA-Rx $0.15 x$ 患者体重 $(\mathrm{kg})$ でより高い試験成功率を得る ことができた。

\section{2-4-32 原発性先天性甲状腺機能低下症の経過中に視床下 部障害の合併が判明し、診断に苦慮した女児例}

阿部 裕樹 ${ }^{1}$ 、長崎 啓祐 ${ }^{2}$ 、泉田 侑恵 ${ }^{1}$ 、塚野 真也 ${ }^{1}$ 新潟市民病院 小巟科、 ${ }^{2}$ 新潟大学医歯学総合病院 小児科

【目的】

先天性甲状腺機能低下症の多くは原発性であり TSH は高值を呈するが、中枢性 の場合にはTSHはやや高値から低值をとる。原発性と診断した先天性甲状腺機 能低下症の女児で、経過中に視床下部障害が明らかとなり、中枢性との鑑別に 苦慮した症例を経験した。診断時の free T4 と TSHを検討することで、当初か ら視床下部障害の合併を想起できた可能性があり、示唆に富むため報告する。 【症例】

現在 13 歳の女児。マススクリーニングでTSH高値を指摘。free $\mathrm{T} 4<0.10 \mathrm{ng} / \mathrm{dL}$ $\mathrm{TSH} 131.95 \mu \mathrm{IU} / \mathrm{mL}, \mathrm{Tg} \geqq 800 \mathrm{ng} / \mathrm{mL}$, エコーで正所性にやや腫大した甲状腺を 認め、ホルモン合成障害による先天性甲状腺機能低下症と考えた。レボチロキ シンナトリウム補充を開始し甲状腺機能は正常化したが、経過中に発達障害や 肥満が出現。11歳頃から成長率が低下し、負荷試験にて成長ホルモン完全欠損 を認めた。TRH負荷ではTSHは30分, 60分值がそれぞれ149.022, $157.304 \mu \mathrm{IU} /$ $\mathrm{mL}$ 過大反応で、わずかだが遷延傾向であった。頭部 MRIで正常下垂体の描 出がなく、検查結果と併せて視床下部障害による下垂体ホルモン分泌不全と診 断した。診断時のTSHは高值であったが、新潟県のマススクリーニングデー ターと比較したところ、free T4に比してTSHは低值であり、診断時から中枢 性の要素を伴っていた可能性があると考えられた。一方でサイログロブリン高 值、甲状腺腫大などの所見は原発性を示唆しており、両者の病態を合併してい る可能性がある。

【結論】

原発性と視床下部性の要素を合併したと考えられる先天性甲状腺機能低下症の 症例を経験した。診断時にfree T4に対するTSHに注目することで、視床下部 性甲状腺機能低下症の合併を想起できた可能性がある。 
02-4-33 トラマドールにより視床下部性ACTH分泌低下症 が顕性化した神経線維腫症 1 型の一例

綿貫 裕、竹内 祐貴、藤田 朋之、山形 聡、高安 忍 䔖山 和則、大門 眞

弘前大学医学部附属病院 内分泌代謝内科

【症例】41歳女性。15歳時に神経線維腫症1型（NF1）の診断。X-3年頃より 日中の倦急感を訴えていた。同症状精查のためX年 4 月当院総合診療部を受 診。ACTH $13 \mathrm{pg} / \mathrm{mL}$ 、Cortisol (F) $2.6 \mu \mathrm{g} / \mathrm{dL}$ 、好酸球增多 (11\%) も伴っ ていたため精查目的に当科紹介入院。CRH testでACTHは過大反応（頂値 87）するものの F 頂値は 8.0 と低值だった。ACTH 以外の下垂体前葉機能低下 は無く、ITTではACTH/Fの上昇が確認されない（頂值 12/7.7）ことから視 床下部性の ACTH 単独欠損が疑われた。頭部 MRIでは視床下部、下金体周囲 に異常所見は確認されなかった。視床下部障害の原因として、NF1関連の背 部痛に対して麻醉科から長期的に処方されていたトラマドールのオピオイド $\mu$ 受容体を介した視床下部一下垂体一副腎（HPA）系への抑制的な影響が考元 られた。同郕を漱減中止した 2 日後の採血では、ACTH/F = 35/18.3 といずれ も上昇が確認された。薬剂中止後に倦急感は有意に軽快し、背部痛も增悪は 見られなかった。中止後約1 ケ月で再検したCRH testでは初回と比べACTH/ $\mathrm{F}$ 基礎值 11/6.2、頂值48/14.2 と ACTH過大反応の消失と $\Delta \mathrm{F}$ の增加が確認さ れた。【考察】オピオイド系鎮痛薬による続発性副督不全の報告は散見される が、経時的に複数回の負荷試験でその回復過程を観察し得た報告は無い。また in vivoでの検討で、NF1では Neurofibrominの機能䘫失による紐胞内cAMPレ ベルの低下を介しHPA系機能低下を来すという病態が報告されている。以上 より本症例はNF1による (不顕性) 視床下部性下垂体機能低下を背景にオピ オイド系薬剤による薬剂性視床下部機能低下が合併したため顕性化した教育的 な病態と考えられたため報告する。

\section{2-4-35 Adult-onset ゴナドトロピン単独欠損症の検査結 果を呈した男性摂食障害患者の一例}

大岩 亜子、福嶋 海、柴田 有亮、山崎 雅則、駒津 光久 信州大学 医学部 附属病院 糖尿病・内分泌代謝内科

【症例】18歳男性、BMI $15.2 \mathrm{~kg} / \mathrm{m}^{2}$ 。約 2 年前から食事摂取不良になり体重が 1 年で $21 \mathrm{~kg}$ 減少、体力低下で通学困難になり精神科を受診した。精神科では慢 性疲労症候群と診断されるも、採血にてテストステロン低値を認めたため当院 一紹介。二次性徴は問題なし。 LH $0.2 \mathrm{mIU} / \mathrm{mL}$ と FSH $0.6 \mathrm{mIU} / \mathrm{mL}$ 、フリーテ ストステロン $0.9 \mathrm{pg} / \mathrm{mL}$ と項目とも著明低值を認め二次性性腺機能低下症が 疑われた。垂体造影MRIでは異常なし。LHRH連続負荷検查ではLH分泌能 は改善せず、adult-onsetのゴナドトロピン単独欠損症が強く疑われ、hCG 皮 下注射を少量で開始した。しかしフリーテストステロンは速やかに上昇する 一方で、さらなる体重隇少を呈したためhCG治療は約 3 个月で中止した。その 後、自身の日記に体重增加への恐れを示す記載を看護師が発見し、それを契機 に精神科にて䀧食障害と診断。摄食障害の治療を開始したところ、体重は半 年で $15 \mathrm{~kg}$ 増加し、フリーテストステロン基碟值は $13.9 \mathrm{pg} / \mathrm{mL}$ と基準值内へ改 善。さらにLHRH 負荷梌查でも LHと FSH は正常反応に改善L、LH・FSH · フリーテストステロン著明低值とやせの原因は、掑食障害であったことが判明 した

【考察】当症例の男性掑食障害患者に执いて、LH・FSH・フリーテストステロ ンの基碟值が掑食障害患者に打ける既報デー夕に比して著明低值を示し、さら にLHRH 連続負荷検查にて下垂体障害パターンを認め、Adult-onset ゴナドト ロピン単独欠損症が強く疑われる検查結果を呈した摂食障害患者とゴナドト ロピン単独欠損症の鑑別は検查值からでは困難であり、まずは掑食障害を積極 的に疑うこと、さらに掑食障害患者に扔けるホルモン検査結果の多様性を認識 することが重要であると思われた。

\section{2-6-1 核内オーファン受容体COUP-TIIのTNF- $\alpha$ 抑制 を介した急性腎障害における腎保護作用}

石井 角保 ${ }^{1} 、 山$ 正信 ${ }^{2}$ 、鯉淵 典之

${ }^{1}$ 群馬大学大学院 医学系研究科 応用生理学分野、 ${ }^{2}$ 群馬大学大学院 医学系研 究科 内分泌代謝内科学

【背景】核内オーファン受容体であるChicken Ovalbumin Upstream Promoter Transcription Factor II (COUP-TFII)のノックアウト(KO) マウスは胎生致 死だが、成体特異的KOマウスは明らかな障害を認めない。しかし、COUPTFIIが成体期の様々な病態において機能することが明らかとなってきた。今 回、急性㹂障害における COUP-TFIIの役割を検討した。【方法】 1) 㹂䐟に おける COUP-TFIIの mRNA レベルを多臟器と比較した。2) シスプラチン投 与による急性腎障害誘発の前後でCOUP-TFIIの発現を免疫染色で確認した。 3）COUP-TFII成体KOマウスに扔いて急性腎障害を誘発し、血清クレアチ ニン $(\mathrm{Cr})$ 值やTUNELアッセイを用いて重症度を検討した。4）血中および腎 組織中のTNF- $a$ を湘定した。5）COUP-TFIIによるTNF- $a$ 抑制機構を培 養細胞に扔けるノックダウンとクロマチン免疫沈降法で検討した。【結果】1） COUP-TFIIは腎臟において高発現していた。2) COUP-TFIIは遠位尿細管細 胞と間質綀胞に発現しており、急性腎障害誘発によって発現量は低下した。3) COUP-TFII成体KOマウスにおいて対照マウスに比べてCr高值、TUNEL陽 性細胞の増加を認め、㹂障害が重症化していた。4）TNFー $a$ はKOマウスにお いて高值であった。5）COUP-TFIIはTNF- $a$ 遺伝子周辺の保存された結合配 列領域に結合しており、転写抑制作用が示唆された。結語】COUP-TFII TNF- $a$ 遺伝子転写抑制による腎保護作用があり、急性督障害の治療標的分子 となりうる。

\section{2-4-34 うつ病、身体症状症などで通院中に特発性食後症 候群様症状を訴えた患者の視床下部一下垂体一副 腎軸について}

松林 直、中武 伸元、有満 啓史、原 健 福岡德洲会病院 心療内科・内分泌科

【目的】特発性食後症候群(IPS) は食後低血糖と関連するといわれている，副㹂 皮質機能との関係が取り沙汰されているもののいまだ明らかではない【対象 と方法】食後に不快な症状を呈するいわゆるIPS様症状を訴えたうつ病, 身体 症状症, パニック障害, 慢性疲労症候群などで心療内科通院中の 14 名 (男性 5 名, 年齢中央值 35 歳) $2250 \mu \mathrm{g}$-CORTROSYN (ACTH) 試験, CRH 試験, インスリン低血糖試験（ITT）を実施した。な拉，ITTは最低血糖値 $<45 \mathrm{mg}$ dLを採用した【結果】コルチゾール基礎值 $72 \pm 36 \mu \mathrm{g} / \mathrm{dL}$ コルチゾール 基碟值 $<4 \mu \mathrm{g} / \mathrm{dL}$ は1 名, 基準値 $(6.24-18.0 \mu \mathrm{g} / \mathrm{dL})$ 末満は 9 名であった。 $\mathrm{ACTH}$ 基碟值 $20.2 \pm 21.1 \mathrm{pg} / \mathrm{mL}$. ACTH 基準値（7.2-63.3pg/mL）未満は2名 にみられた. ACTH試験, CRH 試験, ITTのコルチゾール頂値 $<18 \mu \mathrm{g} / \mathrm{dL}$ の割合は ACTH 試験 14 名中 4 名 $(28.5 \%), \mathrm{CRH}$ 試験 14 名中 12 名 $(85.7 \%)$, ITT10名中 10 名 $(100 \%)$ と割合は異なったACTH試験のコルチゾール頂值 と CRH 試験のコルチゾール頂值はよく相関（F=43.2024，r=0.0002）したが， ITTのコルチゾール頂値とは相関 $(\mathrm{F}=2.8068, \mathrm{r}=0.1324)$ しなかった. CRH 試験, ITTの ACTH 頂值/基礎值比はそれぞれ $4.0 \pm 2.0,3.4 \pm 2.0$ であり，2 倍 未满の ACTH 分泌低下症を疑わせる患者はそれぞれ 1 名 $(7.1 \%) 、 2$ 名 $(20 \%)$ であった、結語】IPS様症状を訴えた心療内科通院中患者は視床下部一下垂 体一副腎軸検查から中枢性副腎皮質機能低下症の存在が伺われた。な拉、広く 用いられている副㻉皮質機能低下症診断アルゴリズムに合致しない例が多くみ られた

\section{2-4-36 47,XXYでSHOX遺伝子3コピーを認めたにも関 わらず低身長を呈したフラインフェルター症候群 の 1 例}

稲見 光浩 ${ }^{1}$ 、稲垣 早織 ${ }^{2} 、$ 吉田 里穂 ${ }^{2}$ 宮原 弥恵 ${ }^{2}$ 、龟井 望 ${ }^{2}$ ${ }^{1}$ 広島赤十字・原爆病院 臨床研修部、 ${ }^{2}$ 広島赤十字 $\cdot$ 原爆病院 内分泌 ·代謝 内科

【背景】性染色体短腕には成長に関わるSHOX（short stature homeobox）遺 伝子が存在し、正常な発育には2 2 コ゚ーが必要とされる。クラインフェル夕ー 症候群 $(47, \mathrm{XXY})$ では、これを3コピー認めるため、思春期前から高身長を 示し標隻成長曲線のお上そ+1SD となることが知られている。今回我々は、標 準身長曲線の-3SDの低身長を呈したクラインフェルター症候群を経験したの で報告する。【症例】21歳、男性。11歳までは身長の伸びは正常であったが、 13 歳で-2SD となり、その後も成長は停滞していた。20歳時に二次性徴の遅れ を主訴に近医を受診し、当院を紹介され受診。身長 $158.7 \mathrm{~cm}(-3 \mathrm{SD})$ 、指極長 $160.0 \mathrm{~cm}$ 、陰毛と腋毛は少量で、両側精巣の低形成とEmpty sellaを認めた。 GH $0.55 \mathrm{ng} / \mathrm{ml}$ IGF-I $69 \mathrm{ng} / \mathrm{ml}$ であり、GH分泌不全性低身長症を疑ったが、 GHRH 試験、アルギニン試験、GHRP-2 試験、インスリン低血糖試験はいずれ も正常反応であった。また、LH $5.54 \mathrm{mIU} / \mathrm{ml} 、$ FSH $8.63 \mathrm{mIU} / \mathrm{ml}$ 、テストス テロン $0.23 \mathrm{ng} / \mathrm{ml}$ であり、LHRH 試験と連続 LHRH 試験の低反応、hCG 試験正 常反応から、下垂体性性腺機能低下症と診断した。染色体検查で $47, \mathrm{XXY}$ を認 め、FISH法によりSHOX連伝子を3コピー認めた。考察】SHOX連伝子の欠 失を認めないにも関わらず低身長になった原因として、1.負荷試験では正常て あったもののIGF-Iが低値であったこと、2.性腺機能低下のため第二次性徵が なく思春期成長スパートが遅れたこと、の2点が関与したと考えた。

\section{2-6-2 ゼブラフィッシュを用いた、眽波と心電測定およ びICG 動脈硬化巣ライブイメージングによる総合 的糖尿病合併症評価法}

\author{
伊藤 太二 ${ }^{1,2}$ 、菅原 沙恵子 ${ }^{1}$ 、櫻井 浩平 ${ }^{1} 、$ 相田 萌花 $^{1} 、$

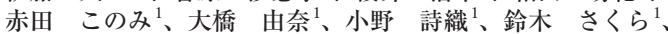 \\ 中谷 桃子 ${ }^{1}$ 、酒造 麻実 $^{1}$ 、三村 明穂 $^{1}$ 、大村 正史 $^{1}$ 、高橋 君子 ${ }^{1}$ 、 \\ 中谷 弥栄子
}

鎌倉女子大学 家政学部 管理栄養学科、 ${ }^{2}$ 国立病院機構 横浜医療センター

【目的】ゼブラフィッシュは糖尿病合併症モデル候補であるが、動脈硬化や自 律神経障害等の総合的評価システムが存在しない。そこで本研究では、ゼブラ フィッシュを用いた脈波と心電測定およびICG 動脈硬化巣ライブイメージング による総合的糖尿病合併症評価法を確立することを目的とした。

【方法と結果】まず、高脂質食摂取で肥満モデルを作出し、空腹時血糖の有意 な増加を認めた。次に、ヒト用光電脈波センサーを超小型化したゼブラフィッ シュ専用センサーを設計し加速度脈波を取得したところ、高脂質食群では普 通食群に比べ加速度脈波加齢指数が有意に上昇し、動脈硬化発症が示唆され た。並行して、小型 $\mathrm{Ag} / \mathrm{AgCl}$ 電極を設計しバイオアンプと組み合わせ非侵 龍での心電を湘定したところ、高脂質食群では、心虚血と考えられる異常波形 やQTc 間隔の短縮が惹起された。さらに、励起・蛍光波長が第一生体空に位 置するICGに着目し、これを背側大動脈に注入して、経時的に蛍光動画造影し た。その結果、高脂質食群では普通食群に比べ、動脈硬化巣と考えられる特 定部位が高 $\mathrm{S} / \mathrm{N}$ 比で検出された。一方、心電図の $\mathrm{R}-\mathrm{R}$ 間隔のゆらぎに注目し CVR-Rとパワースペクトル解析を行ったところ、CVR-Rでは有意な変化は見 られなかったが、パワースペクトル解析で、高脂質食群では初期の自律神経障 害と考えられる副交感神経の有意な活動低下が認められた

【結論】ゼブラフィッシュは、糖尿病合併症を迅速かつ高感度で総合的に評価 できる極めて有用な疾患モデルである。 


\section{2-6-3ケトン体による脂肪細胞機能制御}

西谷 重紀、福原 淳範、申 智勲、奥野 陽亮、大月 道夫、 下村 伊一郎

大阪大学大学院医学系研究科 内分泌 - 代謝内科学

【背景】SGLT2 阻害郕は血中ケトン体の増加作用が報告されているがケトン体 の脂肪組織への作用は明らかでない。【目的】ケトン体の脂肪組織への作用を 明らかにすること。【方法・結果】コントロール群(KK 早)、肥満・糖尿病群 (KKAy o )、SGLT2 阻害郕投与群(KKAy 早にダパグリフロジン飲水投与)の 3 群を自由提餌・飲水で5週間観察し卵巣周囲脂肪組織のメタボローム解析・マ イクロアレイ解析を施行した。結果、肥満・糖尿病群と比較LSGLT2 阻害剂

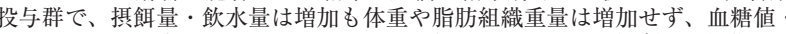
$\mathrm{HbAlc}$ の上昇は抑制、血中インスリンは低下しインスリン感受性が立進、血 中のアデイポネクチンと3-ヒドロキシ酪酸 (3HBA) は有意ではないものの増加 した。卵峃周囲脂肪組織のメタボローム解析では3HBAが上昇、マイクロア 亿解析では $3 \mathrm{HBA}$ の取り込み輸送体や代謝䣼素・アディポネクチン・脂肪合成 関連の遺伝子発現は増加傾向、炎症性因子の遺伝子発現は低下傾向を認めた。 3T3-L1脂肪細胞への 3HBA 添加でアディポネクチンは遺伝子発現・細胞内夕 ンパク、ヒストンの $\beta$-hydroxybutyrylationが増加し、同時にインスリン感受 性が充進しインスリンシグナル関連タンパクと下流の脂肪合成関連の遺伝子発 現が増加した。C57BL/6J たを絶食後、再摄食開始時に3HBAを投与すると精 巣周囲脂肪組織の脂肪合成関連の遗伝子発現が増加した。さらに3T3-L1脂肪 細胞の分化過程で分化初期から $3 \mathrm{HBA}$ 合成䣼素の遺伝子発現が上昇した。以上 より脂肪組織に扔けるケトン体のアディポネクチン発現増強作用とインスリン 誘導性の脂肪酸合成促進作用が示唆され、脂肪細胞自体がケトン体を合成・分 泌しオートクライン・パラクラインにこれらの作用が発揮される可能性を見出 した。

\section{2-6-5 血管內皮細胞由来C型ナトリウム利尿ペプチド (CNP) は腎臟疾患による腎線維化を抑制する}

延生 卓也 ${ }^{1} 、$ 日野 純 ${ }^{1} 、$ 白井 学 $^{3} 、$ 細田 洋司 ${ }^{2}$ 、森 健二 ${ }^{1} 、$ 南野 直人 ${ }^{3}$ 、宮里 幹也 ${ }^{1}$ 、寒川 賢治

${ }^{1}$ 国立循環器病研究センター研究所 生化学部、2 国立循環器病研究センター 研究所 再生医療部、 ${ }^{3}$ 国立循環器病研究センター OIC 創薬オミックス解析 センター

【背景・目的】慢性腎臟病の多くは腎臟間質の線維化・炎症を主体とした病態 である。一方、C型ナトリウム利尿ペプチド $(\mathrm{CNP})$ は、血管内皮細胞 (EC) から主に産生され、炎症や線維化を抑制する。しかし、EC由来 CNPの腎臓疾 患における役割については未だ明らかにされていないるここで㹂臟疾患におけ る CNPの新たな機能解明を目的とし、EC由来のCNPの抗線維化作用に着目 して解析を行った。

【方法・結果】12週齢マウスに片側性尿管結紮（UUO）を施し、間質線維化モ デルを作製した。UUO後の腎臟血管内皮細胞においてCNP mRNA発現の顕 著な上昇が認められたことより、EC特異的 CNP過㮃発現マウス $(\mathrm{Tg})$ を用 いて腎臓間質線維化に対する作用を検討した。その結果、Tgにおいて野生型 マウスと比較してUUO 後4日抢よび7日の腎臓皮質の線維化（シリウスレッ ド染色陽性領域）の抑制に加え、腎蔵における線維化マーカー遺伝子の発現抑 制が認められた。この作用機序解明の為、UUO後の腎臟皮質領域のRNA-seq 解析を行ったところ、Tgに扔いて細胞増殖に関連する因子群の発現が抑制さ れ、CNPによる線維芽細胞の増殖抑制作用が示唆された。そこで、線維芽細 胞を腎臓皮質から調製し解析すると、CNP依存性のcGMP産生立進、VASP 活性化を示した

【結論】EC由来CNPが腎臓の線維化を抑制する事が明らかとなった。これら の結果は血管内皮細胞が腎臓疾患の病態に深く関与する事に加え、CNPが腎 臟疾患に対する新たな治療薬の標的となる可能性を示している。

\section{2-6-8＼cjkstart関節リウマチ患者における血清アディポネクチン 值と体組成の疾患活動度・治療抵抗性指標として の有用性の検討}

南野 寛人 ${ }^{1,2}$ 、藤田 義人 ${ }^{1}$ 勝島 將夫 ${ }^{3,4}$ 、橋本 求 $^{4}$ 、吉田 玉美 $^{5}$ 白柏 魅怜 ${ }^{3,4}$ 、村上 孝作 ${ }^{4}$ 、村田 浩一 ${ }^{4}$ 、西谷 江平 $^{4}$ 、田中 真生 ${ }^{4} 、$ 伊藤 宣 ${ }^{4}$ 、稲垣 暢也 ${ }^{1}$

京都大学大学院 医学研究科 糖尿病内分泌栄養内科学、 ${ }^{2}$ 日本学術振興会特 別研究員 DC、 3 京都大学大学院医学研究科 内科学講座臨床免疫学、 4 京都大 学大学院 医学研究科 リウマチ性疾患先進医療学、5 京都府立医科大学 医学 部看護学講座 老年看護学講座

【背景】関節リウマチ（RA）は関節の炎症・破壊を主体とする疾患で、関節由 来の炎症性メデイエータが体組成に影響するとされる。アデイポネクチンは、 抗動脈硬化作用等を有する生理活性物質として知られるが、RAにおける体組 成や疾患活動度との関連についての報告は少ない。【方法】京都大学りウマチ センターのKURAMAデータベースを用い351名のRA患者を抽出した。血清 アディポネクチンはLTIA法で測定した。体組成はインピーダンス法で測定 し、BMI(cut-off: 18.5 と $25 \mathrm{~kg} / \mathrm{m}^{2}$ ) と内臟脂肪（cut-off: $100 \mathrm{~cm}^{2}$ ) により 5 群に分 けた。疾患活動度はDAS28-ESR（28-Joint RA Disease Activity Score）を用 い、相関する因子を重回帰分析で評価した。【結果】体組成別の検討では、低 体重群で、他の 4 群に比べ血清アディポネクチン $(20.9 \pm 12.5$ vs. $14.7 \pm 8.4 \mu \mathrm{g} /$ $\mathrm{ml}, \mathrm{p}<0.001)$ 及びDAS28-ESR ( $3.04 \pm 1.0$ vs. $2.63 \pm 0.9, \mathrm{p}=0.017)$ が有意に高值で あった。多変量解析ではDAS28-ESRに対し、BMIではなくアディポネクチン 値が有意に正の相関を示した $(\mathrm{p}=0.0258)$ 。生物学的製䬉の使用やその種類はア ディポネクチンに影響しなかった。【結論】血清アディポネクチン值は、治療 抵抗性や疾患活動度の高い低体重群で高值を示した。アディポネクチンはRA 患者のリスク群を拾い上げる、治療内容に影響されない新規の指標として有用 性が示唆された。

\section{2-6-4 脂肪細胞乳酸産生酵素LDHAによる脂質代謝制御}

峰村 友美 ${ }^{1}$ 、福原 淳範 ${ }^{2,3}$ 、大月 道夫 ${ }^{3}$ 、下村 伊一郎 ${ }^{3}$

大阪大学大学院 生命機能研究科、 ${ }^{2}$ 大阪大学大学院 医学系研究科 肥満脂肪 病態学寄附講座、 ${ }^{3}$ 大阪大学大学院 医学系研究科 内分泌 ·代謝内科学

【背景・目的】乳酸が脳以外の組織でTCA回路の基質となることが報告され 乳酸のエネルギー源としての役割が注目されている。一方で非糖尿病者に执 ける検討で血中乳酸值高值群のBMI、HOMA-IRが高く乳酸と肥満・インス リン抵抗性病態との関連が報告されている。しかし乳酸が代謝に与える影響 は不明であり、本研究では脂肪細胞由来乳酸の意義を明らかにすることを目 的とした。方法・結果】1. 脂肪細胞での乳酸産生の制御について、乳酸産生 酵素LDHAの発現は脂肪細胞分化に伴い増加した。またマウス脂肪組織での LDHAの発現と乳酸産生・放出は絶食・再摂食などの栄養状態の変化による 調節を受けた。2. LDHA floxマウスとAdiponectin cre マウスの交配により脂 肪細胞特異的LDHA 欠損（LDHAKO）マウスを作製した。LDHAKOマウス の脂肪組織からの乳酸放出量はLDHAfloxマウスに比べ低下した。LDHAKO マウスは空腹時血中TGが有意に高值であり、oral lipid tolerance testではTG クリアランスの低下を認めた。このとき脂肪組織の LPL活性が LDHAKO マウ スで低下していた。以上より、脂肪細胞LDHAが脂肪組織LPL活性を介して 血中TGを制御することが明らかになった。【考察】絶食・再摂食などの栄養 状態の変化によって、脂肪組織LPL活性が変化することで脂質代謝が制御さ れる。今回の結果から、脂肪細胞が産生した乳酸、もしくは乳酸産生に伴う代 謝性変化が脂肪組織LPL活性を制御することで、全身の脂質代謝を制御する ことが示唆された

\section{2-6-6 都市部地域住民を対象とした血圧と脂質レベル別 組み合わせによる潜在性心不全罹患リスクに関す る研究 : 吹田研究}

小久保 喜弘、東山 綾、渡邊 至、河面 恭子、宮本 恵宏

国立循環器病研究センター 予防健診部

【目的】欧米以外で地域住民を対象とした心不全の追跡研究は殆どない。そ こで、都市部地域住民を対象に血圧と脂質レベル組合せによる潜在性心不全 (LHF)羅患リスクについて検討した。

【方法】ベースライン調査で全対象者にBNPを測定し、BNP $\geqq 100 \mathrm{pg} / \mathrm{mL}$ 、心 不全治療を除外し追跡可能な 2809 名の吹田研究対象者 (平均年齢 $66.7 \pm 10.4$ 歳) を研究対象とした。同一対象者に対して 2 年毎に健診に合わせてBNPも湘定 した。血圧は 2 回測定しその平均值を用いた。収縮期血圧(SBP)を正常血圧 $(<120 \mathrm{mmHg})$ 、高值血圧 $(120-139 \mathrm{mmHg})$ 、高血圧 $(\geqq 140 \mathrm{mmHg}$ 又は降圧剂服 用)に分類した。Non-HDLC は総コレステロールからHDLCを引いた值を用い た。BNPはCLEIA 法で測定し、 $100 \mathrm{pg} / \mathrm{mL}$ 以上または心不全治療を LHF と定 義した。エンドポイントは最後の健診受診日、初回LHF定義日、2018年3月 末の何れかの早い日である。循環器の古典的危険因子で調整されたCox 比例ハ ザードモデルを用いて解析した。

【結果】18,134人年追跡期間中に 335 名のLHFを診断した。LHF罹患の調整 ハザード比 (95\%信頼区間, CI) は、正常血圧群を基準に高血圧群において 1.64 (1.16-2.30)、SBP 20mmHg 当たり 1.18 (1.04-1.34)、Non-HDLC正常值(130$179 \mathrm{~m} / \mathrm{dL})$ 群を基準に、Non-HDLC低値 (<130m $/ \mathrm{dL})$ 群で 1.47 (1.15-1.88)で あった。Non-HDLC正常值でかつ正常血圧群を基準に、LHFの調整ハザー ド比 (95\% CI) は、Non-HDLC 正常值でかつ高血圧群において 1.59 (1.09-2.31)、 Non-HDLC 低值でかつ高值血圧群において1.87 (1.14-3.08)、Non-HDLC低值 でかつ高血圧群において 2.44 (1.64-3.63)であった。

【結語】都市部地域住民を対象に我が国で初めて、高血圧、Non-HDLC 低值が LHDの罹患リスクであった。

\section{2-6-9 後天性脂肪菱縮症の糖脂質代謝異常に対するメト レレプチンとSGLT2阻害薬併用治療の有効性}

永山 綾子、蘆田 健二、渡邊 美希、赤須 祥子、原 健人、 鶴田 宗久、和田 暢彦、野村 政壽 久留米大学内分泌代謝内科

【背景】メトレレプチン (Mlept) 補充療法は、先天性脂肪萎縮症における難治 性かつ高度の脂質・糖代謝障害を改善する。しかし血中レプチン濃度が基準 值の不全型脂肪萎縮症に対するMlept投与の効果は明らかでない。今回、小 児期に造血幹細胞移植を契機とする後天性脂肪萎縮性糖尿病の症例を経験し た。【症例】24歳女性。3歳時に急性リンパ性白血病に対して化学療法と全身 放射線照射後に同種幹細胞移植を受けた。11歳時に高中性脂肪(TG) 血症掞よ び糖尿病と高度のインスリン抵抗性を指摘された。BMI $15.4 \mathrm{~kg} / \mathrm{m}^{2}$ 。体幹、 四肢ともに皮下脂肪の減少を認めた。FPG $145 \mathrm{mg} / \mathrm{dL}, \mathrm{HbA} 1 \mathrm{c} 9.6 \%$, FCPR $3.96 \mathrm{ng} / \mathrm{dL}$ 。肝臓の Proton Density Fat fraction (MRI) は22\%と高值であり、 euglycemic-hyper insulinemic clamp法では $2.1 \mathrm{mg} / \mathrm{kg} / \mathrm{BW} / \mathrm{min}$ と高度のイ ンスリン抵抗性が示唆された。【結果】血中レプチン濃度は $10 \mathrm{ng} / \mathrm{mL}$ と正常 下限值でアディポネクチン濃度は $0.3 \mu \mathrm{g} / \mathrm{mL}$ と低值であり全身放射線照射に 起因する後天性脂肪萎縮症と診断し Mlept 開始した。治療開始後1ヶ月で高 TG 血症やインスリン抵抗性が改善した。SGLT2 阻害薬の追加により糖尿病は さらに改善した【考察】全身放射線照射はChildhood cancer survivor (CCS) の脂肪萎縮症発症と関連する。またCCSは耐糖能障害や脂質異常症を高率に 発症し、心血管疾患の合併は重要な予後規定因子である。本症例の治療経過か ら後天性脂肪萎縮性糖尿病に対するMlept と SGLT2 阻害薬投与の脂質代謝改 善作用と糖代謝改善に対する有効性が示された。【結語】MleptおよびSGLT2 阻害薬が脂質・糖代謝障害の改善に有効であったCCSの一例を提示した。 


\section{2-7-1オートファジーを介したサルコペニアに関与する 新たな調節因子の解明}

山田 英二郎 1 、佐々木 毅志 ${ }^{2} 、$ 中島 康代 1 岡田 秀一 1 、 筑田 博隆、山田 正信

${ }^{1}$ 群馬大学大学院医学系研究科 内分泌代謝内科学、 ${ }^{2}$ 群馬大学大学院医学系 研究科 整形外科学

医学の急速な進歩等に伴い増加倾向である高龄者では生活機能障害を招くサル コペニア(加齢性筋肉減弱症)やフレイル(虚弱)が注目されてきている。サル コペニアの成因として、近年オートファジー (自己領食)調節機構も関与する ことが報告された。我々は近年、非受容体型チロシシキナーゼFynが vps34Atg14-beclin1複合体を介してSTAT3 依存性にオートファジーを調節し、サ ルコペニアに関与する事を報告したしかしこれら検討は主にトランスジェ ニックマウスを用いた非生理的な検討であったため、実際にFynがサルコペ ニアの病態に関与するかどうかの更なる検討を行い次のような結果を得た。 1. マウス $\mathrm{C} 2 \mathrm{C} 12$ 筋管綀胞を用い、サルコペニアの成因に関与するとされている 炎症性サイトカイン刺激した後にFynの既知の夕ーゲットSTAT3のリン酸化 を確認すると、メタボリック症候群にも関与すると考光られるIL6のみでその 上昇を認めた 2 . その上昇はFynをノックダウンした際には用量反応的検討で も、経時的検討でも消失する事を確認した 3 . マウス $\mathrm{C} 2 \mathrm{C} 12$ 筋管細胞に拀いて IL6 依存性にオートファジーの低下が起こり、Fynのノックダウン細胞では再 活性化が起こることを確認した4. 野生型マウスで片足の腓腹神経を切断したし たところ、2週間後には切断肢の各種筋肉量が減少することを確認した5.これ

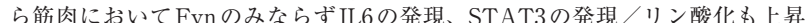
しており、オートファジー活性の低下も認めた。これらの結果はFynがメ夕 ボリック症候群のみならずサルコペニアの成因にも関与している事を示唆して いると思われ、サルコペニア肥满の病態解明、治療法の開発につながる可能性 があると思われる。

\section{2-7-3 一般生化学検查から甲状腺機能異常を予測する人 工知能システムの開発と検証}

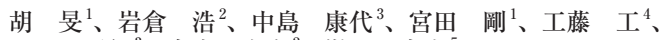
山田 正信 ${ }^{3}$ 、赤水 尚史 ${ }^{2}$ 、榊原 康文

${ }^{1}$ 株式会社コスミックコーポレーション、和歌山県立医科大学附属病院 糖 尿病・内分泌代謝内科、 ${ }^{3}$ 群馬大学医学部附属病院 内分泌糖尿病内科、 ${ }^{4}$ 医 療法人神甲会噮病院 内科、5 慶應義塾大学 理工学部

【背景】本邦に扔ける甲状腺疾患の治療が必要な患者は約 240 万人と推計され る。しかし、実際に治療を受けているのは約 45 万人と報告されており、未治 療の患者が多く存在している。本研究は甲状腺機能異常の見逃しや他の疾患と の誤認を防ぐために、健診検查項目などの一般生化学検查から甲状腺機能異 常を判別する人工知能診断支援システムを開発した。【方法】和歌山県立医科 大学附属病院の電子カルテデータから甲状腺機能充進症、低下症をそれぞれ 7,779 件、5,062 件抽出し、日高会日高病院で健康診断を受けた健常者デー夕と 合わせて、機械学習手法XGBoost 適用し甲状腺機能元進症と低下症をそれ ぞれ判別するモデルを構筑したきモデルの検証として、10分割交差梌証で感 度、特異度、正診率などの指標を求めた。モデルの判別に影響する検查項目を 検証するために、变数重要度を求めた。【成績】甲状腺機能異常判別モデルは 高い精度を示した。学習された光進症の判別モデルの感度、特異度扔よび正診 率は $79.0 \% 、 82.7 \% 、 80.8 \%$ であった。低下症の判別モデルでは $77.7 \% 、 78.3 \%$ 、 $78.0 \%$ であった。モデルの変数重要度を求めた結果、充進症判別に影響する トップ3つの検查項目はALP、赤血球数、性別であり、低下症判別に影響する 項目は赤血球、GOT、ALPであった。【結論】一般検查項目值から甲状腺機能 異常症を判別する人工知能システムを開発し、判別精度を検証した。

\section{2-7-5 グルタミン代謝の破綻はフェロトーシス依存的に 盰癌を増悪させる}

鈴木 佐和子 ${ }^{1,2}$ 、石渡 一樹 ${ }^{1,2}$ 、内藤 久美子 ${ }^{1,2}$ 、出口 ハンナ ${ }^{1,2}$ 、 類家 裕太郎 ${ }^{1,2}$ 、石田 晶子 1,2 、藤本 真德 ${ }^{1,2}$ 、田村 愛 ${ }^{1,2}$ 、 志賀 明菜 ${ }^{1,2}$ 、小出 尚史 ${ }^{1,2}$ 、田中 知明 ${ }^{3}$ 、横手 幸太郎 ${ }^{1,2}$

${ }^{1}$ 千葉大学 医学部附属病院 糖尿病代謝内分泌内科、 ${ }^{2}$ 千葉大学 大学院医学研 究院 内分泌代謝 - 血液・老年内科学、 ${ }^{3}$ 千葉大学 大学院医学研究院 分子病 態解析学

【緒言】グルタミン代謝は糖代謝・TCAサイクル・脂質代謝・アミノ酸代謝 いった様々な代謝経路とクロストークする重要な代謝経路である。我々はク ル夕ミン代謝の master regulatorである Glutaminase2 (GLS2) は好気的エネル ギー産生を正に調整する一方、抗酸化作用を発揮するミトコンドリア遺伝子で あり、癌抑制遺伝子 053 とエネルギー代謝をつなぐ重要な遺伝子であることを 報告してきた【方法】 GLS2を介したグルタミン代謝の破綻が生体内に及ほすす 影響を検討する目的でGls2 ノックアウトマウスを作成し特に生活習慣病と発癌 に焦点を当て解析した。【結果】Gls2 ノックアウトマウスは wild-type と比䡴し て高脂肪食負荷後、糖尿病を発症する一方で、高龄で肝癌を発症した。加えて 肝癌発症モデルマウス（STAMマウス）を用いた検討でも同様に、肝癌が増 悪することを確認した。肝臟 primary cultureを用いた検討でGls2 ノックアウ トマウスにおける䀒癌発症の分子メカニズムの一つとして鉄・脂啠依存的な細 胞死Ferroptosisが関与していることを明らかとしたので詳細な機序を含めて 報告する。 $\underline{02-7-2}$

下垂体機能低下症を併発した本態性高 Na血症の一 例

岸 裕太郎、竹内 亮、山本 正彦、松林 泰弘、山田 貴穂、 岩永 みどり、石黑 創、藤原 和哉、曾根 博仁 新潟大学医歯学総合病院 内分泌・代謝内科

【症例】38歳男性【既往歴】2型糖尿病、脂質異常症、高尿酸血症、脂肪肝 【経渦】25歲の比糖尿病々䛦断されイインスリン強化撚法を道入したが外来で インスリンを離脱し、HbAlc $6 \%$ 程度で推移していた。外来通院をつづけて いたが慢性的に Na 160 165 mEq/1程の高 Na血症を指摘されていた。外来精 查では尿崩症は否定的とされ、自覚症状にとほしく経過観察されていた。今 回、下肢の脱力感で前医を受診し、 $\mathrm{Na} 192 \mathrm{mEq} / \mathrm{l}$ 、血糖 $507 \mathrm{mg} / \mathrm{dl} 、 \mathrm{HbAlc}$ $8.1 \%$ 、尿ケトン陰性で当院を紹介され入院した。【院時所見】意識清明、体 温 $37.2^{\circ} \mathrm{C}$ 、血圧 $106 / 44 \mathrm{mmHg} 、 \mathrm{HbAlc} 8.3 \%$ 、Cre $1.09 \mathrm{mg} / \mathrm{dl}$ 、 $\mathrm{Na} 188 \mathrm{mEq} / \mathrm{l}$ 、 $\mathrm{K} 2.6 \mathrm{mEq} / \mathrm{l} 、 \mathrm{Cl} 150 \mathrm{mEq} / /$ 以上、血墏浸透圧 $416 \mathrm{mOsm} / \mathrm{kg}$ 、尿浸透圧 1179 $\mathrm{mOsm} / \mathrm{kg}$ 【入院後経過】高血糖は補液とインスリンで速やかに改善した。し かし $\mathrm{Na}$ 低下したが $\mathrm{Na}$ 150 155 mEq/1にも関わらず口渴感にそしく、これま での推移から背景に本態性高 $\mathrm{Na}$ 血症が疑われた。内分泌学的精查の結果、甲 状腺機能低下と成長ホルモン分泌不全と低ゴナドトロピン性性腺機能低下症 を認め、rT4製剂とhCG-hMG 療法+rFSH 療法を開始した。下垂体機能低下 症を併発した本態性高ナトリウム血症と評価し、飲水励行のみで $\mathrm{Na} 160 \mathrm{mEq} /$ はをこえず経過し退院した。【考察】本態性高 Na 血症は中枢性の Na・浸透圧調 整能の低下、口渴感の低下などの存在を認め慢性的な高 $\mathrm{Na}$ 血症をきたす稀な 疾患である。現在その原因は明らかでないが、中枢性、脳弓下器官が障害部位 と疑われ、高Nax抗体による障害が示唆されている。今回、本態性高 $\mathrm{Na}$ 血症 の一例を経験し、若干の文献的考察を加えて報告する。

\section{2-7-4 肝臓特異的Elov16欠損マウスの肝臟ではC18- ceramideが隇少することによりインスリン感受 性が亢進する}

松坂 賢、久芳 素子、小安さ扔り、本村 香織、大野 博、 Sharma Rahul、武内 謙憲、矢作 直也、宮本 崇史、関谷 元博 中川 嘉、島野 仁

筑波大学 医学医療系 内分泌代謝・糖尿病内科

【目的・方法】Elov16はC16からC18への飽和・一価不飽和脂肪酸の伸長を担 う脂肪酸伸長酵素である。本研究では䀒矌特異的Elov16欠損 (LKO) マウ スを用いて、肝臓のエネルギー代謝およびインスリン感受性の制御における Elovl6の役割を解析した。【結果】高ショ糖食 (HSD) を給餌すると、Floxに 比べてLKOマウスではインスリン感受性が充進した。肝臓のマイクロアレイ 解析により、HSDで発現が増加し、Floxに比べてLKOマウスで発現が低下 する遺伝子としてPnpla3を見出した。アデノウイルスによりPnpla3を肝臟で 発現させると、HSD給领下のLKOマウスのインスリン感受性の允進がキャン セルされた。肝臟の脂質メタボローム解析により、Elovl6およびPnpla3によ りその量が変化してインスリン感受性を制御する脂質として ceramide(d18:1 C18:0)を見出した。ヒト肝癌由来細胞株HepG2に扔いて、ceramide(d18:1/ C18:0)はインスリン刺激によるAktのリン酸化を減弱させた。この作用は ceramide(d18:1/C18-0)がPP2A の内因性阻害因子SET/I2PP2Aに結合するこ とによりその機能を阻害し、PP2A活性が上昇することによるものであった。 【結論】Elov16は肝臓のセラミドの側鎖長を制御することにより、インスリン 感受性を制御すると考えられる。

\section{2-7-6 腸管における GLP-1 分泌制御の解明}

三浦 雅臣、五十嵐 正樹、中川 佳子、山内 敏正、門脇 孝 東京大学医学部附属病院 糖尿病・代謝内科

【目的】腸管は、糖代謝や肥満を制御する最大の内分泌臟器として注目を集め ており、腸管上皮に発現するSIRT1は、長寿遺伝子として、腸管上皮の加齢 性変化に重要な役割を果たす遺伝子であると考えられている。腸管に発現する SIRT1に着目して、加齢との関連から、肥満や糖代謝に与える影響を調べるこ とを目的とした。方法】晹管上皮特異的SIRT1 ノックアウトマウスに高脂肪 食を負荷し、その糖代謝に与える影響を調べた。また、影響を与える因子につ いて、腸管内分泌細胞を用いてメカニズム解析を行った。成績】高脂肪食を 負荷したSIRT1 ノックアウトマウスは、野生型マウスと比較して、体重、イ ンスリン抵抗性の変化を認めた。また、SIRT1ノックアウトマウスでは、いく つかの腸管ホルモンの分泌量が変化していた。培盖細胞を用いたメカニズム解 析では、上記結果を説明・示唆しうる因子が同定された。【結論】腸管に発現 するSIRT1は、腸管ホルモンの制御を通じて糖代謝、肥満を制御しているこ とが示唆された。腸管のSIRT1を通じた腸管内分泌細胞の制御は、肥満・糖 代謝改善のターゲットとなりうる。 


\section{$02-7-7$}

成人先天性甲状腺機能低下症患者 106 名の臨床像 解析：甲状腺腫例では高頻度に甲状腺結節を認め る

杉澤 千穂 ${ }^{1}$ 、吉村 弘 $^{1} 、$ 星山 綾子 ${ }^{1}$ 、蛭間 真梨乃 ${ }^{1}$ 、川口 明子 ${ }^{1} 、$

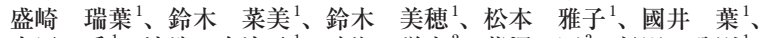
吉原 愛 ${ }^{1}$ 、渡邊 奈津子 ${ }^{1}$ 、鳴海 覚志 ${ }^{2}$ 、菱沼 昭 ${ }^{3}$ 、杉野 公則 ${ }^{1}$ 、 伊藤 公 $^{1}$

${ }^{1}$ 伊藤病院、 ${ }^{2}$ 国立成育医療研究センター研究所 分子内分泌研究部、 ${ }^{3}$ 獨協医 科大学 感染制御・臨床検查医学講座

【背景】先天性甲状腺機能低下症 $(\mathrm{CH})$ のマススクリーニング開始から 40 年が 経った。成人 $\mathrm{CH}$ 患者の臨床像の報告は少なく、特に甲状腺超音波画像を体系 的に評価した報告はない。

【目的】成人 $\mathrm{CH}$ 患者の臨床像を検討する。

【方法】1978年以降に出生し2001年1月から2019年3月に伊藤病院を受診した $\mathrm{CH}$ 患者109名のうち甲状腺超音波を受けた106名を対象とした20歲以上で の初回の受診時のデータを収集した。超音波計測値をもとに甲状腺腫、正形 成、形成異常に分類した。11 mm以上の径の結節を有意とした。

【結果】対象 106 名 (男性 32名、女性 74名)の評洒時年齢中央値は23(range 2036)歳、甲状腺形態は甲状腺腫 14 名、正形成26名、形成異常66名であった。 身長は男性 $170.3 \pm 6.2 \mathrm{~cm}$ 、女性 $157.2 \pm 5.4 \mathrm{~cm} 、$ BMI $21.5 \pm 3.4 \mathrm{~kg} / \mathrm{m}^{2}$ であっ た。LT4補充量中央値は 1.9 (range 0.0-5.6) $\mu \mathrm{g} / \mathrm{kg}$ であった。甲状腺結節を 13 名に認め $12 \%$; 文献的参照值 $6.6 \%) 、 う ち 12$ 名は甲状腺腫例であった。この うち 3 名が甲状腺切除術実施例、遺伝子解析を実施した7 名全例が遺伝子診断 確定例(TG変異4名、TPO変異 3 名)であった。

【考察】成人期 $\mathrm{CH}$ 患者のうち、甲状腺腫例に执いて甲状腺結節が極めて高頻 度に認められた。甲状腺腫性 $\mathrm{CH}$ では結節出現を念頭に超音波検查による経過 観察を行うべきと考える。

\section{2-7-9 学童期肥満における肥満進行の期間が病態に及ぼ す影響}

多久 葵、山本 幸代 ${ }^{1,2}$ 、島本 太郎 ${ }^{1} 、$ 池上 朋未 ${ }^{1}$ 桑村 真美 ${ }^{1}$ 、 齋藤 玲子 ${ }^{1}$ 、後藤 元秀 $^{1}$ 、久保 和泰 ${ }^{1}$ 、川越 倫子 ${ }^{1}$ 、河田 泰定 ${ }^{1} 、$ 楠原 浩一

${ }^{1}$ 産業医科大学 医学部 小児科、 ${ }^{2}$ 産業医科大学 医学部 医学教育担当教員

学童期肥満において、短期間で肥満が進行したのか、長期間継続しているの かという進行期間の差が病態に与える影響について検討した。対象は2016〜 2018年度に北九州市小・中学校の定期健康診断で高度肥満・肥満の急進を判定 され受診した児の中で、渦去 3 年の肥满度が判定できた児 137 名 (M-87) 3 年以 内の肥满度 $20 \%$ 以上悪化を短期群、それ以外を長期群とし、小児肥满症(OB) およびメタボリックシンドローム (Mets) の観点から検討した。年歯( (mean $\pm \mathrm{SD}): 11.2 \pm 1.9$ 歳、肥満度 $(\mathrm{mean} \pm \mathrm{SD}): 41.8 \pm 18.1 \%$ 、肥満重症度は高度:41名, 中等度:56名,軽度: 30 名。短期群：92名 (67\%)、長期群: 45 名 (33\%)。全対象者の OB:127名 (92\%)、Mets:50名(36\%)。肥満重症度別の比較、短期群と長期群の比 較では、 $\mathrm{OB} /$ Metsの診断基準項且有所見率は、高度肥満群と長期群で有所見 率が高い傾向であった。その中でTG $\geqq 120 \mathrm{mg} / \mathrm{dL} 、 \mathrm{ALT} \geq 25 \mathrm{IU} / \mathrm{L}$ は、中等 度以上では短期群と長期群で同等の有所見率であった。肥満が長期間持続する ことにより、健康障害のリスクが上昇するが、中性脂肪の上昇㧍よび異所性脂 肪蓄積は肥満進行の早期から進行する可能性があり早期診断・介入が必要であ る。

\section{2-8-2＼cjkstart肥満は特発性アルドステロン症における重要な背 景因子の一つである}

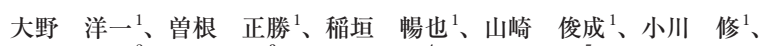
武田 仁勇 ${ }^{2} 、$ 栗原 勲 ${ }^{3} 、$ 馬越 洋宜、一城 貴政 ${ }^{5}$ 、方波見 卓行 ${ }^{6}$ 、 成瀬 光栄 4 JPAS研究班 ${ }^{4}$

${ }^{1}$ 京都大学、 ${ }^{2}$ 金沢大学、麖応義塾大学、 ${ }^{4}$ 京都医療センター、 ${ }^{5}$ 横浜市東部病 院、 ${ }^{6}$ 聖マリアンナ医科大学横浜市西部病院

【目的】アルドステロンと肥満や代謝障害との関連については以前から報告さ れている。原発性アルドステロン症野ルドステロン産生腺腫(APA)と特発 性アルドステロン症(IHA) という2つのサブタイプに大別されるが、両病型間 の肥满・代謝障害の相違についてこれまで十分検討されていなかった。そこ で全国29施設共同で構築したPA患者データベース (JPAS)を用いて、APA と IHA 間における代謝指標の比較を行った。【方法】サブクリニカルクッシング 症候群合併例を除外し、副堅静脈サンプリングで分類した516例の APA患者 と 1015例のIHA患者データを抽出し、診断時の患者背景、BMI、肥満、糖尿 病、脂質異常症有病率の比較を行った。また、多変量解析で患者背景を調整 した上で、APA とIHA間の代謝指標の比較を行った。さらに年齢、性別、血 圧をマッチした本態性高血圧(EHT)患者との比較も行った。【結果】 APA群は IHA 群と比較して有意にPACが高く、血清K值が低かったが、BMI、肥満の 有病率は逆にIHA群で有意に高かった。さらに年齢、性別、PACといった患 者背景を調整してもBMI、肥满の有病率はIHA 群で有意に高かった。糖㽷病、 脂質異常症の有病率は両群で有意差を認めなかったが、HbAlcはIHA群で有 意に高く、患者背景調整後も高 TG 血症、及び低HDL-C血症はIHA群で有意 に多く認められた。また、EHT患者との比較では、IHA患者で有意に肥満の 有病率が高かった。結語】 IHA患者はAPA患者と比較してPACが低值であ るにも関わらず肥满の有病率が高く、肥满はIHAにおける重要な背景因子の 一つであると考えられた。
02-7-8 出生季節と母体娃娠中体重増加、出生児体格予後

松本 真明、上原 絵理香、太田 知子、永田 知裕、寺下 新太郎、 山口 朋恵、吉井 啓介、内木 康博、堀川 玲子

国立成育医療研究センター内分泌代謝科

【背景】出生季節は生涯に渡り各種疾患りスクと関連する。出生季節と体格に 関しては国ごとに報告が異なり、本邦発のデータが必要と考えられる。 【目的】出生季節ごとの娃娠経過、出生時・6歳時体格の特徵を明らかにする ことである。

【方法】対象は2010年以降に当院で出生、母子コホート研究に同意した単胎 児。3-8月出生を春夏群、 $9-2$ 月出生を秋冬群とした。出生体重が $990 \%$ ile をHFD、ミ90\%ileかつ>10\%ileをAFD、ミ10\%ileをLFDとし、6歳時BMIが 85\%ile 以上を Obese/overweight とした。

【結果】春夏群は281名、秋冬群は254名、計535名であった。母体妊娠中 体重增加は春夏群 $10.3 \pm 0.2 \mathrm{~kg}$ 、秋冬群 $9.7 \pm 0.2 \mathrm{~kg}$ であった $(\mathrm{p}=0.039)$ 。その 他母体背景に有意差はなかった。 HFD・AFD・LFDの割合は春夏群でそれ ぞれ $13.2 \% \cdot 79.4 \% \cdot 7.5 \%$ 、秋冬群で $10.6 \% \cdot 80.7 \% \cdot 8.7 \%$ であった $(\mathrm{p}=0.61)$ 。 Obese/overweightの割合は春夏群 $4.3 \%$ 、秋冬群 $9.6 \%$ であった $(\mathrm{p}=0.035)$ 。出生 体格ごとの解析で、春夏群・秋冬群で obese/overweightに至る割合は、HFD 児で $2.7 \% \cdot 18.5 \%(\mathrm{p}=0.075) 、 A F D$ 児で $4.0 \% \cdot 8.8 \%(\mathrm{p}=0.048) 、 \mathrm{LFD}$ 児で $9.1 \%$. $0 \%(\mathrm{p}=0.23)$ であった。

【考察】これまで妊娠中の母体体重変化、出生時・小坚期体格を一連のもの として出生季節ごとに比較した報告はない。出生体格が同程度でも秋冬群で Obese/overweightに至りやすかった。既報の動物実験でも出生前後・若年期 の低温環境への暴露で肥满・撕取エネルギー・脂肪細胞が増加することが示さ れている。

【結語】春夏群は秋冬群と比較し、娃娠中体重増加が大きかったが出生時体格 は同程度であった。一方で同区分の出生時体格でも Obese/overweightに至り づらく、6歳時Obese/overweightの割合は少なかった。

\section{2-8-1＼cjkstart原発性アルドステロン症患者における自律神経 機能とその関連因子についての検討一Hyogo Adrenal Metabolic Registry-}

木俵 米一、角谷 学、森本 晶子、三好 晶雄、角谷 美樹、 小阪 佳恵、庄司 拓仁、小山 英則

兵庫医科大学 内科学 糖尿病内分泌・免疫内科

【背景】体内に㧍けるアルドステロンの上昇は交感神経活動の活性化に関与す る可能性がある。原発性アルドステロン症(PA)の患者では自律神経機能の低 下が想定されるが、少数例が報告されているに過ざない。さらに交絡因子と して睡眠時無呼吸や睡眠の澌、内臟脂肪量などが想定されるが、これらの影 響を併せて検討した報告はない。そこで、本研究においては、多数例のPA患 者における自律神経機能とその関連因子について、高血圧を有する非PA患者 と比較検討した。【万法】対象者はHyogo Adrenal Metabolic Registryに登録 されたPA患者 120 名と、HSCAA コホート研究に登録され年齢をマッチング させた非PA高血圧患者 120 名である。患者背景に加え、自律神経機能評価は アクティブトレーサーによる 24 時間心拍変動指標、睡眠時無呼吸はアプノモ ニター、睡眠の質はアクテイグラフを用いて評価した。【結果】PA患者では 非PA患者と比較して心拍変動指標であるCVRRが有意に低く(PA; $13.5 \pm 0.2$, 非 $P A ; 14.5 \pm 0.3, p=0.03$ )、患者背景を含めた重回帰分析においても有意な関連 を示した $(\beta=-0.140, \mathrm{P}=0.02)$ 。一方、AHIや睡眼の質の指標、内臓脂肪量は 両群間で有意な差を認めず、PA患者におけるサブ解析でも自律神経機能と睡 眠指標、内臓脂肪量は有意な関連を認めなかった。結論】多数例の検討でも PA患者では自律神経機能の低下を認め、本結果から、PA 自律神経機能低 下との強い関連が示された。さらに、本関連においては、睡眠や内臟脂肪の影 響は限定的であった。

\section{2-8-3＼cjkstart特発性アルドステロン症と肥満の関連における性 差および皮下脂肪組織の意義}

澤山 渚、烟野 悠、海老原 健、倉科 智行、岡田 健太、 海老原 千尋、岡 聖典、黒田 百恵、甲賀 裕希子、晸谷 浩史、 渡邊 秀平、國友 直樹、河原 悠一郎、佐々木 崇洋、星出 聡、 齋藤 新介、岡田 修和、高橋 学、永島秀一、石橋 俊 自治医科大学附属病院 内分泌代謝科

【背景】原発性アルドステロン症（PA）は二次性高血压症の原因として最も 高頻度であり、その大部分は片側性のアルドステロン産生腺腫 (APA) か両 側性副腎過形成による特発性アルドステロン症（IHA）に起因する。肥満は IHA の危険因子であり、特に内臓脂肪の重要性が近年報告された（JCEM 103: 4456, 2018、J Endocr Soc 2: 1236, 2018)。またIHA 女女性が男性よりも多いこ とが知られている。【目的】 IHA と肥満の関連における性差拉よび皮下脂肪， 内臓脂肪の意義について梌討する。【方法】2006年1月から2019年7月に当院 で副腎静脈サンプリングを実施したPA 117 例（IHA 73例、APA 44例）を対 象にBMIや臍レベルCTによる脂肪面積などを性別、肥満度別に比較検討し た。【結果】男女合わせた解析では、BMIはIHAがAPAに比して有意に大き かった( $<0.004)$ この差は女性のみで認められ、男性では認められなかった。 非肥满者（BMI<25）に注目すると、内臓脂肪面積（VFA）はIHAがAPA に比して有意に大きく $(84.73 \pm 35.73, \mathrm{p}=0.028)$ 、皮下脂肪面積（SFA）には両 群間に差を認めなかった $(139.80 \pm 53.04 v s 109.81 \pm 54.75, \mathrm{p}=0.066)$ 。一方、肥

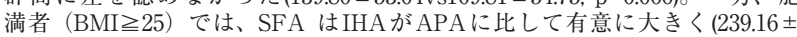

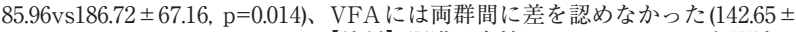
$64.50 \mathrm{vs} 137.89 \pm 49.13, \mathrm{p}=0.759$ )【結語】肥満は女性においての夕IHA と関連し た。非肥満者では内臓脂肪蓄積がIHA と関連したが、肥满者では予想に反し 皮下脂肪蓄積がIHA と関連した。 


\section{2-8-4 CYP11B2・変異KCNJ5を標的とした原発性アル ドステロン症の新規創薬}

星 啓太、横山 敦、五十嵐 萌、島田 洋樹

東北大学 大学院医学系研究科 分子内分泌学分野

原発性アルドステロン症（PA）は、副腎の過形成または腫瘍によりアルドス テロン（Ald）の過利分泌が生じる難治性高血圧症であり、本邦の高血圧患者 の約 $5 \sim 10 \%$ 占める。手術不能症例や両伹性病変には薬物瘵法としてスピ ロノラクトンやエプレレノンなどの Ald ブロッカーが用いられるが、副作用が 認められる・効果が不十分である等の理由から、PA 特異的な新规治療薬の開 発が求められている。一方、本邦の PA患者の約 $65 \%$ KCNJ5変異が認めら れることが知られている。 KCNJ5はK Kイオンを選択的に流入させることによ り膜電位を調整しているが、それに変異があるとKイオンの選択性が失われ て細胸内にNaイオンが流入し、その結果細胞膜が脱分極を起こして細胞内Ca 濃度が上昇しAldの過剩産生が起こる。我々は K 刺激による細胞膜の脱分極 を阻害することでAld合成酵素 (CYP11B2) の発現を抑制する薬凨を得る目 的で、東北大学ライブラリー（約6,200化合物）のハイスループットスクリー ニング（HTS）を行った。CRISPR-Cas9法を用いて内在性のCYP11B2遺伝 子座下流へルシフェラーゼ（Luc）遺伝子を挿入した紐胞（CYP11B2 N-Luc） を384well プレートに播種し、2 日後に薬剂を添加し、その 12 時間後に塩化力 リウム $(\mathrm{KCl})$ 刺激にて細胞を脱分極させ 6 時間後にLucアッセイを行った LucアッセイにてCYP11B2 発現抑制が見られた化合物について、細胞毒性や 濃度依存性の確認を行い 11 化合物まで絞り込んだ。さらに、それらをドキシ サイクリン誘導性に KCNJ5変異体（L168R）が発現する細胞に添加し、その CYP11B2 mRNAの発現阻害率を確認したところ、3化合物まで絞り込むこと が出来た。これらは、将来的なPAの新規治療薬たりうる可能性があることか ら、今後更なる解析を進めて行く

\section{$\underline{02-8-6}$}

\section{新規ミネラルコルチコイド受容体 (MR) ブロッ カー、エサキセレノンの高血圧実臨床での降圧効果 と安全性の検討〜他MRブロッカーからの切り換え 投与群 205 症例と追加投与群 34症例での検討〜}

佐藤 文俊、森本 玲 ${ }^{2}$ 、手塚 雄太 ${ }^{1,2} 、$ 尾股 慧 $^{2} 、$ 小野 美澄 ${ }^{2} 、$ 伊藤 貞嘉

東北大学大学院 医学系研究科 難治性高血圧内分泌代謝疾患地域連携寄附講 座、 ${ }^{2}$ 東北大学病院 腎高血圧内分泌科、 ${ }^{3}$ 公立刈田病院

【目的】新規ミネラルコルチコイド受容体(MR)ブロッカー、エサキセレノンの 高血圧患者治療の実臨床に扔ける降圧効果と安全性の検討を目的とした。【方 法】高血圧治療中の患者に扔いて、降圧不十分と診断した患者でMRブロッ カー未使用症例にはエキサセレノンの追加投与。他MRブロッカーを投与中の 患者に関しては患者に十分な説明の後エサキセレノンへの切り替え投与。 12 週前後の血圧、電解質、堅機能等を比較検討した。成績】 12 週継続使用し たエサキセレノン追加投与群は 34 症例あり、投与前収縮期血圧 (SBP) は 143.3 加投与後 $130.7 \mathrm{mmHg}$ に有意に低下 $(\mathrm{p}<0.0001)$ 、投与前搪張期血圧(DBP) は 83.8 から投与後 $77.6 \mathrm{mmHg}$ に有意に低下した $(\mathrm{p}=0.00156)$ 。エサキセレノン を継続使用した他 MR ブロッカーからの切り替え投与群は 205 症例あり、SBP は125.4から投与後 $118.2 \mathrm{mmHg}$ に有意に低下 $(\mathrm{p}<0.0001) 、 \mathrm{DBP}$ は 74.1 から 73.2 $\mathrm{mmHg}$ に低下傾向あったが有意差なし。平均投与日量は追加投与群は $1.43 \mathrm{mg}$ であり、切り替え群は $1.59 \mathrm{mg}$ であり、投与総数は $1.25 、 2.5 、 5 \mathrm{mg}$ の順。血 清カリウム漂度は、追加投与群では 4.11 から $4.38 \mathrm{mmol} / \mathrm{L}$ に有意に $(\mathrm{p}=0.0038)$ 上昇し、切り替え群では変化なし。投与前後で、eGFRは、追加投与群では、 76.4 から 71.7 と有意差 $(\mathrm{p}=0.0012)$ があり、切り替え群では有意差なし。【結論】 エサキセレノンは半減期が長いMRブロッカーであり低用量でも 1 日 1 回投与. でエプレレノンやスピロノラクトン以上の降圧力を示し、同等の安全性を示し た。

\section{2-8-8 MAX遺伝子に生死細胞変異を認めた両側褐色細胞 腫の一例}

畑 真之介 ${ }^{1}$ 、浅野 麻衣 ${ }^{1}$ 、橋本 善隆 1 間嶋 紗織 1 、千丸 貴史 ${ }^{1}$ 、 牛込 恵美 ${ }^{1} 、$ 中西 尚子 ${ }^{1}$ 、濱口 真英 ${ }^{1}$ 、山崎 真裕 ${ }^{1}$ 、本郷 文弥 ${ }^{3}$ 、 兒井 健 ${ }^{2}$ 、福井 道明

${ }^{1}$ 京都府立医科大学大学院医学研究科 内分泌 - 代謝内科学、2 京都府立医科 大学大学院医学研究科 泌尿器科学、 ${ }^{3}$ 静岡県立総合病院りサーチサポートセ ンター 臨床研究部遺伝研究部

【症例】44歳男性【経過】既往歴・家族歴なし。血圧: $116 / 76 \mathrm{mmHg}$ 、脈拍 $72 /$ 分。X-4年に健診の胸部CTで左副腎に $\phi 16 \mathrm{~mm}$ と $\phi 13 \mathrm{~mm}$ の腫瘤あり。血 中アドレナリン $0.03 \mathrm{ng} / \mathrm{mL}$ 、ノルアドレナリン $0.79 \mathrm{ng} / \mathrm{mL}$ 、随時尿中メタネ フリン $(\mathrm{MN}) 0.24 \mathrm{mg} / \mathrm{g} \cdot \mathrm{cre} 、 ノ ル メ タ ネ フ リ ン ~(\mathrm{NMN}) 0.62 \mathrm{mg} / \mathrm{g} \cdot \mathrm{cre}$ 。いず れもMRIでT1WI等信号、T2WI高信号で131I MIBGシンチで左副腎に集積 あり。褐色紐胞睡の診断で腹㬶鏡下左副堅摘除術が施行された。術後に随時 尿中NMNは正常化したが、X-1年に右副腎に $\phi 17 \mathrm{~mm}$ の腫瘤を指摘。尿中 $\mathrm{MN} \cdot \mathrm{NMN}$ は基準值内であった。 $\mathrm{X}$ 年に右副腎腫瘤は $\phi 25 \mathrm{~mm}$ と増大し、131I MIBG シンチで同部位に集積を認め蓄尿 MNO. $44 \mathrm{mg} /$ / 日、NMN0.48mg/日と高 值であり褐色細胞腫と診断。遺伝子検查でMAX遺伝子に病的変異を認めた。 【結論】近年、褐色細胞腫は従来考えられていたよりも遺伝性の割合が多いこ とが判明している。本症例の上うに多登性や両側性の褐色細胞腄では、一見孤 立例であってもMAX遺伝子を含めた家族性の可能性を念頭におくことが重要 である。同遺伝子変異の中でも本症例と同様のバリアントの報告はわずかであ る。本症例の治療方針や血縁者への検査、経過観察の間隔の決定には十分な検 討が必要と考える。

\section{2-8-5＼cjkstart原発性アルドステロン症におけるエプレレノンか らエサキセレノンへの切り替え症例の検討}

杉山 徹、山下 大翔、佐伯 浩介、早川 惠理 武蔵野赤十字病院 内分泌代謝科

【背景・目的】原発性アルドステロン症 $(\mathrm{PA})$ の薬物療法ではミネラルコルチコ イド受容体拮抗薬 (MRA)が第一選択となるが、本邦で認可されているエプレ レノン (EPL)の最大用量投与下においても血厈コントロールやレニン抑制解除 が不十分な PA 症例は多くみられる。本研究ではEPL最大用量投与下でもレニ ン抑制が解除されていないPA患者において新規MRAであるエサキセレノン $(\mathrm{ESX})$ への切り替えの効果について検討した。

【対象・方法】当院にて診断され、EPL100 mg/日投与下でも血漿レニン活性 (PRA) $1.0 \mathrm{ng} / \mathrm{mL} / \mathrm{hr}$ 未満を示したPA患者において ESXに切り替えた 18 例 （年齢 $55 \pm 10$ 歳、男性 8 例、女性 10 例）を対象とし、血压、PRA、血漿アルド ステロン濃度(PAC)、血液生化学所見、併用降圧薬の推移を検討した

【結果】 EPL $\rightarrow \mathrm{ESX}$ への切り替え 3 ケ月後までの経過では、併用薬使用 9 例中 6 例が併用薬を中止または減量できたうえに、全体で収縮期血圧 $(140 \pm 16 \rightarrow 130$ $\pm 9 \mathrm{mmHg}, \mathrm{p}<0.05)$ が有意に低下した。拡張期血圧 $(84 \pm 8 \rightarrow 84 \pm 6 \mathrm{mmHg}$, $\mathrm{p}=0.57)$ 、血清 $\mathrm{K}$ 值 $(4.3 \pm 0.3 \rightarrow 4.1 \pm 0.2 \mathrm{mEq} / \mathrm{L}, \mathrm{p}=0.07) 、 \mathrm{PRA}(0.5 \pm 0.5 \rightarrow 0.5 \pm$ $0.4 \mathrm{ng} / \mathrm{mL} / \mathrm{hr}, \mathrm{p}=0.39), \operatorname{PAC}(180 \pm 98 \rightarrow 186 \pm 78 \mathrm{pg} / \mathrm{mL}, \mathrm{p}=0.73)$ には有意な変 化がなかった。高 $\mathrm{K}$ 血症・肝腎機能の増悪など有害事象の出現はなかった。 【考察】ESXは第三世代の非ステロイド性MRAであり、MRに対する選択性・ 親和性ともに高く、半減期も長いとされる薬剤である。実臨床におけるPAの 治療薬として、ESXはEPLよりも強い降圧効果が示された。抑制されたレニ ンに関しては 3 ヶ月の時点では変化がなかったが、より長期的な効果を検討す る必要がある。

\section{2-8-7脊椎腫瘍の鑑別に苦慮した神経線維腫症 1 型に褐 色細胞腫を合併した 1 例}

飯岡 雅仁 ${ }^{1}$ 、早川 友朗 ${ }^{1}$ 、宮下 和幸 ${ }^{1}$ 、西澤 均 $^{1}$ 、小澤 純二 $^{1,2}$ 、

前田 法一 ${ }^{1,3}$ 、大月 道夫 ${ }^{1} 、$ 松岡 孝昭 ${ }^{1}$ 、福原 慎一郎 ${ }^{4}$ 、

${ }^{1}$ 大阪大学大学院 医学系研究科 内分泌 - 代謝内科学、 ${ }^{2}$ 大阪大学大学院 医学 系研究科 糖尿病病態医療学寄附講座、 ${ }^{3}$ 大阪大学大学院 医学系研究科 代謝 血管学寄附講座、 ${ }^{4}$ 大阪大学大学院 医学系研究科 泌尿器科

【症例】46歳男性。X-42年に神経線維腫症1型（以下、NF1）と診断を受け た。X-1年に第 11 胸椎圧迫骨折を発症し保存的加療となった。 X年 2 月中旬、 腰痛と右側腹部違和感を主訴に受診し腹部 CTにて右副腎腫瘍を認めた。24時 間酸性蓄尿にて尿中 NMNが正常上限の 3 倍以上の高值を認め、123I- MIBG シンチにて右副腎腫瘍に集積像を認めたことから褐色細胞腫と診断した。同 シンチや脊椎 MRIにて第 11 胸椎に脊椎腫瘍を認めた。春椎腫瘍の鑑別として 1 NF1に合併する神経鞘腫瘍、2 褐色細胞腫の骨転移、3 その他の腫瘍を考え た。沓椎MRIにて第11胸椎レベルで硬膜囊の拡張を認め、PET-CTにて副㹂 腫瘍と脊椎腫瘍ではSUVが異なり画像的に脊椎腫瘍はNF1に合併する神経鞘 腫瘍と考えた。右副腎腫瘍の摘出後に脊椎腫瘍の生検を行う方針とした。右副 腎腫瘍摘出術は術中合併症なく終了したが術後イレウスを発症し保存的加療後 に脊椎腫瘍のCTガイド下針生検を行った。脊椎腫瘍の病理組織診断は褐色細 胞腫の骨転移であった。考察】NF1は連伝性褐色細胞睡の原因遗伝子として も知られており 0.1-5.7\%に褐色細胞腫を合併する報告もある。本症例も NF1 と褐色細胞腫を合併したが123I- MIBG シンチで使用する核種はノルアドレナ リン様物質であり褐色細胞腫と NF1由来の神経腫瘍の鑑別は困難である。ま たPET-CTのSUVの差も本症例のように必ずしも腫瘍の鑑別に有用ではない ため、組織診断を行うまでは褐色細胞腫の可能性も含めた対応が必要と考えら れた。

\section{2-8-9 異所性副腎に褐色細胞腫が発症したMEN2Aの1 例}

大杉 治之、滝澤 奈恵、木下 秀文、松田 公志 関西医科大学 腎泌尿器外科

【緒言】副㹂は腎臟の上に位置するが、それ以外にも副腎組織が存在すること があり、異所性副腎と総称されている。異所性副腎のほとんどは無症状で偶発 的に見つかることが多いが、稀に異所性副腎に副腎腫瘍が発生することがあ る。

【症例】MEN2Aの家族歴のある 21 歳女性。頭痛と動悸あり、MRIにて両側副 婜に囊胞性腫瘍を認めた。 ${ }^{123}$ I-MIBGにて両側副婜に焦皘あり、尿中メ夕ネフ リン分画高值であり、両側褐色細胞腫の診断であった。一期的に両側の腹胿鏡 下副腎摘除術を施行。術後5 ケ月の尿中メタネフリン分画は基準值以下になら ず、術後 12 ケ月で上昇傾向であった。MRIにて腎門部大動静脈間に $30 \mathrm{~mm}$ の新たな腫瘍性病変が確認され、 ${ }^{123} \mathrm{I}-\mathrm{MIBG}$ にて同部位に集積を認めたため、 開腹腫瘍摘除を施行。組織学的な評価では、腫瘍部位は、類円形核を有する 細胞が胞巣構造や索状構造をとって増殖しており、また免疫組織化学的には chromograninがびまん性に陽性であった。興味深い事に、腫瘍の外縁の一部 で泡沫状の淡明細胞の層構造の形成を認め、その外縁には被膜構造が存在して いた。これは、副腎皮質の存在を示唆する所見であり、診断は、異所性副腎に 生じた褐色細胞腫であった。術後尿中メタネフリン分画は基準値以下となり、 ${ }^{123} I-M I B G て ゙ も$ 明らかな集積は認めなかった。現在、術後 5 年経過するが褐色 細胞腫や傍神経節腫の再発は認めていない。

【考察】副腎は、発生学的には、中胚葉由来の体哚上皮から副腎原基が形成さ れ、外胚葉由来の神経堤細胞が副腎原基に貫入し副腎髄質が形成される。異所 性副腎は、発生学的異常であり、副腎の発生過程を紐解き、好発部位や臨床的 問題点について検討する。異所性副腎に副腎皮質腫瘍が発生した報告は散見さ れたが、褐色細胞腫が発生した報告は本症例が世界初と考える。 


\section{2-9-1}

バセドウ病に対する放射性ヨウ素内用療法におい てヨウ素摂取量および無機ヨウ素治療が治療効果 に与える影響に関する検討

西尾 理恵 ${ }^{1} 、$ 内田 豊義 ${ }^{1} 、$ 鈴木 路可 ${ }^{1}$ 、後藤 広昌 ${ }^{1} 、$ 小野瀬 裕之 ${ }^{2}$ 、增山 敦 1 、小宮 幸次 ${ }^{1}$ 、山田惠美方 ${ }^{2}$ 、綿田 裕孝 ${ }^{1}$ 順天堂大学大学院 医学研究科 代謝内分泌内科学、 ${ }^{2}$ 金地病院

【背景】放射性ヨウ素内用療法(RAIT)の治療効果に術前無機ヨウ素治療やヨ ウ素摂取状況が与える影響は十分に検討されていない。【目的】 RAITの治療 効果およびその治療効果にRAIT 前のヨウ素治療およびヨウ素摂取量が与える 影響を検討した。【方法】バセドウ病患者81名を対象に全例7日前からヨウ素 制限、5 日前加抗甲状腺薬 (ATD) もしくは無機ヨウ素( KI)を中止、甲状腺機 能 $(\mathrm{TH}) 、$ 甲状腺推定重量 (eTV)、早朝尿中ヨウ素排泄量 (UIE) を測定し、fixed dose approach (131I,13.0mCi,1回投与) にて治療を行い、72時間後の放射性ヨ ウ素摂取率を測定した。その後、主治医の裁量で治療を行い、1年後の TH、 eTV、治療方法を検討した。治療効果は 1 年後の治療方法にて評価し、抗甲状 腺薬のいかなる使用も機能立進群、それ以外を機能低下群とした。RAIT1年 後の治療効果を分類し、その治療効果に関わる治療効果規定因子をとUIEか ら算出したヨウ素摂取量やRAIT 前治療の差異を取り込んだロジスティック回 䚻分析にて検討した。補完的にATD と KIの各単独治療患者の術前における臨 床的背景をマッチングさせ、前治療による治療予後の差異を 2 群間検定で検討 した。【結果】RAIT1年後の機能低下群は $56.8 \%$ であり、治療効果規定因子は 治療前のeTVであった。RAT前のヨウ素治療、KI投与量およびヨウ素摂取 量が治療効果に与える影響は認められなかった。また術前 ATD 治療群と KI治 療群に治療効果の差異は認めなかった。【結語】本治療法の休薬期間において 術前治療がKIであること、適切なヨウ素制限下のヨウ素摂取量が治療効果へ の及ほす影響は少ないと考られた。

\section{2-9-3 バセドウ病授乳婦に対する MMIとKI併用療法が児 の甲状腺機能に与える影響}

濱田 勝彦 ${ }^{1}$ 丸田 哲史 ${ }^{1}$ 、溝上哲也 ${ }^{1}$ 東 輝一朗 ${ }^{1}$ 、百溪 尚子 2 、 田尻 淳一

${ }^{1}$ 田尻クリニック、 ${ }^{2}$ 四谷甲状腺クリニック

【背景】バセドウ病授乳婦への少量から中等量のチアマゾール(MMI) 単独投与 は乳児甲状腺機能に悪影響を与えないことが報告されている。我々は 2017 年 の甲状腺学会で、バセドウ病授乳婦に対するヨウ化カリウム(KI) 単独療法は 多くの児の甲状腺機能に影響を与えなかったことを報告した。【目的】バセド ウ病授乳婦に対するMMI と KI併用療法が児の甲状腺機能に与える影響を調 べる。対象と方法】対象は2009年1月から 2019年6月の間に MMI と KI併用 療法で治療されたバセドウ病授乳婦の児 28 児。MMI と KIを併用した理由は 各々単独療法では効果不十分なため、副作用回避目的でMMIの投与量を抑元 るため、である。咱の採血は簡便で侵襲の少ない滤紙採血で行った。先天性甲 状腺機能低下症マス・スクリーニングガイドラインを参考に、生後6 ケ月未渵 で血中 TSH $\geq 10 \mathrm{mIU} / \mathrm{L} 、$ 生後 6 个月以隆で血中TSH $\geq 5 \mathrm{mIU} / \mathrm{L}$ を潜在性甲状 腺機能低下症と診断した。【結果】28児から述べ57検体得られた(月齢:中央値 5 ヶ月 $[0 \sim 12]$ 、 KI 投与量: 中央值 $50 \mathrm{mg}$ [ $14.3 \sim 50]$. MMI 投与量: 中央値 $15 \mathrm{mg}$ [5 20])。28児中 27 児(54検体)の甲状腺機能は正常であった。1 児( 3 検体)に 軽度の潜在性甲状腺機能低下症（TSH: $5.6 \sim 8.2 \mu \mathrm{IU} / \mathrm{mL}$ ）を認めた。【結論】 バセドウ病授乳婦に対する MMI と KI( $50 \mathrm{mg} /$ 日)併用療法は、ほとんどの児 の甲状腺機能に影響を与えなかった。

\section{2-9-5 抗甲状腺薬によるバセドウ病の治療開始時期と経 過の季節変動に関する検討}

片平 正人 ${ }^{1,2}$ 、尾方 秀忠 ${ }^{2} 、$ 溝口 暁 2 、山口 麻里子 ${ }^{2}$ 高島 裕美 2 千葉 彩加

愛知県立大学 看護学部、2 - 宮市立市民病院 糖尿病・内分泌内科

【目的】バセドウ病の発症には季節変動があり、暖かい時期に発症しやすいと 報告されている。また、抗甲状腺薬（ATD）休薬後の再発については春から 夏にかけて多いとする報告がある。しかし、甲状腺機能の季節変動の観点か ら、ATD開始から休薬・再発までを総合的に検討した報告はない。そこで今 回我々は、バセドウ病に対する ATD開始時期と、その後の治療経過中の甲状 腺機能の季節変動を調査した。

【方法】2015年1月から2018年12月までに当科外来にバセドウ病で受診した 414名の患者を後乃向きに調査した。また、治療経過については、ATD開始 後6か月以内のデー夕と、放射線・手術療法に変更した場合の以後のデー夕は 検討から除外した。

【成績】ATD 開始時期は、夏（6８月）が136名（32.9\%）で有意に頻度が高 く、冬 (12〜2月) が78名 $(18.8 \%)$ で有意に頻度が低かった。一方、FT3は 春（3～5月）と冬が秋（9１1月）よりも有意に高く、FT4は春が秋よりも 有意に高かった。TSHに有意差は見られなかった。治療経過では、FT3は春 と冬が夏と秋上りも有意に高かった。T44は春と冬が秋上りも有意に高かっ た。一方、FT4, TSHが正常化するまでの期間、TSH、TRAbに有意差はみ られなかった。また、ATD休薬後の治療再開は98名で認められ延心゙139回で あったが、春に再開となる場合が46回 $(33.1 \%)$ と有意に高かった

【結論】バセドウ病は夏に発症することが多く、春や冬に発症する場合は甲状 腺機能が高くならないと発症せず、秋に発症する場合は甲状腺機能が低めです 発症する可能性が示唆された。また、治療経過においては、冬から春にかけて 疾患の活動性が允進し、春に再発しやすい可能性が示唆された。

\section{2-9-2 バセドウ病に対する放射性ヨウ素内用療法後に TSAbが低下から上昇に転じる症例の検討}

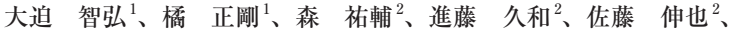
高橋 広告、山下 弘幸 ${ }^{2}$

${ }^{1}$ やました甲状腺病院 内科、 ${ }^{2}$ やました甲状腺病院 外科

【背景】我々は過去の学会でバセドウ病の放射性ヨウ素内用療法（RAIT）で 単位休皘あなりの131-Iの投与量を多く設定した方が、治療後のTRAbあるい はTSAbの上昇が見られにくい、または、一旦上昇を認めても早期に低下に転 じる可能性について報告してきた。しかし、症例を集積する中で、RAIT後、 一旦TRAb、TSAbの低下傾向を認めるも上昇に転じる症例を少なからず経験 した。【目的】今回我々は、RAIT後、一旦TSAbの低下傾向を認めた症例に おいて、そのままTSAbの低下傾向が維持される症例と上昇に転じる症例の臨 床的特徵を評価することを目的とした。【対象】2011年6月から 2019 年5月ま でに当院でRAITを施行しTSAbをフォローできた47例のうち、RAIT後 3 ケ 月の時点でTSAbが治療前と比較し低下傾向を認めた 24 例。性別は全て女性。 【方法】対象のうち、RAIT後 6 ケ月の時点でTSAbがさらに低下傾向を認めた 群を D群、上昇に転じた群を E 群とし、単位体積当たりの131-I投与量、131-I 投与量、治療前甲状腺重量、RAIU、RAIT後 3 个月と 6 ケ月後の甲状腺重量縮 小率、喫煙、術後再発の有無について比較検討した。【結果】D群において単 位体積あたりの131-I投与量、6 个月後の甲状腺重量縮小率が有意に高い傾向 を認めた（いずれも $\mathrm{p}<0.05 ）$ 。考察】十分量の131-IでRAITを行い、甲状腺 腫の有意な縮小を得ることができればRAIT 後のTSAb上昇を回避できる可能 性があると考えられる。

\section{2-9-4 未治療バセドウ病の病勢は加齢、性の影響を受け るか?}

鈴木 菜美、杉澤 千穂、星山 綾子、鈴木 美穂、松本 雅子、 國井 葉、吉原 愛、渡邊 奈津子、吉村 弘、杉野 公則、 伊藤 公一 伊藤病院

バセドウ病 (GD) は若年女性に多く発症するが、治療経過に関しては性や年齢 差が報告されている。GDの発症時の各因子について性および年齢差の有無を 検討した。【方法】2005年1月〜2019年6月に診断された未治療GD21775例、 女性 17803 例、男性 3972 例を、䛦療録をもとに後方視的に検討。【結果】各 年龄群は4-9歲38例 $(\mathrm{F} \cdot \mathrm{M})=31: 7 、 10-19$ 歲1199例 $(\mathrm{F} \cdot \mathrm{M})=1032: 167$, 20-29歳 4138例 $(\mathrm{F}: \mathrm{M})=3464: 674 、 30-39$ 歳 6246例 $(\mathrm{F}: \mathrm{M})=5062: 1184$ 、 40-49歳 4843例 (F:M) $=3887: 956 、 50-59$ 歳 3133 例 (F:M) $=2570: 563$ 、 60-69歳 1590例（F:M） $=1270: 320 、 70-79$ 歳 518例（F:M） $=425: 93$ 、 80-92歳 70例 $(\mathrm{F}: \mathrm{M})=62: 8$ であった。各因子の年齢毎の中央值は FT4 4 ng d) 4-9歲 5.50, 10-19歲 5.85, 20-29歲 522, 30-39歲 478, 40-49歲 4.47, 50-59歲 3.97, 60-69歳3.56, 70-79歳 3.17, 80-89 歳 3.1、TRAb(IU/L) は4-9歳 21.6, 10-19 歳 17.0, 20-29歳 13.2, 30-39歳 12, 40-49歳 11.7, 50-59歳 9.6, 60-69歳 8.4 70-79歳 7.75, 80-89歳 5.5であり、いずれの因子においても Wilcoxon検定で有 意差を認め、FT4,TRAbは加齢と共に減少した。甲状腺容量も10才以降は加 龄とともに減少した。男女別の同样の梌討でも有意差を認めた。各年龄群で FT4,TRAb, 甲状腺容量を性別比較検討すると、FT4は20-39歳で男性に有意 に高く、甲状腺容量は10-79歳で男性に有意に多かった。【考察】 FT4,TRAb 甲状腺容量は加龄に伴い減少し、性別では青年期の男性でFT4が有意に高 かった。若年発症者は遺伝的素因による影響、高齢発症者では甲状腺細胞の TRAb刺激に対する反応性の低下による影響等が考只られ、性差に関しては免 疫系へのエストロゲンによる影響等が考えられた。

\section{2-9-6 甲状腺機能正常者における血中TSH値とFT4值の 季節変動}

山田 早耶香 1 、中島 康代、錦戸 彩加 ${ }^{1} 、$ 阿久沢 まさ子 ${ }^{2} 、$

坂巻 浩二 ${ }^{2}$ 、土岐 明子 ${ }^{1}$ 、石田 恵美 ${ }^{1}$ 、下村 洋之助 ${ }^{2}$ 、小林 功 $^{2}$ 、 安藤 義孝 ${ }^{2}$ 、山田 正信 ${ }^{1}$

群馬大学 内分泌代謝内科学、 ${ }^{2}$ 高崎日高病院

【目的】甲状腺ホルモンは全身の代謝維持に重要で脂質代謝異常や心機能、骨 代謝等へ影響を及ほすすしたがって正確な甲状腺機能評価が重要だが、甲状腺 機能は、年龄や性差、ヨード摄取や哪煙などの諸因子により変化する。本研究 では人間ドックのデータから甲状腺機能の季節変動について性別、年代別に検 討した。【対象と方法】対象は2006 2013年の日高病院人間ドック受診者で、 血中 TSH值・FT4 值が基準值内である14,203例とした。甲状腺機能の月別変 化について、男女別に年齢・喫煙の影響も考慮し検討した。【結果】男性 8.489 例、女性 5,534 例で平均年龄は男性 $49 \pm 10$ 歲女性 $48 \pm 10$ 歲。目別受診者は 最低 173 例、最高 961 例。男性での月別 TSH 中央値は 1 月で最高值 $1.6 \mu \mathrm{U} / \mathrm{ml}$ 、 $6,7,8,9$ 月で最低值 1.3 であり、年間中央值は 1.4 だった。女性では 5,12 月で最 高值 $1.7 、 7,8$ 月で最低值 1.5 、年間中央值 1.6 だった。ランク変換分析では男性 で1, 12 月に有意に高值、7，9月で有意に低值と冬期に高値、夏期に低值を示 した。一方、女性では年間を通して有意な差は認めなかった。FT4値におけ るランク変換分析では、男女ともに11,12月に有意に高值、8月に有意に低值 となった。年代別では高歯者や若年女性で血中 TSH 值の季節変動幅の縮小を 認めた。また男性鄙煙者 2,262 例、非喫煙者 4,709 例の検討では、喫煙者では TSH 值が低值（中央值：喫煙者 1.2、非喫煙者1.5）であり、TSH値と FT4值 ともに非契煙者と比較し季節変動幅が縮小した。結論】血中TSH値、FT4值 は冬期に高值、夏期に低值となるが、高龄者や女性、喫煙者では季節変動幅は 縮小する。甲状腺機能の正確な評価のためには、測定時期も考慮する必要があ る。 


\section{2-9-7 バセドウ病 (GD) 患者への抗甲状腺薬 (ATD)} 治療におけるMPO-ANCA測定について

鈴木 美穂、吉村 弘、渡邊 奈津子、吉原 愛、國井 葉、 松本 雅子、鈴木 菜美、蛭間 真梨乃、川口 明子、盛崎 瑞葉、 杉澤 千穂、星山 綾子、杉野 公則、伊藤 公一

伊藤病院

【背景】ANCA関連血管炎(AAV)はGDに対するATD治療中に生じうる。重 症例を主とする本邦の報告ではGD1万人あたり $0.5 \sim 0.8$ 人と稀だが重篤化の 可能性がある有害事象で適切な管理を要す。通常MPO-ANCA 陽性となるが $\mathrm{AAV}$ 未発症の GDでも陽性を示すこともあり、ANCA測定や陽性判明時の ATD中止の要否について指針はない。【目的】ATD治療中のGD患者におけ るMPO-ANCA測定の実際を示し有用性を検討する。【対象と方法】2005 17 年に当院初診の未治療 GD患者でATDを開始した 18558 例を対象に後方視 的に解析した。【結果】 MMI投与-14271例中 266 例、PTU投与4 287 例中 385例 でANCAが測定された。陽性例は74例でMMI1例 $(0.4 \%) 、$ PTU73例 $19 \%$ ) とPTUに高率だった。測定理由は長期服薬中に無症状で測定(240例)された 他、AAVを疑う症状出現時に澌定された(411例)。無症状例での ANCA 陽性 は36例 $(15 \%) 、 A A V$ 疑い症状例で 38 例 $(9.2 \%)$ だった。ATD開始からANCA 測定までの期間と ANCA 陽性率をみると 1 年以内で $2.5 \%$ と少なく、その後は 継続してANCA 陽性率は $20 \%$ 前後だった。陽性判明 74 例中 70 例 $(95 \%)$ で 131 内用療法 $(26$ 例 $) 、$ 手術 $(7$ 例 $) 、$ 内服薬変更 $(29$ 例)、内服中止 $(8$ 例 $)$ 一と変更され AAV湿性化や重症化を認めなかった。無症状でANCA弱陽性が判明した 4 症 例で中央値 2 年[範囲 1.1 26] 間、PTUが注意深く継続され同期間中に AAV は発症しなかった。【結語】初発GDでATD治療を開始した18558例において $\mathrm{AAV}$ の顕性化や重症化を認めなかった。【考察】 MPO-ANCAの適時測定と 陽性判明時の治療変更が奏功した可能性が考えられるが、陽性判明後PTU継 続にても AAV未発症であった例も少数存在し引き続き検討を要している。

\section{2-9-9 抗甲状腺薬に関連する有害事象報告の特徵： JADERデータベースを用いた解析}

新井 正法、白川 純、寺内 康夫

横浜市立大学大学院 医学研究科 分子内分泌・糖尿病内科学

【背景】抗甲状腺薬のチアマゾール (MMI) とプロピルチオウラシル (PTU) は 有害事象 (AE) が知られている。【目的・方法】2018年7月時点の医薬品副 作用データベース（JADER）を用いMMI とPTUのAEに関するReporting odds ratio (ROR)を算出し、その特徴を明らかにする。【結果】全AE報告 519423 例中、MMI : 2749例、PTU : 898例であった。3例以上かつROR>1 であったAEは127種あり、RORがZ検定でMMIに多かった AEは、無顆 粒球症(MMI:90.09, PTU:20.94（以下同様）： $<<0.0001$ 、先天性皮膚形成不全 (7435.52, 46.97; $\mathrm{p}=0.00017$ )、臍带ヘルニア $(2964.64,156.67 ; \mathrm{p}=0.0005)$ 、卵黄腸 管遺残 $(1607.51,68.08 ; \mathrm{p}=0.0028)$ 、腸管瘦 $(441.92,89.23 ; \mathrm{p}=0.017)$ を含む 8 種で あった。PTUで多かったAEは、抗好中球細胞質抗体陽性血管炎(MMI:46.78, PTU:1750.82（以下同様）： $<<0.0001$ )、急速進行性系球体腎炎 $22.67,122.72$; $\mathrm{p}<0.0001)$ 、肺胞出血 $(1.42,13.56 ; \mathrm{p}<0.0001)$ 、抗好中球細胞質抗体陽性 $(28.22$. 638.43; $\mathrm{p}=0.0003$ )、関節痛 $(3.82$, 11.38; $\mathrm{p}=0.0004)$ を含む19種あった【結論】 MMI で無顆粒球症、皮䖉や腸管の奇形などが多く、PTUでANCA関連血管炎 などが多く報告されていた。娃娠初期のPTU使用等の背景や内在するバイア スによる結果の解釈を含めて報告する。

\section{2-9-11 化合物スクリーニングを用いた甲状腺ホルモン脱 ヨード酵素の新規調節因子の探索}

山内 一郎 ${ }^{1}$ 、坂根 依利子 ${ }^{1,2}$ 、伯田 琢郎 ${ }^{1} 、$ 小 貴史 $^{1}$ 、 植田 洋平 ${ }^{1}$ 、藤井 寿人 1 、八十田 明宏 ${ }^{1}$ 、稻垣 申 $^{\text {是也 }}{ }^{1}$

${ }^{1}$ 京都大学大学院 医学研究科 糖尿病・内分泌・栄養内科学、2京都大学医学 部附属病院 先制医療・生活習慣病研究センター、 ${ }^{3}$ 国立病院機構 京都医療七 ンター 臨床研究センター

【背景】甲状腺ホルモン脱ヨード酵素（D1、D2、D3）の調節因子は未だ不明 な占が多く、検出には醉素活性の測定が一般的に用いられるが、ラジオアイ ソトープやカラム処理を要する。我々はプロモーターアッセイを応用した新 規アッセイ系を構築することで、ハイスループットな検出を可能とした。こ の系を用いて化合物スクリーニングを実施し、甲状腺ホルモン脱ヨード酵素 の新規調節因子の探索を行う。【方法】 pNL1.1ベクターにD1、D2、D3のプロ モーター配列をクローニングし、これらを導入したHEK293T 細胞を384 ウエ ルプレートに播種した。臨床応用されている薬剤の化合物ライブラリー $(2560$ 種類）を使用し、添加 24 時間後に検出試薬を加えて発光強度を測定した。【結 果】まず全化合物に対し一次スクリーニングを行い、陽性化合物に対してはプ ロモーター特異性・再現性の確認と細胞毒性の除外のための二次スクリーニ ングも行った。正に制御するヒット化合物（D1：6個、D2：34個、D3：5個） と負に制御するとット化合物（D1：5個、D2：5個、D3：2個）を確定した が、D2を正に制御するヒット化合物には既知のアドレナリン受容体作動薬が 24 個含まれていた。【考察】甲状腺ホルモン脱ヨード酵素との関連が未報告の ヒット化合物を複数得た。解析を進めるにあたり、ヒット化合物が臨床応用さ れている薬剤であることを活かし、レトロスペクティブコホート研究と統合さ せる手法を考案した。当院通院患者のヒット化合物服薬前後の甲状腺機能を解 析中であり、合わせて報告する。

\section{2-9-8当院における盰障害を呈したバセドウ病患者の臨 床的特徵と重症化関連因子の検討}

早川 惠理、山下 大翔、佐伯 浩介、杉山 徹 武蔵野赤十字病院

【背景】バセドウ病は甲状腺機能の程度によらない多彩な臟器障害を呈し、致 命的になることもある。【目的】当院における肝障害を呈したバセドウ病の臨 床的特徴を解析し、重症化に関連した要因を検討した。対象と方法】2013年 4 月〜2019年 3 月に来院した未治療バセドウ病患者 237 例を対象とした。肝障 害(AST・ALT・ $\gamma$ GTP 上昇)群の抽出は、バセドウ病治療開始後に肝障害が 改善したことを確認しえた症例のみとし、治療開始後の悪化例や治療後も改 善を認めなかった症例は除外した。【結果と考察】237例中95例 (40.1\%)で肝 障害がみられ、正常群 (142 例; 年齢50.6 17 歳、女性 110 例 (77.5\%)) と比較し、 肝障害群(年龄 $49.5 \pm 16$ 歲、女性 80 例 $(84.2 \%)$ )でやや女性が多い傾向にあった が、その他身体所見を含め有意差はなかった。肝障害群では心拍数が有意に

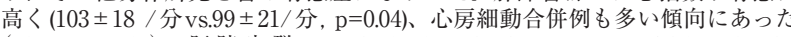
(10.5\%vs.7.7\%)。肝障害群でFT3(16 $\pm 9 \mathrm{vs} .12 \pm 8 \mathrm{pg} / \mathrm{mL}) 、 \mathrm{FT} 4(2.9 \pm 1.0 \mathrm{vs} .2 .5$ $\pm 1.0 \mathrm{ng} / \mathrm{dL}) 、$ サイログロブリン $(\mathrm{Tg})(191 \pm 276 \mathrm{vs} .88 \pm 138 \mathrm{ng} / \mathrm{mL})$ が有意に 高く(いずれも $\mathrm{p}<0.01) 、$ 盰障害合併の有無に甲状腺機能が関連していること が示唆されたが、肝障害が比較的速やかに改善した軽症例と 3 か月以上遷延し た重症例とを比較すると FT3・FT4・Tg值に有意差はなかった。肝障害の改 善期間に関与する項目としては、高齢 $(\mathrm{r}=0.32, \mathrm{p}<0.01)$ であり初診時のTSHが 低い $(\mathrm{r}=0.21, \mathrm{p}=0.04)$ ほど肝障害が遷延していた。また AST・ALT值は肝障害 の改善期間と相関がみられなかったが、 $\gamma \mathrm{GTP}(\mathrm{r}=0.23, \mathrm{p}<0.01)$ と ALP $(\mathrm{r}=0.53$, $\mathrm{p}=0.02)$ は有意な相関を認め、この両者が高い症例には注意を要すると考え られた。また甲状腺径が大きいほど肝機能の改善に期間を要するという相関 $(\mathrm{r}=0.53, \mathrm{p}=0.02)$ も認めた。

\section{2-9-10 抗PD-1 抗体による甲状腺機能異常の発症機序： 新規自己抗体の意義}

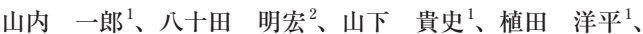

藤井 寿人 1 、田浦 大輔 ${ }^{1}$ 、曽根 正勝 ${ }^{1}$ 、稲坦 暢也

${ }^{1}$ 京都大学大学院 医学研究科 糖尿病 - 内分泌 - 栄養内科学、 ${ }^{2}$ 国立病院機構 京都医療センター 臨床研究センター

【背景】免疫チェックポイント阻害薬である抗PD-1抗体による甲状腺機能異 常 (甲状腺irAE) の発症機序は不明である。我々は甲状腺 irAE発症群では生 存期間が長く、この関連は肺癌では認められるが、悪性黒色腫では認められな いことを報告している。この原発巣による相違に着目し、甲状腺関連抗原に対 する自己抗体が産生され、この抗原が原発巣に発現している場合に抗腄瘁効 果を認めると仮説を立てた。【方法】 HEK293T細胞にて候補蛋白（NKX2-1、 PAX8、FOXE1、HHEX) を強制発現させ、ライセートと甲状腺 $\operatorname{irAE}$ 発症 3 例の血清を用いて共免疫沈降を行い、回収した IgG分画をウェスタンブロット 法にて解析した。【結果】健常人血清と比較して、症例 1 ではFOXE1、症例 2 ではPAX8、症例3ではPAX8、FOXE1のバンドの増強を認め、血清中にそれ ぞれを認識する抗体が存在することを明らかにした。症例 3 の血清 $200 \mu 1$ 由来 の IgG分画をC57BL/6 マウスに 2 週毎に投与し、4 週後に甲状腺組織を採取し て観察したが、有意な変化は認めなかった。【結論】甲状腺 $\operatorname{irAE}$ 発症患者血清 よりFOXE1、PAX8に対する自己抗体を新規に同定した。実験系の制限によ 万可能性もあるが、抗体自身の組織障害性は認めなかった。我々は甲状腺組織 がPD-L1に加え PD-L 2 も発現していることを以前に報告しており、甲状腺は 抗PD-1抗体による PD-1経路の阻害により免疫恒常性が破綻しやすく、その 結果として甲状腺由来の自己抗体の産生が起こると考えている。甲状腺 irAE を発症した症例は予後良好であることから、その発症機序に迫ることはバイオ マーカー探索にも寄与するものであり報告する。

\section{2-9-12 TRHKOマウスの網膜形態とS/Mオプシン発現量 の検討}

齊藤 千真 ${ }^{1}$ 、堀口 和彦 ${ }^{1} 、$ Buyandalai Battsetseg ${ }^{1}$ 、錦戸 彩加 ${ }^{1}$, 岡村 孝志 ${ }^{1}$ 石田 恵美 ${ }^{1} 、$ 松本 俊一 ${ }^{1}$ 、吉野 聡 $^{1}$ 、中島 康代 ${ }^{1} 、$ 山田 英二郎 ${ }^{1}$ 、秋山 英雄 ${ }^{2}$ 、山田 正信 $^{1}$

${ }^{1}$ 群馬大学 大学院 医学系研究科 内分泌代謝内科学、 ${ }^{2}$ 群馬大学 大学院 医学 系研究科 眼科学

【目的】マウスの網膜錐体視細胞には光感受性物質である short wavelength (S) opsin と medium wavelength (M)opsinがある。甲状腺ホルモンは、錐体 視細胞の分化に関与し、M opsinの発現を促進し、S opsinの発現を抑制する。 そのため、甲状腺機能低下症モデルマウスの発達期では M opsinの発現が遅 れ、 S opsinの発現が充進する。今回、我々はTRH欠損マウス (TRHKO) の 網膜形態と S/M opsin 発現を検討した。【方法】生後30日目（P30）の網膜 形態をHE染色によって、野生型（WT）とTRHKOで比較した。P12、P17 P30のWTと TRHKO及びTR $\beta^{\Delta 337 \mathrm{~T} / \Delta 337 \mathrm{~T}}$ マウスの網膜から mRNAを抽出し、 リアルタイム PCRにて $\mathrm{S} / \mathrm{M}$ opsinの遺伝子発現量、免疫組織染色により $\mathrm{S} / \mathrm{M}$ opsinの蛋白発現を検討した。【結果】1)HE染色では、WTと TRHKOの網膜

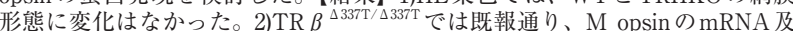
び蛋白質発現は確認できなかったが、TRHKOではWTと同様の発現を示し た 3) TR $\beta^{\Delta 337 \mathrm{~T} / \Delta 337}$ でS opsin の mRNA、蛋白質発現量はWTより増加して いたが、TRHKOではWTと同様の発現を示した。【結語】中枢性甲状腺機能 低下症を示す TRHKO ではS/Mオプシンの発達障害は認めず、その他の甲状 腺機能低下症モデルマウスとは異なっていた。TRHKOは、それらのマウスと 比較し、甲状腺機能障害が軽度であることが原因と考えられた。 


\section{2-9-13 甲状腺微小癌を併存したバセドウ病 12 症例に対す} るアイソトープ治療後の転帰と腫瘍サイズ変化

西原 永潤、南方 瑞穂、正木 ゆづき、羽田 幹子、中村 友彦、 高坂 和芳、笠原 俊彦、工藤 工、伊藤 充、鄉司 克己、 深田 修司、西川 光重、中村 浩淑、宮内 昭

隈病院

【はじめに】甲状腺癌併存時のバセドウ病に対し、アイソトープ治療（RIT） は一般的に禁忌である。しかし、バセドウ病RIT後の症例で、治療前から微 小癌併存例を時々経験する。これら症例の転帰と、RIT前後の微小癌の腫瘍体 積変化を 1 年あたりの doubling 回数（DR）にて評価した。【対象と方法】対象 は、2000年から 2017 年にRIT施行したバセドウ病患者のうち、以下の条件を 満たす 12 名。RIT前に超音波検查で $10 \mathrm{~mm}$ 以下の腫瘍が存在、RIT後も超音 波検査で腫瘍をフォローでき、経過中に穿刺吸引細胞診で同部位から乳頭癌が 同定された。RIT 直前からフォロー後の腫瘍体積変化は、 DR $<-0.1$ : 縮小、 -0.1 $\leqq \mathrm{DR} \leqq 0.1$ : 不変、 $0.1<\mathrm{DR} \leqq 0.5$ : 緩徐な増大、 $0.5<\mathrm{DR}$ :急速増大と判定。【結果】 RIT 時の年齢46(39-74)歳、RI投与量は 13 (4-13)mCi: 中央值(範囲)。フォロー 期間は3.9 (0.5-11.5)年で、フォロー時の甲状腺機能は充進2名、正常(LT4補充 含む) 10 名であった。腫瘍最大径は、RIT前 7 (5-10)mm、フォロー時8 (4-18) $\mathrm{mm}$ 。経過中 5 名は手術施行され(手術理由: 腫瘍増大 3 名、根治希望 2 名)、1 名に頸部リンパ節転移を認めた。手術例の腫瘍体積は急速増大 1 名、緩徐な増 大 3 名、不恋 1 名。一方、非手術経過観察 7 名の腫瘍体積は緩徐な増大 2 名、不 変 2 名、縮小 3 名であった。【考察】手術例では腫瘍体積増大が多い。ただし、 急速増大例の腫瘍最大径は $2 \mathrm{~mm}$ 増大で、リンパ節転移なく臨床的に問題ない レベルであり、フォロー期間が短い(1.4 年)のが影響した可能性がある。微小 癌併存のバセドウ病への RIT後は、症例の半数は腫瘍体積不変か縮小するこ とも念頭に置いたフォローが望まれる。

\section{2-9-15 小児および若年者甲状腺分化癌における遠隔転移 の危険因子の検討}

杉野 公則、長椖 充二、北川 亘、友田 智哲、伊藤 公一 伊藤病院 外科

【はじめに】小児执よび若年者甲状腺分化癌は進行例が多いが、予後良好であ るしかし、成人例に比して再発が多く、特に遠隔転移が多いことが知られて いる。さらに、少ない原病死例は遠隔転移例である。小児および若年者甲状腺 分化癌症例に拈ける遠隔転移例の治療結果と危険因子を検討した。【対象と方 法】1979年から 2014年の間に当院で初回手術を行った 20 歳以下の甲状腺分化 癌症例 288 例を対象とした。女性 251 例、15歳以下 70 例、乳頭癌 250 例であ た。無遠隔転移生存率(DMFS)を primary endpointとし、Kaplan-Meir法で求 め、臨床因子ごとにlog-rank法で検定した。多変量解析はCoxの Proportional hazard modelで行った。遠隔転移に関与する因子からリスク分類を試みた。 【結果】観察期間中に遠隔転移を 36 例 $(12.5 \%$ 、同時性 21 例、異時性 15 例) に認めた。死亡例は 3 名に認め、全例同時性遠隔転移例であった。10年および 20 年DMFSは $89 \%$ 、87\%であった。33例に放射性ヨウ素(RAI)内用療法を行 い、CR 7例、PR 15例、SD 9例、PD 2例であった。奏効率 $67 \%$ 、病勢コント ロール率 $94 \%$ であった。多変量解析によるDMFSに関与する有意な危険因子 は性別、cN1、ETE、NMLNsであった。危険因子の多寡で、以下の3つのカ テゴリーに分類した。低危険度（L群）:なし、中等度 (I 群)：1個、高危険度 (H群)：2 個以上。20年DMFSはそれぞれL 群 $98.7 \%$ 、I 群 $94.9 \%$ 、H 群 $55.5 \%$ であった【結論】遠隔転移はRAI内用療法に上り比較的良好にコントロール されていたが、死亡例も認められた。一方、2個以上の危険因子を有する症例 では遠隔転移の発生が有意に多く、慎重な経過観察が望まれる。

\section{2-9-17 バセドウ病眼症におけるMRI T1 mappingの有用 性}

松澤 和彦 ${ }^{1} 、$ 伊澤 正一郎 ${ }^{1}$ 、加藤 亜由美 ${ }^{2} 、$ 宮崎 大 $^{3}$ 、

黒崎 雅道 ${ }^{4}$ 、哚谷 健二 ${ }^{1}$ 、松本 和久 ${ }^{1}$ 、庄司 恭子 ${ }^{1}$ 、大倉 毅 ${ }^{1}$ 、 吉田 明雄 ${ }^{5}$ 、谷口 晋一 ${ }^{6}$ 、山本 一博

${ }^{1}$ 鳥取大学 医学部 病態情報内科学、 ${ }^{2}$ 鳥取大学医学部画像診断治療学分野、 ${ }^{3}$ 鳥取大学医学部視覚病態学分野、 ${ }^{4}$ 鳥取大学医学部脳神経外科学分野、 ${ }^{5}$ 鳥 取大学医学部大学院再生医療学分野、 ${ }^{6}$ 鳥取大学医学部地域医療学講座

【背景】バセドウ病眼症の複視はQOLを阻害する重要因子であるが、ステロイ ド療法で最も効果がそしい症状である。外眼筋線維化がステロイド治療抵抗性 複視となることが考えられている。一方 MRIの新たな撮像法として組織線維 化を定量的に評価するMRI T1mapping(T1map)が様々な蔵器で応用されてい る。【目的】治療抵抗性複視症例の外眼筋 T 1 map の特徵を見出す。【方法】過 去に複視を有し、ステロイドパルス療法で複視消失症例（I群：20例）と複視 残存症例（D群：14例）の外眼筋 T $1 \mathrm{map}$ 信号強度を比較した。眼科疾患、自 己免疫性甲状腺疾患の無い症例（C群：33例）とした。【結果】患者背景（I群 $/ \mathrm{D}$ 群/C群) は年齢 $53 \pm 14 / 61 \pm 10 / 59 \pm 19$ (歳)、男女比 $6 / 14 、 6 / 8 、 20 / 13$ CAS1.0 $\pm 0.9 / 1.1 \pm 1.1 / 0$ 、TSH $2.1 \pm 2.8 / 1.8 \pm 1.3 / 2.5 \pm 1.8(\mu \mathrm{IU} / \mathrm{mL})$, FT4 1.3 $\pm 0.3 / 1.5 \pm 0.3 / 1.2 \pm 0.2(\mathrm{ng} / \mathrm{dL})$, TRAb3rd $7.9 \pm 9.6 / 5.6 \pm 4.6 / 0.8 \pm 0.3(\mathrm{IU} / \mathrm{L})$. TSAb $640 \pm 501 / 674 \pm 865$ /N.A (\%)であった。T1map信号強度（左右平均）は 下直筋 $1720 \pm 275 / 1433 \pm 199 / 1712 \pm 275(\mathrm{~m} / \mathrm{s})$ 、内側直筋 $1930 \pm 192 / 1667 \pm$ 183/1862 $\pm 358(\mathrm{~m} / \mathrm{s})$ とD群で有意に低值であった。【考察】線維化の T1map 信号強度は高値とされているが、脂肪を含む線維化は著明な低信号となる報告 がある。眼窩部は脂肪が多く、D群は脂肪を含む線維化を生じ、信号強度が低 下している可能性を考えた。ステロイド治療を実施時に評価することで複視に 対する効果の予測が期待される。

\section{2-9-14 BRAF遺伝子変異を有する甲状腺機能性乳頭癌の 一例}

新海 信介 ${ }^{1}$ 、大場 健司 ${ }^{1} 、$ 佐々木 茂和 ${ }^{1}$ 、西野 暢彦 $^{2} 、$ 松下 明生 ${ }^{1}$ 、黑田 豪 ${ }^{1}$ 、酒井 勇輝 ${ }^{1}$ 、覚道 健一 ${ }^{3}$ 、沖 隆 ${ }^{1}$ 浜松医科大学 医学部附属病院 内分泌代謝内科、 ${ }^{2}$ 新風会丸山病院 外科、 3 近畿大学医学部奈良病院中央臨床検査部病理診断科、 ${ }^{4}$ 浜松医科大学 地域 家庭医療学講座

【背景】機能性甲状腺癌は甲状腺ホルモン産生能を有する癌と定義され、甲状 腺腫瘍における頻度は $0.1 \%$ 未満と極めて稀である。【症例】 48 歳、男性。X-1 年 12 月、人間ドックの甲状腺エコーで右葉に $2 \mathrm{~cm}$ 大の腫瘤を指摘され、 $\mathrm{X}$ 年 1 月に前医を受診した。穿刺吸引細胞診は悪性（乳頭癌疑い）に相当したため、 手術加療目的でX年 3 月に当院を紹介受診した。TSH $0.01 \mu \mathrm{IU} / \mathrm{ml} 、 \mathrm{FT} 34.3$ $\mathrm{pg} / \mathrm{ml}$ 、FT4 $1.8 \mathrm{ng} / \mathrm{dl}$ 、Tg $62.1 \mathrm{ng} / \mathrm{ml}$ 、TRAb $<0.8 \mathrm{IU} / \mathrm{l}$ 、TSAb $119 \%$ 。 コーでは右葉上極に $25 \times 22 \times 12 \mathrm{~mm}$ の低輝度で血流豊富な充実性腫瘤を認め た。 ${ }^{99} \mathrm{~T} \mathrm{Tc}$ シンチグラフィでは結節に一致した強い集積と左葉の集積低下を認 めた。X年4月に甲状腺全摘、中央扔よび右外側頸部リンパ節郭清術 D2a を施 行し、甲状腺乳頭癌（T2Ex0N1bM0、Stage IVA）と診断した。レボチロキ シン補充により甲状腺機能は安定した。腫瘍部は通常型の乳頭癌で、一部に高 細胞亜型を疑う所見を認めた。【方法】1. 自験例のホルマリン固定パラフィン 包埋標本からDNAを抽出し、TSHR、GNAS、BRAF、RAS、TERT 遺伝子変異 をサンガー法で解析した。2.同様の症例をPubmedで検索し、年齢・性別・病 理組織型·体細胞突然変異の有無について検討した。【結果】1.自験例の解析 でBRAF連伝子変異（p.V600E）のみを同定した。2.遺伝子異常を検討された 機能性甲状腺癌の報告は 16 例と少なく、TSHRのみの変異例を 11 例、TSHR と RAS 変異の合併例を 1 例で確認した。【結語】稀な機能性甲状腺癌の一例を経 験した。文献検索した限りではBRAFV600E遺伝子変異を確認し得た最初の症 例と考えられた。

\section{2-9-16 眼科的治療が必要なバセドウ病眼症の頻度}

工藤 工 ${ }^{1}$ 、南方 瑞穂 ${ }^{1} 、$ 正木 ゆづき ${ }^{1} 、$ 羽田 幹子 ${ }^{1} 、$ 高橋 佐和子 ${ }^{1}$ 、神谷 麻衣 $^{1}$ 、高坂 和芳 ${ }^{1}$ 、淡野 宏輔 ${ }^{1}$ 、 笠原 俊彦 1 、郷司 克己 ${ }^{1} 、$ 深田 修司 ${ }^{1} 、$ 西原 永潤 ${ }^{1} 、$ 伊藤 充 $^{1} 、$ 西川 光重 ${ }^{1}$ 、中村 浩淑 ${ }^{1}$ 、宮内 昭 ${ }^{2}$

${ }^{1}$ 隈病院 内科、 ${ }^{2}$ 隈病院 外科

【初めに】バセドウ病の $25 \sim 50 \% に$ 眼症を発症するといわれ、重症例ではステ ロイド剤の局所・全身治療等が行われている。しかし、実際に治療を必要とす る重症眼症の発症率は明確ではない。【目的】バセドウ病治療中にステロイド パルス治療・局所投与、手術などの眼科的治療が必要となる割合を算出する。 【対象と方法】2015年から 2018年の初診患者で、TRAbが陽性で当院でバセド ウ病と診断し治療を開始した 3439 名。内、眼科専門医に検查・治療を依頼し た104名の診療記録から実施された治療を後ろ向きに検討した。【結果】ステ ロイドパルス療法は 29 名 $(0.84 \%$ )、ステロイド局所注射は 24 名 $(0.70 \%)$ 、眼 科手術が 2 名(内反症手術 1 名・外眼筋短縮術 1 名)であった。初診時に眼症が あったものは 90 名で、内、ステロイドパルス療法のみ 20 名、局所注射の併用 が4名、局所注射のみ 17 名、眼科手術 1 名。一方、初診時に眼症状がなく後か ら出現したのは14名 (2名がアイソトープ治療後)で、ステロイドパルス療法の み 5 名(アイソトープ治療後が 1 名)、局所注射のみ 3 名、眼科手術 1 名であっ た。初診時に症状があった $48 \%$ では経過観察のみで改善していたが、後から 症状が出現した症例では $71 \% に$ 眼科治療が行われていた。【考察】バセドウ病 初診患者において、治療対象となった眼症は1.5\%であったが、治療を针めた が希望で経過観察となった症例もあり重症眼症の発生頻度はより高い可能性が ある。【結語】今回の検討で、専門病院で新規に診断したバセドウ病患者のう ち眼科的治療を要する重症眼症の合併は少数であり、その大半が受診時に症状 が出現していたことが示された。

\section{2-9-18 小児期発症バセドウ病におけるSIGLEC1 mRNA 定量の検討}

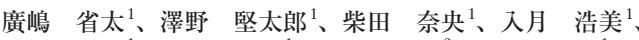
佐々木 直 ${ }^{1}$ 、小川 洋平 ${ }^{1}$ 、橋本 貢士 ${ }^{2}$ 、長崎 啓祐 ${ }^{1}$ 新潟大学医歯学総合病院 小览科、 ${ }^{2}$ 獨協医科大学埼玉医療センター 糖尿病 内分泌・血液内科

【背景】SIGLEC1は、成人バセドウ病の再燃を高精度に予測する新しいバイオ マーカーとして、臨床応用が期待されている。小児期発症バセドウ病（以下本 症）は寛解率が低く、難治例が多いとされているが、小児におけるSIGLEC1 の意義は明らかになっていない【目的】本症におけるSIGLEC1の特性を明 らかにする。【方法】対象は当院通院中の初診時 18 歳未満発症のバセドウ病 35 人。 2019 年 5 月 -9 月に定期受診時の白血球中 SIGLEC1 mRNA コピー数(以下 SIGLEC1 值)を測定した。SIGLEC1值と治療前、検査時TRAb 值, FT4值との 関連性を検討した。また検查時の MMIの 1 日投与量により $<5 \mathrm{mg}$ (少量群)、 MMI 5-12.5mg (中間群)、MMI $\geqq 15 \mathrm{mg}$ (高用量群) に分けSIGLEC1值、 TRAb 值について比較検討した。【結果】初診時年齢の中央值(範囲) 12.3 歳(3.1 - 17.8)、男性7名女性 28 名。SIGLEC1 の中央值 (四分位範囲)は 258.8 (179.4429.0)であり、258.9を再燃のカットオフ值とすると $43 \%$ がこれを上回った。検 查時TRAb 值と SIGLEC 1 值は弱い正の関連 $(r=0.28, \mathrm{P}=0.11)$ を認めた。少量 群 $(\mathrm{n}=8)$ 、中間群 $(\mathrm{n}=14)$ 、高用量群 $(\mathrm{n}=8)$ のSIGLEC1値の中央値（四分位範 囲) は、185.1 (164.8 - 213.9)、275.1 (167.7 - 766.9)、405.9 (336 - 977.3) で あり、少量群と高用量群に执いて有意な差を認めた。【考察・結語】本症では、 成人に比して SIGLEC1高值を示す症例が多く、難治性を示唆する結果であっ た。高用量群は少量群と比較してTRAb值、SIGLEC1值が有意に高く、寛解 のしづらさを示唆している可能性が示唆された。本症おいてもSIGLEC1值が 寛解の指標になるか否か前向きに追跡調査を行う予定である。 


\section{3-4-1}

\section{インスリン分泌能が完全に枯渇した 1 型糖尿病にお} けるイプラブリフロジンの効果と導入手法の検討

齊藤 智之 ${ }^{1}$ 、山田 穂高 ${ }^{1,2}$ 、浅野 智子 ${ }^{1}$ 、石丸 安明 ${ }^{1}$ ${ }^{1}$ 熊谷ディアベテスクリニック 糖尿病内科、 ${ }^{2}$ 自治医科大学附属さいたま医 療センター 内分泌代謝科

【目的】インスリン分泌能が完全に枯渴した1型糖尿病を対象として、イプラ グリフロジンの効果と安全性、導入手法を検討した。

【方法】血中Cペプチド $0.1 \mathrm{ng} / \mathrm{ml}$ 未満の 1 型糖尿病 24 例（男性 14 例、女性 10 例：年齢 $50.5 \pm 14.8$ 歳; mean $\pm \mathrm{SD}$ ) を対象とし、インスリン投与量を変更せず に、イプラグリフロジン $50 \mathrm{mg}$ を追加投与し、追加前、1 1 个月後、6 月月後に評 価を行った。

【結果】 $\mathrm{HbA} 1 \mathrm{c}$ は追加前 $8.9 \pm 0.2 \%(\operatorname{mean} \pm \mathrm{SE})$ から、6か月後 $7.9 \pm 0.2 \%$ $(\mathrm{P}<0.001)$ と、直近 2 週間の早朝空腹時 $\mathrm{SMBG}$ 最低值と最高值は追加前 $116 \pm$ 10、 $234 \pm 11 \mathrm{mg} / \mathrm{dl}$ か ら、6か月後 $76 \pm 5(\mathrm{P}<0.01) 、 171 \pm 9 \mathrm{mg} / \mathrm{dl} \quad(\mathrm{P}<0.001)$ と、それぞれ有意に低下した。インスリン量は 6 か月後に平均 1.4 単位 $(2.5 \%)$ 減少した $(\mathrm{P}<0.05)$ 。体重、BMIも6か月後に有意に低下した $(\mathrm{P}<0.001)$ 。尿 ケトン体は 2 例で見られたが、継続して出現することは無く、尿比重、BUN、 eGFRは6か月間で有意な変化は認めなかった。ケトアシドーシス、重症低血 糖などは見られなかった

【考察】インスリン分泌能が完全に枯渇した 1 型糖尿病においてもイプラグリ フロジンの追加投与は効果的であった。従来の臨床研究では、追加投与時に $15 \%$ のインスリン減量が推奨されているが、本研究ではインスリン分泌能完 全枯渴症例であったため、敢えてインスリンの減量を行わなかった。 HbAlc は平均 $1.0 \%$ の低下が見られ、従来の臨床研究より低下効果は高く、インスリ ン減少量も $2.5 \%$ と少なく、また重症副作用も見られなかった。インスリン分 泌能が完全に枯渇した症例では、イプラグリフロジン追加投与時のインスリン 減量幅は個別症例毎に判断すべきと考えられた。

\section{3-4-3 ニボルマブ投与後発症 1 型糖尿病症例における剖 検膵の組織学的検討}

宇野 彩、長岡 沙織、博多 紗弓、佐山 晧一、上中 理香子 国家公務員共済組合連合会 大手前病院 代謝・内分泌内科

【症例】56歳、男性。38歳時に糖尿病と診断、経口血糖降下薬にて加療されて いた41歳時ホジキンリンパ腫と診断、ABVD療法などの化学療法、放射線 療法の後、X年 4 月ニボルマブ $(\mathrm{NIV})$ による治療を開始された。 $\mathrm{X}$ 年 7 月初旬倦 总感、口渇を自覚。同月 10 日 NIV6回目投与時に甲状腺機能立進を認め、同月 24 日当科紹介受診。検查にて糖尿病ケトーシスを認めたため入院のうえ強化 インスリン療法を開始。glucagon負荷試験にて内因性インスリン分泌能の枯 渇を認め、1型糖尿病の併発と診断した。GAD抗体、抗IA-2抗体は共に陰性。 抗 TPO抗体、抗 Tg抗体は陽性であった。第 13 病日には甲状腺機能低下を認 め橋本病と診断、甲状腺ホルモン補充療法を開始し退院。NIV投与を再開し計 21 回投与。その後、胸椎転移を認めX+1年 6 月にペムブロリズマブ投与開始 するも病勢増悪、同年 11 月には意識障害を来し入院。CT検査では多発結節性 陰影、縦隔リンパ節の腫大を認めた。第16病日呼吸不全急性増悪のため死亡 剖検を施行した。得られた膵組織を用い免疫組織学的検討を行なった。解析し た膵島はのべ 114 個。インスリン陽性細胞を認めた膵島は 54 個 $(47.4 \%)$ であっ た。インスリン陽性細胞残存膵島の $65.0 \%$ にD 3 陽性 T細胞の浸潤を認めた CD8 陽性細胞、CD4 陽性細胞双方の浸潤を認め、CD4陽性細胞浸潤は34.8\%の 膵島に認められた。CD68 陽性 M $\phi$ の浸潤は $40.5 \%$ の膵島に認めた。また、外 分泌領域には CD163 陽性 M2 M $\phi$ の強い浸潤を認め、それは膵島内にも認めら れた。【考察】今回の検討では制御性 T細胞や抗炎症性に作用する $\mathrm{M} 2 \mathrm{M} \phi$ の膵 島内および膵外分泌領域への浸潤を認めた。原疾患の病勢が膵内における免疫 環境の変化に影響を及ほしている可能性が考えられた。

\section{3-4-5２型糖尿病における HbA1c変動性と持続血糖モ二 タリングで評価した血糖日内変動との関係}

得津 明美、岡田 洋右、鳥本 桂一、田中 良哉 産業医科大学病院 第 1 内科学講座

【背景・目的】 $\mathrm{HbAlc}$ の変動は HbAlcの平均值と独立して血管合併症による 死亡と関連することが報告されている。しかし、HbAlc 変動性の意義につい ては不詳である。今回、Flash glucose monitoring (FGM) を用いて血糖日内変 動を評価し、HbAlc 変動性との関連について検討した。

【方法】2018年9月から2019年1月に、外来でFGMを施行した 2 型糖尿病患 者で、治療内容に変更がない26例を対象として、後ろ向きに検討を行った。 FGMのデータは連続した7日間を使用した。主要評価項目は、6か月間の $\mathrm{HbAlc} \mathrm{SD}$ (標準偏差) と関連する因子、副次評価項目はHbAlc Mean（平 均）と関連する因子とした。

【結果】1) 患者背景は男/女 $14 / 12$ 人、年齢 68.5 歳、BMI $24.3 \mathrm{~kg} / \mathrm{m}^{2} 、 \mathrm{HbAlc}$ $6.7 \%$ ２） HbA1c SD は低血糖時間、LGBI（low blood glucose index）と正相 関し、最低血糖値と負相関した。3) 多変量解析では、HbA1c SDに影響を与え る因子は最低血糖值であった。4) 低血糖が生じた群ではHbA1c SDが有意に 高值 $(\mathrm{p}=0.001)$ であった。5) HbAlc Mean は平均血糖、SD、最大血糖值、血糖 180 以上の時間、MODD (the mean of daily difference)、HBGI (high blood glucose index）と正相関し、TIR（time in range）と負相関した。6) 多変量 解析で薬剤との相関は認められず、各薬剤の有無でHbAlc SDの差はなかっ t。

【結語】慢性高血糖と $\mathrm{HbA1c}$ 平均值が関連することは既に報告されているが、 今回初めて低血糖と HAlcの変動性が関連することが明らかとなった。 HbAlc の変動性は低血糖リスクを反映しており、心血管死のリスクと関連する可能性 が示唆された。HbAlcの変動が大きい症例は、低血糖の有無を評価し、投与 薬剤を含めた治療内容の再検討をするべきである。

\section{3-4-2フラッシュブルコースモニタリングにおけるTIR の有用性に関する検討}

浦上 達彦、桑原 怜未、吉田 圭、峯 佑介、鈴木 潤一、

阿部百合子

日本大学医学部小览科

【目的】小児 1 型糖尿病におけるフラッシュグルコースモニタリング（FGM） の目標範囲時間 (Time in range:TIR) の有用性について検討する。【方法】 対象は小児1型糖尿病71例（男/女 $33 / 38$ 、年齢 $13.9 \pm 4.9$ 歳、治療法 MDI CSII $=51 / 20)$ である。この対象で28日間に記録されたFGMの記録により、皮 下ブドウ糖 $(\mathrm{SG})$ 值 $70 \sim 180 \mathrm{mg} / \mathrm{dL}$ の TIR、 $70 \mathrm{mg} / \mathrm{dL}$ 未满の time below range:TBR、 $181 \mathrm{mg} / \mathrm{dL}$ 以上の time above range:TARの時間頻度を求め、平 均SG值から推定される $\mathrm{HbA} 1 \mathrm{c}$ (eA1c) と検查室で同時に測定した HbA1c 值 との相関について検討した。【結果】1) 対象のSG、eA1c、 $\mathrm{HbA1c}$ の平均值 は各 $165.5 \pm 24.3 \mathrm{mg} / \mathrm{dL} 、 7,4 \pm 0.9 \% 、 7.5 \pm 0.9 \%$ であった。 eAlc と HbAlcは $\mathrm{r}=0.979(\mathrm{P}<0.0001)$ の有意な相関を示した（従って以下の検討は eA1cのみ とする)。2) 対象の TIR、TBR、TARの平均時間頻度は各 $49.3 \pm 11.8 \% 、 11.6$ $\pm 5.8 \% 、 39.2 \pm 12.3 \%$ であった。TIR、TARはeA1cと $\mathrm{r}=-0.831 、 \mathrm{r}=0.895$ の有意な相関（各 $\mathrm{P}<0.0001 ）$ を示したが、TBRでは有意な相関はなかった。 3) 相関散布図の近似式から求めた eAlc $7.0 \%$ に相当する TIR、TARの頻度 は各 $53.6 \% 、 34.4 \%$ であった。【考察】TIRのConsensus Recommendation (Battelino T. 2019) では、eA1c 7.0\%に相当する TIRの時間頻度は70\%とされ ている。しかし我々の検討では相当するTIRの時間頻度は $53.6 \%$ と低く、一方 eAlc $7.0 \%$ に相当するTARの時間頻度は $34.4 \%$ と高かった。小児 1 型糖尿病て は良好な $\mathrm{eAlc}(7.0 \%)$ を示していても、SG 值の変動幅が大きく食後の血糖上 昇が高いために、目標範囲内にSG值を保つことは困難であるとと思われた。 これには検討された欧米施設との治療、管理の質および食生活の相違が関係し ているかもしれない

\section{3-4-4 涙液中の糖尿病関連バイオマーカー測定による非 侵襲的糖尿病管理法の開発}

相原 允一 ${ }^{1} 、$ 窪田 直人 ${ }^{1} 、$ 宇佐美 彗 ${ }^{2} 、$ 陣内 秀昭 ${ }^{3} 、$ 相原 ${ }^{4}$ 、 山内 敏正 ${ }^{1}$ 、坂田 利弥 ${ }^{5}$ 、門脇 孝 $^{1}$

${ }^{1}$ 東京大学 医学部 糖尿病- 代謝内科、 ${ }^{2}$ 東京大学 高大接続研究開発セン 夕ー、 ${ }^{3}$ 陣内病院、 ${ }^{4}$ 東京大学 医学部 眼科学、 ${ }^{5}$ 東京大学 工学部

【背景/目的】糖尿病管理には血糖コントロールの把握が重要である。把握法 には血糖自己測定、皮下連続式グルコース測定、医療機関の採血検查などが用 いられるが、いずれも侵襲的手技を要する。糖尿病患者の涙液中の糖濃度 (涙 糖値) は高值であることが知られており、我々は非侵襲的に採取できる淚液に 注目し、涙液中の糖尿病関連バイオマーカーを検討し、非侵襲的な糖尿病管理 法の開発を行うこととした。

【方法/結果】(研究1) 非糖尿病被験者 10 名と糖尿病被験者 20 名を募集し、血 糖值と涙糖值を測定した。まず沪液中の潜血を確認し、涙糖值が高值示す沪 潜血陽性の検体を解析から除外した。非糖尿病被験者、糖尿病被験者ともに、 涙糖值は血糖值と概ね類似した日内変動を示した。線型混合モデル解析では、 血糖値と沪糖值は有意な相関 $(p<0.001)$ を認め、この相関関係は被験者毎に異 なっていた $(p<0.05)$ 。また HbAlc 值や食前/食後で調整後も血糖值と淚糖值は 有意な相関 $(p=0.002)$ を認めた。(研究 2 ) 糖尿病被験者 100 名を募集し、血液中 と涙液中のグリコアルブミン (GA) 值を測定した (99検体が適切に測定された)。 血液中と涙液中の GA 值は有意な相関関係 $(p<0.001)$ を認め、年齢、性別、腎 症、肥満で調整後も相関関係を認めた $(p<0.001)$

【考察】涙糖值は血液混入で偽性高值となるため、血液混入を防ぐ工夫が必要 である。また、個人毎にキャリブレーション等の対応が必要である。一方、涙 液中の GA 值は様々な因子を考虑に入れても血液中の GA 值と強い相関があり、 非侵襲的な糖尿病管理法に資するバイオマーカーであることが示唆された。

\section{3-4-6２型糖尿病患者における血中ケトン体濃度と無症 候性心筋虚血の頻度との関連}

眞鍋 健一、新谷 哲司、栗原 渉、岡本 唯、津留 伯耀、 増田 紘子、加藤 ひとみ、松原 史明、古川 慎哉 松山市民病院 内科

【背景】糖尿病患者に扔ける血中ケトン体の増加は、糖尿病性ケトアシドーシ スなど重篤な急性合併症を引きおこす。一方、ケトン体が効率のよいエネル ギー基質であるばかりでなく、ケトン体による心筋保護作用の可能性も近年 提唱されている。【目的】2型糖尿病患者における血中ケトン体濃度と無症候 性心筋虚血（以下、SMI)のとの関係を明らかにする。【方法】2010年7月から 2018年 12 月までに当院で糖尿病教育入院を行った心筋梗塞の既往を除外した 2 型糖尿病患者 541 例 (年齢 : $59.3 \pm 13.5$ 歳、䍜病期間 : $9.6 \pm 10.0$ 年、HbA1c : $9.4 \pm 2.3 \%$ 、男/女 : $351 / 190)$ を対象とした。運動負荷心電図で虚血陽性及び 評価不能な患者に対し冠動脈造影検査等を施行した。冠動脈に有意な狭窄が 見られた場合をSMI と診断し、一枝病変群 (1群)、二枝病変群 (2群)、三枝 病変群 (3群) にわけた。虚血が見られなかった群を対照群 (0群) とし、血 中ケトン体濃度と冠動脈病変の関係を調べた。【結果】541例中SMIは99例で あった。総ケトン体濃度は 0 群 $(\mathrm{n}=442)$ の $286.3 \pm 589.0 \mu \mathrm{mol} / \mathrm{l}$ と比較して、 それぞれ1群 $(\mathrm{n}=48)$ は $175.5 \pm 185.9 \mu \mathrm{mol} / \mathrm{l} 、 2$ 群 $(\mathrm{n}=31)$ は $145.3 \pm 233.6$ $\mu \mathrm{mol} / \mathrm{l} 、 3$ 群 $(\mathrm{n}=20)$ は $149.0 \pm 180.4 \mu \mathrm{mol} / 1$ であり、有意に低值であった $(\mathrm{p}=0.020 、 \mathrm{p}=0.018 、 \mathrm{p}=0.029)$ 【考察】2型糖尿病患者で、血中ケトン体濃度 が上昇することで心筋におけるケトン体酸化が増加し、心仕事効率が上昇し、 心筋収縮特性が改善することで、冠動脈の保護作用や心不全の進行を遅延させ る効果があるのかもしれない。 
03-4-8

SGLT2阻害薬投与による肝インスリンクリアラン ス増加と血中トリグリセリド・ßヒドロキシ酪酸 レベルの変化との関連について

松林 泰弘 ${ }^{1}$ 、吉田 明弘 ${ }^{2}$ 菅波 秀規 ${ }^{2}$ 藤原 和哉 ${ }^{1}$ 加来 浩平 ${ }^{3} 、$ 曽根 博仁

${ }^{1}$ 新潟大学医歯学総合病院 内分泌 - 代謝内科、 ${ }^{2}$ 興和株式会社、 ${ }^{3}$ 川崎医療福 祉大学

【目的】肥満と脂肪肝は肝インスリンクリアランス (Hepatic insulin clearance: HIC) を低下させ、慢性的な高インスリン血症の要因となることが知られてい る。SGLT2 阻害薬は 2 型糖尿病患者に执いて尿糖排泄促進を介し、肥满・高 インスリン血症を是正し、同時に血中ケトン体を上昇させることが知られて いる。我々はこれまでにSGLT2 阻害薬(トホグリフロジン: TOFO)投与によ り HIC は上昇し、この作用は高インスリン血症是正の一役を担っている可能 性を報告したが、本薬郕投与によるHICの変化と血中ケトン体( $\beta$-ヒドロキ シ酪酸: $\mathrm{BHB})$ やリグリセライド(TG)の変化との関連についての報告はなく、 この点につき今回検討を行った。【方法・対象】TOFO国内臨床治験デー夕を 併合。drug-naiveな2型糖尿病患者でプラセボ、TOFO 20mg、40mgのいず れかを $24 \mathrm{~W}$ 以上投与された 362 名を対象とした(M: $241, \mathrm{~F}: 121$ 、プラセボ: 56 , TOFO 20mg: 121, 40mg: 185)。HICは食事負荷試験から得られたC-peptide AUC 0-120 min / insulin AUC 0-120 minを指標として用い、TOFO投与後 の HIC と BHBを含む他の臨床指標の変化量の相関について検討を行った。結 果】 $24 \mathrm{~W}$ のTOFO投与でHIC、BHBは有意に上昇し一方で血中TGの有意な 低下を認めた。 HIC の変化と BHB 及び TG 変化との間には有意な相関関係が認 められた。結論】 TOFO投与によるHIC 上昇は高インスリン血症の是正と共 に血中 TG 低下と BHB 増加に有意に関連していた。血中 $T G$ は肝内脂肪量を反 映するとする報告もあり、脂肪肝改善に伴う HIC 上昇が、血中インスリンレ ベルの低下とBHB増加に一部寄与している可能性が示唆された。

\section{3-5-1Ｎr5a1遺伝子下垂体エンハンサー欠損マウスの解 析}

嶋 雄一1、鈴木 堅太郎 ${ }^{2}$

${ }^{1}$ 川崎医科大学 解剖学教室、 ${ }^{2}$ 和歌山県立医科大学 先端医学研究所 遺伝子制 御学研究部

下垂体前葉から分泌されるゴナドトロピンは、生殖腺間質の細胞に作用して性 ホルモンの産生を促進する。NR5A1（別名Ad4BP あるいはSF-1）は下垂体 のゴナドトロピン産生細胞に発現しており、黄体化ホルモンの $\beta$ サブユニッ 卜 $(\mathrm{LH} \beta)$ の発現制御因子であることが報告されているが、下垂体における NR5A1の分子機能の詳紐は明らかにされていない

我々はこれまでにNr5al 遺伝子の下垂体特異的な発現制御領域（エンハン サー）を同定している。そこで、下垂体に扔けるNR5A1の機能解明を目的と して、ゲノム編集によりNr5al遺伝子の下垂体エンハンサーを欠失するマウス を作出した。このマウスに打いては、胎仔期の精巣は正常位置に下降しウォル フ管の発達も正常であった。また外生殖器の形態にも異常は認められなかっ た。一方、成獣では精巣が矮小化して抢り、加えて精囊腺の消失や外生殖器の 登達不全が認められたここれらの結果から、胎仔期の男性ホルモン産生は下垂 体に依存せず、思春期以降の男性ホルモン産生は下垂体由来のゴナドトロピン に依存することが示唆された。一方、雌マウスの卵巣では黄体が観察されず、 排卵が障害されていると考えられた。以上の結果は、エンハンサー欠失マウス におけるLH分泌の低下を強く示唆した。しかしながら、下垂体の免疫染色の 結果、NR5A1およびFSH $\beta$ の発現は著しく低下していたもののLH $\beta$ の発現 は正常であり、LH $\beta$ の発現にNR5A1は必ずしも必須ではないことが示唆され た。以上の結果をもとに、下垂体ゴナドトロピン産生細胞におけるNR5A1の 機能を明らかにするため、現在さらに詳細な解析を行っている。

\section{3-5-3 MYRFは46,XXおよび46,XY DSDの原因遺伝子で ある}

増永 陽平 ${ }^{1} 、$ 濱中 耕平 ${ }^{2} 、$ 高田 篤 $^{2} 、$ 和田 友香 $^{3}$ 、福井 由宇子 $4^{4}$ 、 南 佐和子 ${ }^{5}$ 、樑見 真紀 4 、長谷川 奉延 ${ }^{6}$ 、松本 直通 ${ }^{2}$ 、緒方 勤 $^{1}$ ${ }^{1}$ 浜松医科大学 小児科、 ${ }^{2}$ 横浜市立大学大学院 医学研究科 遺伝学、 ${ }^{3}$ 成育医 療研究センター 新生児科、 ${ }^{4}$ 成育医療研究センター分子内分泌研究部、 5 和 歌山県立医科大学 産科婦人科学教室、6 慶應義塾大学 医学部 小児科学教室

【背景】性分化疾患(DSD)の原因は多岐にわたり、全エクソーム解析でも原因 遺伝子を特定できるのは $30-40 \%$ 程度にとどまる。特に、46,XX㧍よび $46, \mathrm{XY}$ DSD 両者の原因となる遺伝子は極めて稀である。

【DSD患者における病原性MYRF変異の同定】 DSD 26例に対する全エクンーム 解析により、de novo MYRF フレームシフトバリアントが3個同定された(一 卵性姉妹(症例 1 抢よび2)における $\mathrm{p}\left(\mathrm{S} 264 \mathrm{Afs}^{*} 8\right) 、 46, \mathrm{XY}$ DSD男児(症例3)にお ける $\mathrm{p}(\mathrm{P} 93 \mathrm{Rfs}$ *7)、46,XY DSD 男児(症例4)における リアントは健常人 2625 例で認められず、その変異頻度は、全遺伝子解析に対 するボンフェローニ補正後も有意であった $(p=1.95 \mathrm{E}-12)$ 。さらに、原因不明の DSD患者68例のMYRF 解析で、46,XY DSD男児(症例5)に拈いて p.(Q443P)が 同定された。

【臨床所見】症例 1 および2では卵巣・ミュラー管形成不全、症例 $3 \sim 5$ では外 性器異常(尿道下裂、停留精巣、小除荎) が認められた。症例 4 では左横隔膜へ ルニアと発達遅滞も認められた。

[MYRF 発現パターン】胎児性腺に打ける single cell RNA sequencingにより 体腔上皮(CE) およびCE由来細胞 (CEDC) では、男女共に MYRF が高発現であ ることが判明した。

【考察】本研究により、MYRF が46,XX㧍よび46,XY DSDの新規原因遺伝子で あることが示唆される。症例1〜5に执けるDSDはCE/CEDCの增殖・遊走異 常、上皮間葉相互作用障害により説明でき、MYRF は性腺・性管原基の分化 発達に関与することが考えられる。

\section{3-4-9 糖尿病性腎症重症化高リスク群の背景因子の検討}

千葉 拓 ${ }^{1} 、$ 大久保 化 ${ }^{2}$ 小田 知靖 ${ }^{1}$ 橋本 朋子 ${ }^{1} 、$ 長谷川 豊 ${ }^{1} 、$

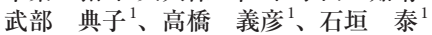

${ }^{1}$ 岩手医科大学附属病院 糖尿病・代謝 - 内分泌内科、 ${ }^{2}$ 岩手県立宮古病院 内 科

【目的】一般的に糖尿病性腎症は緩徐に進行するが、その中に腎症が急速に悪 化する症例が抢り Rapid decliner（RD）と呼ばれる。RDの背景因子や様々 なパラメー夕の経過の違いを明らかにする。【方法】当科外来通院中の糖尿 病性䁂症 1 期から 3 期の 2 型糖尿病患者の中から、年間の $\mathrm{eGFR}$ 低下が $5(\mathrm{ml}$ $\mathrm{min} / 1.73 \mathrm{~m} 2$ ) 以上であった症例を RD群と定義した。観察開始時点での性、年 齢、血清Creをマッチさせた症例を対照群とし、最大 3 年にわたり、背景因子 や様々なパラメー夕を後ろ向きに比較検討した。【結果】 RDは61名で、男性 37 名 $(61 \%)$ 、観察開始時の平均年齢は 59.5 歳、Cre0.82、eGFR74.6。これら の背景をマッチさせた対昭群を同数抽出した。観察開始時の糖尿病羅病期間、 BMI、唚煙率、降圧剤内服者の割合、LDL-C、HDL-Cは同程度であった。し かし HbAlc(9.0vs7.1\%, $\mathrm{p}<0.01)$ 、収縮期血圧 (142vs132 mmHg, $\mathrm{p}<0.05)$ 、拡張期 血圧 $(81 v s 75 \mathrm{mmHg}, \mathrm{p}<0.05)$ 、中性脂肪 $(219 \mathrm{vs} 158 \mathrm{mg} / \mathrm{dL}, \mathrm{p}<0.05)$ ) 尿アルフ ミン量 $(1250 \mathrm{vs} 98 \mathrm{mg} / \mathrm{g} \cdot \mathrm{cre}, \mathrm{p}<0.01)$ は対照群に比較してRD群で有意に高值 であった。 3 年間の平均 $\mathrm{eGFR}$ 変化はRD群で-9.1/年に対して、対照群でー 1.9/年であった観察開始時に有意に高值であった HbAlc、血压、中性脂肪、 尿アルブミン量は、 3 年の観察期間中に両群の值が次第に近づくものの RD 群 で持続して高值であった。【考察】 RD群の特徽としては、対照群と比較して 観察開始前までに血糖や血圧、脂質管理が不良であり、な扔から、観察期間中 も血糖や血圧の管理が不十分なことであった。すなわち平均罹病期間 14 年に 扔けるコントロール状態が不良であることが、後の糖尿病性腎症重症化の大き な要因であると考えられた。

\section{3-5-2 母体男性化副腎腫瘍による 46,XX性分化疾患にお ける11-oxy-androgensの検討}

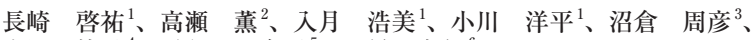
本間 桂子、長谷川 奉延、 ${ }^{5}$ 樑見 真紀 ${ }^{6}$

${ }^{1}$ 新潟大学医歯学総合病院 小览科、 ${ }^{2}$ 山形大学医学部 神経内科, 糖尿病・代 謝・内分泌内科, 血液内科、 ${ }^{3}$ 山形大学医学部 小览科、 ${ }^{4}$ 慶應義塾大学病院 臨床検查科、笖㷳義塾大学医学部 小児科、 ${ }^{6}$ 国立成育医療研究センター 分 子内分泌研究部

【背景】胎児外性器男性化は、古典的アンドロゲン産生経路と非古典的アン ドロゲン産生経路（Backdoor経路）で産生されるジヒドロテストステロン (DHT) の暴露により生じる。近年新たな副㹂アンドロゲンである11-oxyandorogens (110xC19) が注目されて抢り、21水酸化醉素欠損症女児の外性 器男性化において11-KTや11-KDHT の関与が報告されている。本研究の目 的は、母体男性化副腎腫瘍により児が46.XX DSDをきたした母体のアント ロゲン（血清110xC19含む）を測定し、胎児外性器男性化への関与を検討す ること【対象と方法】出生時上り Prader分頪 3 度の外性器男性化を認めた

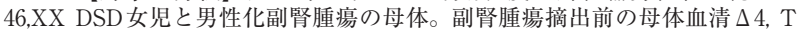
DHTおよび血清11oxC19 (LC/MS/MS法) おょび尿中ステロイドプロファイ ル $(\mathrm{GC} / \mathrm{MS}$ 法) を測定した。【結果】尿中ステロイドプロファイルでは、尿 中 DHEA 代謝物は正常上限值7倍と著明高値であったが、 $\Delta 4$ 代謝物は正常上 限値1.7倍であった。またBackdoor 経路の允進はみられなかった。一方、尿 中 $110 H \Delta 4$ 代謝物は、正常上限值 4 倍と高值であり、血清 $11 \mathrm{KT}$ は正常上限値 4 倍と高值であった。母体TやDHT は正常範囲であった。考察・結語】尿中 $11 \mathrm{OH} \Delta 4$ 代謝物や血清11KTが異常高值を示したことから、外性器男性化に胎 盤で不活化されない11KTや11KDHTが関与したと推測した。母体男性化副 㹂腫瘍による胎児の外性器男性化において、11oxC19が主要なアンドロゲンで あることが示唆された。

\section{3-5-4 栄養膜細胞の機能分化における 介因子EPAC2の役割}

吉江 幹浩 ${ }^{1}$ 、岡田 美紗希 ${ }^{1} 、$ 石川 源 ${ }^{2}$ 大丸丸 貴子 ${ }^{3} 、$ 竹下 俊行 ${ }^{2}$ 、 加藤 聖子 3 井坂 惠一 ${ }^{4}$ 、西 洋孝、田村 和広

${ }^{1}$ 東京薬科大学 薬学部 薬理学教室、 ${ }^{2}$ 日本医科大学 医学部 産婦人科学教室 ${ }^{3}$ 九州大学医学部婦人科学産科学教室、 4 東京医科大学 医学部 产科婦人科 学教室

【目的】胎盤䋐毛を構成する細胞性栄養膜細胞は、多核の合胞体栄養膜細胞一 と分化・融合し、妊娠維持に必要な䋐毛性ゴナドトロピン（HCG）やプロゲ ステロン (P4)を分泌する。この分化過程の異常は胎盤形成障害をもたらし、 妊娠高血圧症候群 (HDP) や胎児発育不全 (FGR) 発症の原因となる。本研 究では、栄養膜細胞の分化における ついて検討した

【方法】奸娠末期胎盤から栄養膜細胞を単離し、Rap1の活性化と機能的分化に 対する EPAC2 阻害薬（ESI-05）の効果を調べたささらに、FGRやHDPにお ける EPAC2の関与を解析するため、患者胎盤組織を用いた EPAC2 下流シグ ナル伝達因子Rap1の発現解析を行った。

【結果】初代培養栄盖膜練胞に执いて ESI-05は、cAMPアナログ刺激による Rap1 の活性化を抑制した。ESI-05 は、cAMPアナログ処置により誘導される HCG 産生を抑制した。また ESI-05 は、AMPアナログによるコレステロー 儿側鎖切断䤇素（P450scc）の発現光進を抑制し、P4産生を低下させた。ESI05は、細胞融合促進因子でSyncytin2の発現を抑制するとともに、紐胞融合抑 制因子であるSuppressynの発現を増加させた。さらに、HDPやFGRを併発 した早産患者の胎盤䄉毛組織ではRap1の発現量が低かった。

【考察】EPAC2/Raplを介したcAMPシグナルは、胎般形成過程において栄盖 膜細胞の機能的分化に関与し、このシグナル系の異常がHDPやFGR と連関す ることが示唆された。 


\section{3-5-5 ヒト子宮内膜脱落膜細胞におけるEPAC-C/EBP $\beta$ を介したプロラクチン発現機構}

草間 和哉、吉江 幹浩、田村 和広

東京薬科大学 薬学部 薬理学教室

【背景】胞胚の着床により開始される娃娠の成立においては子宮内膜の脱落膜 化による胞胚受容能の獲得が不可欠である。ヒト子宮内膜間質細胞（ESCs） は、主に卵巣ステロイドの作用により cAMP/PKAシグナルを介して脱落膜細 胞へと分化する。それに伴い、ESCsは敷石状の形態へと変化し、脱落膜プロ ラクチン (dPRL) を産生・分泌する。以前、PKAとは異なる cAMP/EPAC シグナルがPKA と協調して脱落膜化を促進することを報告した。一方、脱落 膜化時の $\mathrm{dPRL}$ 発現上昇には、転写因子である C/EBP $\beta$ と FOXO1が関与す る。本研究では、 $\mathrm{dPRL}$ 発現における EPAC シグナルと C/EBP $\beta$ 、FOXO1の 役割について検討を行った。

【方法】初代培養ESCsにおいて、PKAおよびEPAC選択的活性化薬による FOXO1とC/EBP $\beta$ 発現および、それらの発現に対するEPAC siRNAの効果 について調べた。また、C/EBP $\beta$ の転写活性に対するEPACの作用について dPRLの転写調節領域を用いたレポーターアッセイによる検証を行った。

【結果】C/EBP $\beta$ と FOXO1の発現量はPKA活性化薬で増加したが、EPAC 活性化薬では変化しなかった。しかしながら、EPACノックダウンによりC/ $\operatorname{EBP} \beta$ 発現は減少した。レポーターアッセイにおいて、PKAおよびEPAC活 性化薬はdPRL転写活性レベルを上昇させたが、C/EBP $\beta$ の結合部位を変異さ せると、EPAC活性化薬による転写活性レベルの上昇が消失した。

【考察】ヒト子宮内膜間質細胞の脱落膜化において、EPACはC $/ \mathrm{EBP} \beta$ を介し てPKA と協調してdPRLの発現を制御していることが示唆された。

\section{3-5-7 WDR11遺伝子異常を認め可逆性であった成人発症 型男性特発性低ゴナドトロピン性性腺機能低下症 の一例}

山田 梨絵 ${ }^{1}$ 、山北 宜由 ${ }^{1}$ 、村山 正憲 ${ }^{1} 、$ 安田 圭吾 ${ }^{1}$ 萩原 徳康 ${ }^{2} 、$

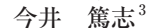

松波総合病院 内科、 ${ }^{2}$ 松波総合病院 泌尿器科、 ${ }^{3}$ 松波総合病院 産婦人科

【症例】33歳男性。思春期までの性発達に特に問題なし。X-11年第一子あり X-9年、X-8年妻娃娠したが流産。X-7年に女性化乳房、ひげや体毛の軟化、 性欲低下、勃起不全等の自覚あり他院受診L低LH・FSH、低テストステロシ 血症を指摘され当院紹介。精液検查では自然好娠不可の状態であった。嗅覚 低下の自覚なL。LH-RH負荷試験ではLH低反応・遅延性反応、FSH無〜低 反応、 $\mathrm{LH}-\mathrm{RH}$ 連続負荷試験では反応の回復あり。成人発症型の特発性低ゴナ ドトロピン性性腺機能低下症 $(\mathrm{IHH})$ と診断。GnRH間歇皮下注による治療を 開始。その後自然娃娠で $X-6$ 年と $X-4$ 年に 2 児を得た。 $X-3$ 年アリナミンテ ストで替伏時間の軽度延長を認めた。 X-1 年 $\mathrm{GnRH}$ 問歇皮下注中止。中止 5 加 月後の LH-RH負荷試験ではLH,FSHの基礎值・反応ともに正常範囲、テスト ステロンも正常範囲であり性腺機能の回復が維持されていた。遺伝子検查で WDR11のヘテロ接合性ミスセンスバリアント（c.2390G>A; p.Arg797His）を 認めた。考察】IHHにおいて各種の遺伝子異常が報告されているが、成人発 症型での遺伝子異常の報告は少ない。以前はIHHの病態は生涯持続すると考 えられていたが近年は10-15\%の症例で可逆性が認められたと報告されてい る。可逆性IHHに扔ける遺伝子異常に打いてWDR11は検索した範囲内では今 まで報告されていない。一旦回復した性腺機能が再度低下する例の報告もあ り、長期経過を追跡する必要がある。

\section{3-5-9 加齢に伴う皮膚ステロイド産生系の亢進は毛包幹 細胞のタンパフ質品質管理を障害する}

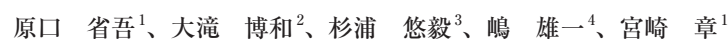
${ }^{1}$ 昭和大学 医学部生化学講座、 ${ }^{2}$ 昭和大学 医学部 解剖学講座、 ${ }^{3}$ 慶應義塾大 学医学部 医化学教室、 ${ }^{4}$ 川崎医科大学 医学部 解剖学教室

皮膚のステロイド産生系は、副腎や性腺由来のステロイドと協働して皮虐の恒 常性制維持や機能発現制御を担っている。しかし、加齢に伴う性腺ステロイド の低下が、皮䖉ステロイド産生系にどの様な変化を引き起こすのか不明であっ た。そこで我々は高齢マウスを用いて解析を行い、加齢に伴う性腺ステロイド

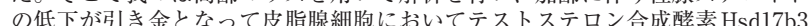
の発現增加が起こり、その結果、皮虐に病的高濃度のテストステロンが蓄積す ることを明らかにした。そこで本研究は、高糐時の皮虚に高濃度に蓄積した テストステロンが皮㢓機能にどの様な影響を与えるのかを明らかにすることを 目的とした。高齢マウス皮虚へ1か月間Hsd17b3 阻害郕を塗布したところ、マ ウス背部の毛の伸長が起こった。従って、高濃度テストステロンに毛の伸長抑 制作用があると考号れたことから、毛包領域でアンドロゲン受容体ARの免 疫組織化学染色を行ったが発現が見られなかった。そこで、アンドロゲン作用 に介在することが報告されている重鉛トランスポーターZIP9について解析を 行ったところ、毛包幹細胞をはじめとする毛包領域の細胞に発現が見られた。 そこで、高齢マウスより単離した毛包幹細胞と A-431ヒ卜類表皮癌細胞を用 いて、テストステロンの作用をゴルジ体に発現するZIP9に着目して解析した ところ、高濃度テストステロンはZIP9を介して細胞内の梩鉛イオン恒常性を 障害し、タンパク質品質管理に関わるシャペロン分子ERp44の働きを阻害す ることが分かった。

\section{3-5-6 日本人女性の月経周期・基礎体温の年蹗依存的変 化之季節性変化 : 「ルナルナ」の600万周期の解析}

鳴海 覚志 ${ }^{1} 、$ 辰巳 嵩征 ${ }^{2} 、$ 三瓶 舞紀子 ${ }^{3}$ 、齊藤 和毅 ${ }^{2} 、$ 本田 由佳 ${ }^{4} 、$ 岡崎 有香 ${ }^{4}$ 、荒田 尚子 $4^{4}$ 鳴海 加奈子 ${ }^{5}$ 、森崎 菜穂 ${ }^{3}$ 、石川 智則 ${ }^{2}$ 、 中村 茜里 ${ }^{6}$ 、塚原 信 ${ }^{6}$ 、佐藤 誠 $6^{6}$ 、小林 ${\text { 礼 }{ }^{6} 、 \text { 日根 麻綾 }}^{6}$

${ }^{1}$ 国立成育医療研究センター 分子内分泌研究部、 2 東京医科歯科大学大学院 荻城県小览周産期地域医療学講座、 ${ }^{3}$ 国立成育医療研究セン夕ー 社会医学研 究部、 ${ }^{4}$ 国立成育医療研究センター 母性内科、 ${ }^{5}$ 東京都済生会中央病院 産婦 人科、 ${ }^{6}$ 株式会社エムティーアイ

【背景】月経周期は 40 代中頃から延長するが、年齢依存的変化の詳細は大部分 不明である。基礎体温（BBT）の年齢依存的変化や季節性変化の詳細は知ら れていない。

【方法】2016〜2017年に「ルナルナ」で記録された匿名データのうち 15 歳以 上55歳未満のユーザー 322,436 人に由来する $5,956,886$ 周期を解析した。月経周 期の平均值は外れ值を除外し Box-Cox変換のうえ求めた。季節性変化は月別 集計をもとに評価した。

【結果】(年齢依存的変化) 月経周期は 10 代後半から増加し 23 歳で極大 (平均 30.7 日) となった。以後減少に転じ 45 歳で極小（平均 27.3 日）をとった後に増 加した。卵胞期BBT は年齢によらず一定であった。対照的に黄体期BBT は 10 代後半から増加して 30 歳〜 40 歳にプラトーを形成し、42歳以降に減少に転じ た。(季節性変化) 月経周期は季節性変化を示さなかった。卵胞期BBT、黄体 期 BBT とも夏に高く冬に低い季節性変化を認めたが、その変動幅は $0.1{ }^{\circ} \mathrm{C}$ 未満 であった。

であった。 日間短縮した。黄体期の変動幅の小ささを考慮すると、卵胞の状態を反映した 変化と推測される。一方、黄体の状態を反映する $\mathrm{BBT}$ 上昇は 30 歳から 40 歳に かけ一定であった。本研究は卵胞と黄体では年齢依存的変化が顕在化する時期 が異なることを示した。

\section{3-5-8 非閉塞性無精子症における精巣内アロマターゼの 発現}

白石 晃司、田原 正則、松山 豪泰 山口大学 医学部 医学系研究科 泌尿器科学講座

【背景】精子形成は精巣内テストステロン（T）とエストラジオール（E2）濃 度に依存しており、アロマターゼ（cytochorme P450 aromatase, CYP19A1) による制御を受ける。我々はヒト精巣組織を用いたトランスクリプトーム解 析よりアロマターゼは非閉塞性無精子症 (NOA) で発現が光進していること を見出しているが、その局在や精子形成との関連につては不明である。【対象 と方法】精子形成正常18名 (コントロール群) およびNOA72名のパラフィン 切片を用いた抗 cytochorme P450 aromatase抗体を用いた免疫染色による精 巣内アロマターゼの発現を検討し、臨床パラメーター（LH, FSH, T, E2、精巣 生検所見拄よび顕微鏡下精巣内精子採取術での精子採取率) との比較を行っ た。【結果】ヒト精巣内に㧧体アロマターゼは主にライディッヒ細胞に局在 しており、NOA症例に打ける染色性は-/+:6例、 $++: 38$ 例、 $+++($ 強陽性の 細胞がクラスターを形成）：28例に分類可能であった。コントロール群におい てはー/+が16例 $(89 \%)$ であるのに対し、NOA群では++以上の症例が 66 例 （92\%）を占め、maturation arrestから Sertoli cell onlyへ造精機能障害が悪化 するにつれその発現が立進した。アロマターゼの発現充進と T/ E2 および精子 採取率の低下を認めた。【考察】ライデイッヒ細胞におけるアロマターゼ発現 穴進と造精機能障害との間に強い関連を認めた。内分泌学的所見に基づいた精 巣内アロマターゼの発現が予湘可能であり、アロマターゼ阻害剤の造精機能障 害に対する適応について検討予定である。

\section{3-6-1＼cjkstart本邦における内因性高インスリン性低血糖症の実 態調査}

山田 勇気 ${ }^{1}$ 、北山 称、樋口 真司 ${ }^{1} 、 川$ 北理恵 ${ }^{1}$ 、金森 豊 ${ }^{2} 、$ 高橋 満保 $^{3}$

${ }^{1}$ 大阪市立総合医療センター 小児代謝 ・ 内分泌内科、 ${ }^{2}$ 国立成育医療研究七 ンター臓器・運動器病態外科部 小児外科、 ${ }^{3}$ 膵島細胞症患者の会

【背景】内因性高インスリン性低血糖症は、希少疾患であるため、一部の疾患 を除いて䛦療指針に忌しく、治療や予後の実態調査も十分に行われていない。 【目的】小児、成人の内因性高インスリン性低血糖症の患者数、治療、合併症、 QOLの実態を調查する。

【方法と結果】本邦の 300 床以上の病院の 1,717 診療科 (内科939、小児科 778) に調查票を送付し、過去 2 年間に診療が行われた 785 人の患者を同定した。内 訳は、先天性高インスリン性低血糖症 (CHI) 447、インスリノーマ205、イン スリン自己免疫症候群 (平田病) 22、非インスリノーマ低血糖症候群 (NIPHS) 111 ( 上部消化管術後低血糖 33 、食後反応性低血糖 57 、後天性膵島紐胞症 10 、

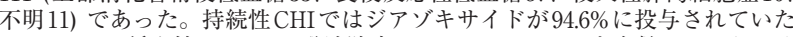
が、35.7\%に低血糖、28.1\%に発達障害、14.3\%にてんかんを合併していた。イ ンスリノーマは $77.6 \%$ に膵切除が施行されていたが、手術非施行群では $44.7 \%$ に低血糖を認めた。平田病、NIPHSでは食事療法、 $a$-グルコシダーゼ阻害薬 の投与例が多かったが、高頻度に低血糖が残存していた。

【考察】多くの疾患群で、過去の全国疫学調查よりも多数の患者を捕捉した。 持続性CHI、インスリノーマの手術非施行群、NIPHSでは特に神経学的後遺 症の頻度が高く、繰り返し低血糖をきたすす事が要因と推測される。近年は適切 な治療による合併症の軽減も見受けられ、疾患群ごとの治療指針の策定、患者 支援体制の構築を進めていく必要がある。

【結語】小児から成人にわたる内因性高インスリン性低血糖症の全国疫学調查 を初めて行い、治療や予後の実態を明らかにした。 


\section{3-6-2ジアゾキシドが有効であった木モ接合性 ABCC8 遺伝子新規变異による先天性高インスリン血症の} 1 例

宮川 雄一 ${ }^{1.2}$ 、高澤 啓、我有 莱希 ${ }^{1}$ 、鹿島田 健一 ${ }^{1}$ ${ }^{1}$ 東京医科歯科大学 発生発達病態学分野、 ${ }^{2}$ 川口市立医療センター 小児科

【背景】 $A B C C 8$ 遺伝子の両アレル機能整失による先天性高インスリン血症 (CHI) は一般に重症かつ難治で、第一選択薬であるジアゾキシド（DZX）に 不応とされ、低ケトン性低血糖を繰り返し神経学的予後が悪い症例、膵切除 などの侵襲的治療を要する症例が多数報告されている。一方、DZXに反応し た報告例は数例のみである。【目的】 DZXに反応し、良好な経過を得られた木 モ接合性 $A B C C 8$ 遺伝子新規変異による $\mathrm{CHI}$ を経験したので、報告する。【家 族歴】両親：クルド人、はとこ婚。【症例】1歳女児。在胎 39 週 2 日、4075 g $(+3.4 \mathrm{SD}) 、 52.8 \mathrm{~cm}(+2.2 \mathrm{SD})$ と胎内過成長を呈した。生後早期に低血糖を 認め、頻回哺乳で対応された。生後13 个月時に痓攣を発症、BS: $35 \mathrm{mg} / \mathrm{dl}$ 総ケトン体: $37 \mu \mathrm{mol} / \mathrm{l}$ 、 IRI: $1.22 \mu \mathrm{IU} / \mathrm{ml}$ と高インスリン・低ケトン性の低 血糖を認めた。グルカゴン $0.03 \mathrm{mg} / \mathrm{kg}$ 静注で血糖値が著明に上昇し、臨床経 過も鑑及 $\mathrm{CHI}$ と診断したDZX $7 \mathrm{mg} / \mathrm{kg} / \mathrm{day}$ 内服で食後 2 時間の血糖值が改 善し [治療前：48（41 61） mg/dl、治療後：69（58 76） $\mathrm{mg} / \mathrm{dl} 、 \mathrm{p}=0.02$ ]、有 効と考えられた。ABCC8遺伝子に両親由来のホモ接合性の新规変異 (c.4202$1 \mathrm{del} G$ ) を同定した。発達は軽度の発語の遅れを認めるの及で比較的良好であ る。【考察】本症例が軽症な理由として、1.変異部位がC末端側にあり、比較 的蛋白の機能が保たれたこと。2 $A B C C 8$ 遺伝子は複数のスプライスバリアント が報告されていることから、選択的スプライシングの影響。 $3 . A B C C 8$ 遺伝子 変異では同じ変異を持つ家系内での表現型に差があることから、エピジェネ テイックな修飾の影響、が考えられる。【結語】 $A B C C 8$ 遺伝子の両アレル変異 によるCHIでも、DZXが有効な場合がある。

\section{3-6-4 日本人MODy1-3におけるMODY calculator 有 用性の検討}

樋口 真司、北山 称、大矢知 真希、山田 勇気、川北 理恵、 依藤 亨

大阪市立総合医療センター 小児代謝・内分泌内科

【背景】糖尿病の成因を適切に診断することは、病態に適した治療法の選択 と予後の改善につながる。若年発症糖尿病（MODY）は単一遺伝性糖尿病で ある。英国白人MODYを対象とした遺伝子診断前予測ツールであるMODY calculator (https://www.diabetesgenes.org/mody-probability-calculator)(診断 時と現在年齢、性別、インスリン加療歴と使用開始時期、BMI、HbAlc、両 摬罪患歴)が作成されているが、日本人での有用性を検討した報告は少ない。 【目的】日本人 MODY 患者に扔ける MODY calculatorの有用性を検討する。 【対象・方法】 日本人 18 歳未満で臨床的にMODYが疑われ、当院で HNF4A MODY, GCK-MODY, HNF1A-MODY の遺伝子解析された症例。calculator 陽 性的中率(PPV)75\% 以上を $\mathrm{P}$ 陽性群、75\%以下を $\mathrm{P}$ 除性群とし、validation test を施行した【結果】遺伝子診断陽性者、P 陽性群は各々以下の通りであった。 HNF4A-MODY：3例、3例、GCK-MODY；38例、38例、HNF1A-MODY 13例、11例、遺伝子診断陰性者は10例であった。 calculatorの感度 $96 \%$ 、特異 度 70\%、PPV95\%であった。HNF1A-MODYのP P 陰性群 2例は共にインスリン 6 ケ月以内使用例であり、仮にインスリン未使用、診断後 6 ケ月以降使用を選 択すると各々 PPVが $6.4 \rightarrow 75.5 \% 、 49.4 \rightarrow 75.5 \%$ 以上となった。【考察】GCKMODYに抢ける calculatorの有用性は極めて高い。一方、HNF4A-MODY HNF1A-MODYでも有用であるが、HNF4A-MODYでは対象数を増やす必 要があり、HNF1A-MODYでは6ケ月以内インスリン使用例でPPVが極端に 低く見積もられる可能性がある。【結論】日本人小児MODY患者でもMODY calculator は有用である。ただし、診断後6 个月以内インスリン使用群では PPVが極端に低く見積もられる可能性があり注意が必要である。

\section{3-6-6 健常者における糖代謝の概日リズムとそのメカニ ズムの検討}

藤本 留理子 ${ }^{1} 、 太$ 田 康晴 ${ }^{1}$ 、松村 卓郎 ${ }^{1} 、$ 田口 昭彦 ${ }^{1} 、$ 山本 薰 ${ }^{1}$ 、 廣重 俊典 ${ }^{1}$ 、秋山 優、竹田 孔明 ${ }^{1}$ 、明石 真 $^{2}$ 、谷澤 幸生 $^{1}$ '山口大学大学院医学系研究科病態制御内科学講座、 ${ }^{2}$ 山口大学時間学研究所

【背景】概日リズムの破綻が糖尿病発症を促すが、そのメカニズムの解明を目 指し、健常男性における朝晚での糖代謝の相違と時計遺伝子発現量との関連 を検討した。【方法】健康男性成人に対し、高インスリン正常血糖グルコース クランプ試験 99 名)または75oOGTT(14名)を、各被験者に対し 8 時と 20 時に 行ったまた毛根の時計遺伝子発現量をりアルタイム PCR法で解析した。結 果】クランプ試験での糖注入率は 8 時で高值 $(\mathrm{p}=0.001)$ であり、筋肉でのインス リン感受性は朝の方が高いことがわかった。OGTTでのAUC Glucoseは8時 vs 20 時: 277 vs $333(\mathrm{mg} \mathrm{hr} / \mathrm{dl})$ であり、20時で高值であった $(\mathrm{p}<0.001)$ 。血中イ ンスリンの頂优の時間は8時 vs 20 時: 55.7 vs 83.6 (分)で ( $\mathrm{p}=0.01)$ 、 0 の 30 分 までの AUC Insulin は8時 vs 20 時: $36.0 \mathrm{vs} 24.8(\mathrm{mIU} \mathrm{hr} / \mathrm{dl})$ であった $(\mathrm{p}=0.02)$ これらの結果から、インスリン初期分泌は20時の方が低いことがわかった。 一方、0 30 分におけるAUC Gluclose と AUC Insulin の積で示される Hepatic Insulin Resistance Index は 8 時 vs 20 時: 855 vs $527(\mathrm{p}=0.03)$ であり、肝インス リン抵抗性は8時の方が大きいことがわかった。毛根の時計遺伝子Per2の発 現量と 0 0 60分の AUC Insulin 及びHepatic Insulin Resistance Indexの朝晚の 変化量との間に有意な相関が認められた。結論】健常人では朝に比べ晚で耐 糖能が低下し、その差は筋肉のインスリン感受性とインスリン初期分泌で規定 され、肝糖新生はむしろ晚の方が低下している可能性がある。各組織に扔ける 糖代謝の概日リズムは極めてダイナミックで、特に膵肝においては時計遺伝子 がこのリズム形成に関与していることが示唆された。

\section{3-6-3 当院におけるインスリノーマ手術症例の檢討}

藤田 佑紀 ${ }^{1}$ 、浜本 芳之 ${ }^{1,2}$ 、原口 卓也 ${ }^{1}$ 、山口 裕子 ${ }^{1}$ 、窪田 創大 $^{1}$ 和泉 清拓、岡本 紗希、桑田 仁司 ${ }^{1}$ 、表 孝德 ${ }^{1}$ 、田中 永昭 ${ }^{1} 、$ 河本 泉 ${ }^{2} 、 今$ 村 正之光、清野 裕

1関西電力病院 糖尿病・代謝・内分泌センター、関西電力病院 神経内分泌 腫腸センター

【目的】インスリノーマは内分泌症状はあるものの腫瘍が小さいために局在診 断に苦慮することが多いが、診断率の向上により、症状の出現から比較的早期 にインスリノーマと診断される例が増えている。今回当院におけるインスリ ノーマ手術症例について検討したので報告する。【方法】2011年10月-2019年 8 月まで当院で手術を行い術後当院でフォローされている18症例【結果】女性 14 例、男性 4 例、手術時の平均年齢は 50.3 歳、初発症状は意識消失発作や意諳 混濁、傾眠が 11 例、四肢しびれや脱力、呂律困難等が 4 例、異常行動・冷汗 · 易疲労感が各 1 例で、症状出現から診断までの期間は平均 22 ヶ 月であった。 Fajans指数の陽性率は $17 \%$ 、Grunt 指数 $6 \%$ 、Turner 指数 $50 \%$ 、Taminato 指 数 $50 \%$ であったが、Grunt指数の cut off 值を 11 とすると陽性率は $94 \%$ となっ た。CTやMRIでは腫瘍同定が困難な例もSASIテストやEUSにて局在診断が 可能で、部位は膵頭部 9 例、膵体部 3 例、体尾部 2 例、尾部 4 例であった。術式 は、腫瘍核出術 12 例、膵体部切除 1 例、膵体尾側切除 2 例、膵尾部切除 1 例、 膵頭十二指腸切除 2 例、腫瘍の最大径は平均 $13.2 \mathrm{~mm}$ で、NETG1:13例、G2: 例で、2例はNesidioblastosisの所見だった。全例に転移所見は認めず、術後内 分泌症状の改善を認めた。Nesidioblastosisの 2 例のみ数年後に低血糖症状が再 燃した。術後糖尿病発症は3例であった。【まとめ】インスリノーマの同定や 局在診断にはSASIテストやEUSが有用であったが、nesidioblastosisは術後再 燃していたほか、術後糖尿病を発症した例も見られた。術後も継続的な機能評 価が重要と考えられた

\section{3-6-5 インスリン受容体遺伝子に变異を有さない遺伝的 インスリン抵抗症の解析}

竹内 健人、廣田 勇士、浜口 哲矢、小川 涉 神戸大学大学院 医学研究科 糖尿病・内分泌内科学

【背景・目的】A型インスリン抵抗症（以下 A 型）はインスリン受容体遺伝子 (INSR) 異常に上る症候群であり早世を伴う重症刑はRabson-Mendenhal たはDonohue症候群（以下 $\mathrm{R}-\mathrm{M} / \mathrm{D}$ 症候群）と呼ばれる。これらに類似した臨 床像を示すがINSR 異常のない例が存在し、受容体後障害が原因と推測される が、大半の例で原因遺伝子は明らかではない。我々は受容体後障害が疑われる インスリン抵抗症で、PI3キナーゼ $885 a$ 遺伝子(PIK3R1)変異を有する例を本 邦で初めて見出した。本研究では「A型や R-M/D症候群が疑われるがINSRに 異常のない例」の遺伝学的検討を行う。【方法】厚労省ホルモン受容機構異常 に関する研究班で収集された、あるいは、自施設で独自収集したA型や R-M/ $\mathrm{D}$ 症候群疑い例にINSR と PIK3R1 のシークエンスを、原因不明例にエクソーム 解析を実施した。【結果と考察】A型またはR-M/D 症候群疑い 14 例中 6 例に INSR変異を、4例にPIK3R1 変異を認めた。原因遺伝子不明4例のエクソーム解 析では、IRS1、IRS2、PI3キナーゼ触媒サブユニット (p110a)、Akt1、Akt2 PDK1、PTENなど、インスリン情報伝達に関わる主要遺伝子に変異を認めな かった。PIK3R1変異はSHORT 症候群の原因であることが最近明らかとなった が、4例のPIK3R1 変異例は、黑色表皮腫、多毛、脂肪減少などインスリン抵抗 症の特徵に加え、SHORT 症候群の特徵である小顎、後頭部突出、眼球陥凹を 乵めるも、やはり SHORT症候群に伴うとされる関節過伸展やRieger奇形はな かった。結論】PIK3R1異常は遺伝的インスリン抵抗症の中でINSR 異常に次 いで頻度が高いと考えられた。SHORT症候群は約半数に糖尿病を伴うとされ るがインスリン抵抗症として加療される患者の中にPIK3R1 異常が存在するこ とに留意すべきである

\section{3-8-1＼cjkstart症候性ラトケ震胞と慢性炎症}

立花 修 ${ }^{1}$ 、中川 淳 $^{2}$ 、笹川 泰生 ${ }^{3}$ 、古家 大祐 ${ }^{2}$ 、飯塚 秀明 ${ }^{1}$ 金沢医科大学 脳神経外科、 ${ }^{2}$ 金沢医科大学 糖尿病- 内分泌内科、 ${ }^{3}$ 金沢大学 脳神経外科

【はじめに】症候性ラトケ囊胞（RCC）は、霊胞の増大や周囲への圧迫だけで は説明できない症状として、激しい頭痛と下垂体機能低下症があり、慢性炎症 との関係が注目されてきた。症候性RCCにおける下垂体慢性炎症の発生機序 を明らかにすべく、囊胞内炎症性サイトカインの動態と受容体を含めた発現拧 よび分布を検討した。【対象と方法】手術施行した症候性RCC 30 例を対象と した。4例の囊胞内容液の Protein profiling を捛こない、同定した炎症性サイ トカイン（IL-1beta, IL-6, IL-12 and TNF alpha）の測定をおこなった。また、 免疫組織化学的染色にてIL-1b、IL-6、IL-12 拈上びTNF-a、およびその受容 体（IL6R、TNFR-1、TNFR-2）に対する抗体を用いて検討した。【結果】豊 胞液のサイトカイン濃度は、IL-6 $(10537 \mathrm{pg} / \mathrm{ml})$ が最も高く全症例で同定され たが、汎下垂体前葉機能不全をきたした症例で有意に高い傾向を示した。IL1b、TNF-aはそれぞれ $74 \% 、 57 \%$ に同定され、 $166 \mathrm{pg} / \mathrm{ml} 、 61 \mathrm{pg} / \mathrm{ml} ゙$ あっ た。病理学的に慢性炎症を伴う症例では、IL-6やTNF-aの発現が囊胞上皮に みられた。下垂体前葉には炎症細胞浸潤がみられ、IL-1b、IL-6、TNF-a 発現し、同時に炎症細胞や腺細胞にはIL-6RやTNF-Rの発現も認めた。剖検 下垂体では、ラトケ襄遺残上皮にIL12 掞よびIL-6R、TNF-Rの発現が見られ た。【結語】症候性RCCの発生と炎症の機序は、ラトケ襄遺残上皮の TNF-R signaling 抢よびIL-6 signaling pathwayを介して転写活性や IL-6 遺伝子の増 幅が抢こなわれ、炎症性サイトカインを産生分泌し、囊胞液が下垂体に暴露す ることで炎症細胞が浸潤し、この炎症細胞がさらに炎症性サイトカインを産生 することで炎症輪が形成され、遷延化するものと推測された。 


\section{3-8-2 下垂体腺腫内出血による症状の発現に関与する腺 腫と周囲構造の檢討}

林 康彦 ${ }^{1,2}$ 、大石 正博 ${ }^{2}$ 、笹川 泰生 ${ }^{2}$ 、福井 一生 ${ }^{2}$ 、立花 修 $^{1}$ 、 中田 光俊 ${ }^{2}$ 、飯塚 秀明

${ }^{1}$ 金沢医科大学脳神経外科、 ${ }^{2}$ 金沢大学脳神経外科

【背景】下垂体腺腫は内部の血流が豊富で、高頻度に腫瘍内出血を生じる。そ の症状の程度は無症候性から突然の激痛や視力視野障害まで样々であり、潜在 性に下垂体機能低下も合併しやすいことはよく経験するが、現在に至るまで 症状発現に寄与する因子は明らかでない。我々は下垂体腺腫内出血の症状発 現における腺腫と周囲構造の関与する因子に関して検討した。【方法】200616 年に施行された内視鏡的下垂体腺腫摘出術中、最大径 $15 \mathrm{~mm}$ 以上の下垂体 腺腫235例中腫㾦内出血を認めた82例を対象とした $3 T$ MRIにて下垂体腫瘍 と周囲構造、thin slice CTAにて蝶形洞内骨化を評価した。【結果】平均年齢 は52.0才（15 88)、男女比は34:48。非機能性腺腫が 67 例、プロラクチン産生 性腺腫が 15 例。A 群 (無症状もしくは症状が軽微、33例)、B群 (症状が徐々 に発症、31例)、C群（症状が重度で急性に発症、18例）に分類した。腫瘍最 大径は A 群 $29.5 \mathrm{~mm} 、 2$ 群 $31.3 \mathrm{~mm} 、 3$ 群 $21.6 \mathrm{~mm}$ でC 群が有意に小さかった。血 腫の腫瘍内での体積率は A 群 $38.5 \%$ 、 B 群 $53.8 \%$ 、C 群 $91.2 \%$ でC 群が有意に高 かった。トルコ鞍外進展の頻度は、C群で鞍上部進展が $38.9 \%$ 、Knosp grade 4 の海綿静脈洞内進展が $0 \%$ 、蝶形洞内進展が $0 \%$ と有意に少なかった。腫瘍 の compliance制御因子として、鞍隔膜の欠損部の最大径はA 群 $16.5 \mathrm{~mm} 、 \mathrm{~B}$ 群 $17.4 \mathrm{~mm} 、$ C 群 $8.9 \mathrm{~mm}$ とC群が有意に狭かった。蝶形洞内骨化（pre-sellar typeおよびconchal typeは3群間で有意差は認めなかった。結語】下垂体腺 腫内出血は無症候性から激しい卒中まで様々であるが、腫瘍内の血腫の比率 が大きいもの、蝶形洞内進展が無いもの、鞍隔膜欠損部が狭いもの、Knosp grade 3 までの側方進展などが有意に症状の程度に関与していた。

\section{3-8-4 非機能性下垂体腺腫の臨床病理学的因子とミス マッチ修復遺伝子MSH6/2 発現とPD-L1 発現との 関わり}

浦木 進丞 ${ }^{1}$ 、有安 宏之 ${ }^{1}$ 、土井麻子 ${ }^{1}$ 、中尾 直之 ${ }^{2}$ 、福原 紀章 ${ }^{3} 、$ 井下 尚子 ${ }^{4}$ 、西岡 宏 ${ }^{3}$ 、山田 正三 ${ }^{5}$ 、赤水 尚史 ${ }^{1}$ 和歌山県立医科大学 医学部 内科学第一講座、 ${ }^{2}$ 同 脳神経外科、 ${ }^{3}$ 虎の門病 院 間脳下垂体外科、 ${ }^{4}$ 東京都健康長寿医療センター 病理診断科、委山膎神 経センター病院 間脳下垂体センター

【背景・目的】 DNAミスマッチ修復 $(M M R)$ 遺伝子は種々の腫痬発生・増殖に 関与する。我々はこれまでに下垂体腺腫(PA)においてMMR遺伝子MSH6/2 遺伝子発現量の低下は直接的にPA増殖を促進することを報告した(Uraki S. EJ 2017 JCEM 2018)。一方、近年MMR蛋白欠損やはPD-L1高発現の悪性 腫瘍では免疫チェックポイント阻害薬の有効性が報告されているが、PAに 打ける直接的関連は不明である。本研究では、非機能性(NF)PAの臨床病理 学的因子と MSH $6 / 2 \cdot \mathrm{PD}-\mathrm{L} 1$ 連伝子発現の関連を明らかにする。【方法・結 果】NFPAにおいてMSH6/2・PD-L1 遺伝子発現量を Real Time PCR 法で定 量、相関解析ならびに臨床病理学的因子との関連を解析した。結果、1.knosp0 〜2群 $(\mathrm{n}=37)$ と $\mathrm{knosp} 3 \sim 4+$ 再発群 $(\mathrm{n}=52)$ に打ける各発現の比較で、後者にお いて有意な発現低下を認めた。2.MSH6/2発現量はPD-L1発現量と各々有意 な正相関を示した。3.Gonadotroph PA(GA,n=39)に比して silent corticotroph $\mathrm{PA}(\mathrm{SCA}, \mathrm{n}=27)$ 、null cell PA(NCA,n=11)では各発現の有意な低下を認めた が、PIT1系PA(Others,n=12)ではMSH6/2 発現は低下傾向であるが、PD-L1 発現は上昇傾向を認めた。PD-L1に関しては、IHCでも同様の傾向を認め た。また、 in vitroでMSH6 knockout AtT-20insでは、細胞増殖促進を伴っ てPD-L1発現が有意に低下した。【考察・結論】NFPAにおいて、GAに比し たSCA、NCA、Othersの MSH6/2・PD-L1発現の相違が、それらの臨床的に aggressiveな特徴に寄与している可能性が示唆された。

\section{3-8-6 下垂体、下垂体近傍病変術後低ナトリウム血症の 解析}

竹内 和人、永田 雄一、山本 太樹、水野 晃宏、若林 俊彦

名古屋大学大学院 脳神経外科

【目的】傍鞍部病変に対する内視鏡下経鼻経堞形骨手術（eTSS）後のDHN発 症について検討を行った。

【方法】2014年1月より2019年7月までに下垂体、下垂体近傍病変に対して eTSS を施行した159例を対象とした。術後同一プロトコルで治療を行い、採 血は術翌日より 2 日ごとに 9 日目まで行われた。血清 $\mathrm{Na}<135 \mathrm{mEq}$ を低ナトり ウム血症（DHN）と定義した。DHNに至らず、術後5日以隆に術前に比較し て血清 $\mathrm{Na}$ 濃度が3mEq 以上低下したものをナトリウム低下群(LowNa)、それ 以外のものを正常群 (Normal) とした。

【結果】DHNは64例(40\%)、LowNaは42例(26\%)、Normal は53例（44\%）で あった。平均年齢はそれぞれ60.9歳、5 6.6 歳、5 2.1 歳で、DHN群で有意に高齢 であった術翌日に $3 \mathrm{mEq}$ 以上の血清ナトリウム濃度低下が見られた症例がそ れぞれ 23 例(35.9\%)、9例 $(21.4 \%) 、 2$ 例 $(3.7 \%)$ と DHN 群、LowNa群で有意 に多く認められた。

【考察】 OlsonらによるとTSS術後DHN非発症例であっても約 $2 / 3$ の患者に $\mathrm{ADH}$ 調整障害がみとめられたとされており、TSS術後症例では多くの症例 で軽度のSIADH 状態であることが示唆されている。LowNa群はNormal群、 DHN群と中間の患者背景を有しており、LowNa群は軽度のSIADH状態であ る可能性が高い。DHN発生因子として、高齢患者、術翌日血清 $\mathrm{Na}$ 值 $3 \mathrm{mEq}$ 以 上の低下が有意であった。

【結語】TSS術後患者ではDHN発生が見られなくとも潜在的なSIADH症例が 多く存在していることが示された。DHNは起こるべき合併症として十分な対 策が必要である。術翌日の血清 $\mathrm{Na}$ 濃度低下はDHN予測因子と言える。

\section{3-8-3 CRH/GRH/TRH/LHRH四者負荷試験の代替として の GHRP2/TRH/LHRH三者負荷試験の有用性}

鈴木 佐和子 ${ }^{1,2}$ 、類家 裕太郎 ${ }^{1,2}$ 、石渡 一樹 1,2 、内藤 久美子 ${ }^{1,2}$ 、 出口 ハンナ 1,2 、石田 晶子 ${ }^{1,2}$ 、志賀 明菜 ${ }^{1,2}$ 、田村 愛 $^{1,2}$ 、 藤本 真徳 ${ }^{1,2}$ 、小出 尚史 ${ }^{1,2}$ 、横手 幸太郎 ${ }^{1,2}$

${ }^{1}$ 千葉大学医学部附属病院 糖尿病代謝内分泌内科、 ${ }^{2}$ 千葉大学大学院医学研 究院 内分泌代謝·血液・老年内科学

【緒言】Growth hormone-releasing peptide-2 (GHRP2)はGHのみでなく視 床下部一下垂体一副腎(HPA axis)を刺激する。GHRP2 はGH分泌不全の診断 に広く用いられる一方で、視床下部 - 下垂体 - 副腎系（HPA axis）刺激の 分子メカニズムは不明でありどのように臨床応用できるのか報告により異な る。本検討により下垂体ホルモン精查のために広く行われている四者角荷試験 $(\mathrm{CRH}+\mathrm{GRH}+\mathrm{TSH}+\mathrm{LHRH})$ の代替として三者負荷試験 $(\mathrm{GHRP} 2+\mathrm{TSH}+\mathrm{LHRH})$ が有用である可能性が示唆されたので報告する。【方法】過去 5 年間でHPA axisの評価のため当院を受診した 49 名を対象に、GHRP2 試験のHPA axisへの 影響検討し、インスリン低血糖刺激試験（ITT 試験)、CRH負荷試験と比較検 討した。【結果・考察】GHRP2投与後の ACTH、コルチゾールの推移はCRH 投与後と類似しておりITT試験時とは異なっていた。GHRP2負荷後の peak ACTH值はCRH負荷試験と同様に下垂体性副腎不全において正常・視床下部 性副腎不全・副腎性副腎不全のいずれと比較しても有意に低かった。更に中枢 性副腎不全（視床下部性、下垂体性）において GHRP2負荷後の peak ACTH 值は CRH負荷後の peak ACTH值と有意に相関した。GHRP2負荷試験におけ る中枢性副腎不全の診断には、peak ACTH、peak cortisolのcut-off值をそれ ぞれ $20.6 \mathrm{pg} / \mathrm{ml} 、 11.7 \mu \mathrm{g} / \mathrm{dl}$ に設定するのが最も感度特異度が高かった。これ らの結果はGHRP2負荷試験が $\mathrm{GH}$ 分泌不全症の診断のみでなく CRH 負荷試験 と同様に中枢性副腎不全、特に下垂体性副腎不全の診断に有用であることを示 している。

\section{3-8-5 下垂体偶発腫の臨床的特徵における検討 二施設 共同研究}

石井 康大 ${ }^{1,2}$ 、阿部 一朗 ${ }^{3}$ 、亀田 亘 ${ }^{1} 、$ 森永 裕介 ${ }^{4}$ 、伊藤 美以子 ${ }^{5}$ 羽田 幸里香 ${ }^{1}$ 、高瀬 薰、杉本 薰 ${ }^{3}$ 、藤井 秀幸 ${ }^{3}$ 、大石 華子 $^{3} 、$

越智 健太郎 ${ }^{3} 、 山$ 尾 有加 ${ }^{3} 、$ 峯崎 みどり ${ }^{3}$ 、高士 祐一 ${ }^{3} 、$

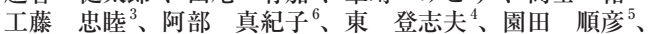
石澤 賢一1、小林 邦久 ${ }^{3}$

${ }^{1}$ 山形大学医学部附属病院 第三内科、 ${ }^{2}$ 公立置賜総合病院 内科、 ${ }^{3}$ 福岡大学筑 紫病院 内分泌・糖尿病内科、帛福岡大学筑紫病院 脳神経外科、 ${ }^{5}$ 山形大学医 学部附属病院 脳神経外科、6 九州大学大学院医学系研究院 予防医学分野

【背景・方法】画像技術の進歩により、下垂体偶発腫(PI)の発見頻度が増加し ているが、詳細な臨床的、内分泌学的検討は少ない。今回我々は、2015年4月 から 2018年3月までに、山形大学医学部附属病院、福岡大学筑紫病院にて、PI の精查を行った65例について検討した。【結果】平均年齢は55.6歳で、男性 は $52.3 \%$ であった。発見契機は、頭痛 $30.8 \%$ 、検診 $15.4 \%$ 、他疾患検査 $13.8 \%$ 、 めまい $12.3 \%$ 、外傷時検查 $10.8 \%$ であった。診断については、非機能性下垂体 腺腫(NFPA)が $50.8 \%$ 、ラトケ囊胞(RCC) が $16.9 \%$ 、機能性下垂体腺腫 (FPA) が $10.8 \%$ 、良性下垂体外腫瘍 (BEPT) が $9.2 \%$ 、悪性腫瘍 (MT) が $12.3 \%$ であっ た。内分泌機能障害に関しては、GH低下が $36.9 \% 、 F S H$ 低下が $33.8 \%$ 、LH低 下が $32.3 \% 、$ TSH低下が $24.6 \%$ ACTH低下が $15.4 \% 、$ PRL低下が $3.1 \% 、 中$ 枢性尿崩症(DI)が4.6\%であった。NFPA群と比較して、MT群で若く(60.1対 37.1 歳)、BMIが低く(22.8対 19.5)、高血圧 (51.5 対 12.5\%) と脂質異常症 (72.7 対 $37.5 \%)$ が少なく、DIの合併が多かった (0対 $25.0 \%)($ 各 $\mathrm{p}<0.05)$ 。更に、NFPA群 は、FPA群、BEPT群、MT群よりも下垂体卒中の合併が有意に多かった(各 < 005 )【考察】PIは臨床的、内分泌学的に様々な特徵を持つため、原則詳組 な精査を行うべきである。今後、大規模の検討を行う必要があると思われた。

\section{3-9-1＼cjkstart褐色細胞腫、パラガングリオーマにおけるインク レチンの解析}

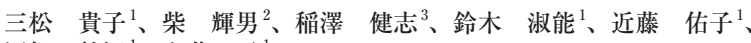
岡畑 純江 ${ }^{1}$ 、上芝 元

東邦大学 医療センター大橋病院、 ${ }^{2}$ 総合東京病院 糖尿病・代謝内科、 ${ }^{3}$ 柏 市立柏市民病院 内分泌・代謝内科

【目的】褐色細胞腫（PPC)、パラガングリオーマ (PGL) のインクレチンに関 連する報告はまだ少ない。今回、PPGLで手術を行った患者の GLP-1、GIPの 変化を評価した【方法】患者は3名、女性、年龄は $426 \pm 238$ 歲いいずれも ノルアドレナリン優位。術前後に75gOGTTを行った。結果】 OGTTの結果 1 名が糖尿病型、2名は正常型であり、術後も不変だった。 HbAlcは6.2\%か ら $5.8 \%$ 、HOMA- $\beta$ 132.2 から 158.6、Insulinogenic index 0.93から 1.08、CP 2.2から 2.3、HOMA-IR 5.8から 3.8、QuickI 0.083から $0.105 （ \mathrm{P}<0.05 ）$ と抵抗 性の改善を認めた。FPGに差は見られず、負荷 30 分後の血糖值が 172.3 から 1537 と有意に改善した $(\mathrm{P}<0.02)$ IRI值は 120 分後において1024から 124.1 と 上昇していた $(\mathrm{P}<0.01)$ 。 GLP-1 は術前基碟值は感度未満から $3.7 \mathrm{pmol} / \mathrm{L}$ 、術 後の基礎値は全員感度未满、糖負荷後の Peak 值は術前 6.0 、術後 5.6 といずれ も既報の健常人より低值であった。 GIP 值は術前基礎値 6.33 、術後 4.47 、糖真 荷後はPGL症例では二相性にGIPが分泌されたが、PPC 2例では15-30分に単 相性のピークが見られたーピーク值は術前45.5から術語462 と変化は見られな かった。【結語】術前術後で血糖值の改善、インスリン抵抗性の改善が見られ たが、インクレチン作用による附糖能障害改善作用は明らかで無かった。負荷 後の GIPの分泌はPPC と PGLで異なるようであった。副腎皮質にはGIP受容 体、副腎髄質にはGLP-1受容体が発現しており、特にPPCではGLP-1受容体 が渦利発現していると報告されている。今回PPCでは副腎の片側摘出が行わ れているため、インクレチン分泌の違いが生じた可能性も考えられた。 


\section{3-9-2 無症候性副腎褐色細胞腫の臨床的検討}

井手 久満、中山 哲成、大坂 晃由、安田 友佳、井上泰之、 岩端 威之、下村 之人、兵頭 洋二、瀬戸口誠、小堀 善友、 德本 直彦、新井 学、宋 成浩、岡田 弘 獨協医科大学埼玉医療センター泌尿器科

近年、健診や画像診断の普及に伴い、副腎偶発腫瘍の発見頻度は増加してい る。無症候性副袩褐色細胞腫は、副腎偶発腫瘍の $5 \%$ を占める。今回、我々は 高血压などの特銜的な臨床症状を伴わず、近医での画像検查などにて偶然登 見された副腎褐色細胞腫の 12 例をまとめたので報告する。年齢の中央值は 56 歳 (33-78)、腫䜾径の中央值は $4.5 \mathrm{~cm}(3-8)$ 、男女比は $1: 1$ であった。血中カテ コールアミンで異常を示したものは、4例(33\%)、蓄尿検查にて異常を示さな いものの MIBG シンチグラフィ、MRIにて褐色細胞腫を疑い手術を施行した 症例が 1 例あった。全症例において腹腔鏡下副腎摘除術が施行され、病理組織 学的に褐色細盷睡の診断々なった。健診等で発見された副㹂偶発腪は、臨床症 状がなくても、サブクリニカルクッシング症候群、無症候性褐色細胞腫、原発 性アルドステロン症、悪性腫瘍、転移性腫瘍等の評価が必要となる。画像にて 無症候性の褐色細胞腫が疑われる場合には、内分泌学的検查掞よび手術の検討 は十分になされるべきと考えられた。

\section{3-9-4 本邦の先天性リポイド副腎過形成症の有病率と病 型別臨床像の解明}

石井 智弘 1,7 、鹿島田 健一 2,7 、棚橋 祐典 3.7 、向井 德男 4,7 、 田島 敏広 ${ }^{5,7}$ 、勝又 規行 ${ }^{6,7}$ 、長谷川 奉延 ${ }^{1,7}$

${ }^{1}$ 慶應義塾大学 小児科、 ${ }^{2}$ 東京医科歯科大学 小児科、 ${ }^{3}$ 旭川医科大学 小児科、 旭川赤十字病院 小児科、息治医科大学とちぎ子ども医療センター 小児科、 ${ }^{6}$ 成育医療研究センター研究所 分子内分泌研究部、 7 厚生労働科学研究費補 助金難治性疾患等政策研究事業 副腎ホルモン産生異常に関する調査研究

【背景】先天性リポイド副腎過形成症（LCAH）は副腎と性腺のステロイド產 生不全とコレステロール蓄積を来す疾患である。病型別の臨床像を詳細に検討 した報告は過去にない

【目的】本邦LCAHの有病率と病型別臨床像の確立。

【方法】本学会と日本小児内分泌学会の評議員を対象に、2017年12月時点で 【方法】本学会と日本小児内分泌学会の評議員を対象に、2017年 12 月 フォロー中の症例を収集し(一次調查)、臨床情報を解析した(二次調查)。
【結果】一次調査 : 153 施設から答を得て、有病率を 2.1 人 100 万人 $(95 \% \mathrm{CI}$ 1.9-2.4) と算出した。

二次調查：古典型 41 例 $[79 \%$ (XY 群 27 例、XX群 14 例)]、非古典型 11 例 $[21 \%$ (XY群 3 例、XX群 8 例)] 解析した。診断時年齔は古典型 $[0.1(0.2)$ 歳、以下平 均 $(\mathrm{SD})$ で表示]に比し非古典型[4.3 (2.4) 歳]で有意に高かった $(\mathrm{P}<0.01)$ 。古典 型XY群では、全例で外性器女性型がみられ、精巣摘出、エストロゲン (E) 補充 を要した。古典型XX群では、90\%で乳房発育と初経がみられたが、12歳以降 の $64 \%$ でE補充を要した。非古典型XY群では、全例で外性器男性型がみられ、 思春期は自然発来し、成人期もアンドロゲン補充は不要であった。非古典型 XX群では、古典型に比し思春期開始時期[11.2(0.9) 歳 vs 9.6(0.5)歳]が有意に遅 かった $(\mathrm{P}=0.02)$ が、全例で初経がみられ、成人期も $\mathrm{E}$ 補充は不要であった。 12 歳以降の古典型XX群 $27 \%$ 、非古典型XX群 $14 \%$ で卵巣囊腫に手術を要した 【結論】LCAHの有病率は 2.1 人/100万人と推定され、非古典型が約 $20 \%$ 占め た。2歳以上の副腎不全発症ないし男性型外性器を持つ場合に非古典型と定義 た。2歳以上の副腎不全発症な

\section{3-9-6 CYP17A1 遺伝子p.R347C木モ接合体変異による $17 \alpha$ 水酸化酵素欠損症 : 高齢で診断された一例}

山形 聡 ${ }^{1} 、$ 臼井 健 ${ }^{2}$ 、齋藤 洸平 ${ }^{2}$ 、高安 忍 ${ }^{1} 、$ 臼谷 真理 ${ }^{1} 、$

照井 健 ${ }^{1}$ 、蒢山 和則 ${ }^{1}$ 、大門 黃 ${ }^{1}$

${ }^{1}$ 弘前大学医学部附属病院 内分泌内科 - 糖尿病代謝内科、 ${ }^{2}$ 静岡県立総合病 院 リサーチサポートセンター

【症例】67歳女性 (46XX)【既往】甲状腺乳頭癌【現病歴・現症】原発性了 ルドステロン症疑い（レニン活性 $0.6 \mathrm{ng} / \mathrm{mL} / \mathrm{hr}$ 、アルドステロン (PAC) 16.7 $\mathrm{ng} / \mathrm{dL}$ ）として当科入院。カプトプリル試験は陰性。12年前から偶発的に両 側副腎腫大は指摘されていたが精査されていなかった。性毛は欠如。月経は あったが妊娠出産歴はない。【検查】 ACTH $114 \mathrm{pg} / \mathrm{mL}$ 、cortisol (F) $11 \mathrm{~g}$ / dLからクッシング症候群の合併が疑われた。0.5 mgデキサメサゾン抑制試 験ではF 5.3 と抑制されず、深夜 F は 7.6 と高值。ところが $\mathrm{CRH}$ 試験で $\mathrm{ACTH}$ $53 \rightarrow 213 、 F ~ 8.9 \rightarrow 9.7$ (無反応) と副腎不全が疑われた。迅速 $\mathrm{ACTH}$ 試験で

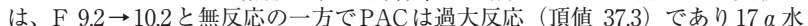
酸化酵素欠損症を疑った。ACTH負荷後のデオキシコルチコステロン、コル チコステロンは各々 $0.26 \rightarrow 1.19 \mathrm{ng} / \mathrm{mL} 、 28.4 \rightarrow 199 \mathrm{ng} / \mathrm{mL}$ と過㮃反応を示し た。17ヒドロキシプレグネノロン、11デオキシコルチゾール及び尿中遊離コ ルチゾールは基準範囲内だった。ダイレクトシークエンスでCYP17A1 遺伝子 にp.R347Cの病的バリアントが認められ、MLPA解析でへミ接合体は否定され た。両親はいとこ婚であった。【考察】本例は知り得る限り最高齢の $17 a$ 水酸 化酵素欠損症である。さらにp.R347C 変異の既報は片側アレルが久失したへミ 接合体であるが、ホモ接合体変異の初報告となる。副腎不全症状を呈すること がなく、臨床内分泌学的検査結果からも P 450c17活性低下は部分的なものと推 察され、67歳まで診断に至らなかった教育的症例として報告する。

\section{3-9-3 当院で経験したMIBG scan陰性の褐色細胞腫・パ ラガンブリオーマ6例の検討}

井上 祥花 ${ }^{1} 、$ 井上 愛子 ${ }^{1} 、$ 伊藤 慶彦 ${ }^{1}$ 、浜松 圭太 ${ }^{2}$ 岡崎 恭子 ${ }^{1} 、$ 西澤 衡 1 、村部 浩之 ${ }^{1}$ 、横田 敏彦

${ }^{1}$ 倉敷中央病院 内分泌代謝・リウマチ内科、 ${ }^{2}$ 京都大学大学院医学研究科 糖 尿病・内分泌・栄養内科学

【緒言】褐色細胞腫・パラガングリオーマ(PPGL)の機能的・局在診断におい て、I-123 meta-iodobenzylguanidine シンチグラフィ (MIBG scan)が有用とさ れている。MIBG scanは疾患特異性が高い一方で、約 $10 \%$ で偽陰性を呈する ことが報告されている。【方法】2007年 9 月から 2019 年11月までに、当院で組 織学的にPPGLと診断されMIBG scan陰性だった症例について検討した。【結 果】組織学的に診断された41例のうち、MIBG scan㓌性例は6例であった。 副腎褐色細胞腫が 4 例、膀胱パラガングリオーマが 2 例で、年齢中央值 52.5 歳 (36〜70歳)、男女比は $1: 1$ であった。尿中ノルメタネフリンのみ高值が 2 例、 尿中メタネフリンのみ高值が 2 例、いずれも正常域が 2 例であり、カテコール アミン産生能としては低い症例が多かった。また、腫瘍径は中央值 $15 \mathrm{~mm}(11$ 〜 40mm) と比較的小さい段階で診断された症例が多かった。副腎褐色細胞腫 の4例でFDG-PET/CTが撮像され、全例で病変部位への集皘を認めた。病理 学的に悪性を示唆された症例や、術後再発を認めた症例はなかった。【考察】 本検討ではMIBG scan 陰性の症例は6例 $(14.6 \%)$ ) 既報と比較しやや高頻度で あった。MIBG scanは空間分解能が低いため小さなPPGLが見落とされる可 能性が指摘されているが、SPECTの導入により高精度の評価が可能になった。 また、膀胱パラガングリオーマの場合は、尿中に排浀されるI-123が同定を奶 げる可能性が考えられる。近年、MIBG scan 陰性の褐色細胞腫に対する FDGPET/CTの有效性を示した報告があるが、本検討でも撮像した全例で陽性を 呈し、診断の一助になると考えられる。

\section{3-9-5 21 水酸化酥素欠損症の治療指標である早朝尿中プレ グナントリオールと早朝血中17OHPは正相関する}

系永 知代 ${ }^{1,3}$ 、井澤 雅子 ${ }^{2}$ 、濱島 崇 ${ }^{2}$ 、長谷川 行洋

${ }^{1}$ 東京都立小児総合医療センター内分泌・代謝科、 ${ }^{2}$ あいち小坚保健医療総 合センター 内分泌代謝科、 ${ }^{3}$ 大分大学 医学部 小児科

【背景】 21 水酸化酵素欠損症（21OHD）の治療に扔ける生化学的指標には、 $17 \mathrm{OHP}$ とその尿中代謝産物であるプレグナントリオール (PT) がある。我々は 先行研究で、早朝尿PTを後方視的に解析し、骨年齢、身長・体重増加からみた 治療良好群の早朝尿PTの 10-90\%ileは0.56-6.0 mg/gCrであった (Izawa M et al. 2008)。これまでに早朝尿PT と血中 $17 \mathrm{OHP}$ を直接比較した報告はなく、血 中17OHPの最適な採血のタイミングについての検討はされてこなかった。

【目的】早朝尿PT と血中 $17 \mathrm{OHP}$ (早朝内服前、朝の内服 2 時間後、 4 時間後そ れぞれ）を直接比較し、早朝尿 PT と最も相関する17OHPの採血の夕イミング について検討する

【方法】対象は3-25歳の $210 H D$ 患者25例。研究期間は3 日間で、朝内服前に 採取した尿でPT值を測定した $(0 \mathrm{~h}-\mathrm{PT})$ 。血液は早朝内服前、内服 2 時間後と 4 時間後に瀘紙に採取し、全血17OHP值（抽出ELISA法）を測定した（それ ぞ れ0h-17OHP、2h-17OHP、4h-17OHP)。0h-PT と0h-17OHP、2h-17OHP、 $4 \mathrm{~h}-17 \mathrm{OHP}$ との相関の有無をそれぞれ評価した。

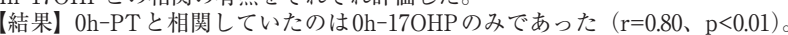
早朝尿 PT 0.56-6.0 mg/gCrに相当する $0 \mathrm{~h}-17 \mathrm{OHP} の$ 範囲を回㷌式より換算する と全血值 3.4-42 ng/ml、血清值（ELISA 法） 9.7-74 ng/ml、(LC-MS/MS 法) $5.7-56 \mathrm{ng} / \mathrm{ml}$ だった

【考察】0h-17OHPは0h-PT と相関しており、換算で得られた範囲は治療指標 となる可能性がある。しかし、採取の容易さや測定費用の点から、早朝血中 17OHP 測定よりも早朝尿PTの方が汎用性が高いと考える。

【結論】21OHDの治療指標である早朝尿中PT と早朝血中 $17 \mathrm{OHP}$ は正相関する。 